TE AO HURIHURI

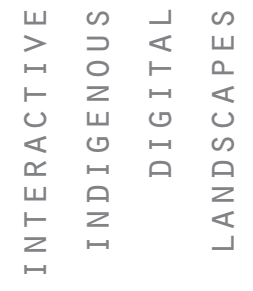

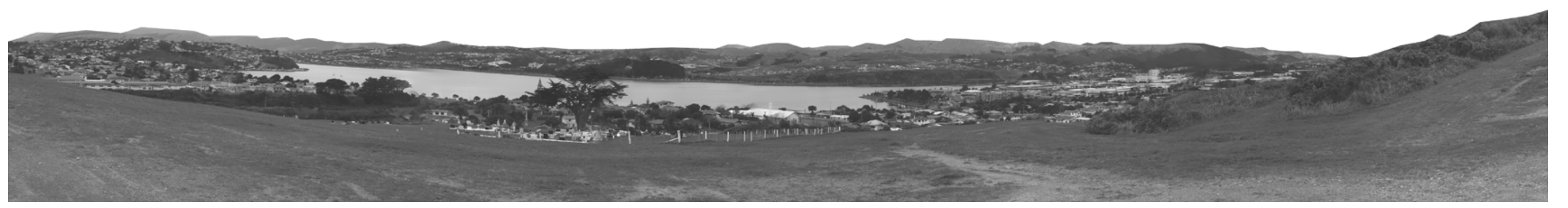




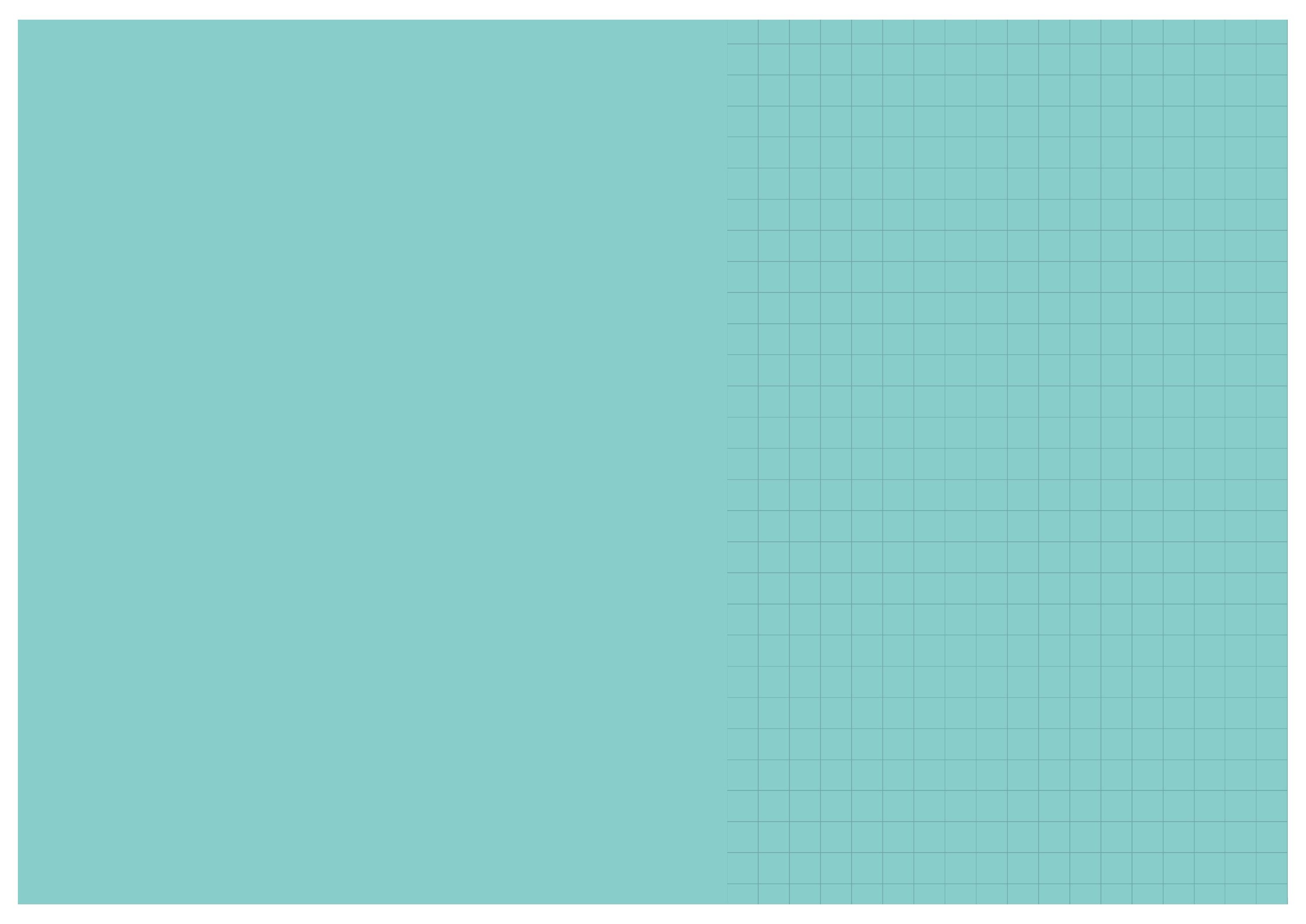




\section{TE AO HURIHURI}

INTERACT I VE INDIGENOUS

DIGITAL LANDSCAPES

TAKAPUWAHIA, PORIRUA

Ko Maungaroa toku maunga Ko kereru toku awa

Ko te Whanau-ā-Apanui toku iwi Ko Kaiaio te Tangata

Ko Whiting te ingoa o toku whanau Ko Dean rāua ko Maria ōku matua Ko Kimi taku tuahine

Nō Te Whanganui-a-Tara ia matou Ko Tamatamaarangi taku ingoa

PEPEHA 
Fig 1. Annual Temperature Porirua (Authors own)

'CLIMATE IS ECOLOGY'

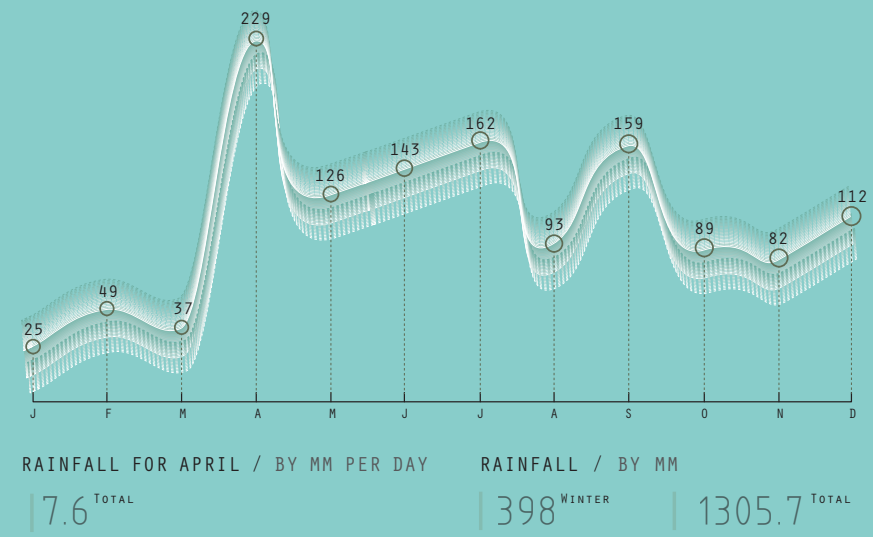

Fig 2. Annual Rainfall Porirua (Authors own)

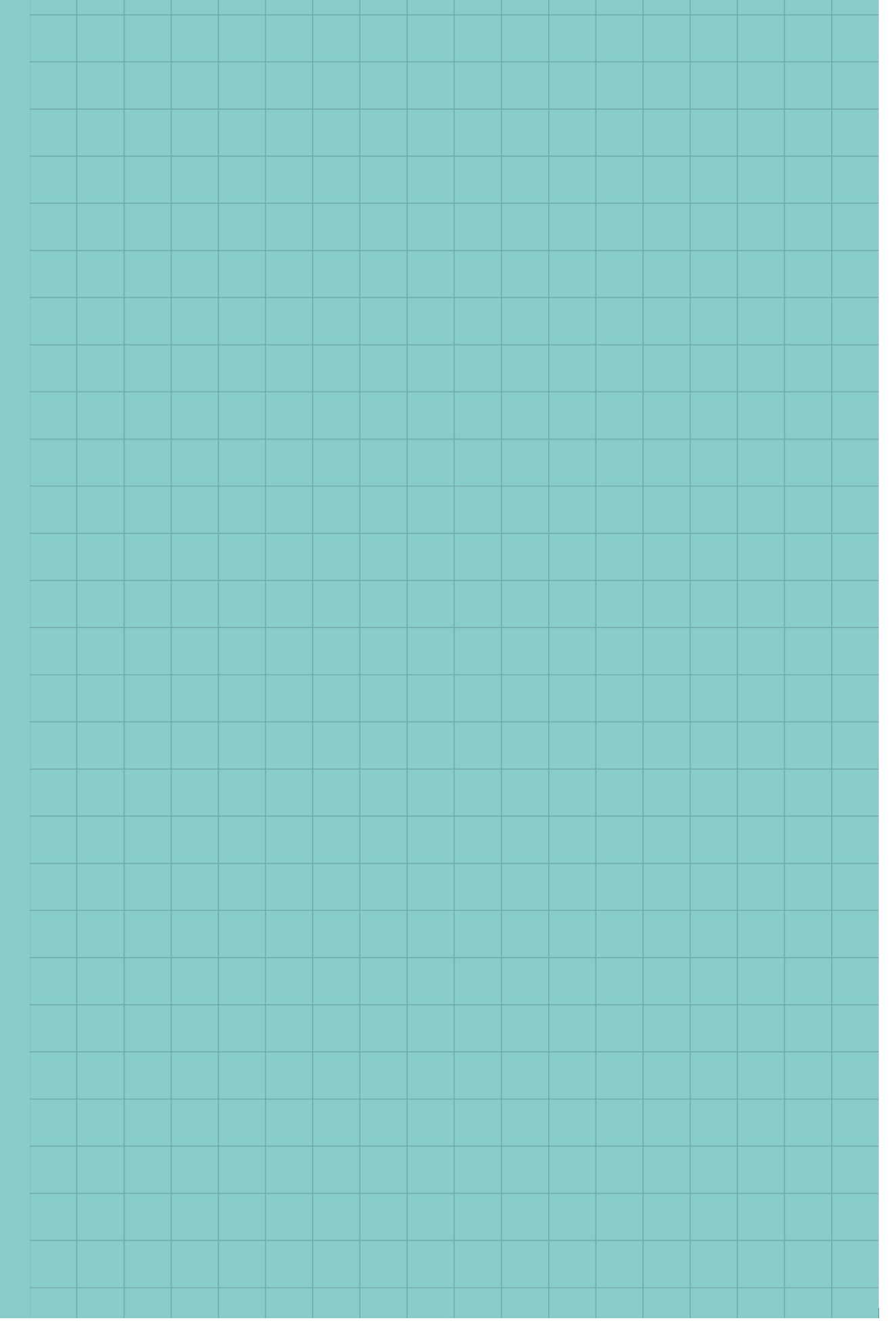




\section{ABSTRACT}

At the heart of the thesis is the establishment of a new type of landscape practice based upon leveraging the power and potential of computational tools to serve cultural attitudes to land and land management. The research acknowledges that a new approach to landscape understanding is required one that extends the current discipline's mode of notation and representation/visualisation and 'experience' within the design process. It questions current forms of mapping and representational media and highlights limitations when communicating 'non-traditional' cartographic data, such as cultural and spiritual sites arguing that there are opportunities for a more holistic experiential interaction.

By utilising a holistic approach influenced by key Māori kaupapa including kaitiakitanga, manaakitanga, and mauri, the research offers up a novel digital methodology that draws from a range of existing data (demographics, climate etc.) and initiates the creation or capturing of new data.
This extended method of 'bottom up' data collection combined with virtual 3D modelling and visualisation enables traditional understandings of landscape to extend to the experiential in the creation of an immersive, interactive and open collaborative 3D environment. This is further investigated through a process consisting of data conversion to mesh production for game engine use, incorporating diverse data sets to create new knowledge landscapes - an information-rich land model which in turn generates interactive 3D landscapes for end users.

The process itself uses commonplace photogrammetry techniques as a means to capture selected areas of the cultural landscape recording both mesh and texture/image map. We then employ the software 'Unreal Engine 4' (Game development platform). The development of the gamification model allows location specific data to be 'plugged in' for landscape ecosystem monitoring also providing the potential for real time resource management.
Future speculation of the cultural landscape enables climate events to be simulated and tested, giving an understanding of implications and risks with a view to local response and mitigation. From a design perspective the method/model allows designers to respond effectively with Māori end users and their real needs, potentially collapsing traditional modes of engagement and consultation between designer-client relationships providing a more bottom up collaborative approach. 


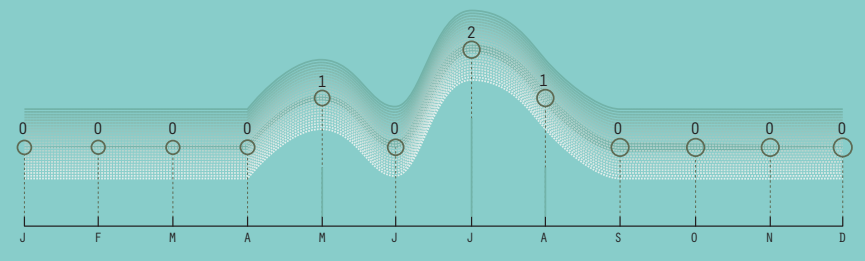

GALE DAYS JULY / BY PERCENTAGE

$6.5^{\text {PERCEN }}$

Fig 3. Annual Gale Days Porirua

(Authors own)

\section{'CLIMATE IS ECOLOgy'}

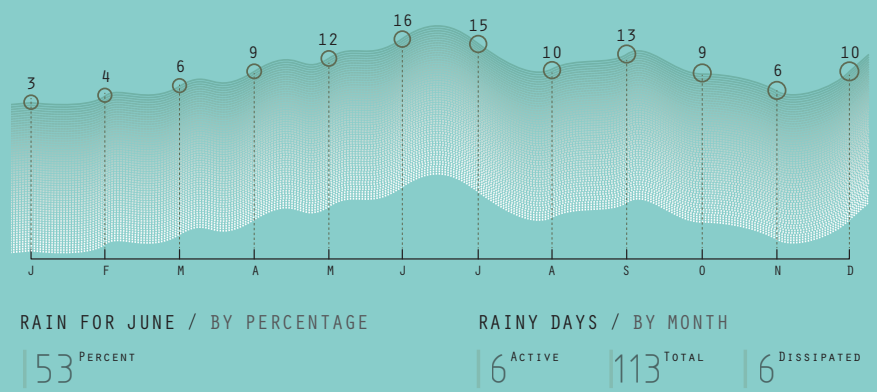

$53^{\text {PERC }}$

Fig 4. Annual Rain Days Porirua

(Authors own)
GALE DAYS / BY DAYS

\begin{tabular}{l|l|l}
$1^{\text {Min inum }}$ & $4^{\text {TotaL }}$ & $2^{\text {Maximun }}$
\end{tabular}

$113^{\text {TOTAL }} 6^{\text {Diss PAPAED }}$

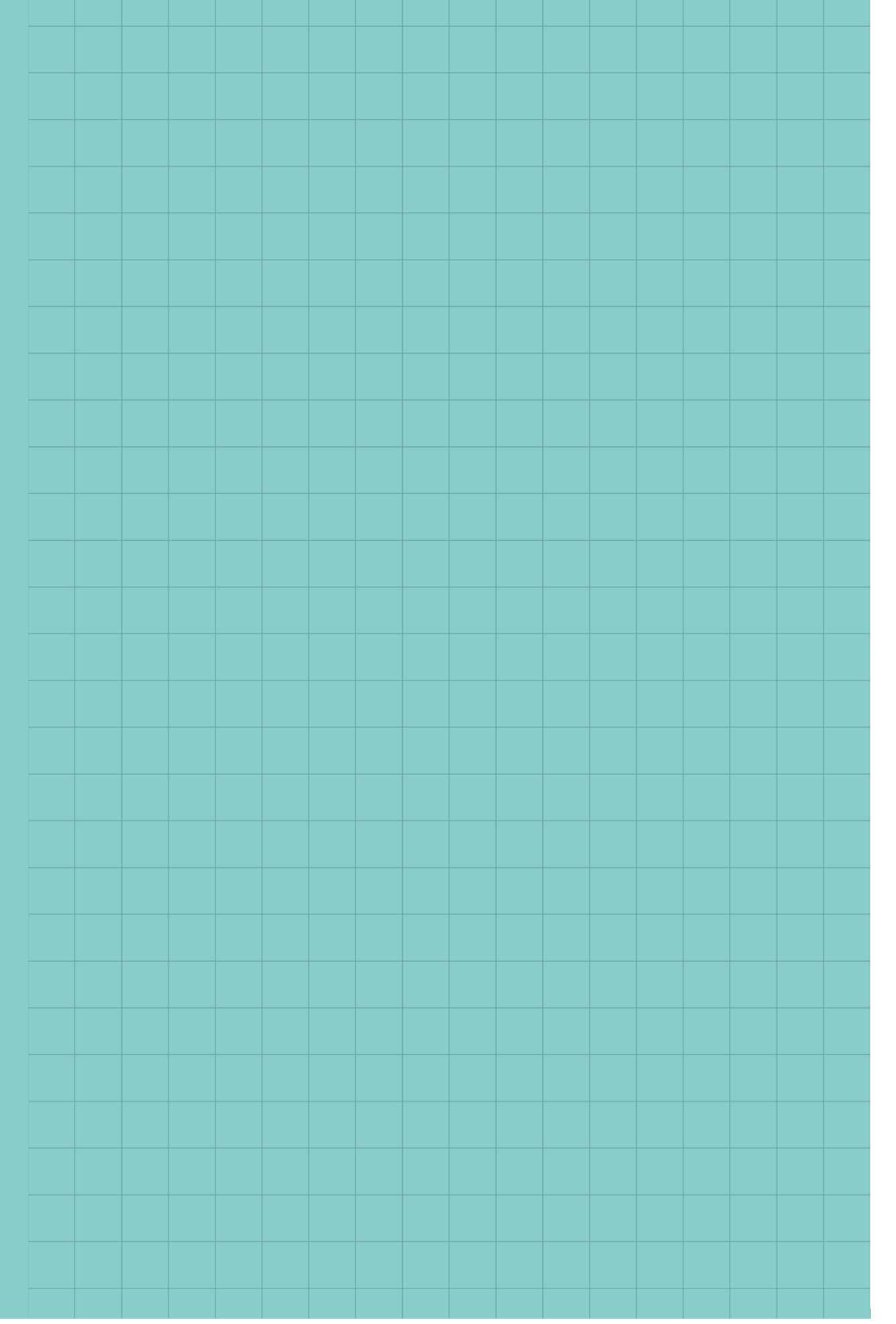




\section{CONTENTS}

\section{ACKNOWLEDGEMENTS}

This research would not have been possible without the assistance and guidance of many individuals. Firstly I would like to thank the iwi we have been working with Ngāti Toa Rangatira, the sharing of knowledge and for allowing access

to your landholdings was greatly appreciated. Also thanks to Derek Kawiti and Martin Bryant for your supervision. A special mention to Mum, Dad and Kimi, I am grateful for your support and encouragement during my time at university and glad that it my studies have finally come to an end.
Abstract

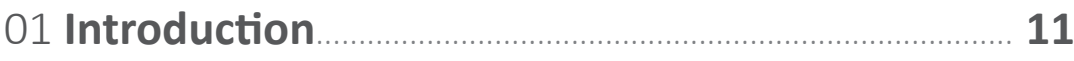

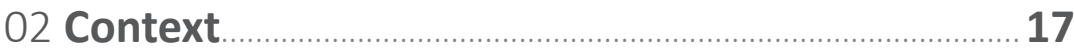

03 Literature Review.............................................................. 29

04 Methodology 37

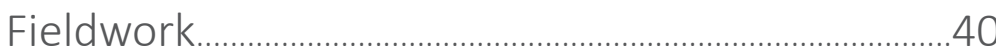

Interactive Digital Landscape System..........................46

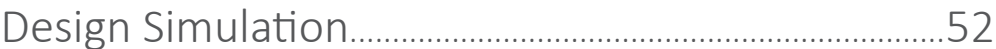

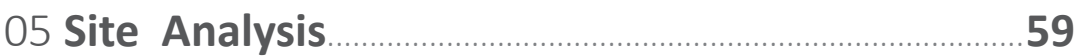

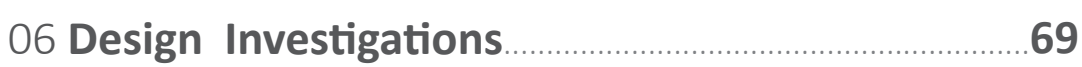

07 Design Response ……………………………………………........85

08 Discussion + Conclusion $\ldots$

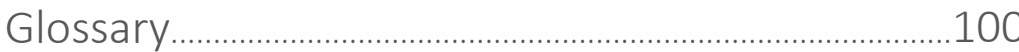

List of Figures................................................................................. 101

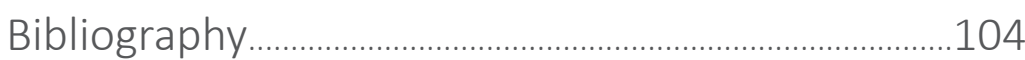

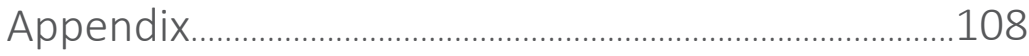




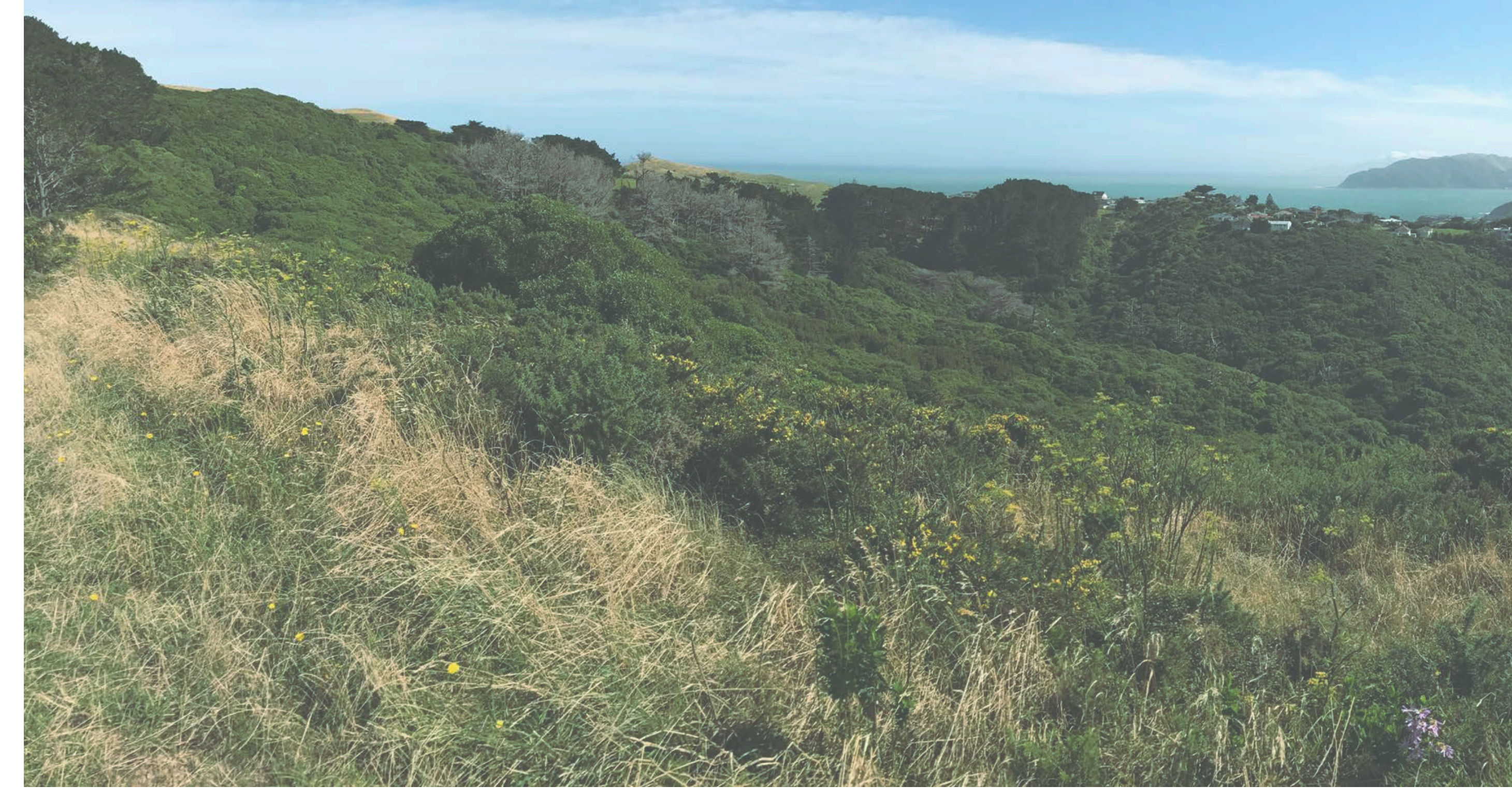




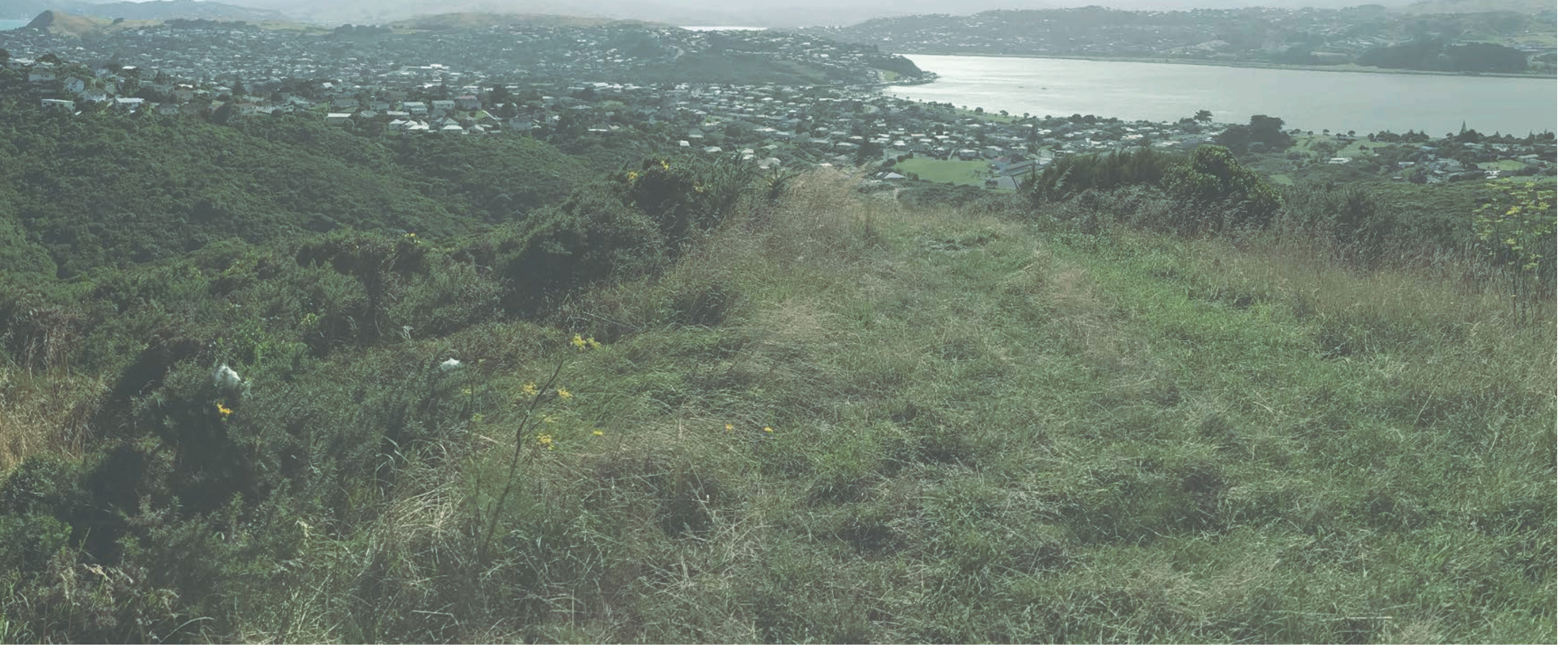


01

INTRODUCTION 


\section{INTRODUCTION}

Landscape architecture is still finding its way as a multidimensional practice in a design environment that has in the past privileged specialist disciplinary expertise. Performance and representation methods within the landscape architecture profession have experienced a steady separation over the last three decades, 'representation' is commonly seen as the domain of the architect/designer, and environmental and civil engineers the discipline of choice for testing design 'performance' through tools such as physical modelling such as wind tunnels or hydrological models.
By reintegrating both of these methods into the monodisciplinary field of landscape architecture, the potential for designers is expansive. Ian McHarg's book "Design with Nature" was forward thinking and included a documented study in the 1960's and 1970's that integrated both representation and performance aspects as being tools for architects. His work covers diverse physiographic regions that are detailed with $2 \mathrm{D}$ overlays summarising patterns of topography, geology, soils, hydrology, vegetation, and current land use giving the designer potential site uses deemed suitable for particular locations. "...data are of little use until they are interpreted and evaluated" (McHarg, 1995, p. 105).
This element of integration between representation and performance methods now have the potential to be revived in landscape architecture as we move towards a more 'topological' 3D understanding of space and information. With more software capable of modelling existing landforms and the fluid dynamics of wind, water, tides, heat, humidity and pollution, the potential for landscape architects, community groups and landowners to explore new dynamic opportunities for embedding temporality and change in the landscape is rapidly improving. Landscape simulations with real time data offer techniques for introducing an evidencebased metric into the design processes, heightening the performative ambitions of spaces and providing quantitative and qualitative arguments that can prove the value of cultural landscapes, remediation projects and enhanced infrastructure. 

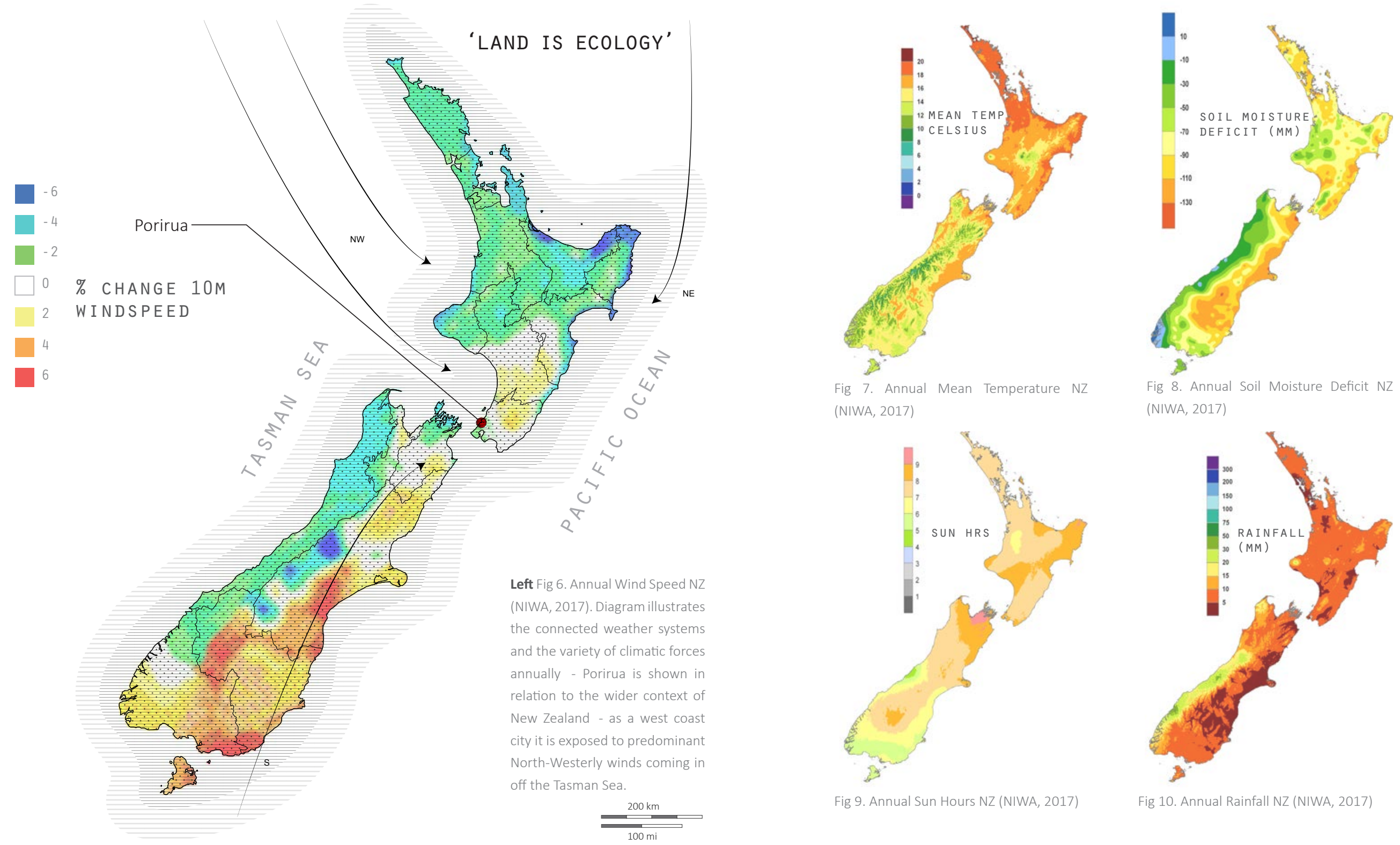

Fig 7. Annual Mean Temperature NZ (NIWA, 2017)

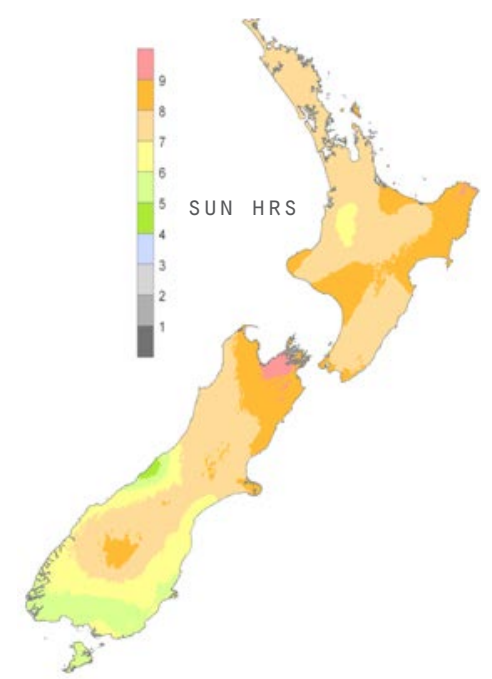

Fig 8. Annual Soil Moisture Deficit NZ (NIWA, 2017)

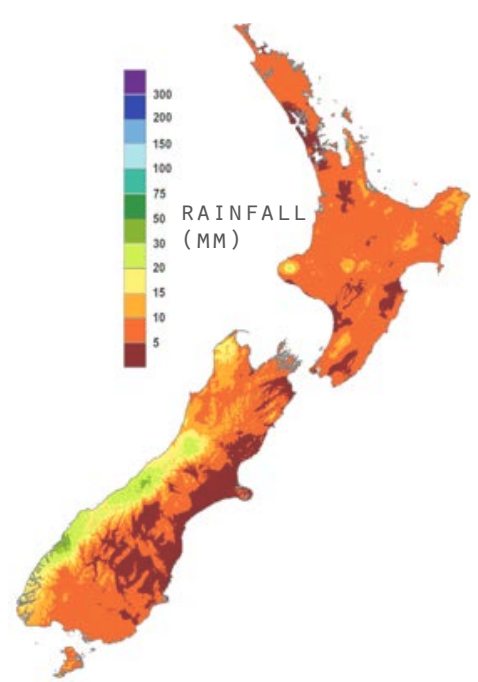

Fig 9. Annual Sun Hours NZ (NIWA, 2017)

Fig 10. Annual Rainfall NZ (NIWA, 2017) 


\section{RESEARCH QUESTION}

How can digital tools be used as a collaboration tool between indigenous groups and designers to test and manage future developments of their land holdings?

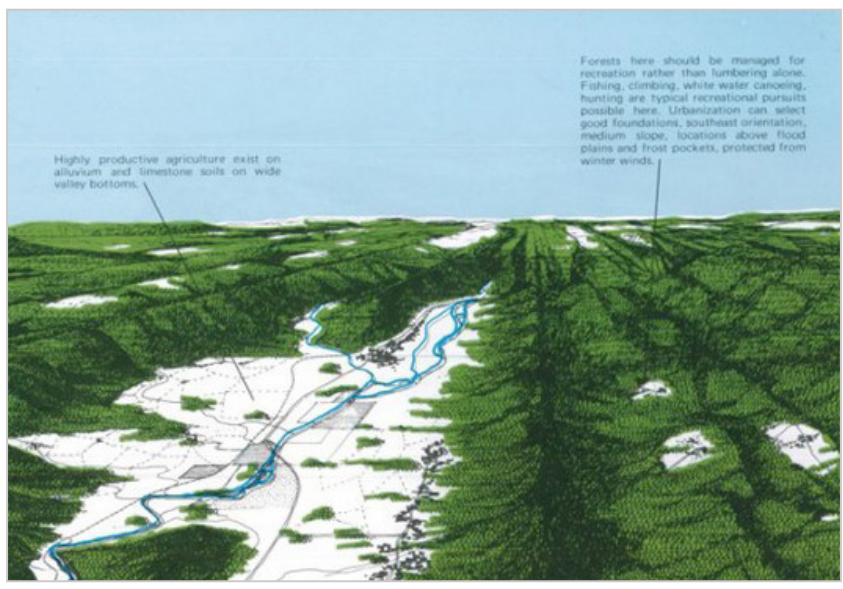

Fig 11. Aerial Perspective (McHarg 1995)

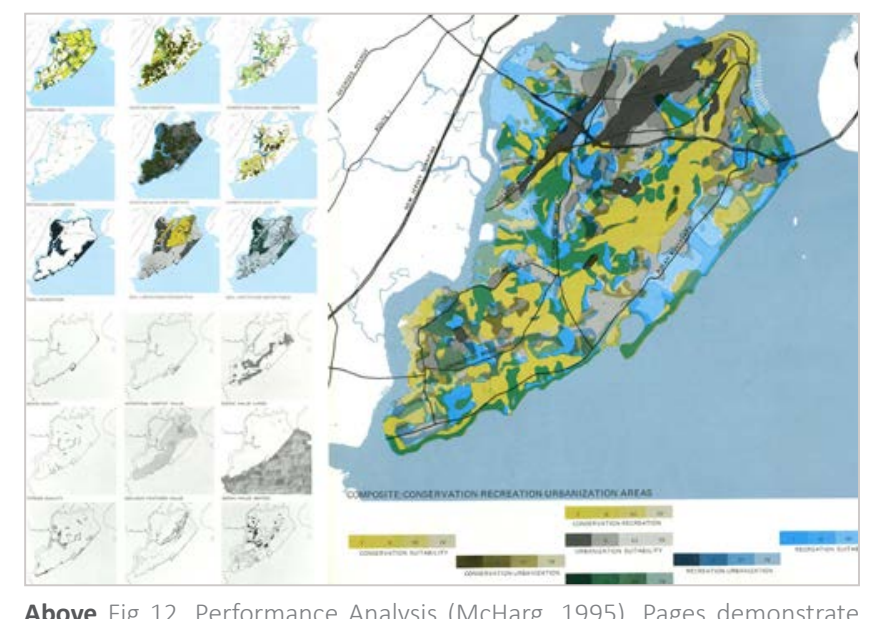

Above Fig 12. Performance Analysis (McHarg, 1995). Pages demonstrate some of the different visual techniques for documenting performance studies of landscapes. 


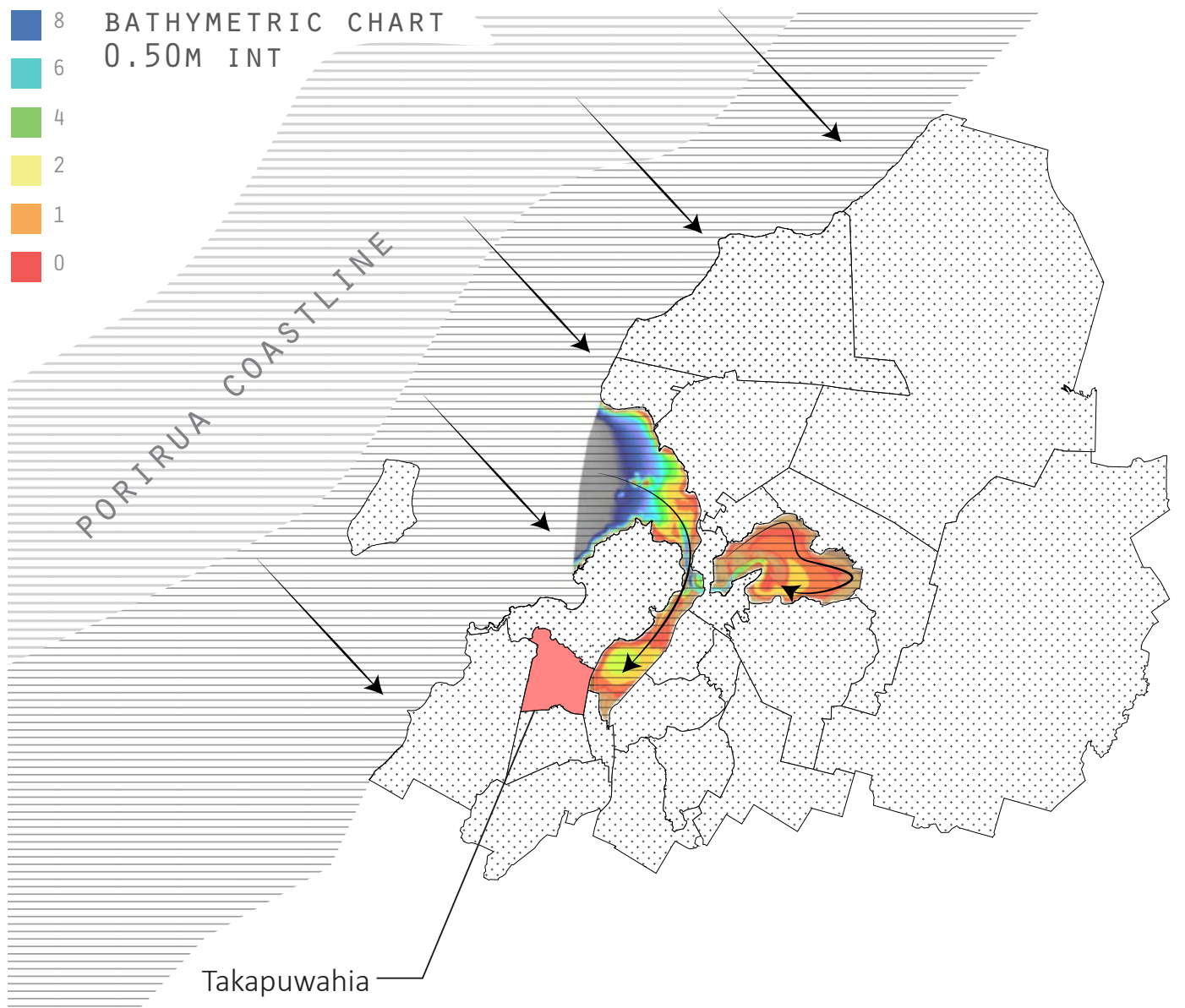

Above Fig 13. Bathymetric Diagram Porirua (Authors own). Diagram

illustrates the location of the intended research site and how submerged terrain is leveled in the surrounding harbour - Takapuwahia is one of the most central suburbs adjacent to the Porirua city center. It receives NorthWesterly winds from over the ridgeline and North-Easterly sea breezes from within the harbour.
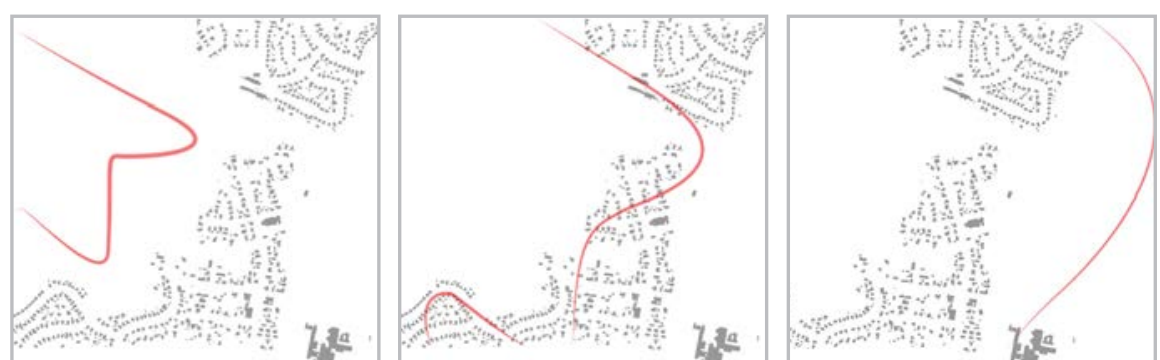

HIGH WINDS
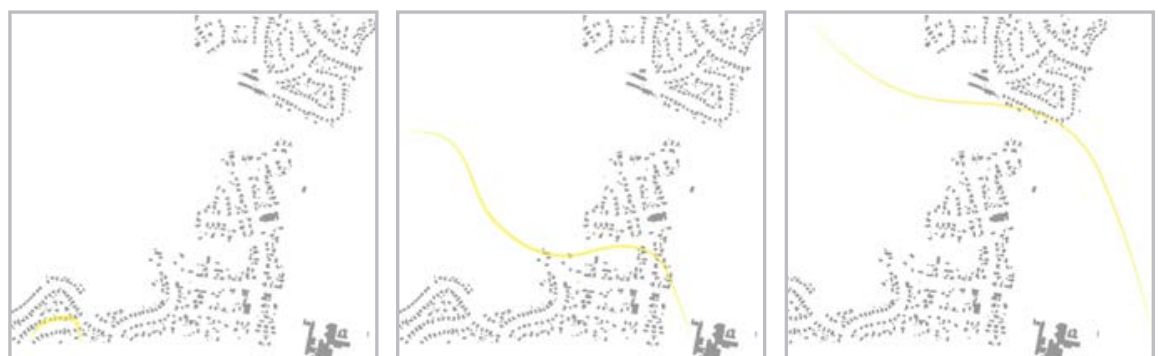

MEDIUM WINDS
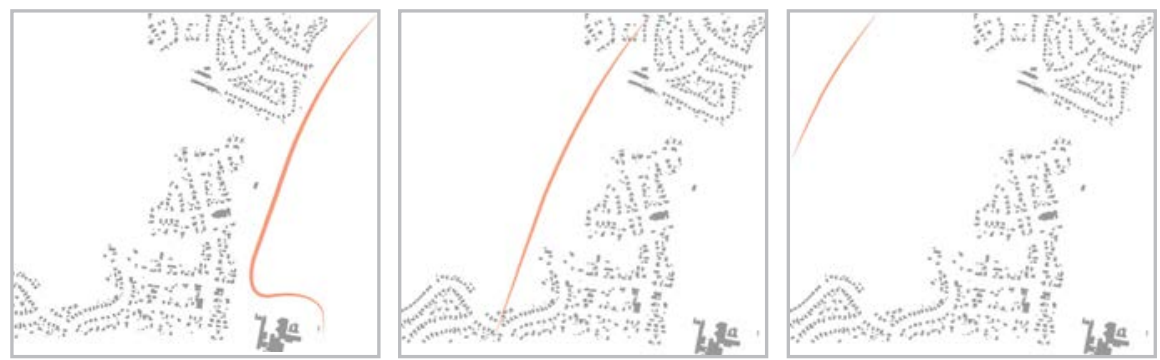

LOW WINDS

Above Fig 14. Plain Windflow Projections (Authors own). Collection of diagrams illustrate the most common wind patterns to hit Takapuwahia these were used in basic model simulations to see how they interacted with features of the site. 


\section{SCOPE}

This thesis proposes the design of a novel method of data capture initiated from a 'bottom up' (crowdsourced) approach which is then supported by a virtual experientia design model. The research focuses on land surveying, scenario planning, and landscape design for a particular indigenous group. The objectives were to select emerging tools and associated processes that operate best in terms of

\section{a) Collaborative engagement}

b) Simulation accuracy

c) Scenario planning

d) Limiting factors
Following these studies, ideal tools and processes are recommended for further research, tool development and testing. Surveying tools explored include: Photogrammetry and GPS locating. Landscape tools include: parametric design and scripting (Rhino \& Grasshopper). Planning tools included: 3D game engine: Unreal Engine 4.

Following the introduction is a brief section on virtual information modelling (VIM) and some of the issues surrounding indigenous landscapes. The methodology section explains how the research was carried out and the design section summarises some of the key findings, results, and recommendations. Following is a brief discussion on future directions and collaboration. The research then finishes with a conclusion on why the research was carried out and how it could be useful for other indigenous groups around the world.

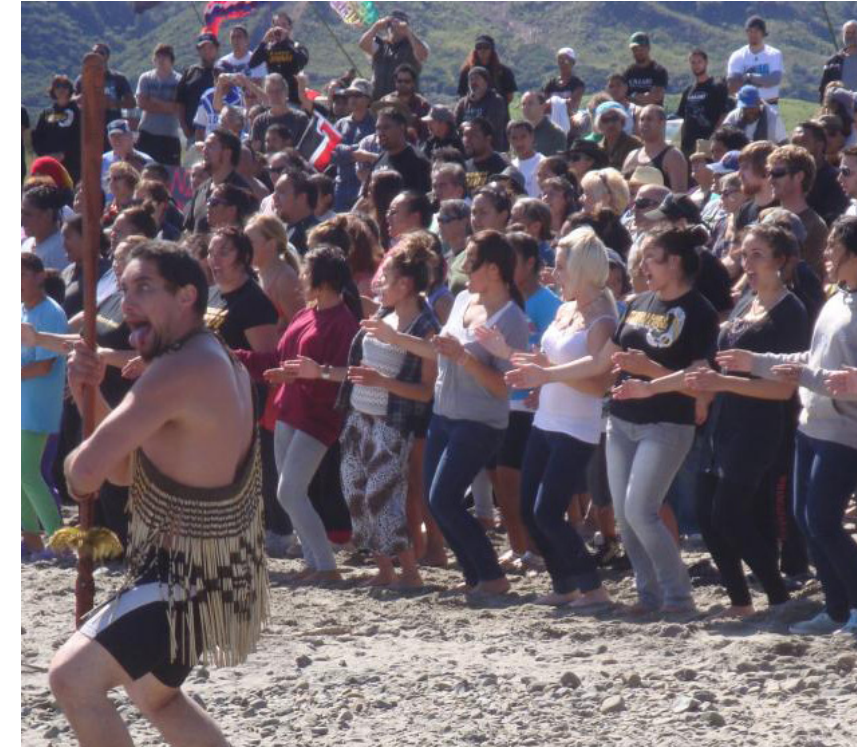

Above Fig 15. Action Against Oil Drilling Intensifies (Aotearoa Independen Media Centre, 2011). Te Whanau-a-Apanui tribe protest against Brazilian oi giant, Petrobras, who were granted premission by the government to rights to deep sea drill off their coast. 


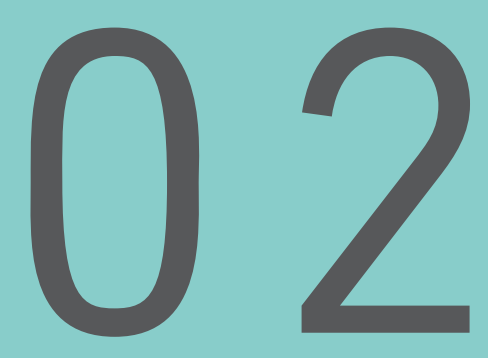

CONTEXT

This section looks at porirua in the context of the greater wellington area.

It draws comparisons between both council and iwi priorities for the porirua area. 


\section{LOCATION}

Takapūwāhia Pā (historically referred to as Porirua Pā or Takapūwāhia Settlement /Township) is situated at the Southern Arm of Te Awarua-o-Porirua Harbour on the south-western shore. The general area is referred to as Takapuwāhia and includes the built area surrounding the Takapūwāhia Marae complex (shown) and the western ridgeline. Mana College and Elsdon Park are located the northern end of the plan site. The marae and residential area is situated mainly on flat land, and in the lower slopes of the Western Hills. These hills have large areas of native bush and provide a scenic backdrop to the community. The foreshore area extends to the south from the Hukatai Stream at Takapūwāhia Reserve to Semple Street.

In 2006 the population for the Takapūwāhia-Elsdon area was recorded at 2268 people, occupying 720 dwellings. While Māori are still the most common ethnic group at $48.8 \%$, there are a number of European, Pacific Island, and Asian families that are also part of the community. The average household size is for the suburb is 3.2 people (Takapūwāhia Community Strategy, 2014).

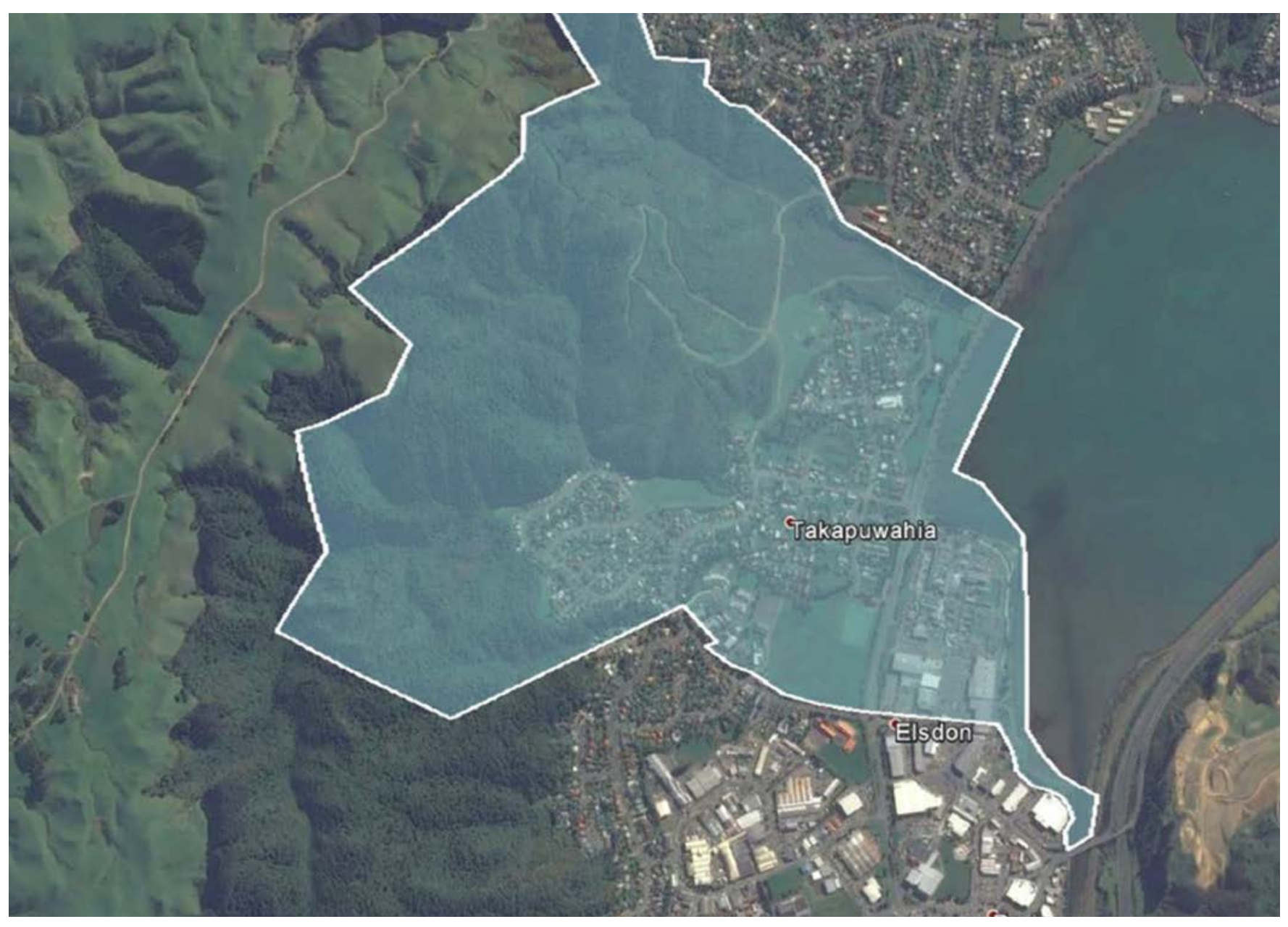

Above Fig 16. Takapuwāhia Boundary (Authors own). Diagram illustrates the suburb of Takapuwahia. As shown it with the white outline it encompasses the entire waterfront property for Porirua's city center. Refer to appendix for street names. 


\section{PORIRUA HARBOUR}

The lands, harbours and waterways, within the Ngāti Toa Rangatira rohe were adversely impacted by European settlement and later urban development. The Porirua and Pauatahanui harbours of Te Awarua o Porirua have high cultural and historical significance to Ngāti Toa Rangatira and contained important natural resources that supported abundant flora and fauna (Takapūwāhia Community Strategy, 2014). The importance of the harbour further increased as Ngāti Toa Rangatira lands diminished following the large scale land purchases in the nineteenth century and Takapūwāhia became the main focus of settlement (Rangatira, Treaty Information- Overview of Ngāti Toa Claims, 2010).

The tribe valued the harbours specifically because it was the rich fisheries and related resources that could be found south of Kāwhia. (Rangatira, Deed of Settlement of Historical Claims Treaty of Waitangi Settlement, 2012). This resource has since declined due to years of neglect and effluent runoff.

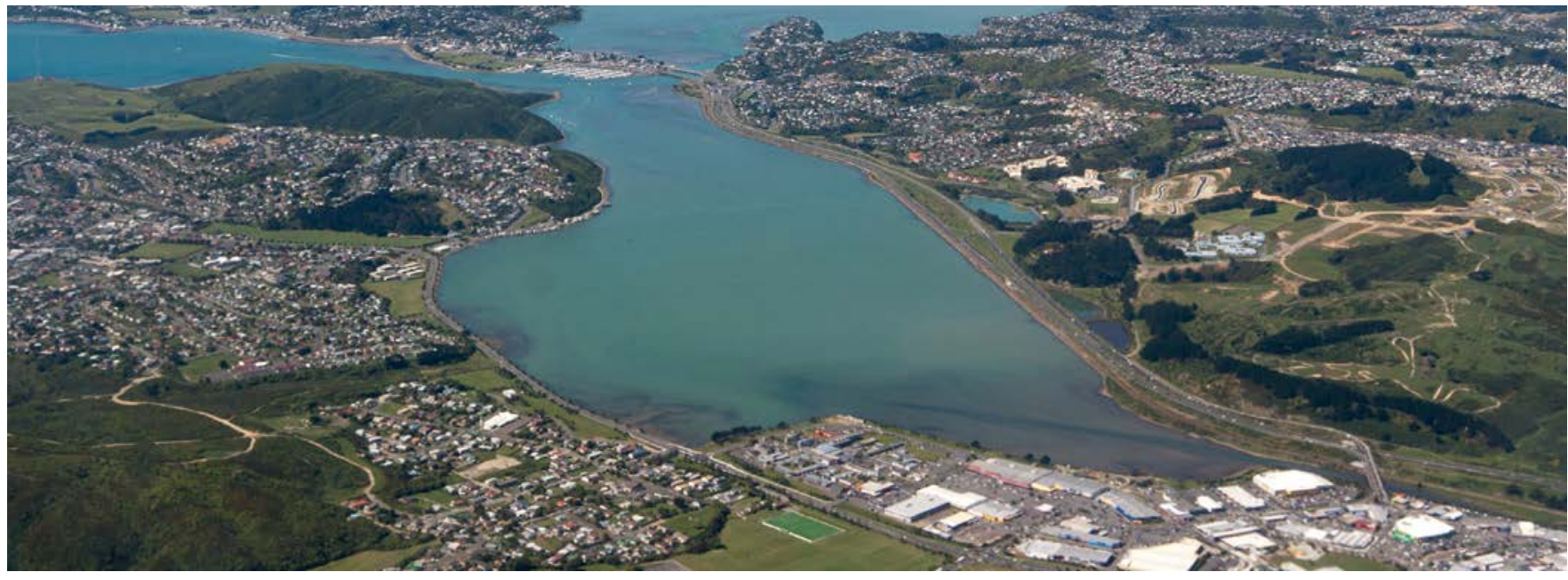

Above Fig 17. Porirua Harbour (Wojtas, 2009). Photograph shows Porirua

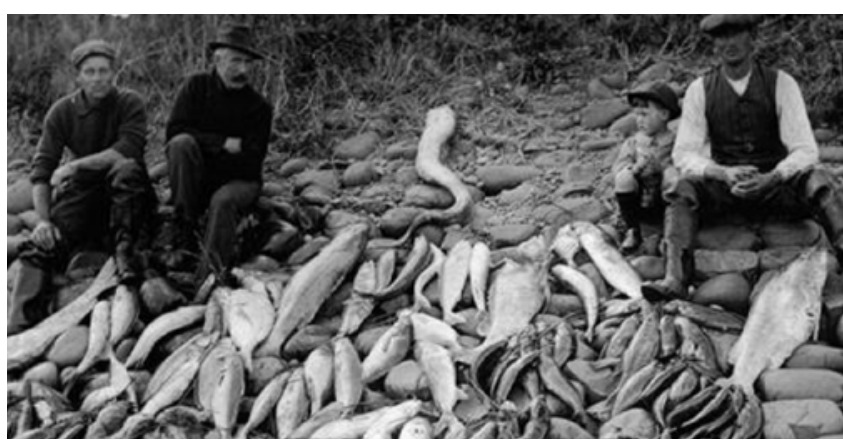

harbour within the center of all suburbs.

Above Fig 18. Historic Catch (Takapūwāhia Community Strategy 2014, Page

9). Photograph of a historic fish catch at Te Awarua o Porirua Harbour. 


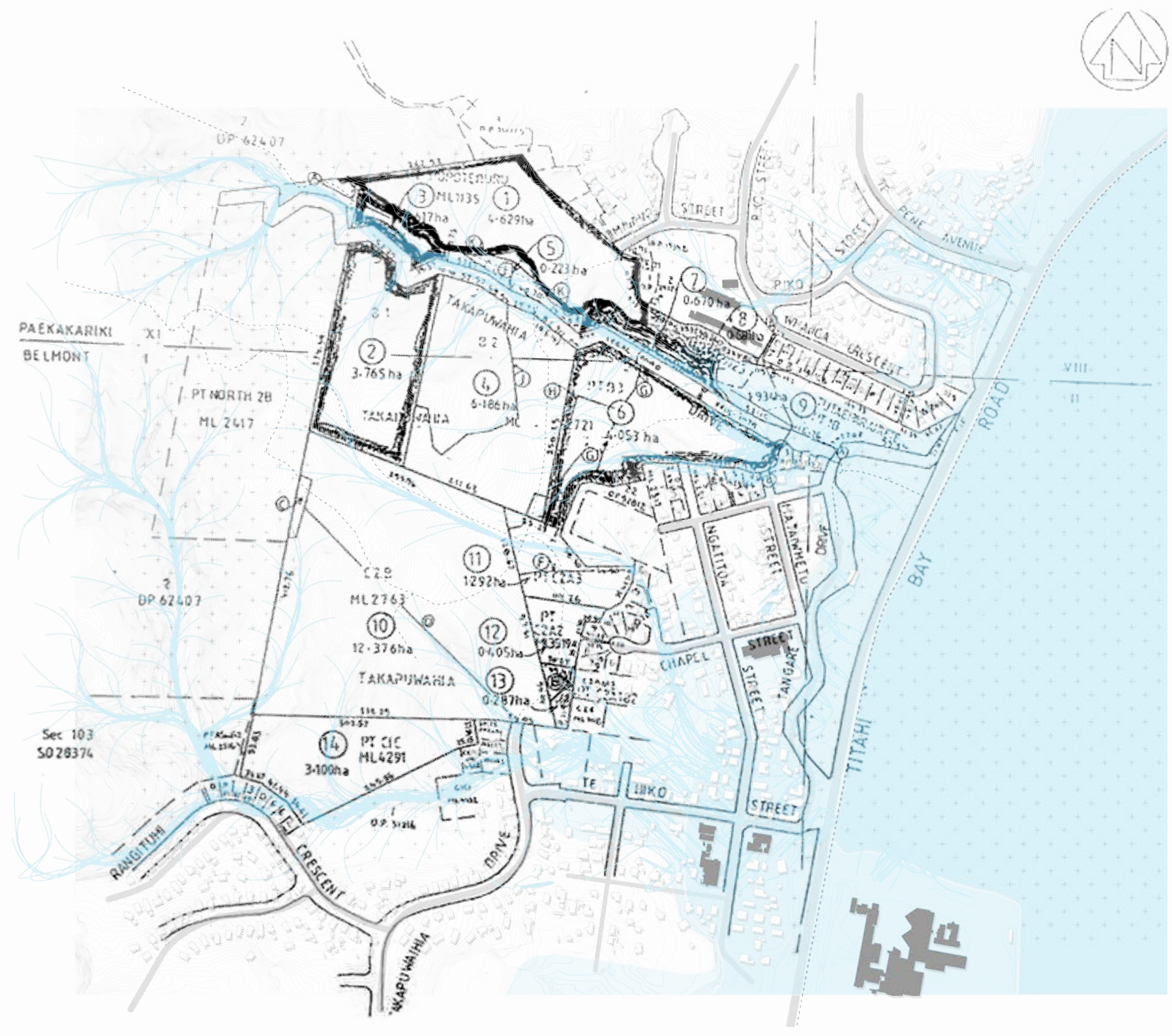

Left Fig 19. Historic Water Simulation (Authors own). Diagram illustrates some of the water systems at play such as flooding, tsunami and rainfal overlayed onto a historic plan of Takapuwahia. Areas outlined with numbers are lots owned by Ngāti Toa today. 


\section{HISTORY}

Ngāti Toa Rangatira are manawhenua Iwi for the Porirua region. At the turn of the 19th century a number of Tainu tribes became embroiled in prolonged inter-tribal conflict (Pōmare, 2005). As tensions escalated, Ngāti Toa Rangatira departed Kāwhia in 1820s and migrated south under the direction of Te Rauparaha and other prominent Ngāti Toa leaders of the time (Pōmare, 2005). Through conquest they reached as far south as Christchurch and Arahura River on the west coast of the South Island (Pōmare, 2005). Their settlement consolidated more to the top of the South Island and the Wellington region through to the Kapiti coast. The name Takapūwāhia is taken from an early settlement at Kāwhia and was embodied into their new home.
In the 1850s the village of Takapūwāhia had a population of 252 who had abandoned their main pā at Taupo (now Plimmerton) and Pukerua. Besides houses, the pā included two raupo chapels, a flour mill powered by water, and 80 acres of intensive farming of including potatoes, maize wheat and kumara (PCC, Historic site: Takapuwahia Village). In 1889 the Urukahika pā in central Porirua, was abandoned and Takapūwāhia became the primary home for the tribe.
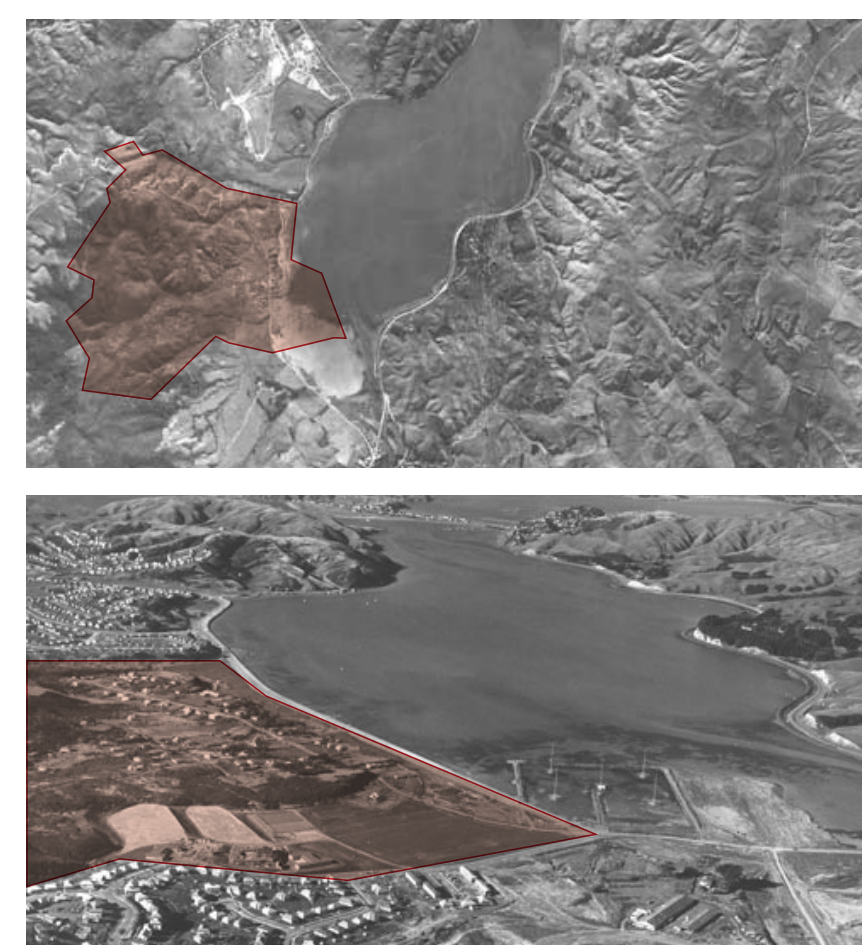

Above Fig 20. Ngāti Toa Rangatira c.1944 Aerial, c.1954 Perspective (Pataka Museum Collection). 


\section{COMMUNITY}

Ngāti Toa Rangatira have identified three main problem

areas that need investigation:

1. The lack of access to land based information.

2. The quality, diversity and sustainability of land management resources.

3. The complexities of indigenous collaboration to address future developments.

Goals:

- Accessibility of Kaitiaki database for Ngāti Toa Rangatira.

- Whanau contribution and interaction.

- Crowdsourcing (recording data themselves).

- Virtual testing of land development.

- Test future built environments.

\section{Outcomes:}

- Ability to see the feasibility of design for Iwi. - Case study for other Iwi, viable tool for other iwi.

- Preserve heritage, degradation of land etc.

- Reuse collected water for Takapūwāhia's personal use. - Manage water treatment.

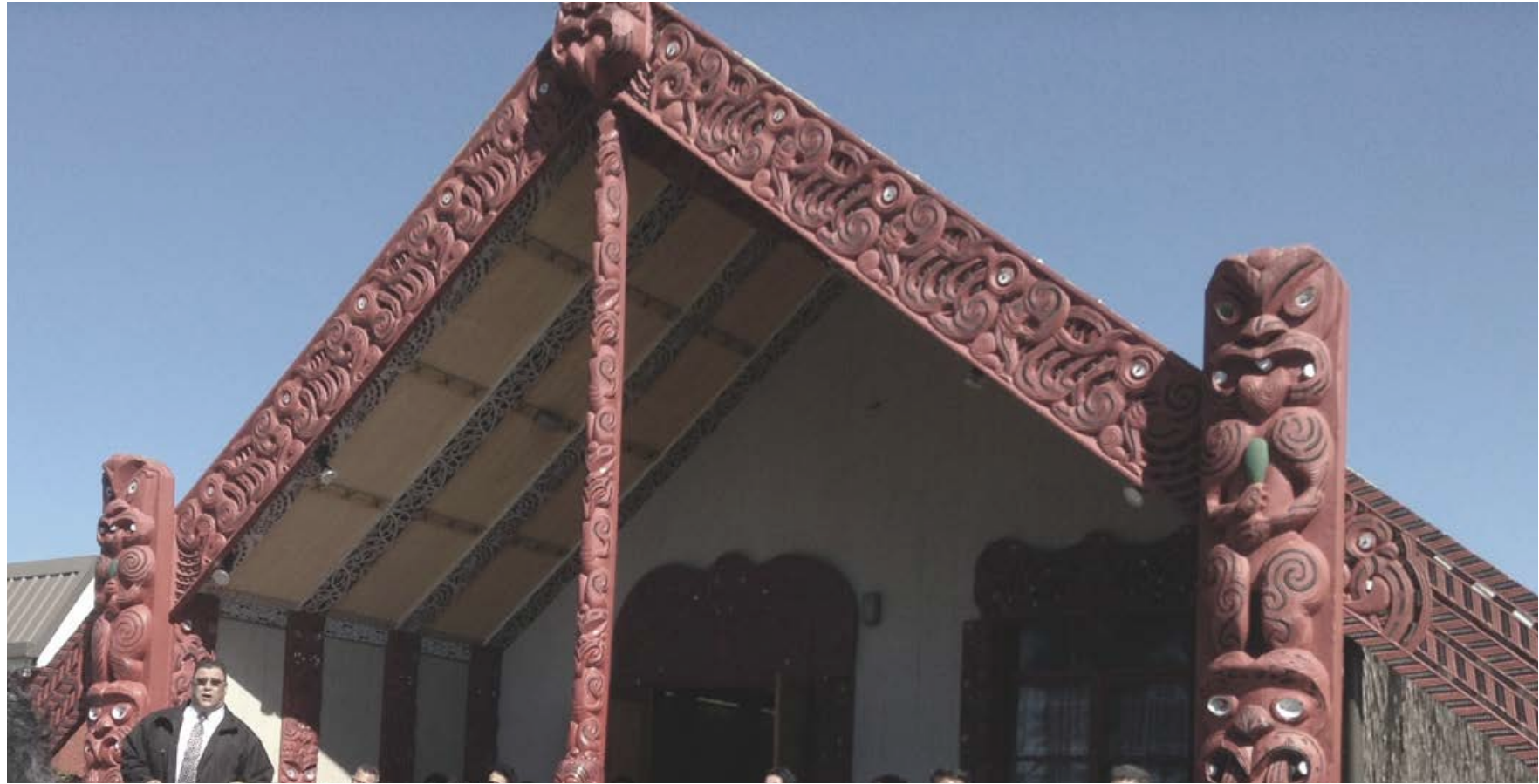

Above Fig 22. Takapūwāhia Marae (Aboriginal Health Tour, 2013). Photograph of the carvings that represent the genealogy and stories of their people. Left Fig 21. Maori at Takapuwahia village, c1909 (Pataka Museum Collection).

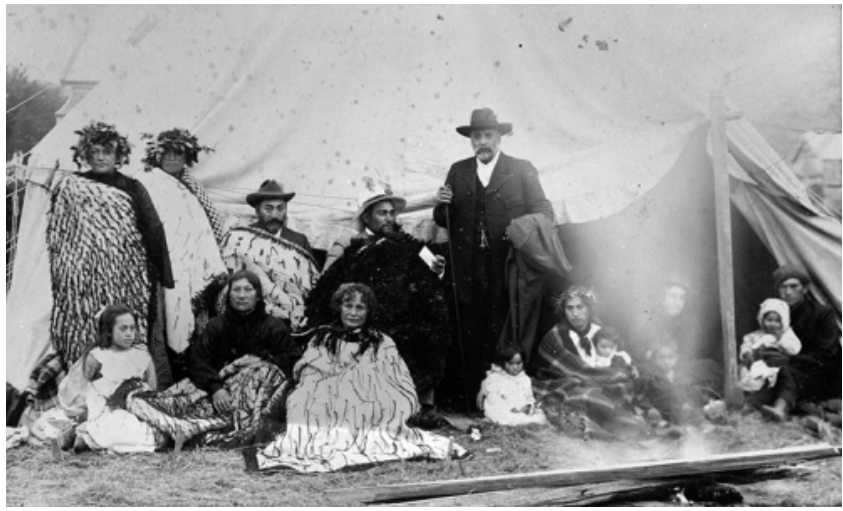




\section{IWI HOUSING}

Housing is an urgent issue for Ngāti Toa Rangatira as other Wellington based iwi (Te Puni Kōkiri, 2016). The tribe has clear goals and objectives they want to apply to the Wellington housing market. These are summarised as:

Promoting and nurturing a healthy, safe and caring environment

- Environmental Management

- Health

- Housing and Land

Maximise opportunities for the economic development of the Iwi and Iwi members

- Treaty claim settlement

- Working with local government

- Developing economic opportunities

Rebuild estates and assets of tangata whenua - Complete the Treaty settlement

- Protect customary interests

Grow Rūnanga services, capacity and assets

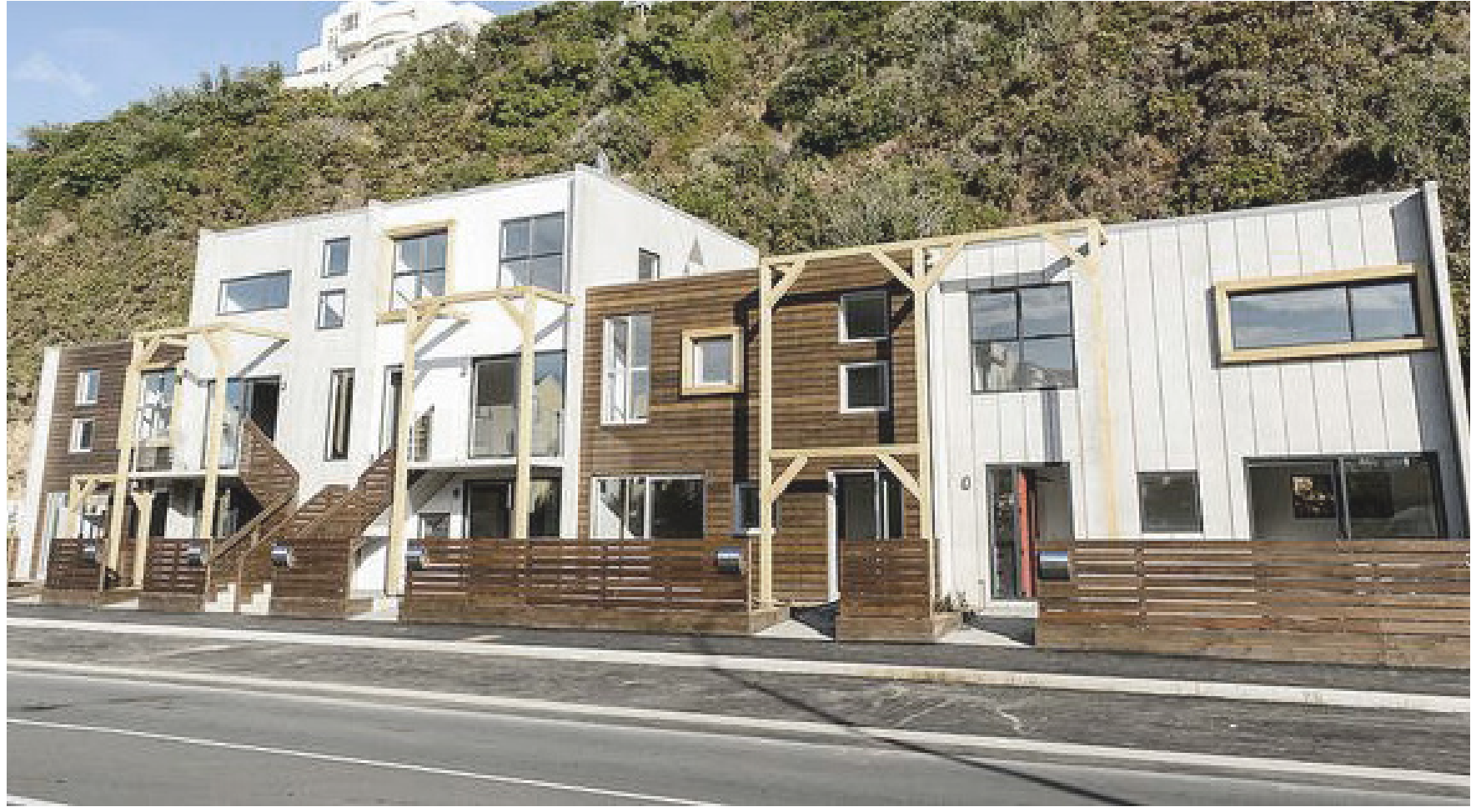

Above Fig 24. Te Aro Pā (Coster, 2016). Photograph of Wellington's first urban papakāinga development - made up of 14 new homes with 10 three bedroom apartments and four single bedroom disability properties.

Left Fig 23. Te Aro Pā Sketch (Winter, 2015). Artist's impression of a new low-cost rental housing development for local iwi to be built on the site of the sheepskin warehouse in Evans Bay. 


\section{AMENITY ZONING}

The development of resource management practice in the Porirua region offers opportunities to foster strong relationships between community and council. By enabling local people to capture and monitor environmental data a detailed picture of the resource can be made. This allows for a more informed management process, where plans can be actioned and results monitored, realising the potential of an area and improving its desirability.

Right Fig 25. Wellington Residential Median Sale Prices (Westpac, 2013). Diagram illustrates the locations of the more desirable suburbs in the Wellington region - prices have begun to soar in areas where there are good schools, shops, public transport and access to a variety of amenities.

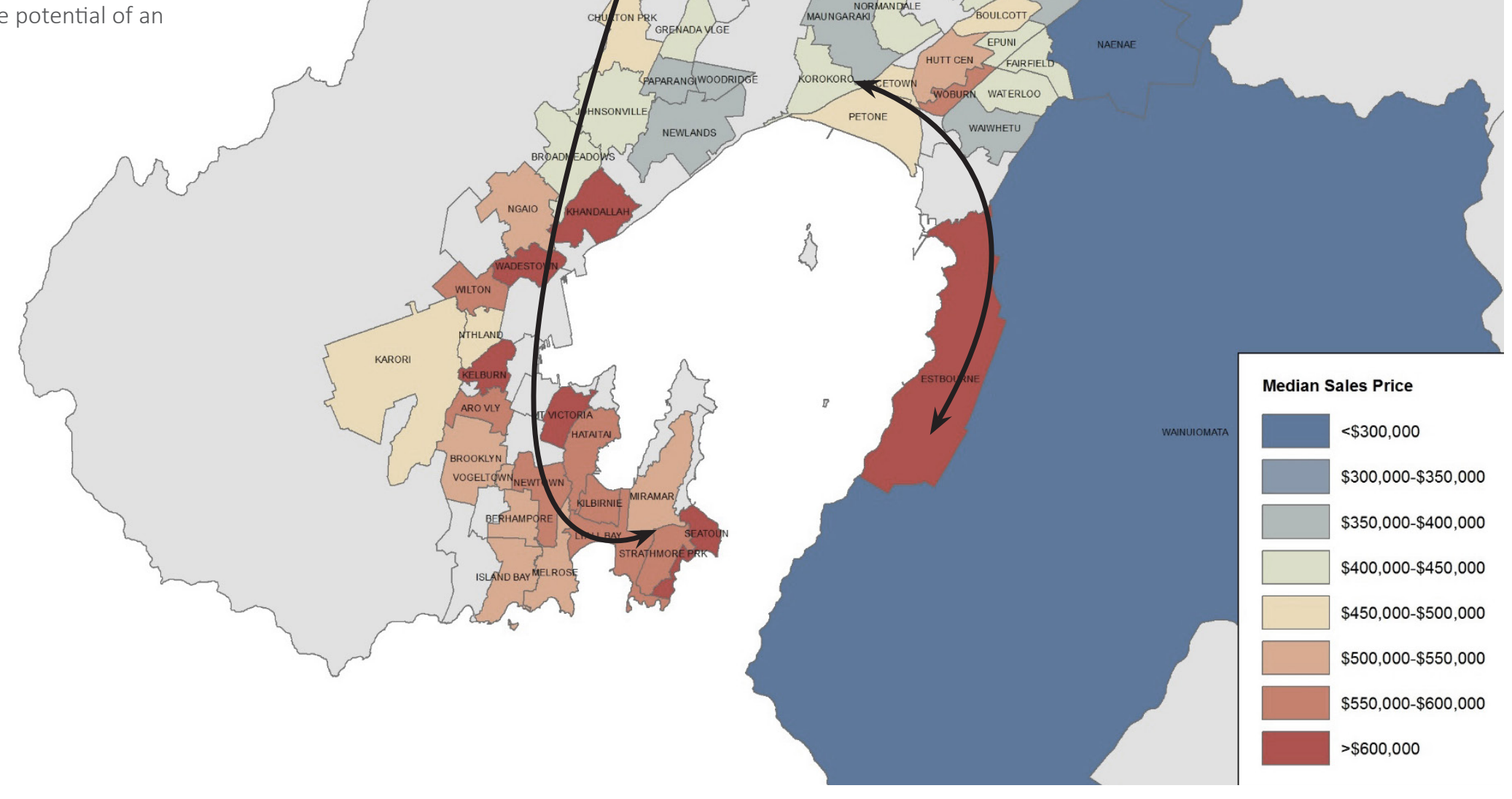




\section{URBAN HOUSING}

Ngāti Toa Rangatira are at the lower end of the inventory scale located in areas that are not actively sought after. They would like to develop more housing for their own iwi members and see a growing market of other first home buyers which could benefit Iwi in their economic and social outcomes. The areas identified for potential housing have degraded environmentally and need improvements in order for development to proceed. The impacts of increased waste, cars, water and sound through a new development can have major implications on the local ecology need to be addressed in the design and a management phases. The Iwi have expressed interest in becoming more actively engaged with this research to gain some insight into what could be done.

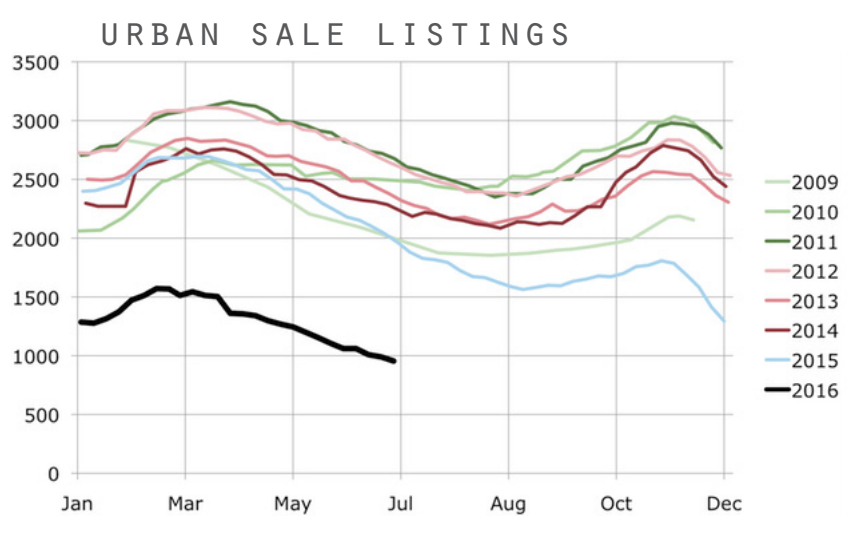

Above Fig 26. Urban Sale Listings (Wellington Rental Market Analysis, 2016). Sale Listings in Wellington's urban area are at an all time low with under 1000 listings compared to a normal level of 2000 the previous years.

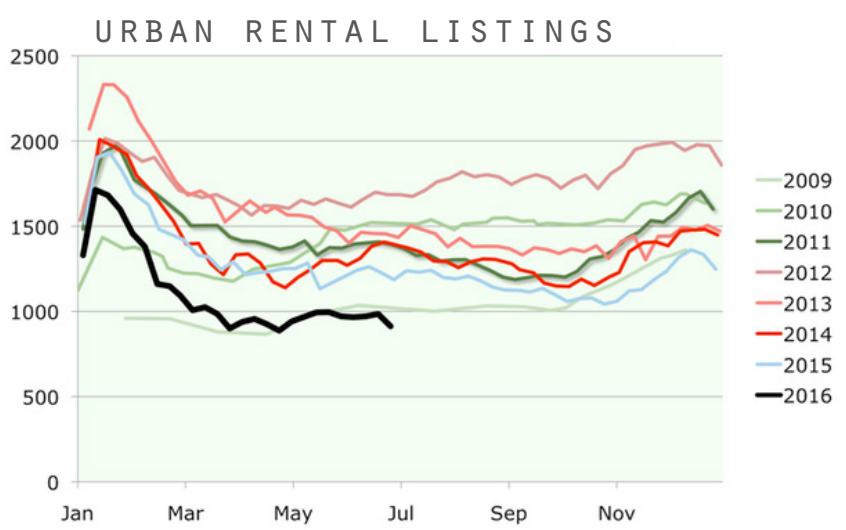

Above Fig 27. Urban Rental Listings (Wellington Rental Market Analysis, 2016). Rental Listings are well below 1000 compared with a more typical 1400 in the last 6 years.

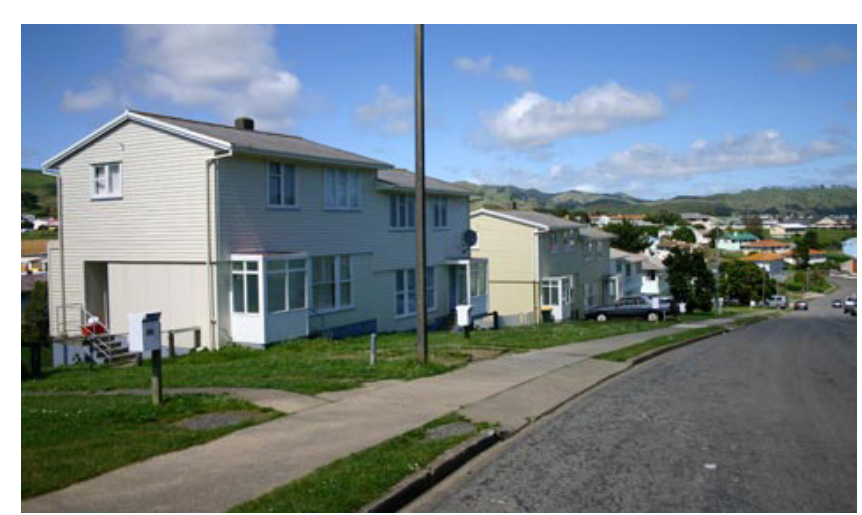

Above Fig 28. State Housing (Timutimu, 2014). Photographs showing the different buidling typologies that are common in the Porirua region.

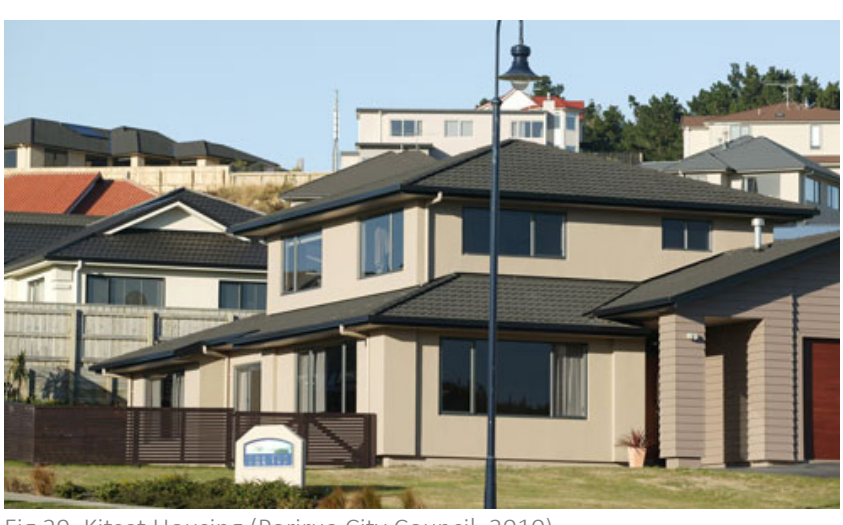

Fig 29. Kitset Housing (Porirua City Council, 2010) 


\section{RECREATION \& TRANSPORT}

Porirua region has a variety of natural features and open space allowing good opportunities for outdoor recreation activities reveal not only the natural ecology of the region but also the cultural heritage sites.

Neighbourhood parks and reserves are well distributed and are all reasonable walking distances to and from the town center, while large amenity sports and natural amenities are more spread out. Although there are plenty of recreationa activities on offer in Porirua there seems to be a lack of interconnectedness between spaces. Porirua Council's Transportation Strategy 2012 mentioned that there are no dedicated on road cycle paths within the city and walkways are under used. Currently there is a north-south cycle/ walking spine exists following the main state highway $1 /$ railway corridor, known as Ara Harakeke which provides connectivity to Pukerua Bay, Plimmerton, Mana/Paremata and Porirua CBD but does not look to extend into adjacent Porirua Suburbs to the west (PCC, Porirua Transportational Strategy, 2012)

Because of the declining rates in the use of cycling and walking as a mode of transportation the statistic has been reflected in the Porirua Transportation Strategy as having potential in addressing traffic congestion, road safety and levels of physical activity. Increased cycling and walking will bring direct benefits in terms of reduced environmental impacts and improved personal health providing a sense of identity and contributing to economic activity within the Porirua Region.

New Zealand Travel Survey stated that $75 \%$ of trips are made by motor vehicle, one third of these trips are under $2 \mathrm{kms}$ in length and two thirds are less than $6 \mathrm{kms}$, many of these trips could be made by public transport, walking and cycling (PCC, Porirua Transportational Strategy, 2012). There is a need for safer walking and cycle trails. North western suburbs such as Takapūwāhia and Titahi Bay have been earmarked as potential contributors with much of their open space being popular destinations/community hubs for people in Porirua (Ngāti Toa Marae, Titahi Beach etc.), these locations could provide initiatives that help strengthen recreation connections for other landscape enhancements to follow on for the region.

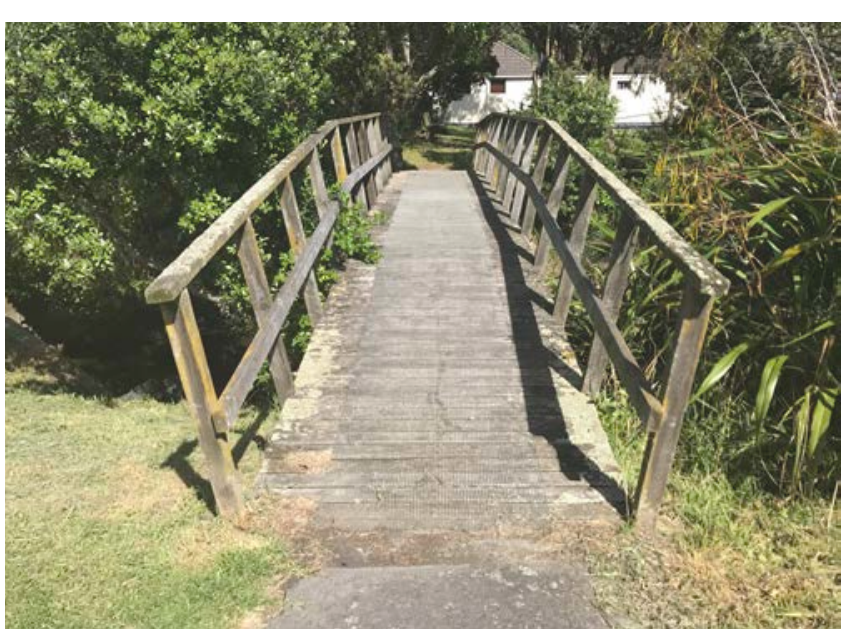

Fig 31. Village Footbridge (Authors own)

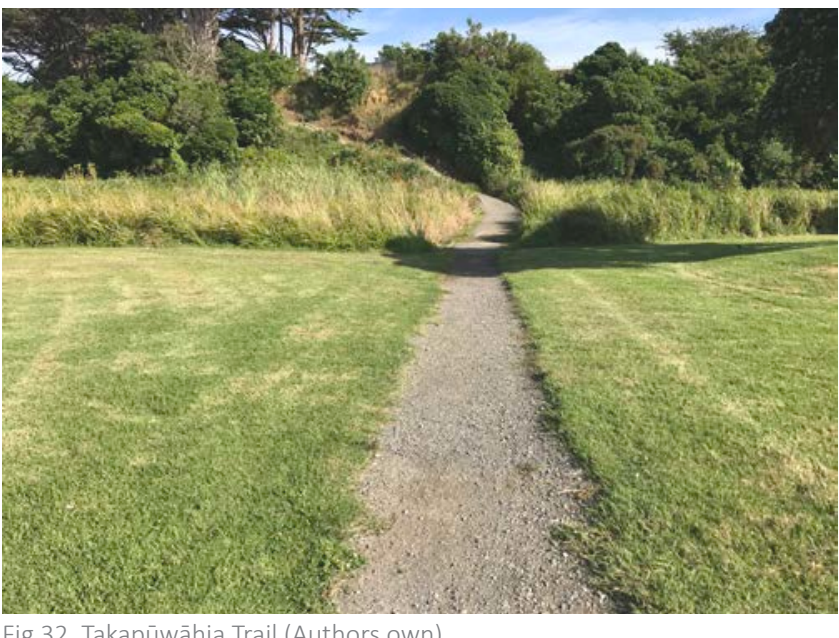

Fig 32. Takapūwāhia Trail (Authors own) 


\section{COUNCIL VISION}

The council's vision (2012) (PCC, Recreation + Open Space Strategy, 2012) for the Porirua region is to create a collection of distinct villages that are interconnected through enhanced green spaces that complement the encompassing harbour. They envisage these spaces to be safe and efficient connections into the city center. Porirua council plans to establish an ecological corridor and open space network that is integrated into the built environment with the hope of enhancing the continued efforts of nurture and restoration in its current reserves, wetlands, and riparian margins of the streams. Three themes that are specified as major focuses for the council are:

1. Protection of natural and historic heritage, coast line, waterways, and forest areas.

2. Connections between ecological, recreational, cultura and economic efforts.

3. Leisure opportunities for outdoor, indoor, casual, and organised activities.

\section{Goals:}

- Public open spaces are to be healthy, well maintained, connected and enjoyed by all.

- People are able to be safe and easily connected with access to great places and activities for recreation and sport.

\section{Outcomes:}

- Public develop pride in place and participate in the care and upkeep of parks and open spaces.

Native plants and animals are able to thrive and live in healthy habitat.

- Historic and cultural heritage is protected and well represented amongst the Porirua region.

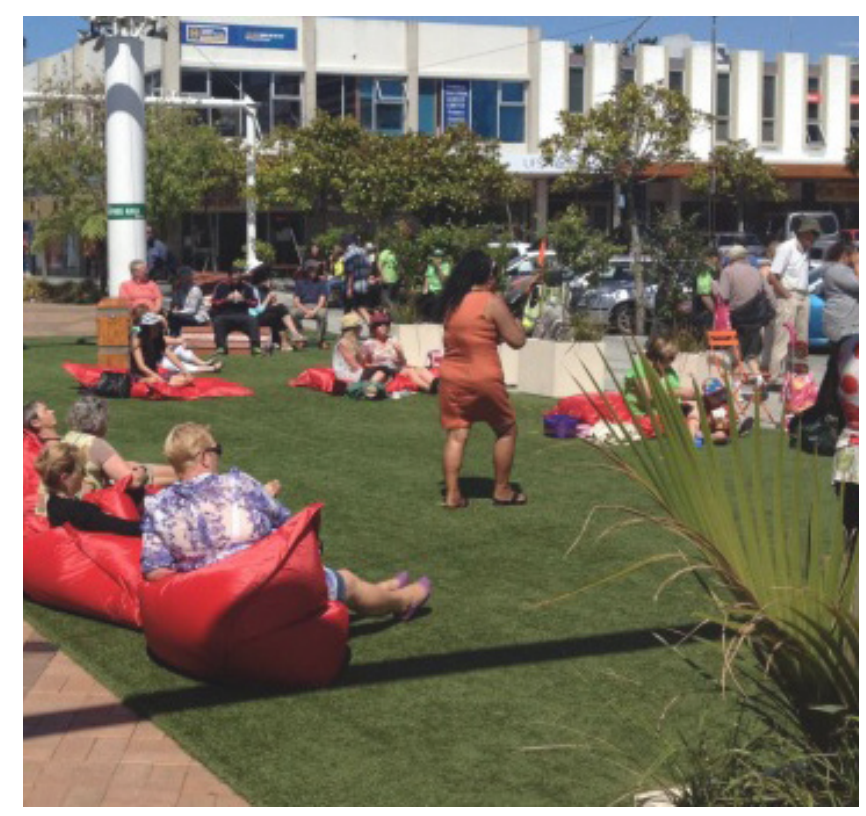

Above Fig 33. Porirua Markets (Whitfield, 2016). Photograph of the centra city carpark on a Saturday morning. The Markets offer a great variety of food and fresh vegetables. 


\section{PCC STRATEGY}

\section{Caring for our Parks and Open Spaces}

- Identify and implement initiatives that support sustainable procurement of resources. [PCC]

- Volunteers and Care Groups are encouraged and supported.

- Support Parks and recreation are managed sustainably.

- Village planning processes are used to help improve community ownership of local parks. [PCC]

\section{Native Plants and Animals live in Healthy Habitats}

- Pests and weeds are controlled.

- Degraded natural environments are restored, protected and enhanced (priority on those places with catchment relationship to inlet and harbour).

- Regularly monitor key streams flowing through reserves. [GW, PCC]

- Waterway and biodiversity network connection improvements to Regional Park. [PCC, GW]

Historic and Cultural Heritage is protected and easy to experience.

- Our cultural heritage is evident in the protection, design and use of open space.

- Our historic heritage is managed to protect or restore its values.

- Incorporate cultural and historic values in capital development project briefs and budget for design, signs information and interpretation. [PCC, Historic Places Trust, Te Runanga o Toa Rangatira]

\section{NGATI TOA STRATEGY}

Māra Kai \& Nursery (A Sustainable Community)

- Establish and maintain a Māra kai and nursery at 6 Ngātitoa St.

- Initiate sustainable examples at the site such as solar powered lighting, renewable energy options, and a water infiltration system

- Establish and maintain fruiting trees at appropriate areas in the community.

- Encourage a seedling base for community use. [Tupuna]

\section{Enhance our Natural Environment (Mitigate flooding/storm water)}

- Implement landscape and restoration plan for each stream (Maintain and monitor restoration)

- Mapping of existing and potential habitat; barriers to fish passage.

- Undertake a community survey to identify remaining areas at risk from flooding. Develop a remedial plan with council to alleviate risk of flood at identified sites.

\section{Marae and Iwi Education (Historic Narrative)}

- Extend paving design as depicted on Te Hiko Street to encompass the front of the marae complex on Ngāti Toa Street.

- Provision of visually appealing seating outside the complex to accommodate manuhiri that are waiting to be called onto the Marae.

- Encourage rongoa Māori (traditional herb) species at marae and in community. [Tupuna]

COMPARISON OF VALUE SYSTEMS

For more information refer to the Appendix 


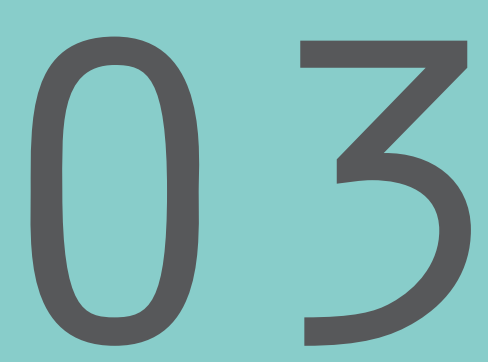

LITERATURE REVIEW

This section looks at some of the benefits of using digital tools and how they can be integrated into an indigenous collaboration. 


\section{VIRTUAL \\ INFORMATION \\ MODELLING}

There are a number of 3D spatial software packages on the market today, but nothing that specifically focus on the complexities of digital landscape modelling. Although elements of this research can be rendered using design industry software packages, the landscape visualisations and appropriation of digital techniques fail to portray 'realistic' landscape elements such as terrain, vegetation, and water. Some techniques for creating convincing static visual representations have been developed but tend to be complex and limited in terms of interacting. In reality landscapes are dynamic environments and current digital techniques used for the representation of these dynamics are still in their infancy.

"Landscape architects have powerful visual tools capable of changing people's perceptions and perhaps motivating action at various levels" (Sheppard, Shaw and Flanders) VIM seen today lack the ability to bring in choreographic sequences and vernacular identity that could give animations significant representational depth. They are limited in capturing traditional knowledge and demonstrating the relationships between indigenous communities who have an affinity or ontology to their landscape. The modelling tends to be structured around physical performance analysis techniques and not the relationship dynamic of people to place. The absence of these representation for indigenous communities is the gap that this research aims to be framed around.

This research has been designed to draw key learnings from indigenous communities and an understanding of the integral relationship they have to cultural landscapes. The process of visualising the landscape through their eyes using a developed visual information model, will allow designers to better represent indigenous knowledge. This collaborative approach has the potential to develop a unique ontological and representational model with both cultural values and performance integrated overlays

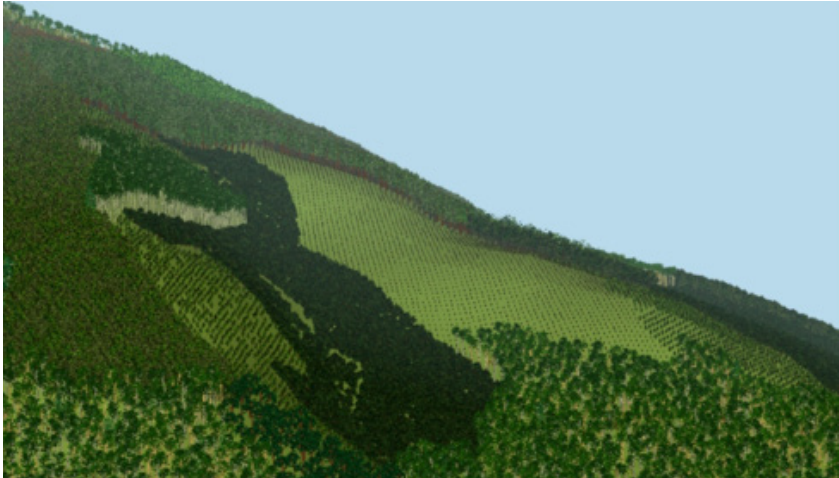

Above Fig 34. Ecology VIM (NICOGGRAPH, 2013). Screenshot from GreenLab Amap research team who have developed a system where they use modelling software to track the growth and architectural development of plants, from individual specimens to varied populations. 


\section{VALUE OF 3D DIGITAL LANDSCAPE VISUALS}

Vision is easily the dominant human sense when perceiving the environment. In the past the two dimensional representation of landscape visual information has been used through maps, plans, and sections however these can be misread spatially. Dynamic 3D digital visualisations give us the opportunity to understand environmental changes before they occur and model more closely to our visua sense through perspective. They also give the ability to share, experience and explore dynamic environments to enable informed discussion and better decision making

Human responses to environmental or visual stimuli such as landscapevisualisations, can be broadlycategorizedasfollows: engagement (level of interest and attention); cognition (related to knowledge, awareness and understanding); affect (related to feelings, perceptions, and emotions); and behaviour (related to changes in behaviour of the viewer) (Appleyard, 1977, pp. 43-88) (Zube, Sell, \& Taylor, 1982, pp. 1-33). In the collective sphere of community planning related consequences such as capacity-building (to deal with climate change), policy change, and decision-making are also important (Sheppard, Local Climate Change Visioning: A New Process for Community Planning and Outreach Using Visualization Tools, 2008). The possibilities for landscape visualisations are endless with climate simulation, design simulation, historic narratives and real-time data all pushing the boundaries of how we currently operate.

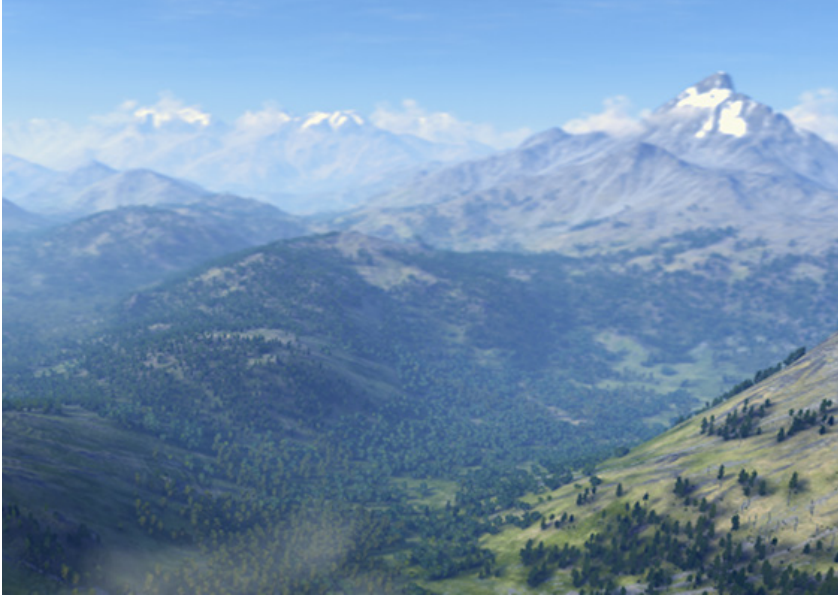

Above Fig 35. Game Visualisation (Rigney, 2013). Screenshot of a 3D landscape visualisation from a research paper comparing 2D versus 3D Landscape visualisations with regard to economic valuation - landscape scenario is based in the Alps. 


\section{INDIGENOUS LANDSCAPES}

The term 'Indigenous Landscapes' is described by scholars today in terms of cultural constructs and the interactions between people and nature over time.

Since humans existence different ethnic groups have developed descending from and identifying themselves as indigenous of a given region, in contrast to groups that have settled, occupied or colonized the area more recently. Avid 'vernacular landscape' writer John B. Jackson defines landscapes as "...never simply a natural space, a feature of the natural environment. Every landscape is the place where we establish our own human organization of space and time" (Jackson, 1984, p. 156). Indigenous groups can maintain their traditions or other aspects of a culture through particular features of their landscape. This can mean relating to the land as a living entity with spiritual like qualities.
With the accelerated losses of biodiversity, habitats, and native languages, indigenous knowledge, including the study of traditional ecological knowledge of species and landscapes maintained by native nations, has become ever more significant. Many indigenous place-based knowledge systems pre-date the formal articulation of Western and Eastern scientific tenets by thousands of years. In particular there is a need to support and incorporate indigenous cultures into projects that restore habitats of declining species and resuscitate lost practices and landscape knowledge. Although there are already growing efforts, ranging from large-scale indigenous led monitoring programs of wildlife populations (Luzar, et al., 2011, pp. 771-781) two examples of mapping traditional lands, in the little known Darien province of Panama (Herlihy, 2003, pp. 315-331), traditional knowledge is rapidly shifting if not dramatically eroding between generations as formal education and social media have eclipsed oral transmission from elders.
Understanding the importance of Indigenous landscapes is an integral part of the process of examining and celebrating cultural diversity. They are important as they contribute significantly to our well-being and quality of life by providing the broader context within which we live our lives. Without having first served an appropriate apprenticeship in learning about the culture, its history, cosmogony, customs and language. Too often, the lack of these attributes has led to subsequent misuse and even abuse of superficially acquired knowledge, thus reinforcing the reluctance of many indigenous groups to share their knowledge with uninitiated. 


\section{CONTEXTUALISING INDIGENOUS NZ LANDSCAPES}

The indigenous people of New Zealand (Māori) are not an entity on the landscape, but see themselves interconnected in a holistic sense. They see their role not as an obligation to resolve environmental issues upon their own landscape, but as working symbiotically, coexisting, sharing, and protecting one another. Maori share with other indigenous people a legitimate concern and apprehension when uninitiated enter their cultural world. "To Māori the land is part of the living body of the tribe. It is not just that they are sentimentally attached to it because they have lived there all their life and because their ancestors are buried there. Inseparable from the land are the multiplicity of spirit beings which make up the authority (Mana) of the tribe" (Schwimmer, 1966)

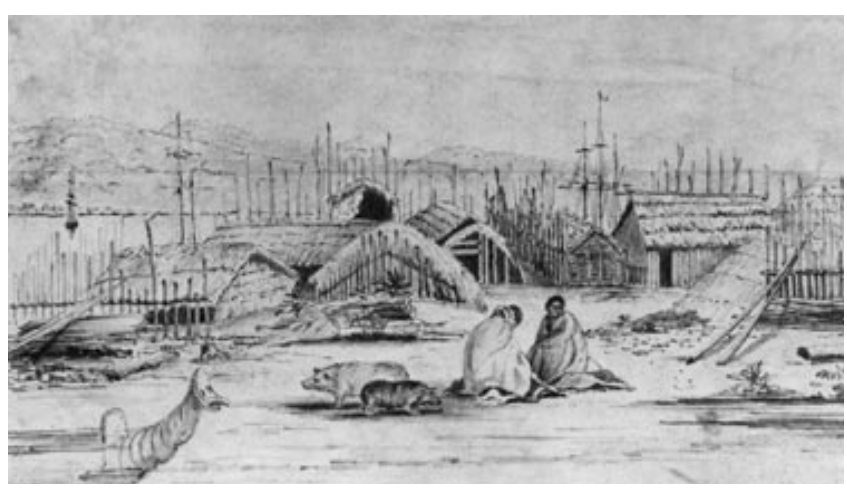

Above Fig 36. Te Aro Pā in the 1840's (Norman). One of the most central city pā sites to be discovered in Wellington.

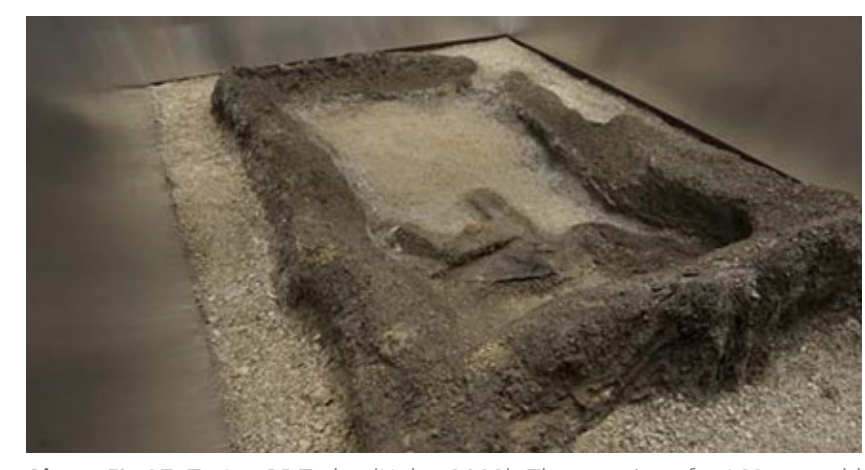

Above Fig 37. Te Aro Pā Today (Heke, 2008). The remains of a 160 year old pā site that can be viewed on the ground floor of a multi-million dollar high rise development in the heart of Wellington City. 


\section{MAORI COSMOGONY}

Maori cosmogony underpins the traditional relationship between Māori and the land: ngā tikanga whenua. Māor customs, values and attitudes, inadequately described as "the Māori worldview" or belief system, (Marsden, 1975) derive ultimately from an indigenous body of knowledge which seeks to explain their understanding of existence.

Most versions consist of recitations of creation events arranged in genealogical order. The story begins with Te Kore; the realm of chaos where Io, the Supreme Being conceived the subsequent voids from which Ranginui, the sky father and Papatuānuku the earth mother would emerge. (Buck, 1950). From these primal parents arose many offspring, atua (supernatural beings), each responsible for, or guardians of particular natural phenomena. Tane nui a Rangi (Tane the greatest son of Rangi) also personified as Tane-mahuta (god of the standing forest) eventually separates his parents and transitions the world from darkness, Te Po, to the world of light, Te Ao Marama, and a new phase that eventuates in the whakapapa (genealogical continuum) of people.

MAORI GODS, GODDESSES AND ANCESTORS

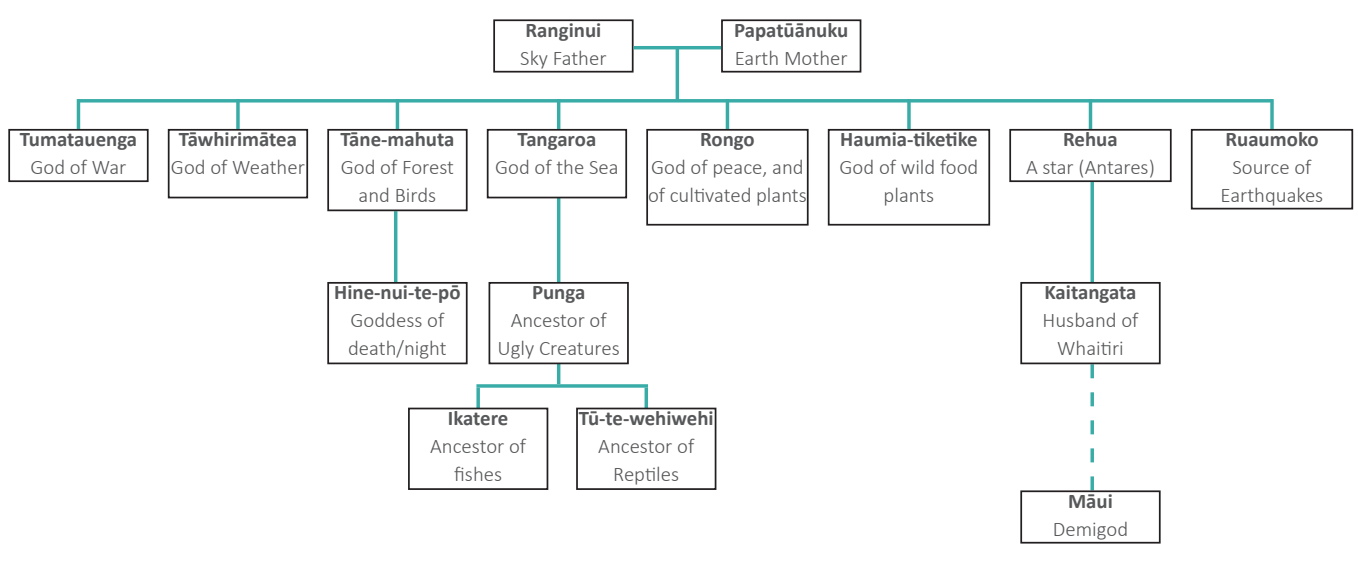

Above Fig 38. Māori Origins (Authors own). Diagram illustrates the environment as family - the offspring of Ranginui (Father) and Papatūānuku (Mother). It portrays how Māori view the origin of the universe and all things living. Refer to appendix for more information. 


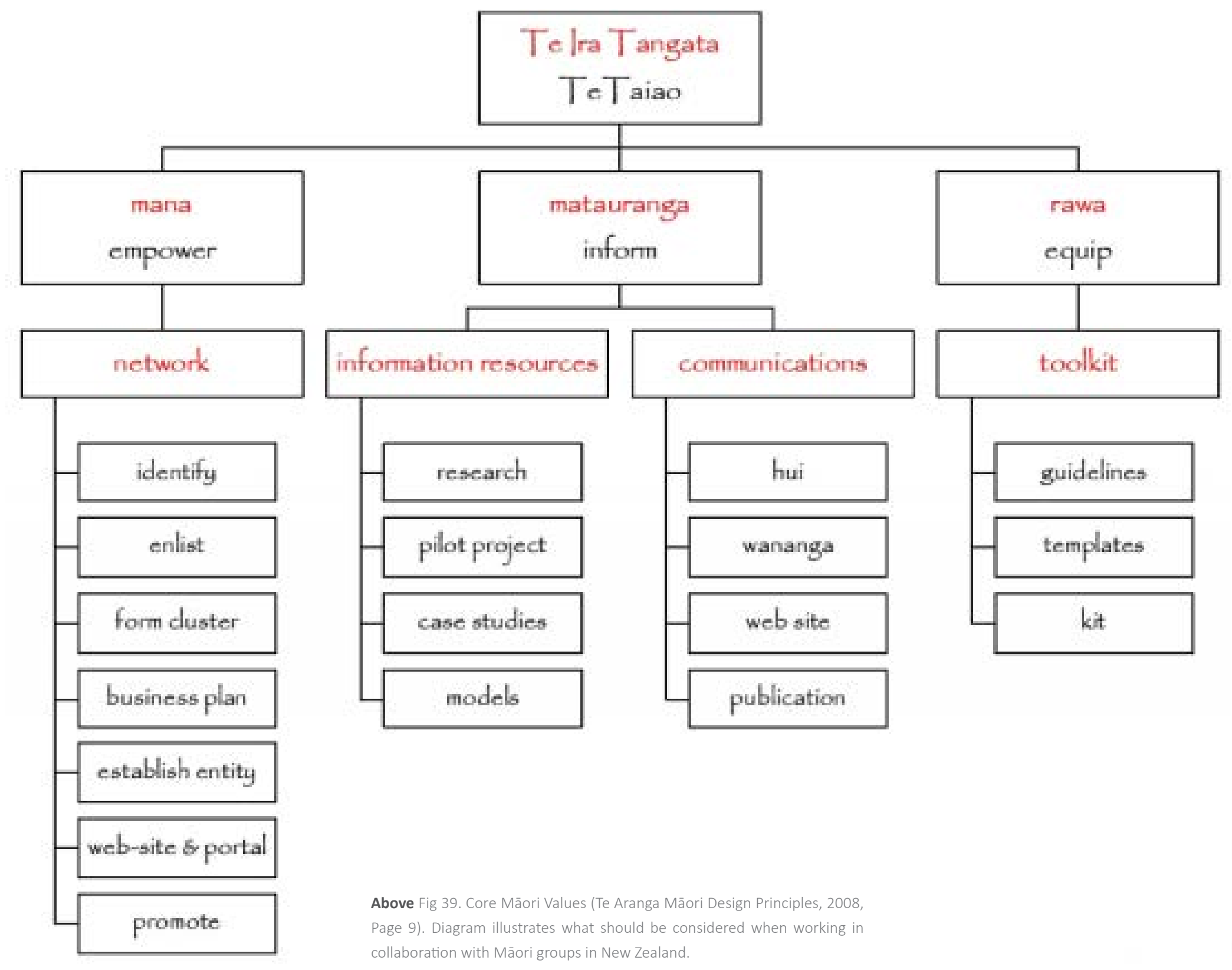




\section{CORE MAORI VALUES}

Māori have holistic and interconnected relationships with the natural world and its resources, with a rich knowledge base - mātauranga Māori- developed over thousands of years and dating back to life in Polynesia and trans-Pacific migrations. Core Māori values have been informed and considered as pertaining to Māori in general but within that iwi and hapu have their own distinctive, although recognisably similar, perspective (DOC, 1994). These process-oriented principles have provided the foundation for, and underpin the application of, the outcome-oriented Te Aranga Māor Design Principles (Steering Committee, 2008).
Rangatiratanga: The right to exercise authority and selfdetermination within one's own iwi/hapū realm.

Kaitiakitanga: managing and conserving the environment as part of a reciprocal relationship, based on the Māori world view that we as humans are part of the natural world.

Manaakitanga: the ethic of holistic hospitality whereby mana whenua have inherited obligations to be the best hosts they can be.

Wairuatanga: the immutable spiritual connection between people and their environments.
Kotahitanga: unity, cohesion and collaboration.

Whanaungatanga: a relationship through shared experiences and working together which provides people with a sense of belonging.

Mātauranga: Māori/mana whenua knowledge and understanding 


\section{今is}

METHODOLOGY

This section looks at the research response and development of a new type of landscape system based upon utilising digital tools to serve cultural attitudes towards land resources and management.
INTERACT IVE DIG I TAL LANDSCAPE SYSTEM

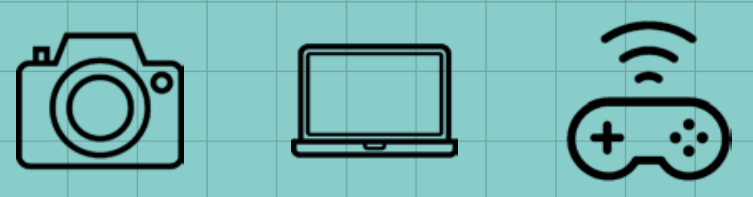

DES I GN S IMULAT I ON

of 


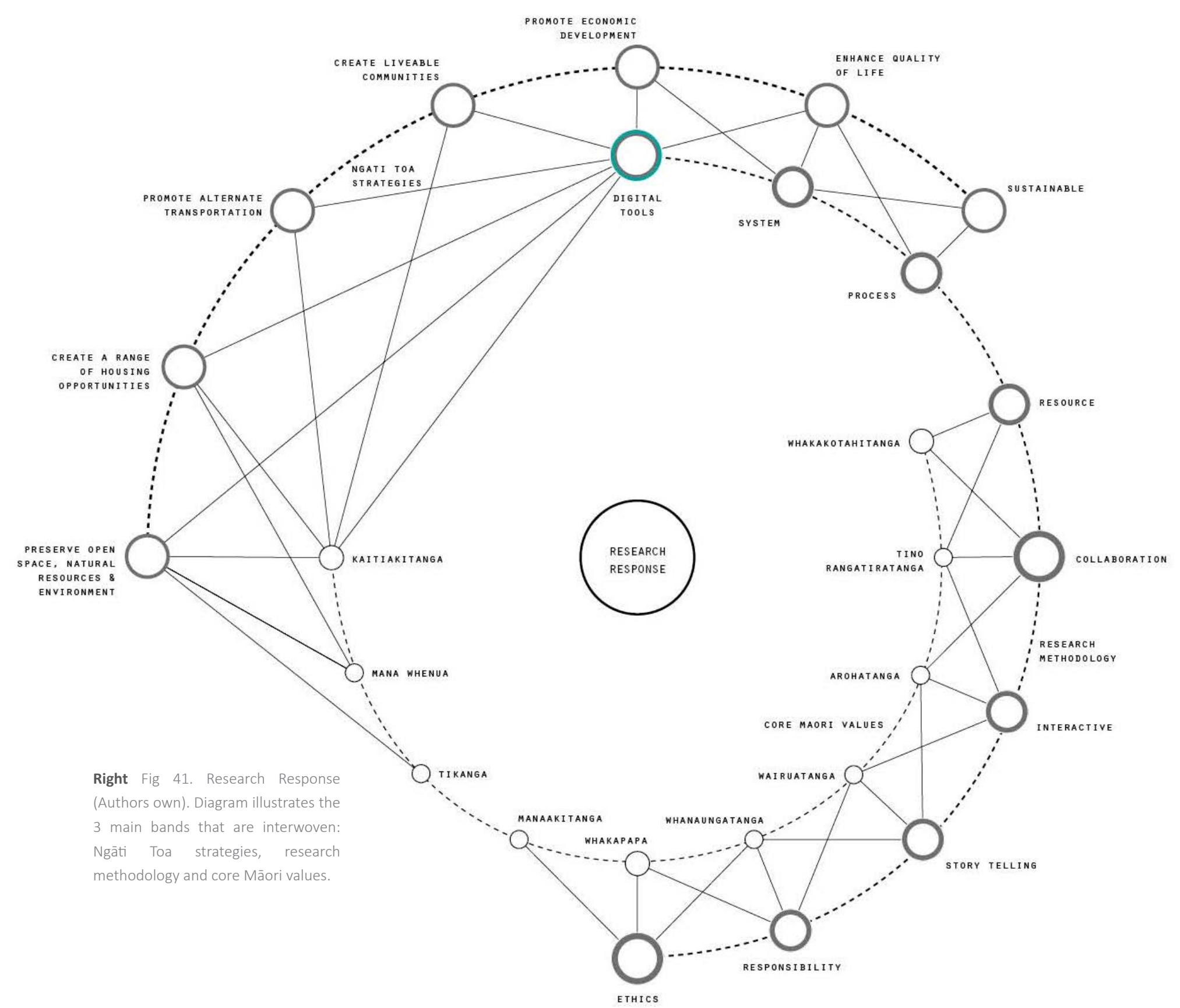




\section{RESEARCH INTENTION}

A core part of this research included acknowledging the interests through collaboration and incorporation of Māor values. Research through design has been used to propose a system to this problem with a resolution which mirrors a holistic approach and unites all involved from a new angle. Land management is a largely sensitive issue for indigenous groups so this research could continue in many directions. This research will investigate key digital tools and systems to gauge a potential value, while recognising challenges and barriers to overcome.

Due to the scope of the research, the study method will be carried out in three distinct stages; fieldwork; interactive digital landscape system; and design simulation.

The intention is to translate cultural values into an interactive indigenous digital landscape of a real world environment that can be used to simulate climate data, designs and landscape narratives for a specific indigenous group.

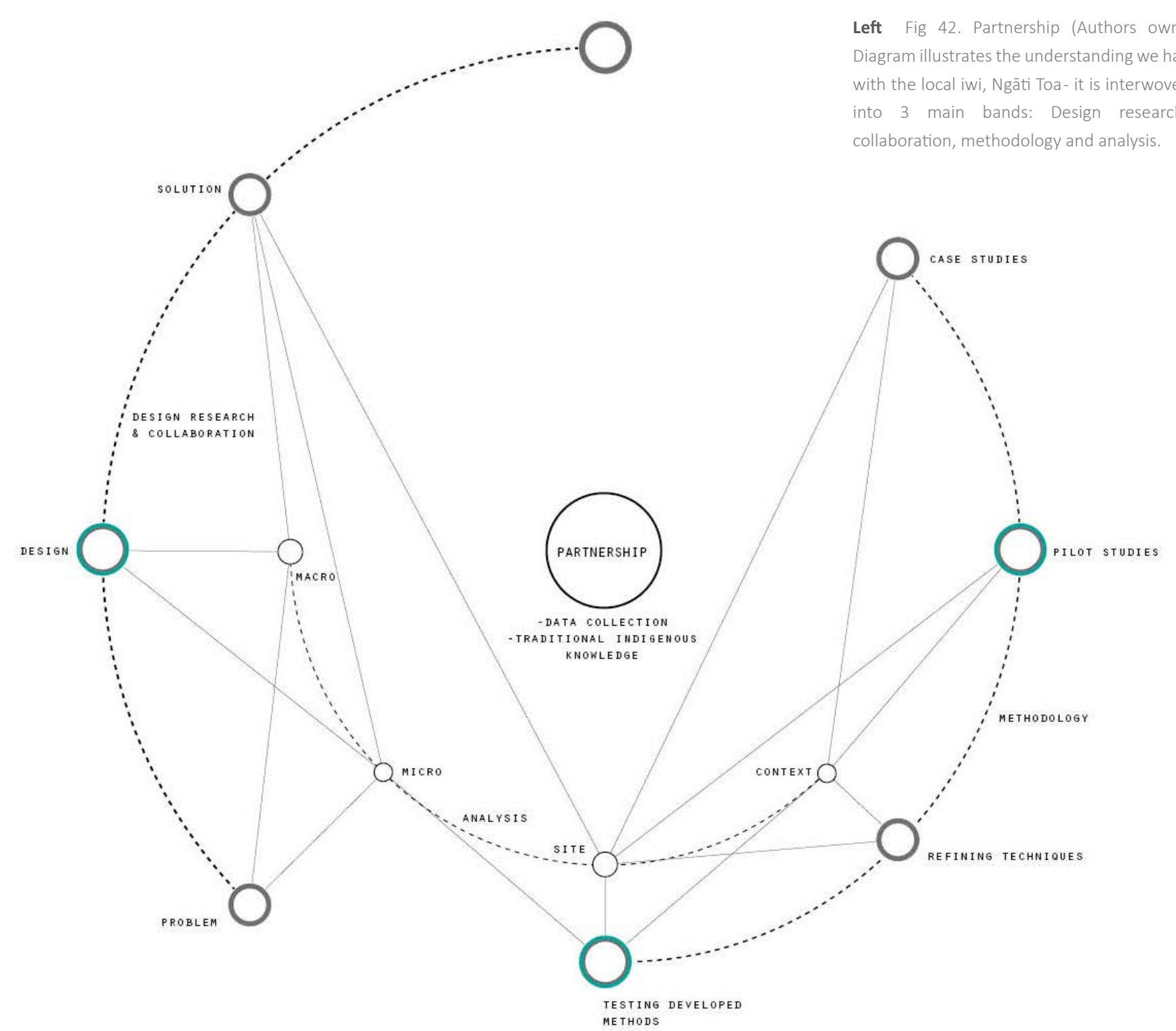




\section{METHOD}

This research developed a method that could be targeted to three specific audiences in order to acquire adequate information through the lens of the indigenous people; elders who are the bearers of historical information; returning and existing iwi members interested in the development of their environment; and young adults responsible for the future and prosperity of their environment. The method will test how collaboration can incorporate the underlying cultura values of a specific indigenous group and their landscape. Initial discussion will provide starting points which will dictate locations of site specific data collection.

Translating these values into the landscape will format our approach towards collecting data. Utilising tracking hardware will enable correspondence of data entry points entailing organised site specific data. The next step is to develop an interactive digital landscape visualisation system built upon the indigenous values with correlation to their land holdings. This step requires the replication of real world environments through photogrammetry processes involving a variety of hardware (drone technology; digital imaging camera, access etc.) along with optimal software designed to derive collected data and format for optimal resolution and representation among both 2 dimensional and 3 dimensional platforms (Autodesk Remake; Unreal Engine; Rhino etc.)

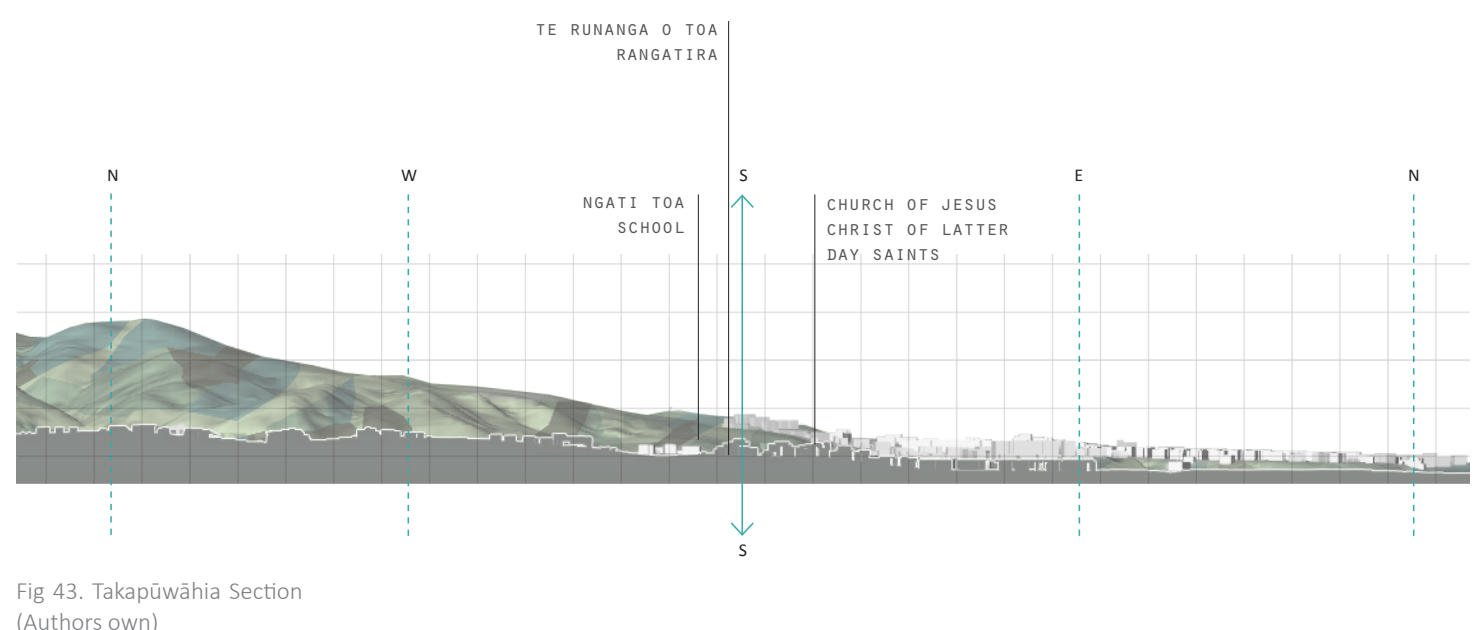




\section{FIELDWORK}

The fieldwork section allowed the research to gain immediate sensory responses to site whilst also gaining valuable scientific data. This understanding of site as an interwoven base served as a great starting point for accurately recreating and testing the site at a later stage as an interactive virtual environment. "Fieldwork gives the researcher an "on-theground", more realistic perspective than any second-hand, pre-digested/analysed account" (Pacheco-Vega, 2014).

Fieldwork analysis was essential to this research and was conceptualised as having three main dimensions: physical, perceptual (aesthetic) and associative. The physical dimension includes gaining an understanding of the earth sciences, ecology and hydrology, and the overlays of road and settlement networks, street and cadastral layouts, land uses and existing architecture. The perceptual dimension comprises direct appreciation through the senses, such as sound and smell. It also includes such aesthetic characteristics as clarity, coherence, and legibility (in a mental map sense). The associative dimension includes those aspects of a landscape usually reached by way of humanities, such as cultural meanings, history and spiritual aspects as transcendence, identity, belonging and continuity.

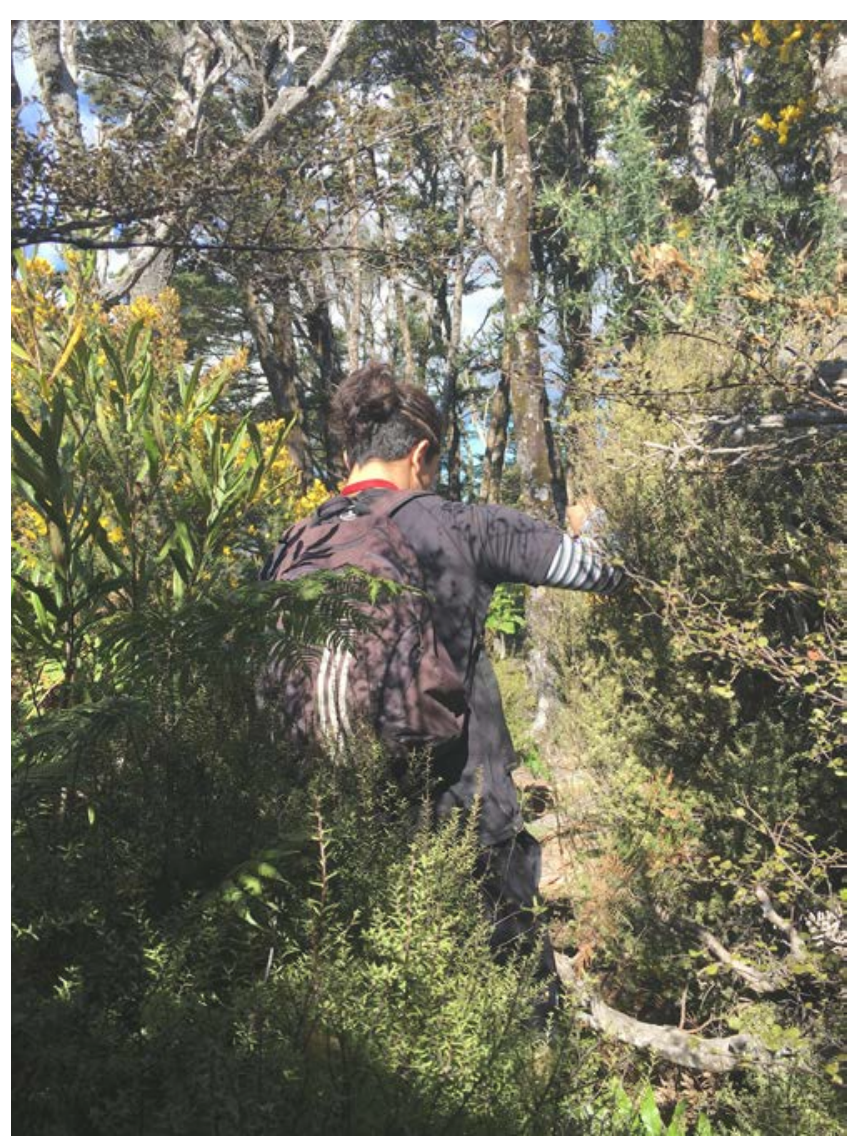

Above Fig 44. Takapūwāhia Fieldwork (Authors own). Photograph showing some of the Revegetation. Native planting has been slowly been regenerating amongst gorse bushes after being degraded for decades as farm land.

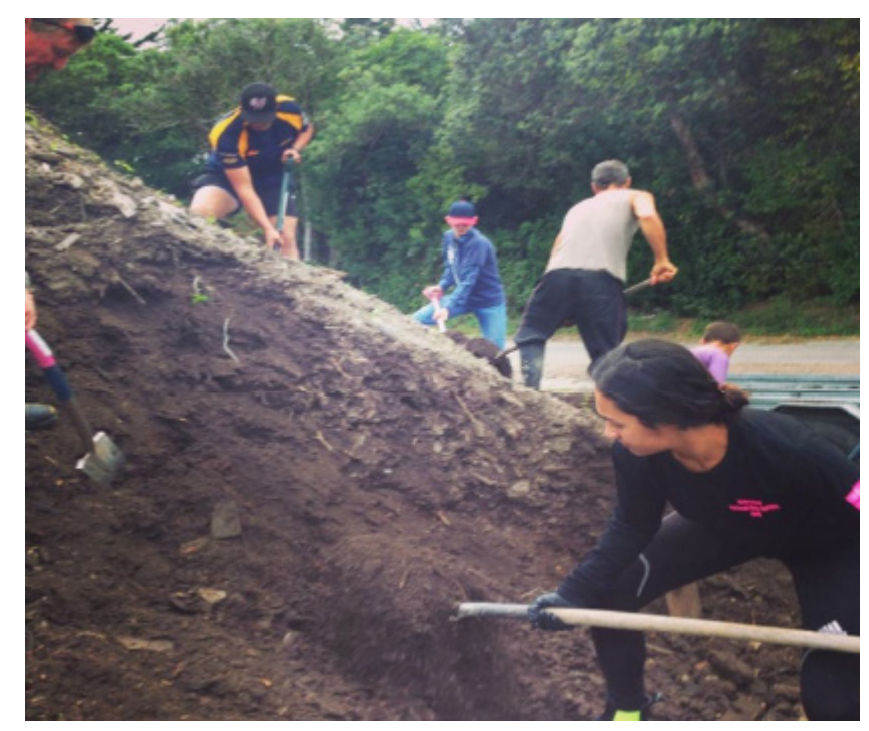

Fig 45. Māra Kai (Takapūwāhia Community Strategy, 2014 Page 21) 


\section{HARDWARE}

The GIS Mobile Data Collection (MDC) application was used as part of the physical dimension of the fieldwork analysis and links back to some of the core Māori values such as kaitiakitanga, whanaungatanga and mātauranga. This approach formed the backbone to the research approach and aided in the collaborative process to get the iwi on board. MDC was used as it is a free and open-source set of tools which helps organizations author, field, and manage mobile data collection solutions.

GIS MDC provides an out-of-the-box solution for users to:

\section{- Build a data collection form or survey.}

- Collect the data on a mobile device and send it to a server.

\section{- Aggregate the collected data on a server and extract it in} useful formats.
In addition to GPS locations and images, MDC helped enable iwi to engage in the research. By crowdsourcing, iwi members were able to individually download this application with our forms loaded and help aid in the building of a multimedia-rich nature mapping system. By contributing to the collection of data, members were able to gain form a new understanding of their environment and were able to see the benefits of utilising this type of system for iwi benefits.

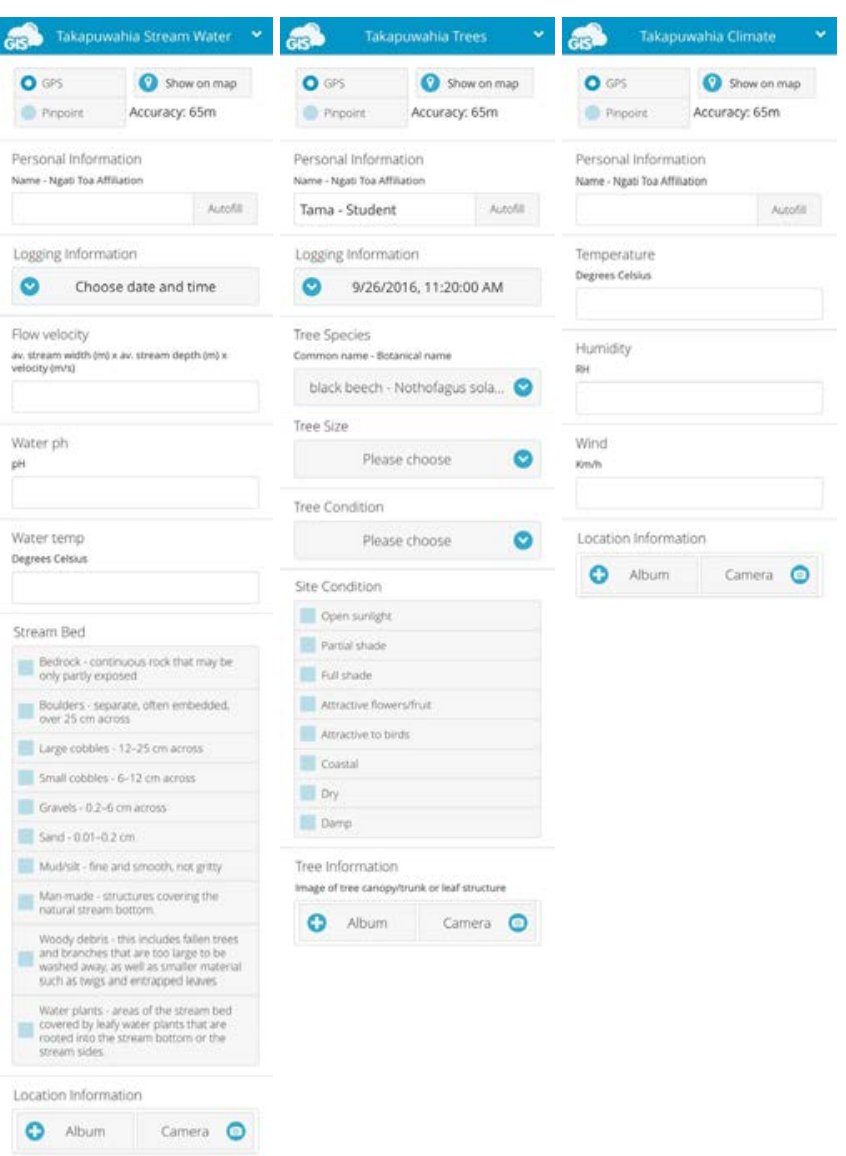

Above Fig 46. MDC Collection Forms (Authors own). Screenshots of three of the data collection forms that were designed specifically for the local iwi- The forms served as a way of crowdsourcing and getting members to survey their own landholdings in Takapuwāhia. Refer to appendix to see server map. 


\section{PHOTOGRAMMETRY}

Due to unforeseen circumstances the research was unable to utilise this technology and had to make do with capturing photogrammetry by foot. The scope of the intended research had to change to a smaller scale to which the system could still be proven. Site specific photogrammetry was switched to objects that could be identifiable by the iwi as belonging to a certain area. This capturing of smaller scale objects was still able to provide a collection of high quality images that could then be then used to create a collection of interactive 3D environments. This setback forced us to rely on extra compensation from other platforms such as Unreal Engine 4 to make up the majority of the landscape environments making it less true to form and accuracy. By including aspects of the landscape such as site specific objects the research was still able to portray intentions of cultural meaning, history and spiritual aspects connecting to iwi identity, belonging and continuity.

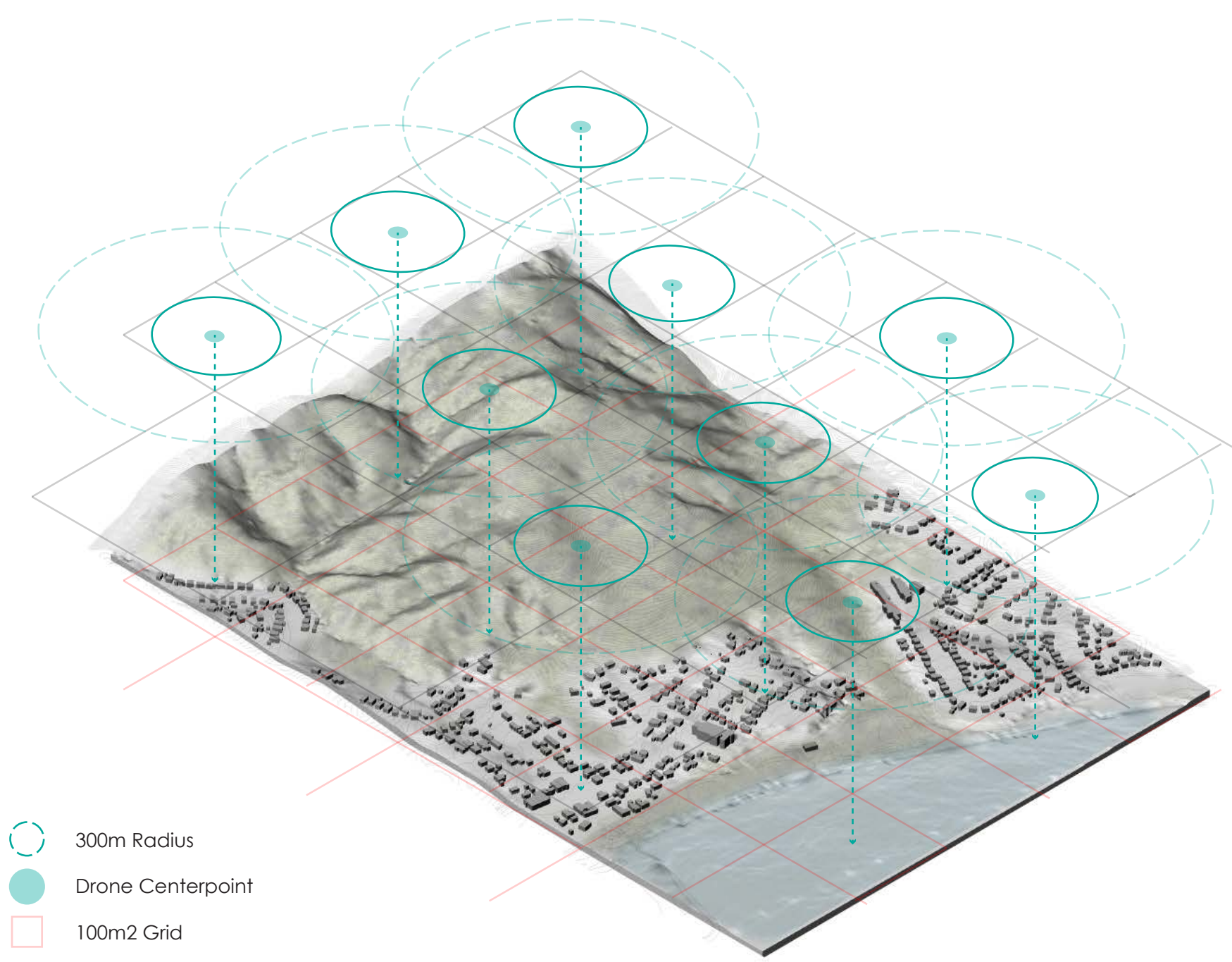

Above Fig 47. Photogrammetry Flight Zones (Authors own). Model illustrates some of the elected areas for the drone to capture the photogrammetry from. 


\section{PILOT STUDIES}

In order to test the research methods before implementation on our selected site we underwent small scale pilot studies as exercises to test different ways of executing the capturing of photogrammetry from ground level. Through these studies we were able to refine the process to get the highest quality 3D mesh possible within a succinct timeframe. These pilot studies helped to define a simple process with the main intention of being able to pass on these techniques to other people in an accessible form. To investigate the best practice photogrammetry approach, two pilot study objects were photographed.
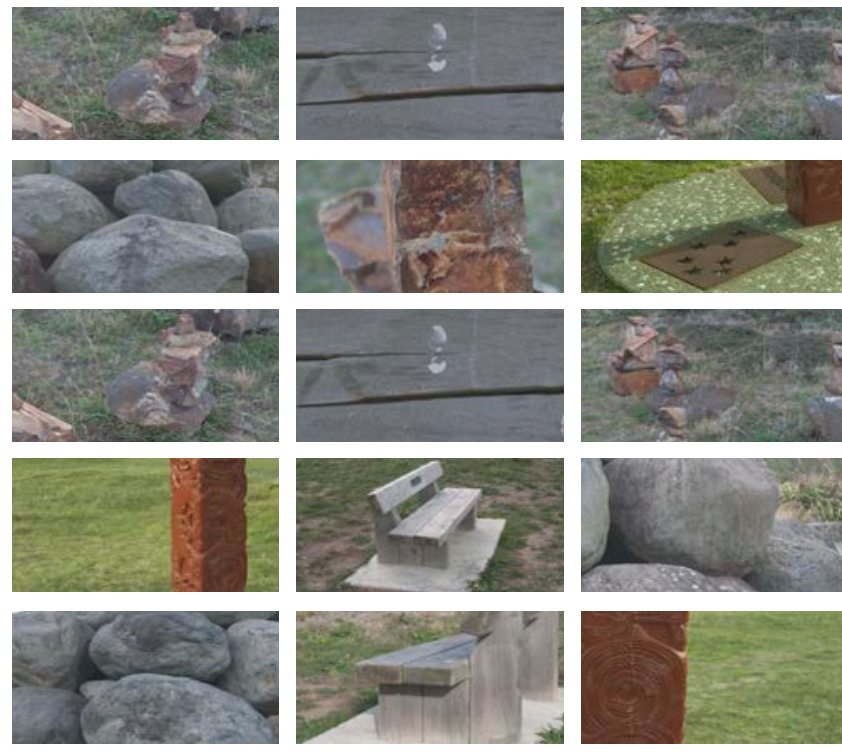

$=2$

30
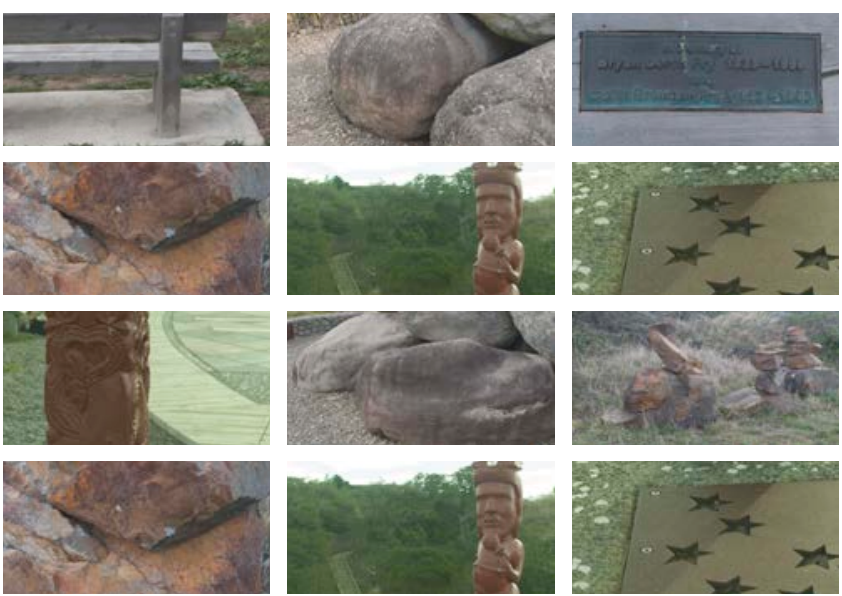

Above Fig 48. Pilot Study Photo Slides (Authors own). A small snippet of

some of the photos used for producing various photogrammetry models.
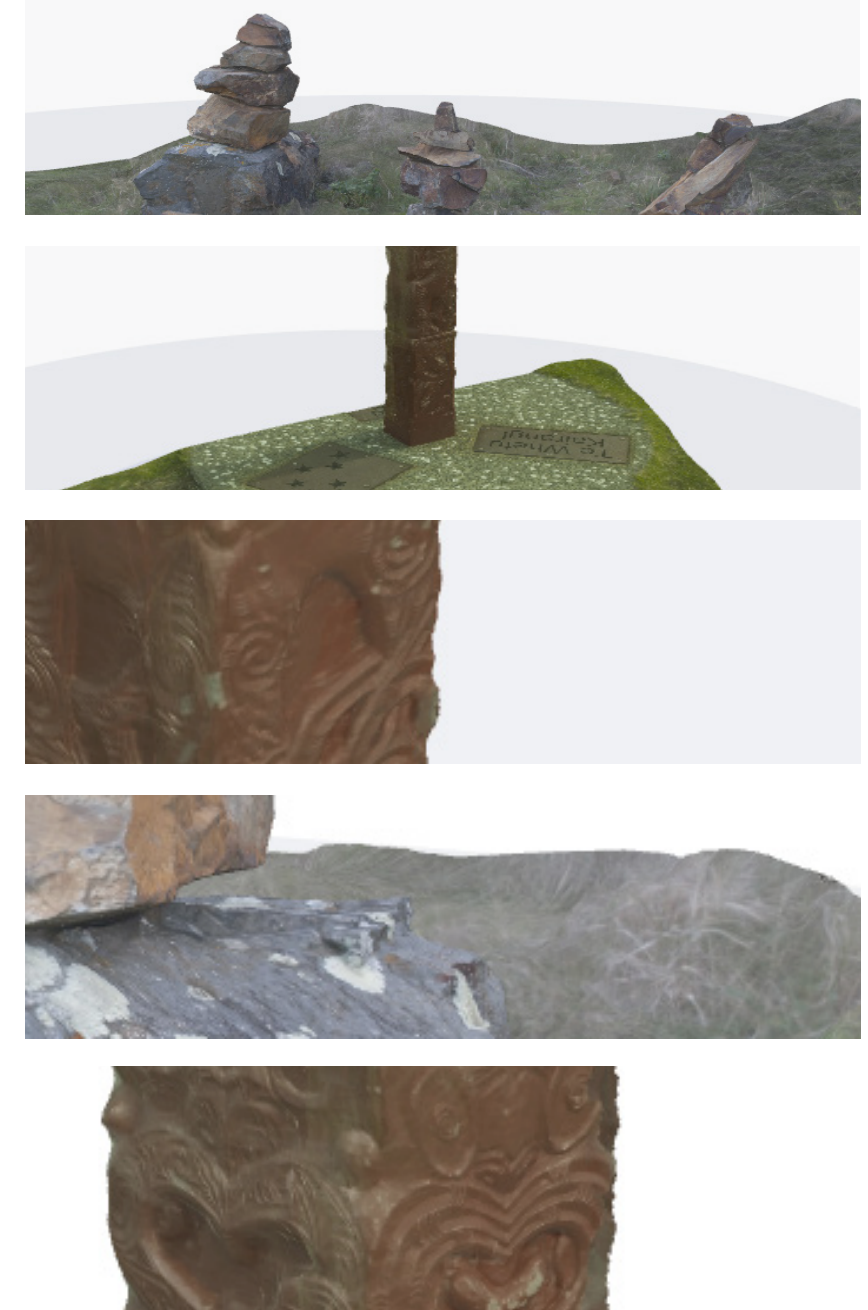

Above Fig 49. Photogrammetry Screenshots (Authors own) 


\section{ORUAITI PA}

The first object was captured using a handheld camera, set to standard JPEG format during a mid-morning schedule to reduce as much direct sunlight as possible. As shown, lighting remained an issue with too many disrupting shadows and spot lighting effecting the model. The other issue was the difficulty of capturing images of the subject from above (inaccessibility to higher grounding etc.). For this model, only $100+$ photos were captured which made for poor stitching in certain areas (top of the model and ground base). Although the collection process was fast (only taking around 5 mins for $6 \mathrm{~m} 2$ ) the end product was not to the standard we had expected.

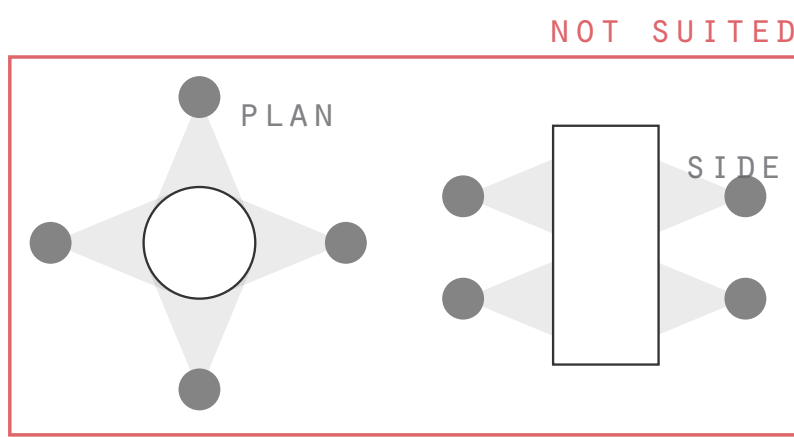

Fig 50. Poor Photo Angles Diagram (Authors own)

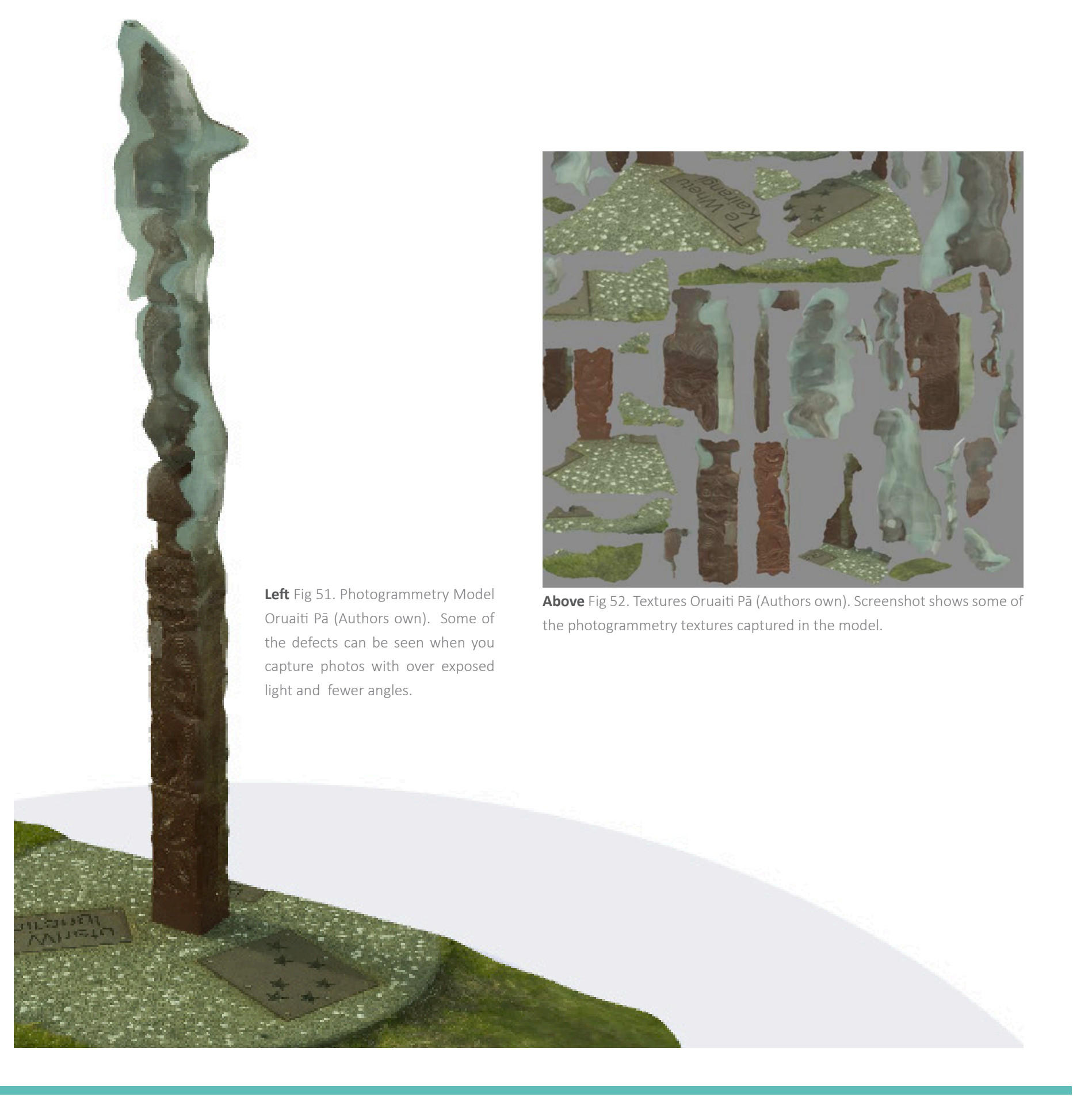




\section{PALMER BAY}

The second image shows a more refined model with a higher quality 3D detail. To test against the previous approach we used NEF Raw formatted photos on a rock formation in Palmer Bay. 200+ photos were photographed in the late afternoon when the lighting was monochromatic, this meant casting of low shadows and little reflection. The collection process is a lot slower taking around $20-25$ min for a site around $14 \mathrm{~m} 2$ but produced a collection of much more convincing 3D mesh. This approach proved to be the successor and was applied throughout the research.

PREFERRED OPT ION

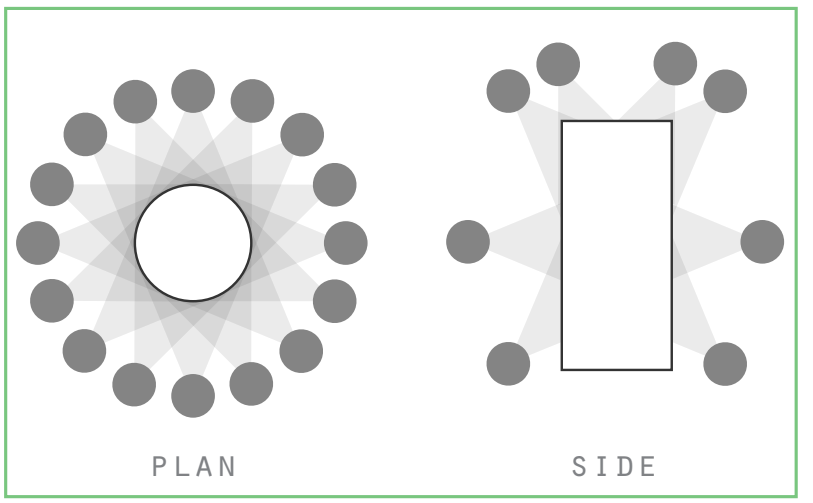

Fig 53. Correct Photo Angles Diagram (Authors own)

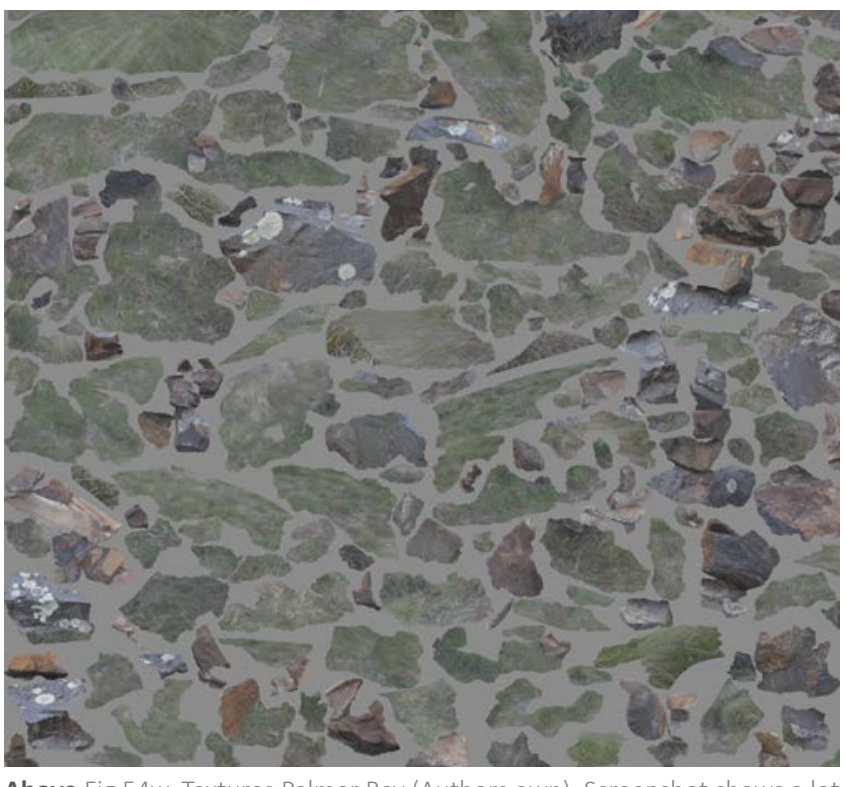

Above Fig 54w. Textures Palmer Bay (Authors own). Screenshot shows a lo more of the photogrammetry textures captured in the model compared to previous.

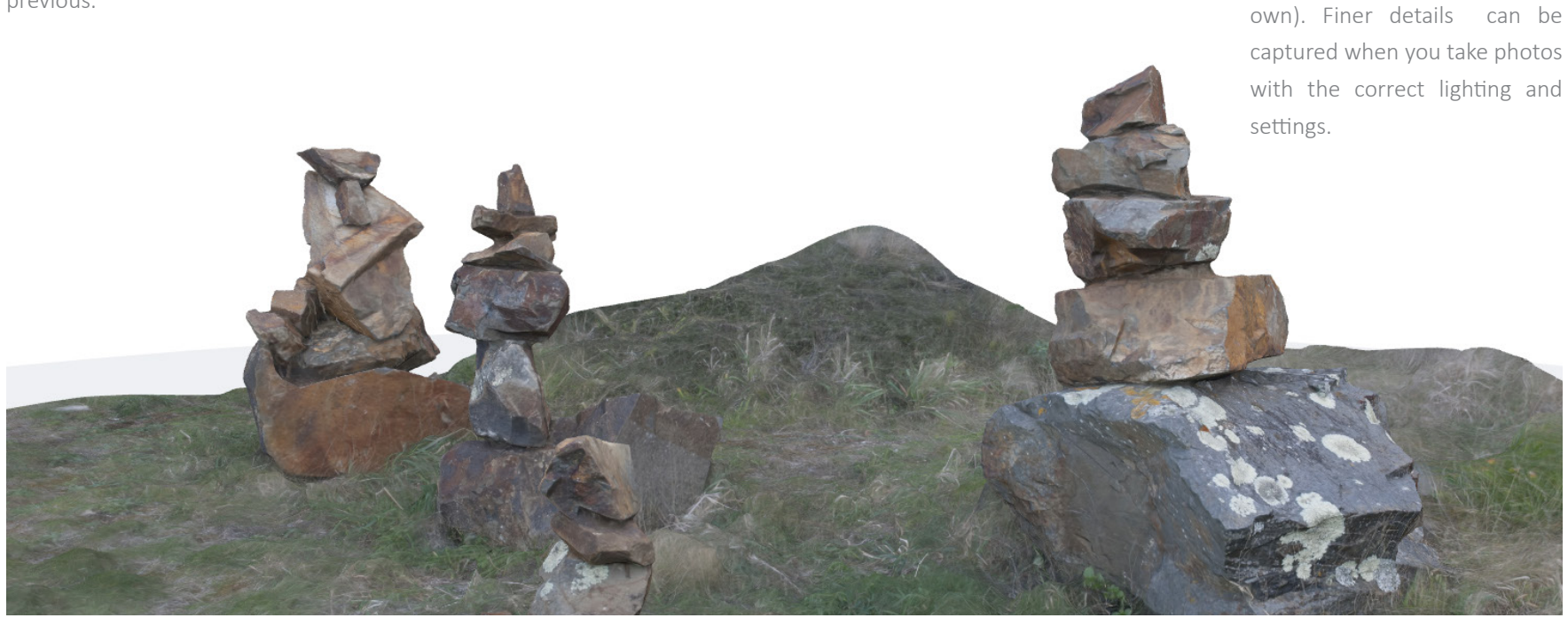

Below Fig 55. Photogrammetry Model Palmer Bay (Authors Model Palmer Bay (Authors 


\section{INTERACTIVE DIGITAL LANDSCAPE SYSTEM}

The digital resources currently available to the landscape profession are limited compared to other disciplines such as architecture. By refining and developing an interactive digita landscape system this research was able to create a reference or guide for other landscape designers to easily apply and tap into the digital realm with little or no experience. "Immersive, interactive systems that can effectively engage us within narrative experiences but still allow us to exhibit agency over our experiences have the potential to revolutionize the ways in which computational systems are used to entertain educate, and train humans" (O.Riedl \& Bulitko).
The potential to generate and test current and future land developments within the landscape system were tested in this section developing a model that integrates climate data, textured land base and cultural values in the emulation of a Māori cultural landscape. Through the design of a system we were able to communicate the research work with Ngāti Toa and its stakeholders to disseminate domain-based information of their land. By inputting location specific data the research was able to demonstrate landscape ecosystem scenarios and resource management, giving iwi an understanding of implications, impacts and risks with a view to local response and mitigation.

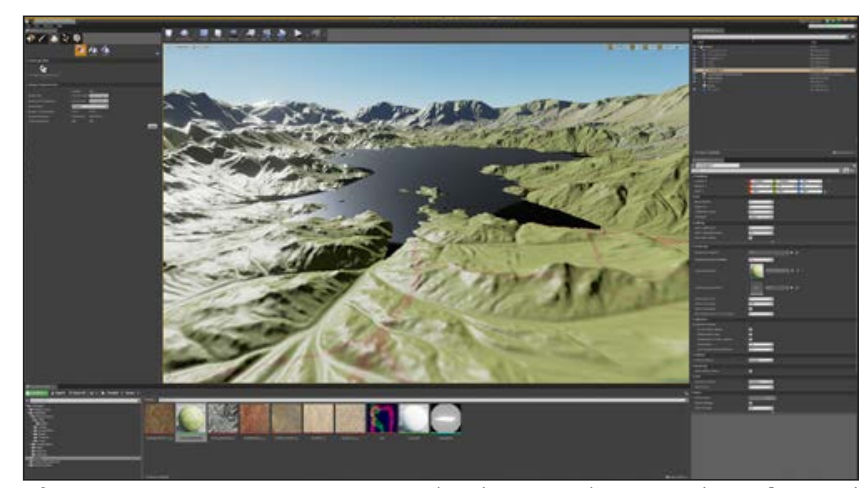

Above Fig 56. Porirua Region Ue4 (Authors own). Screenshot of Unrea Engine 4 processing the porirua region from a height map- Hill heights have been exaggerated. 


\section{REMAKE SOFTWARE}

The software selected for processing captured photogrammetry was Autodesk Memento (ReMake). It is an end-to-end solution for converting reality captured photos and scans into high-definition 3D meshes. The meshes can be cleaned up, fixed, edited, scaled, measured, retopologized, decimated, aligned, compared and optimized for downstream workflows.

To achieve an accurate photogrammetry model, the trimming of any excess areas were removed. Detect \& fix mesh issues were identified and points closed on the model, reducing the risk of faults later on when exporting to game engine. ReMake allowed for a simple process re-scaling objects and allowed for manipulation if needed to extrude the photogrammetry to correct heights and/or lengths. Finally reducing the face count and adding coordinate points would make the model geographically accurate, so when exporting as FBX to use in Unreal Engine 4 the model could be placed correctly on the $x$ and $y$ axis.
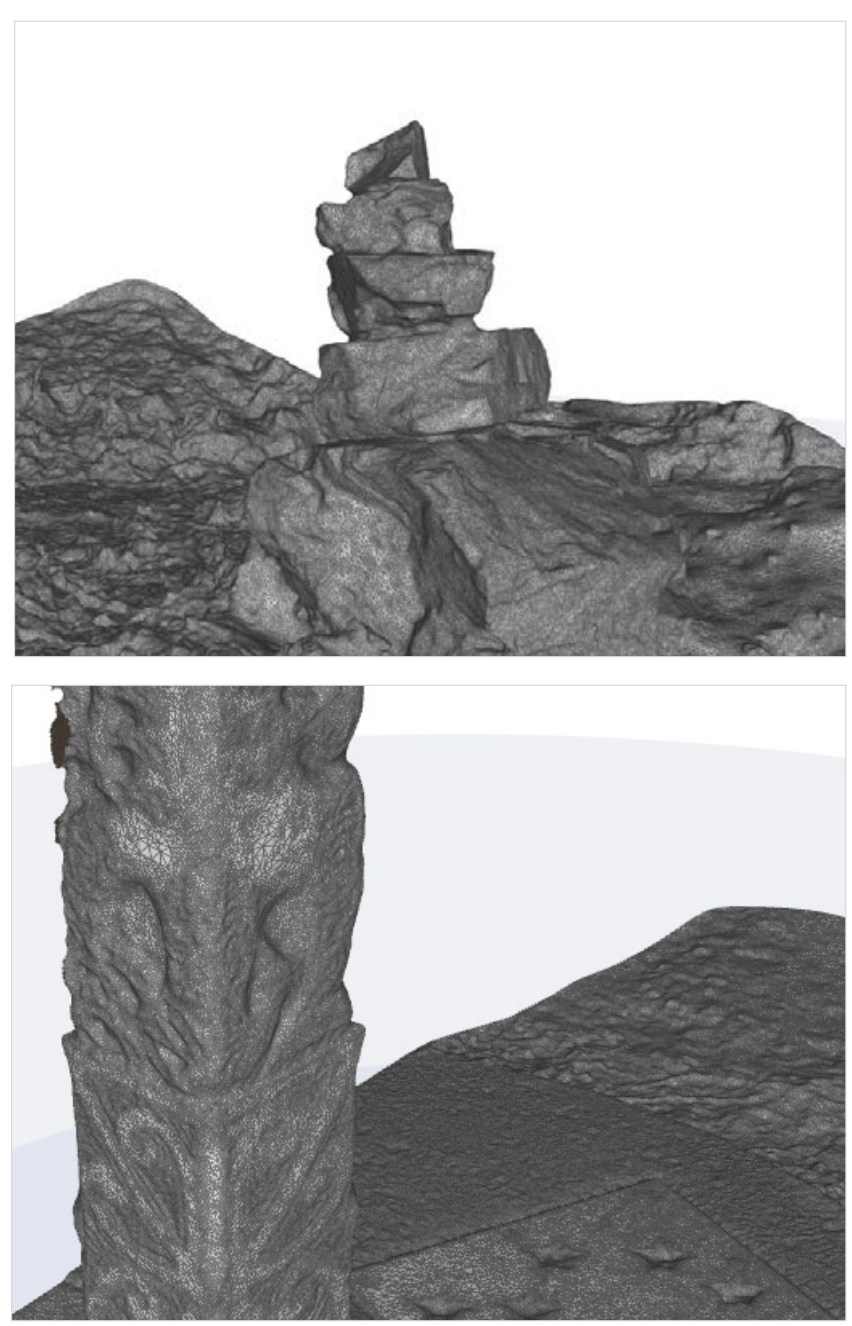
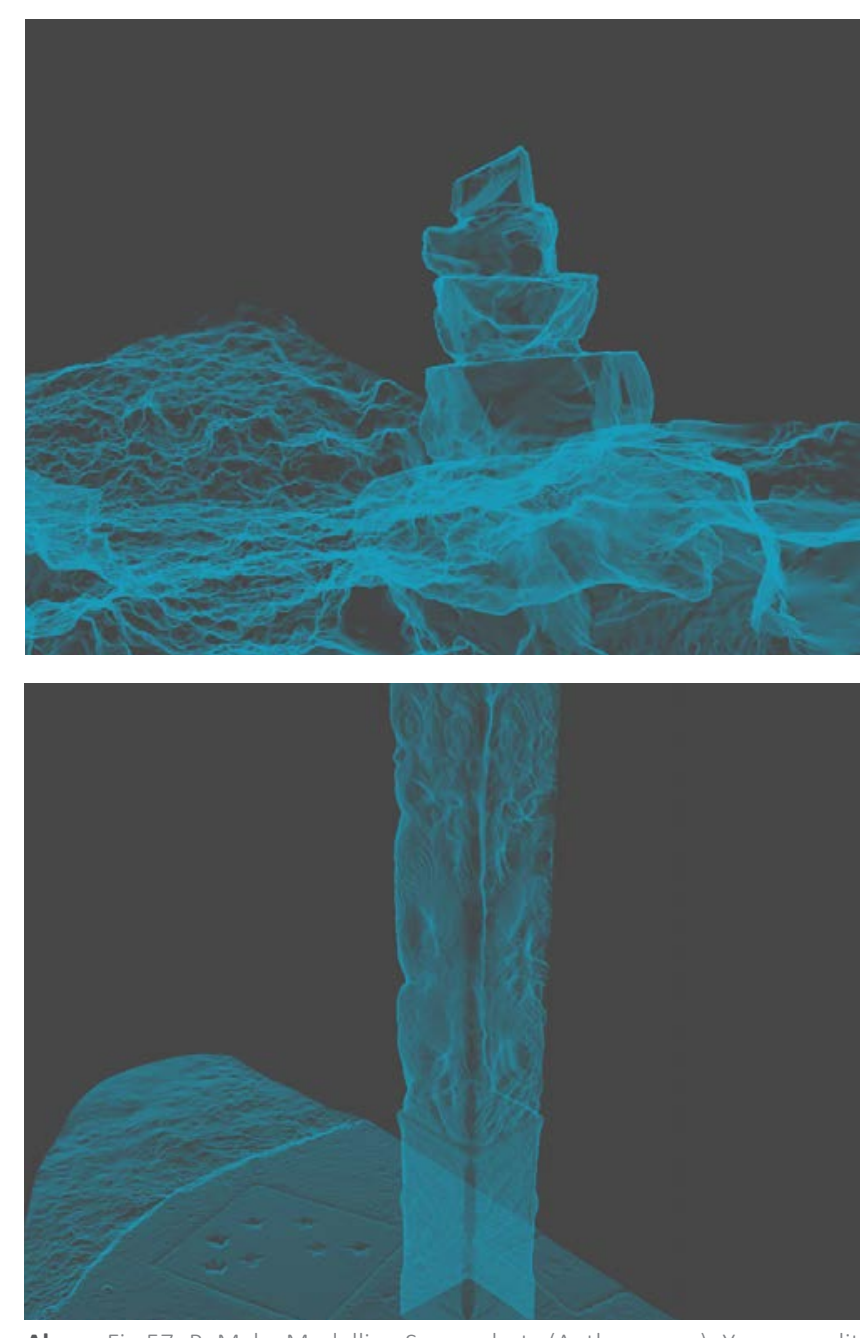

Above Fig 57. ReMake Modelling Screenshots (Authors own). You can edit and rescale objects before exporting to the next stage in the game engine. 
NOT SUITED

\section{UNITY SOFTWARE}

In order to test the varying potential of game environments the research needed to select the best platform that would produce a 3D environment easily navigable, detailed and free to download. Unity (Game development platform) was the first to build up our selected site. The platform exercise tested different ways of creating mesh landscapes and the importing captured photogrammetry. This test was purely based on the ease of operation, time and render/texture quality. Through this testing we came to the conclusion that Unity was able to create environments but through a complicated process compared to other platforms available. The interface was not user friendly and the render quality at the end of a short session was not to the standard we had hoped. In order to make this method more adaptable and approachable for an outsider we decided to move towards Unreal Engine 4.
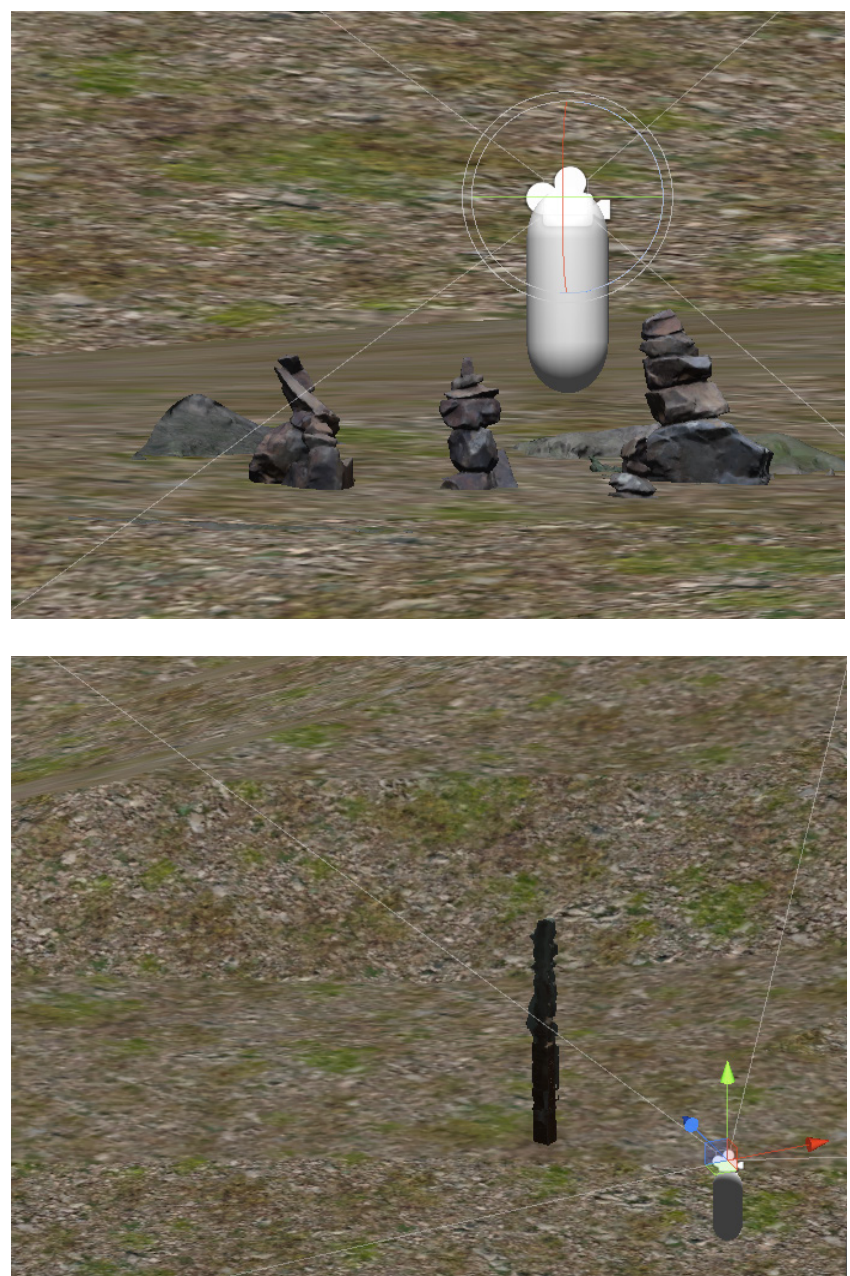

Above Fig 58. Pilot Study Screenshots Unity (Authors own)

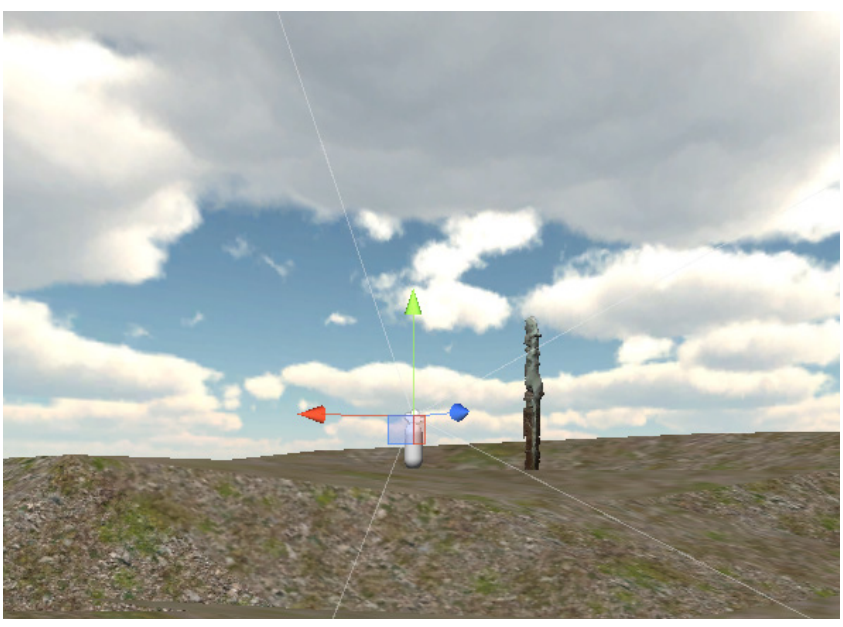

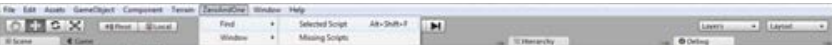

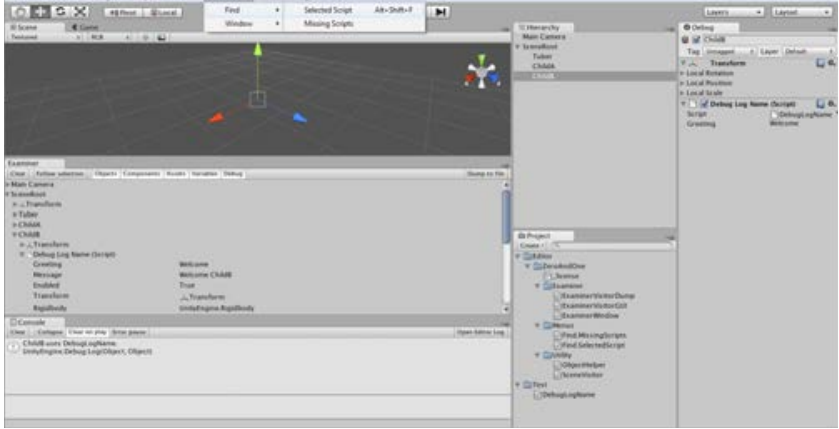

Above Fig 59. Unity Workflow Interface (Authors own). Screenshot of the Unity Interface in use. As shown it is very dated and confusing to navigate. 


\section{PREFERRED OPTION}

\section{UNREAL ENGINE 4}

\section{SOFTWARE}

The gamification software that was selected for use in the research is Unreal Game Engine 4. This program has the potential to analyse the impact of a new design in its surroundings and turn existing environments into digital models with immersive virtual flythrough. The game engine brings an interactive stage with users being able to experience 1st person with overview of context, sightlines, and buildings/object heights in relation to the viewport. The scale of imported models can be adjusted to suit including photogrammetry models. The user interface for this software was a lot easier to navigate and work in a similar way to grasshopper with plugins and scripting included.

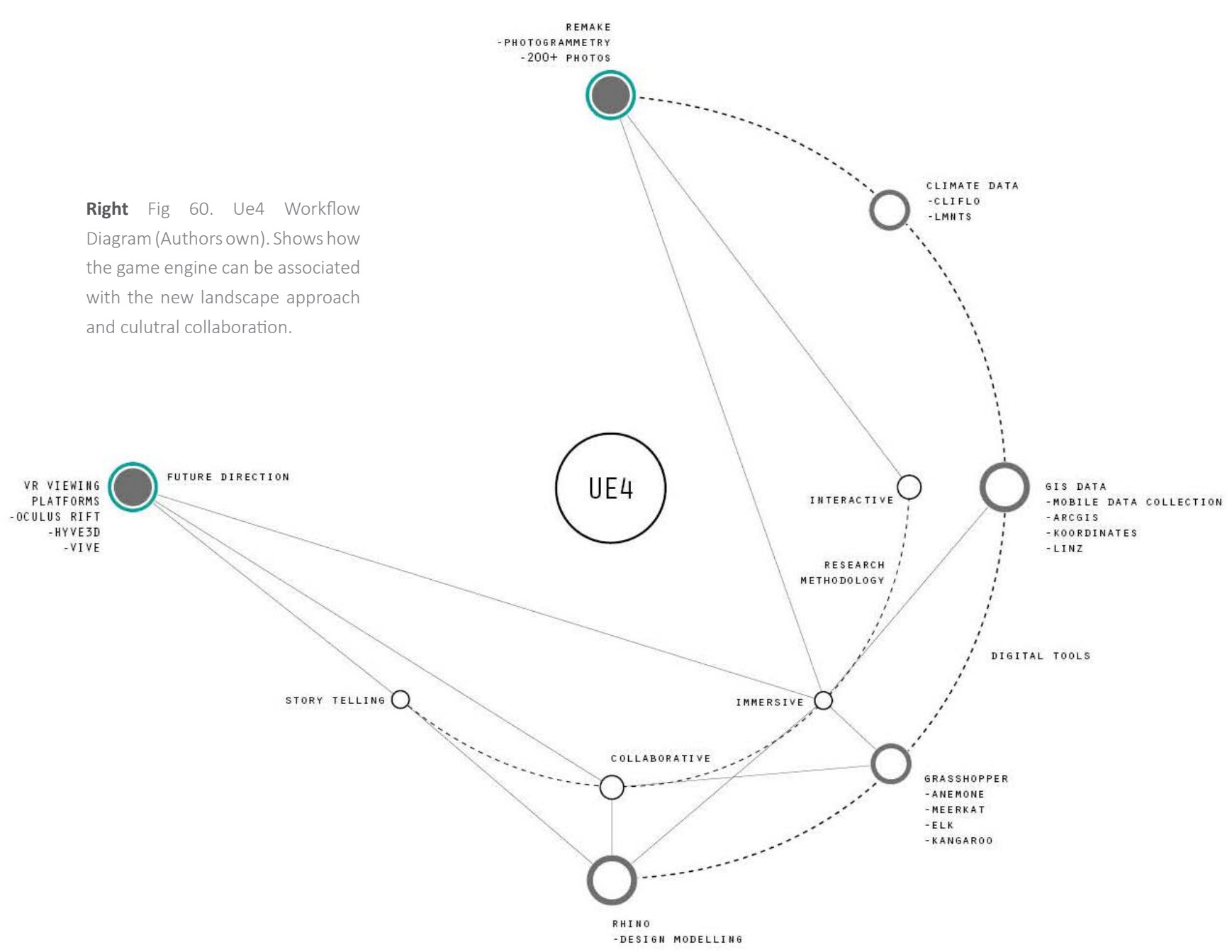




\section{RHINO \& GRASSHOPPER SOFTWARE}

Some of the simulations and designing of spaces were implemented through the use of Rhino and grasshopper. In order for any simulation to take place a surface needs to be created as a base that can then be scalable and defined as close as possible to the true landform subject. As shown, in some of the test studies below there are many ways in which you can create a landscape model, all vary in quality, ease and definition. To achieve the best and most simple to devise landscape model the terrain mesh model was selected as the chosen process where contours from a scaled DWG are extruded to $1 \mathrm{~m}$ intervals and a surface is then patched joining them as a 3D object where you can increase definition based on more modelled points.

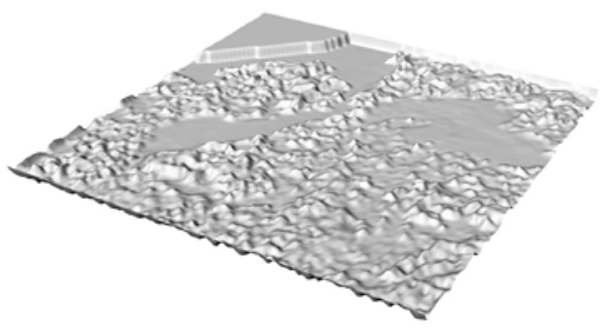

IMAGE SAMPLING

colour hue aerial extrusion

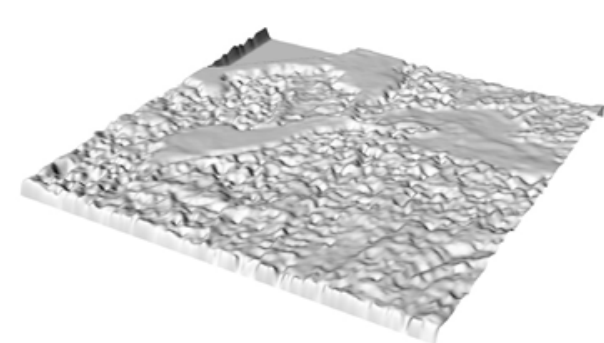

I MAGE SAMPLING

black and white aerial extrusion

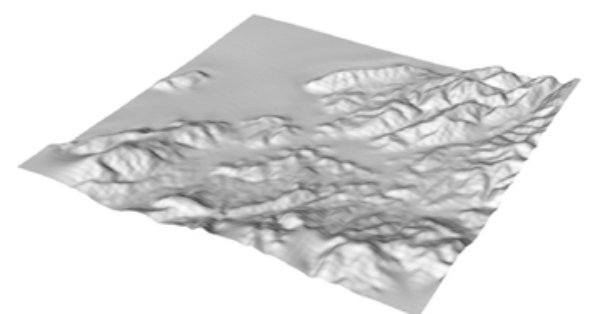

IMAGE SAMPLING

DEM heightmap extrusion

Fig 61. Terrain Surface Variations (Authors own)

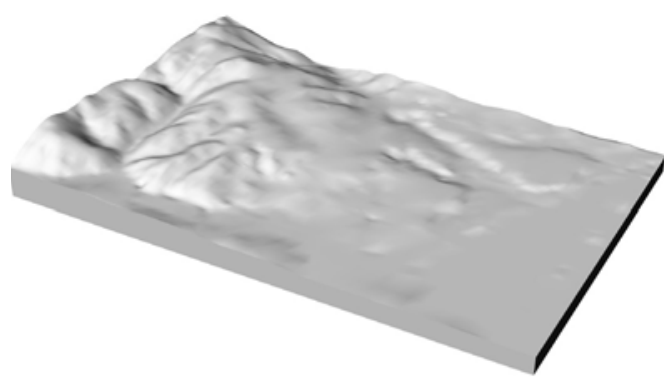

TERRA IN POLYSURFACE easy grasshopper contour polysurface

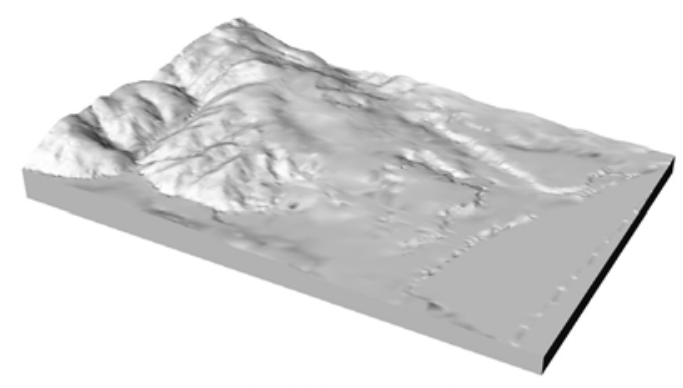

TERRA IN POLYSURFACE complex grasshopper contour polysurface

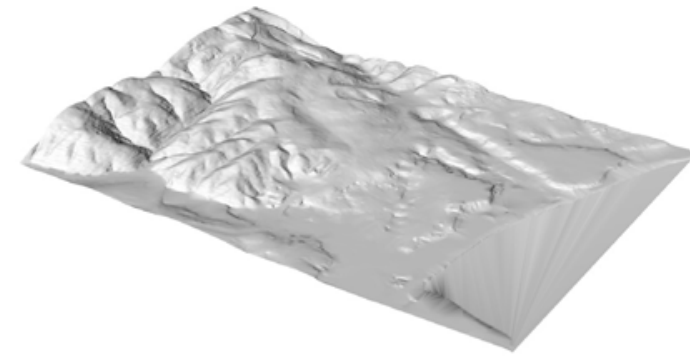

TERRA I N MESH

simple grasshopper contour mesh 


\section{GRASSHOPPER SCRIPTS}

At the beginning of the research there was very little digital resources in the form of scripting available for the field of landscape architecture. The grasshopper scripts used to create $3 \mathrm{D}$ forms and test various simulations were all based off architecture tutorials and needed to be refined and simplified to align with the research landscape approach, whilst keeping in mind that this technique should be accessible for fellow landscape designers to access. In the process of refining these scripts, videos of these workflows were captured with future intentions of releasing a YouTube channel based around digital landscapes. These videos show the scripting process and are easy to understand, quick tutorials on how to create high definition 3D surfaces from contours and images, water runoff and gradient pathfinding are all included. These valuable digital analysis tools are a great way to test designs, simulate climate conditions and allow for a new perspective of site that differs from the conventional way landscape architects typically engage with a project.
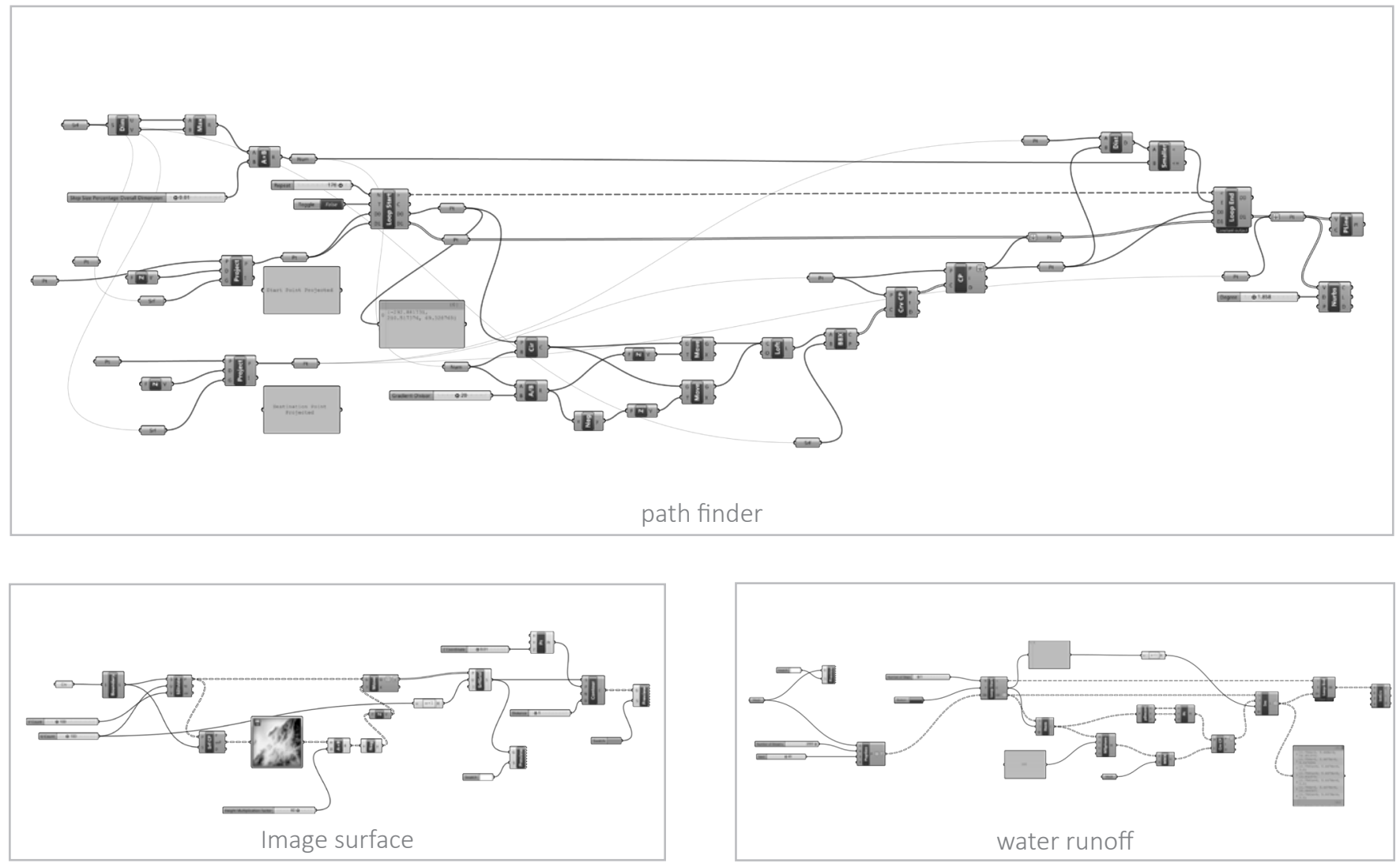

Right Fig 62. Refined Grasshopper Screenshots (Authors own). Refined grasshopper scripts used to simulate elements such as water runoff and tsunami flow etc. Refer to appendix for enlarged versions of scripts. 


\section{DESIGN SIMULATION}

One of the primary advantages of simulating designs is that they are able to provide users with a way to give practical feedback when designing real world systems. The designer is able to determine the correctness and efficiency of a design before the system is actually constructed. Consequently, the user may explore the merits of alternative designs through an interactive and immersed experience without actually physically building the system. "Participants learn to train decision-making and acquire analytical skills as the simulation goes on" (Maidment \& Bronstein, 1973).
During the design experimental phase, the research presented a range of design options in a simpler form that left out elements such as plant selection and the placement of existing walkways. By mimicking the behaviour of the designs, the simulation is able to provide the research with new realistic scenarios that can then interact with real site information pertaining to the correctness and efficiency of each design. The research could draw a more detailed and interactive response for iwi members and allow them to see the site in an immersive environment. After carefully weighing the potential of each design, elements of the best design may then be selected with enough evidence to prove its worthiness.
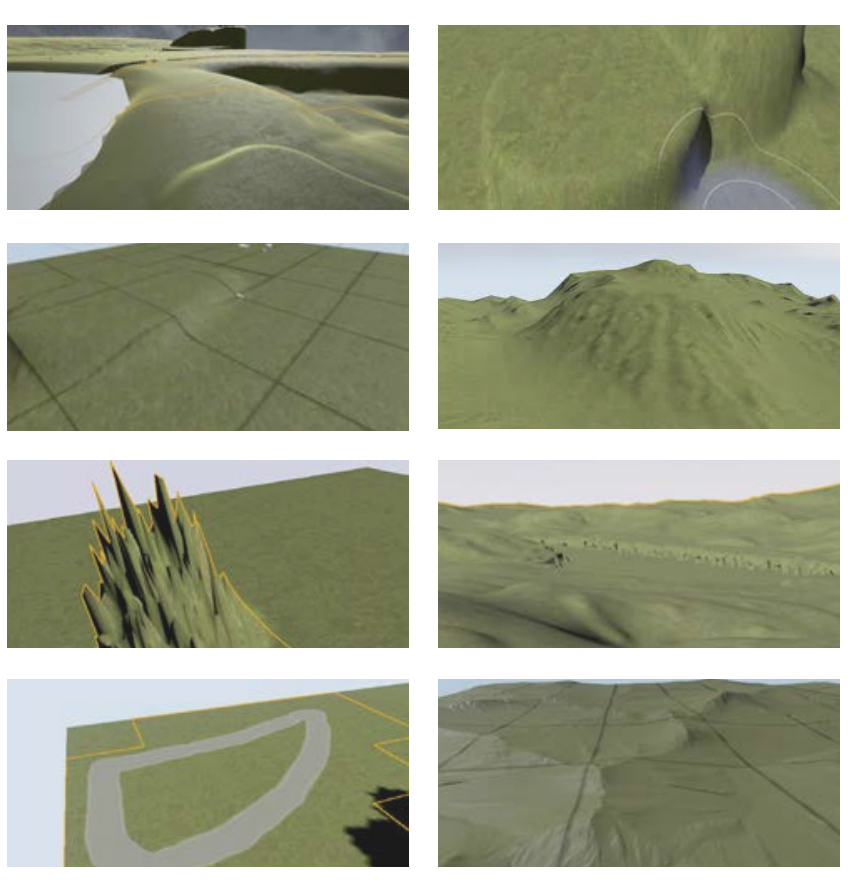

Above Fig 63. Design Experiments Ue4 (Authors own). Screenshots of some of the landscape designs that can occur when experimenting in Ue4. 


\section{GAME INTERFACE UE 4}

When designing the game interface it was important to firstly predict what the user wanted to know and give them that information in the simplest form. Because this system was designed for a specific group of people with the intention of being used by a variety of different users (age, gender etc.)

it needed to be simple, easy to use and navigable. The UI created is based on the interface of a phone sized app in order to be familiar and repetitive in terms of options. This interface helps to communicate a clear menu system and has only been developed for four select uses at this stage.
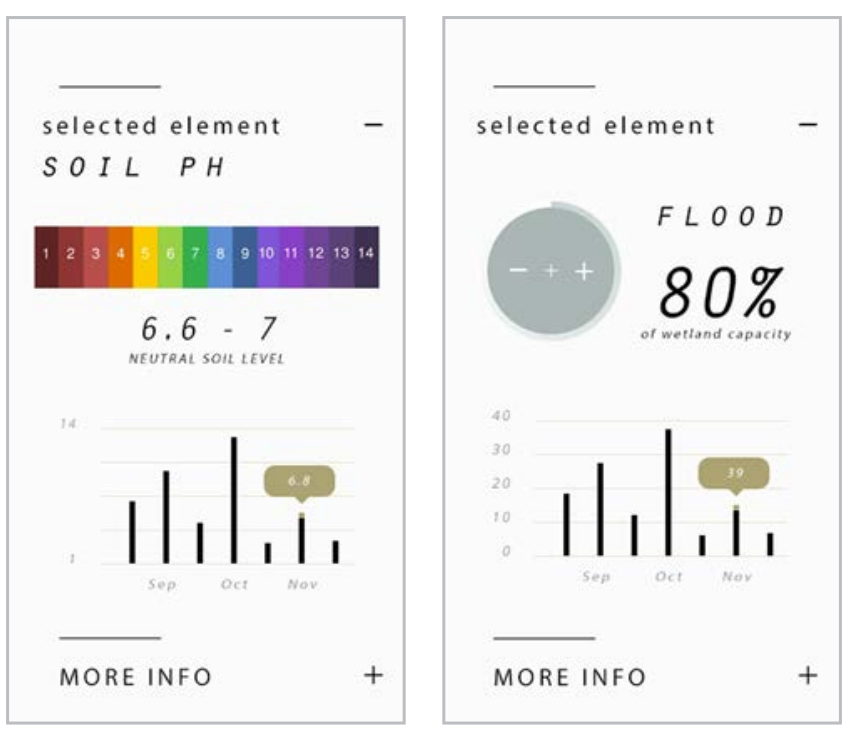

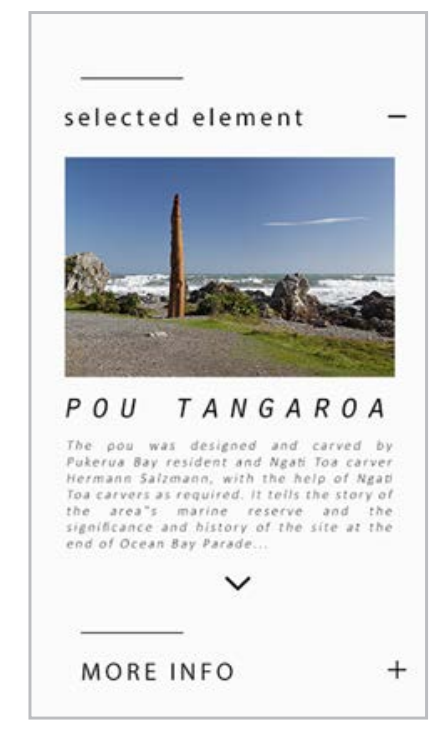

Above Fig 64. Game Interface Ngāti Toa (Authors own). Screenshots of the designed user interface that was intended for use in the interactive game environment. 


\section{CLIMATE S IMULATIONS UE 4}

The benefits of climate simulations is that they permit system designers to study problems at varied levels of abstraction. Simulations can be used as an effective means for teaching or demonstrating concepts to others who may not have the same understanding as the designer. By approaching a project at a higher level of abstraction, the designer is better able to understand the behaviours and interactions of all of the high level inputs and therefore execute a more responsive approach to help mitigate or extend through design.

Through Unreal Engine 4 and photogrammetry, the intelligent use of computer graphics and animation could portray design ideas and implications dynamically to iwi participants. The intent of these digital tools developed a strong relationship between all of the system's components and helped in the process of communicating a more meaningful understanding of the system's nature and how it could be of help.

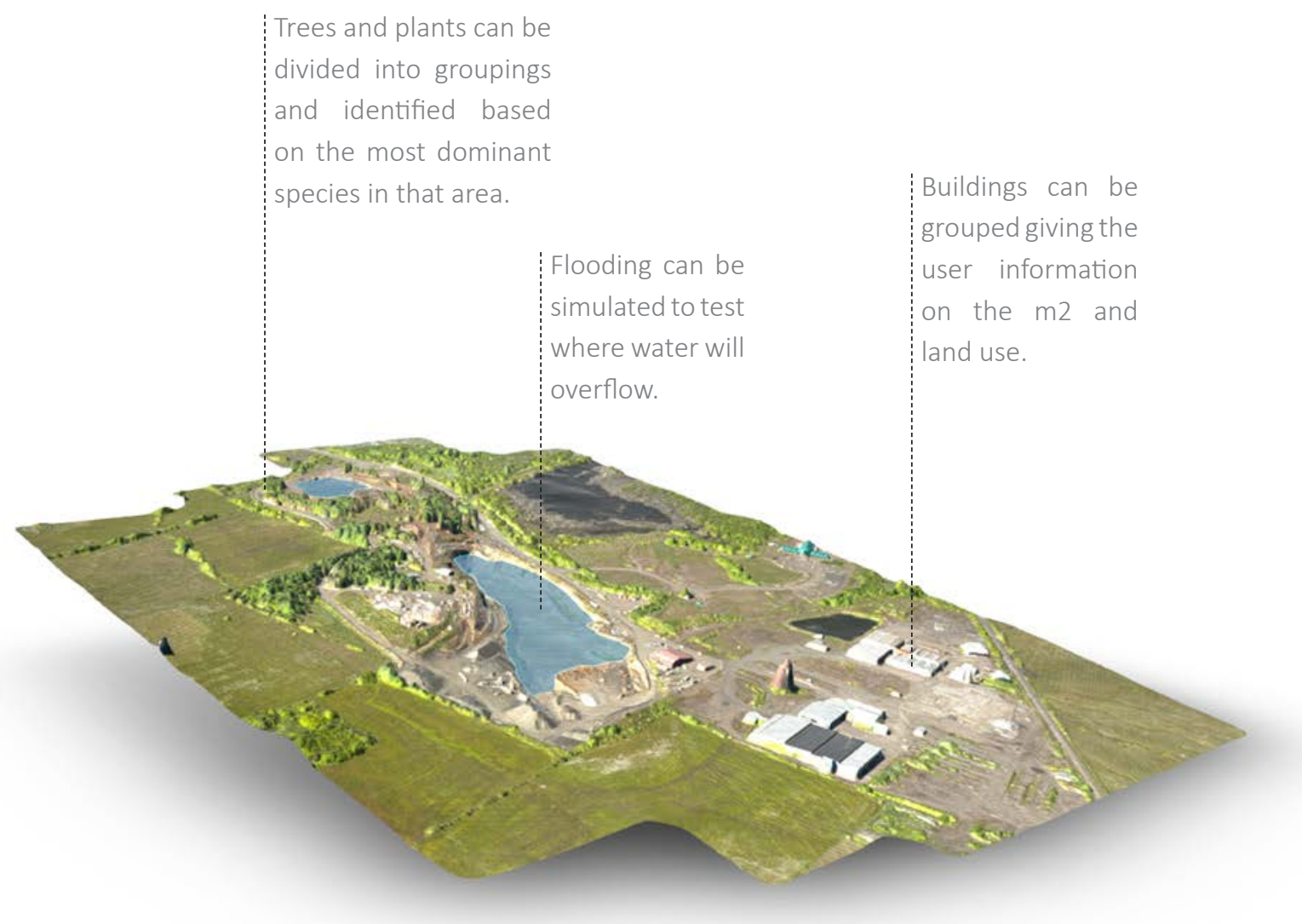

Above Fig 65. Climate Simulation Aerial Pilot Study (Authors own). Screenshot of a test subject used to test climate simulations - Quarry mine project. 
This part of the research was better equipped to counteract the complexity of the overall site risks and formed a "top-down" technique, by working at this higher level of abstraction. The research was able to rapidly produce pilot studies for the purpose of analysing feasibility and practicality. "We can dramatically bring the impacts of climate change home to people by 'making climate change personal' through realistic views of their familiar landscape under future scenarios" (Sheppard, Shaw, Flanders, \& Burch, 2008).

A pilot study was conducted on an open source photogrammetry model to test whether the real world implications we were wanting to test, such as climate conditions, would interact in a game designed environment. These simulations gave us an initial understanding of impacts and risks with a view to local response and mitigation. Random data was loaded into the game engine model purely to test climate conditions to see how disasters such as flooding and sea level rise would interact in 3D. Because of the large scale size of the captured photogrammetry model, the model's definition can be seen as fairly low quality when in first person view.

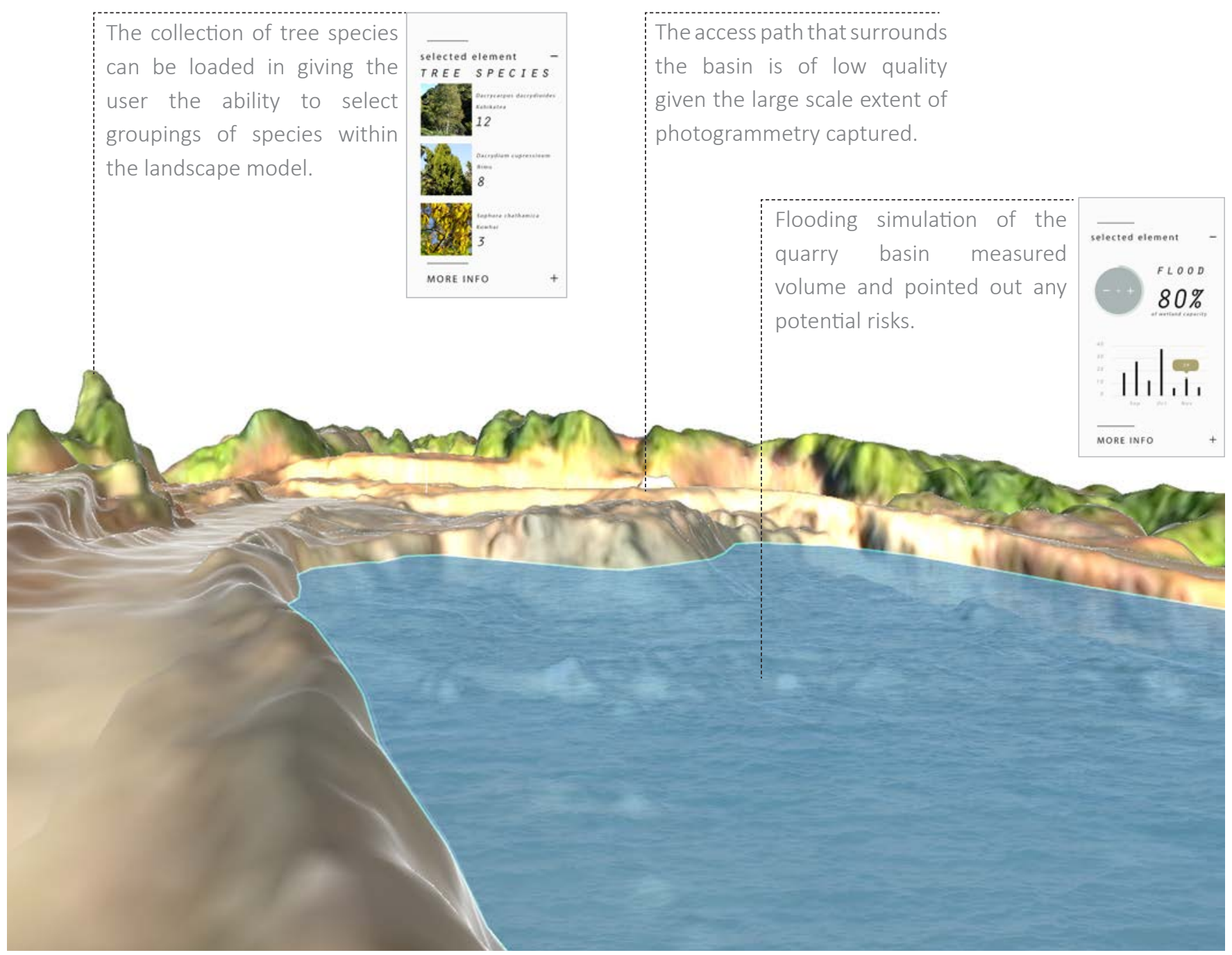

Fig 66. Climate Simulation 1st Person Pilot Study (Authors own) 


\section{INTERACTIVE STORYTELLING UE 4}

Interactive storytelling combines ludology, narratology and game design to form interactive entertainment development methodologies. Interactive entertainment experiences allow the player to witness data as navigable, participatory, and in real-time.

Interactive storytelling is a form of digital entertainment in which the storyline is not predetermined. Through this research the setting and situation in which the narrative must address have been created and have been made obvious. The user experiences the 3D environment through their own personal interaction within the game. Usually the architecture of an interactive storytelling program includes a drama manager, user model, and agent model to control. However in this research the gameplay was kept simple and the characters storyline was used to facilitate more of an education tool to inform users of elements when selecting objects within the field of play.

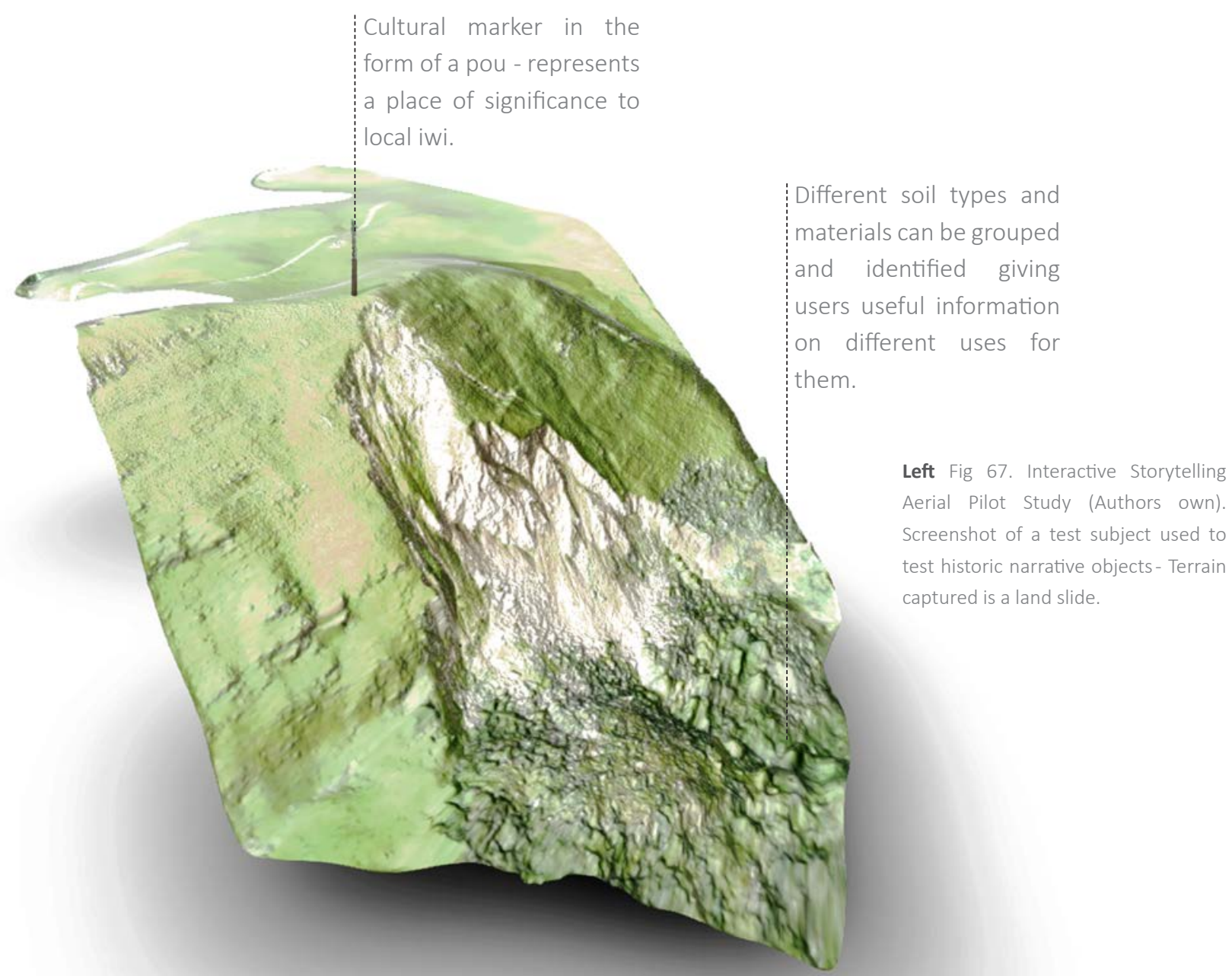


The aim is to transport the user through play in the environment using their visual and auditory senses drawing upon defined areas of the 3D environment to lure players in that direction. The interactive narrative design is seen as being successful every time a user selects an object and enters a new window to gain a new site understanding.

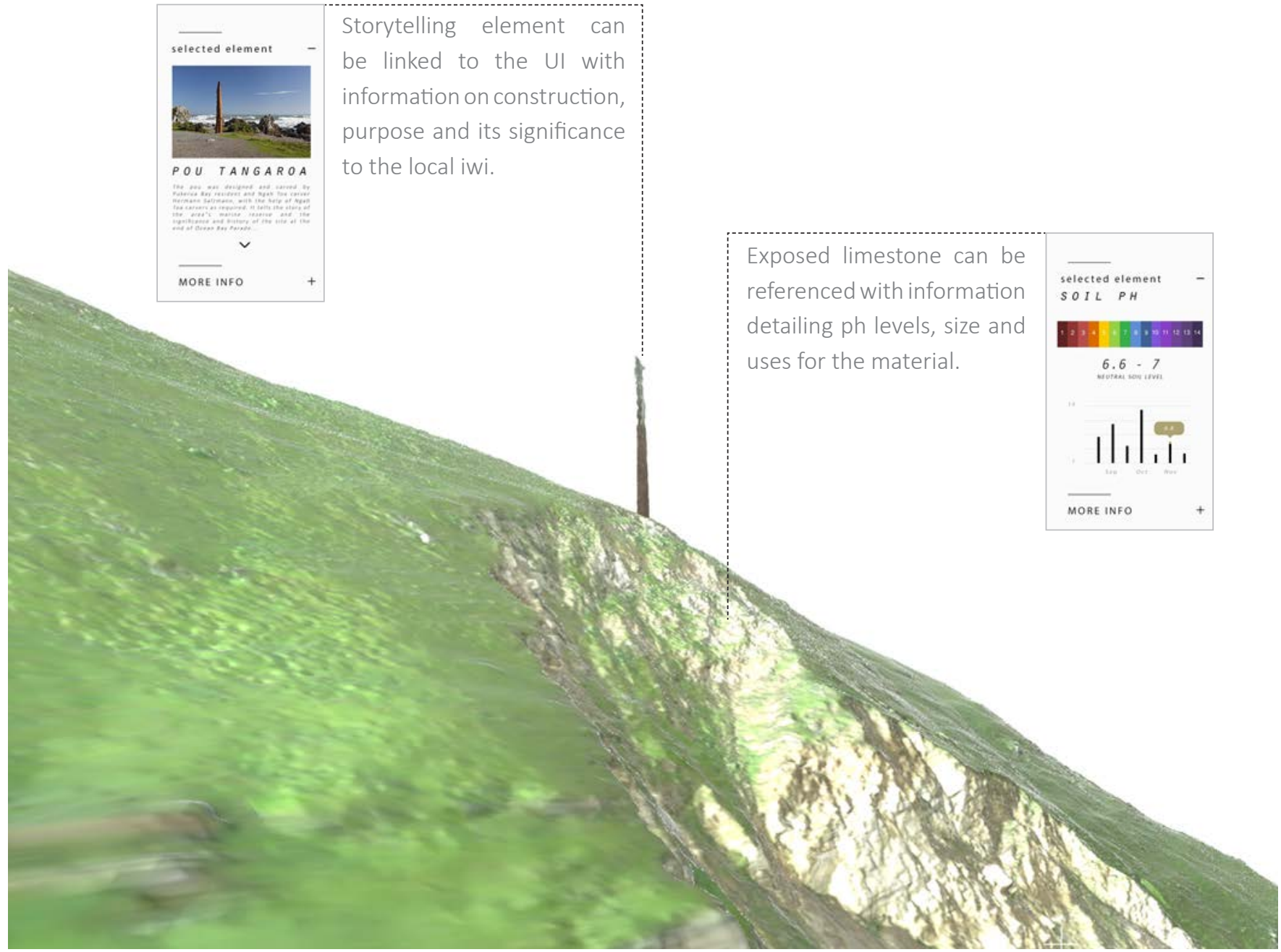

Above Fig 68. Interactive Storytelling 1st Person Pilot Study (Authors own)

Screenshot of a pilot study used to test the integration of an historic object. 


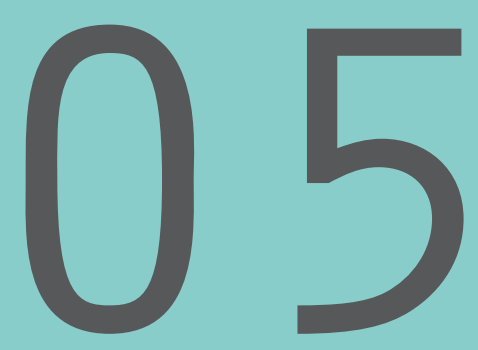

SITE ANALYSIS

This section looks at what exisits in Takapuwahia and places it within its wider context analysing how climatic and ecological factors imapct site.

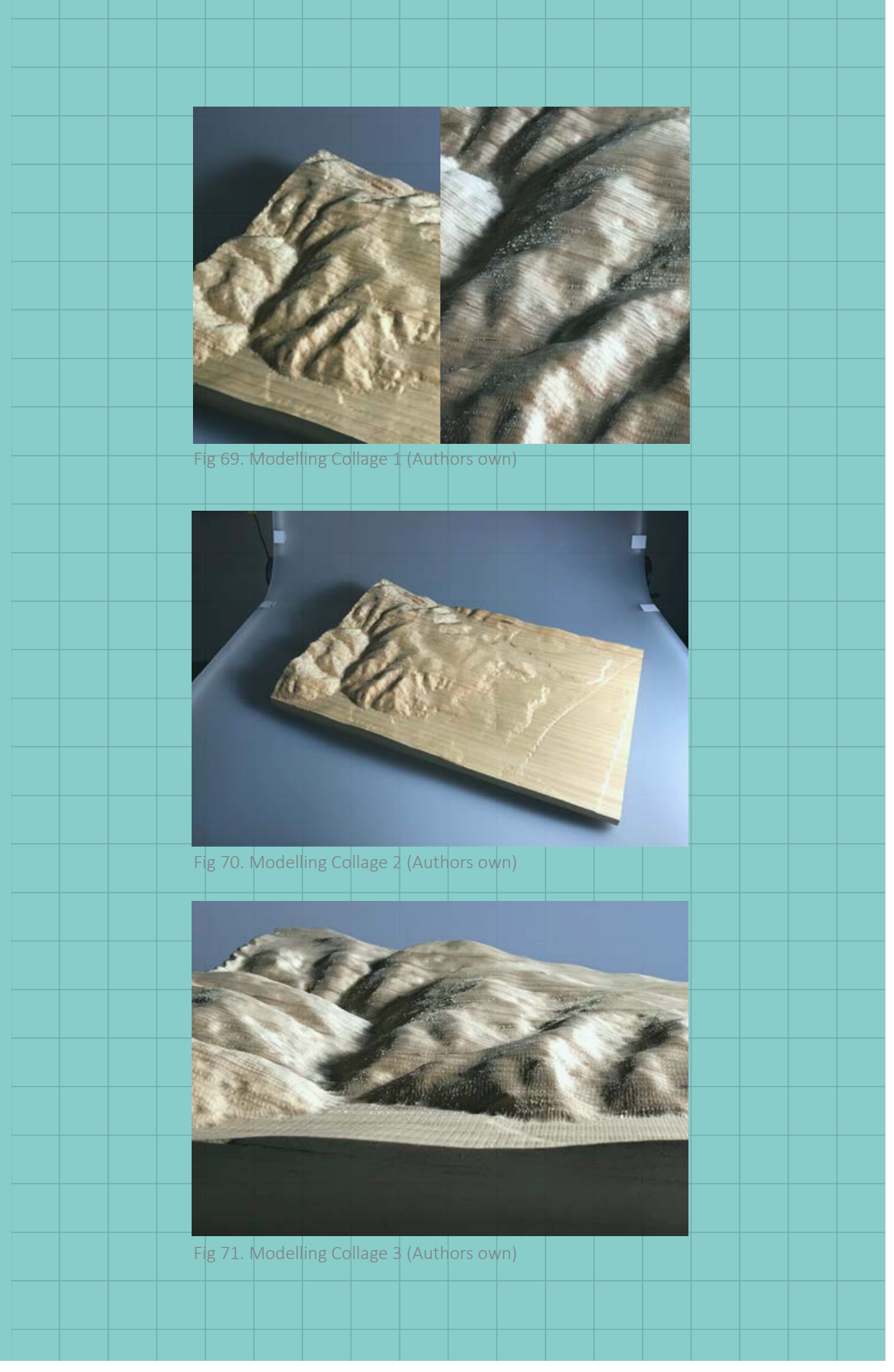




\section{LAND SURVEYING}

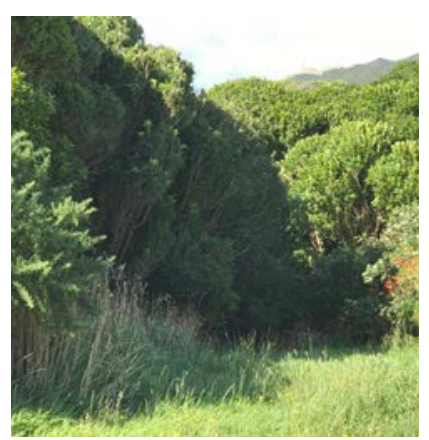

B U S H

Fig 72. Land Surveying (Auhtors own) Exisitng Bush

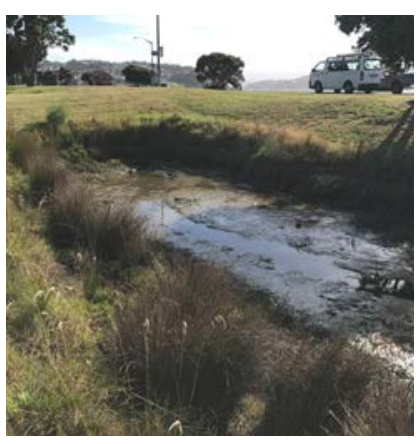

WET LAND

Fig 73. Land Surveying Exisitng Wetland (Authors own

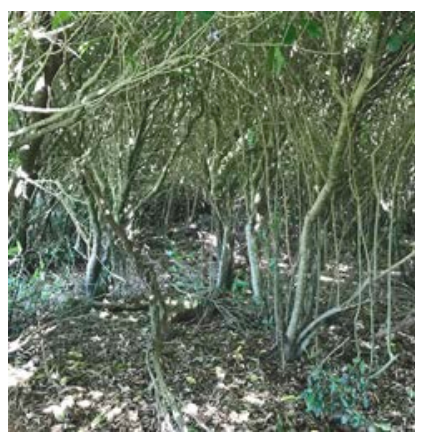
MAIN FLORA SPECIES MAIN FLORA SPECIES

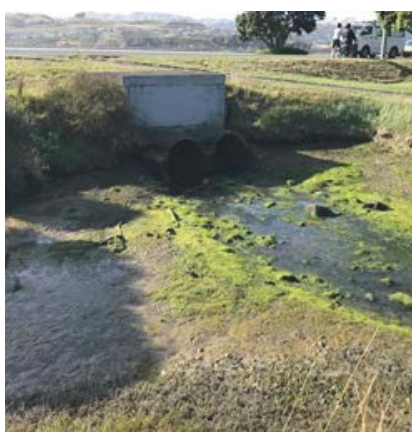

22 MAIN FLORA SPECIES
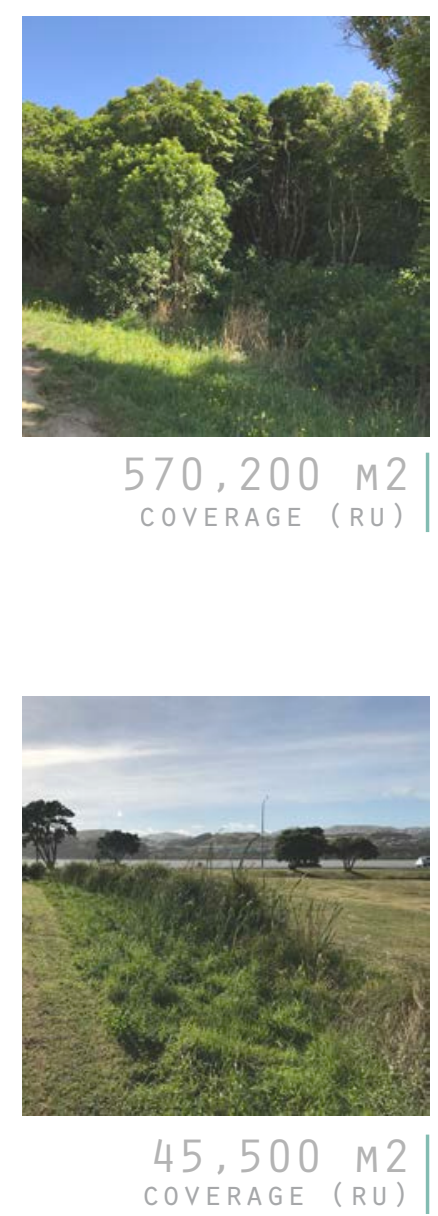

$570,200 \quad M 2$
COVERAGE (RU)

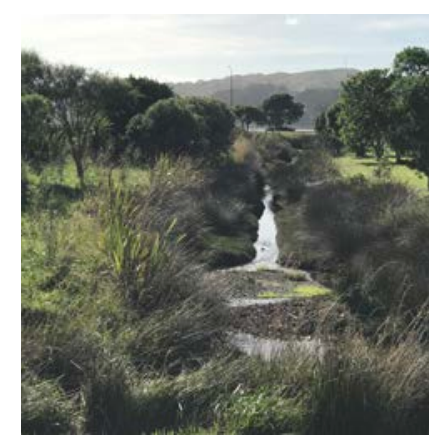

STREAM

Fig 74. Land Surveying

Exisitng Stream (Authors own)

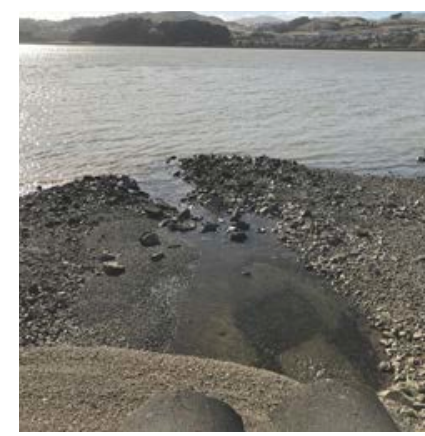

COASTAL

Fig 75. Land Surveying Exisitng Coast (Authors own)

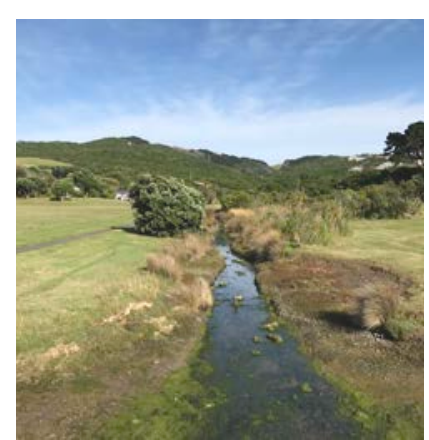

12

MAIN FLORA SPECIES

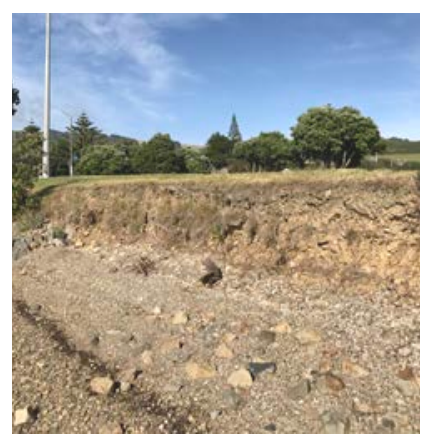

MAIN FLORA SPECIES

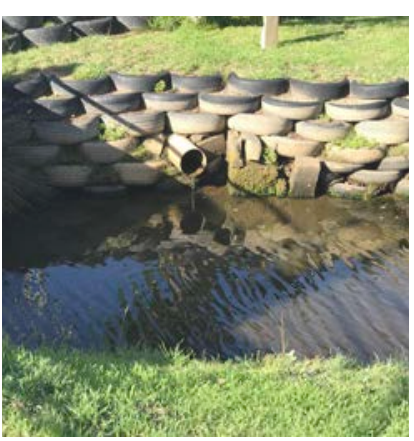

10,050 M2

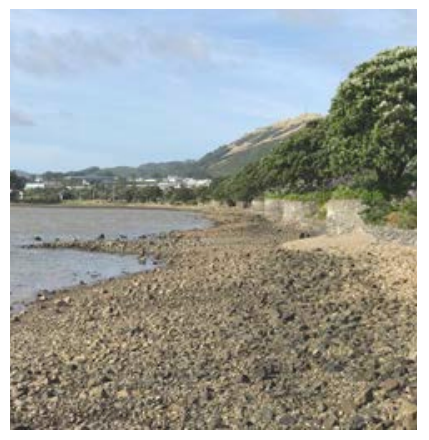

15,000 M2 


\section{WINDFLOW PROJECTIONS}
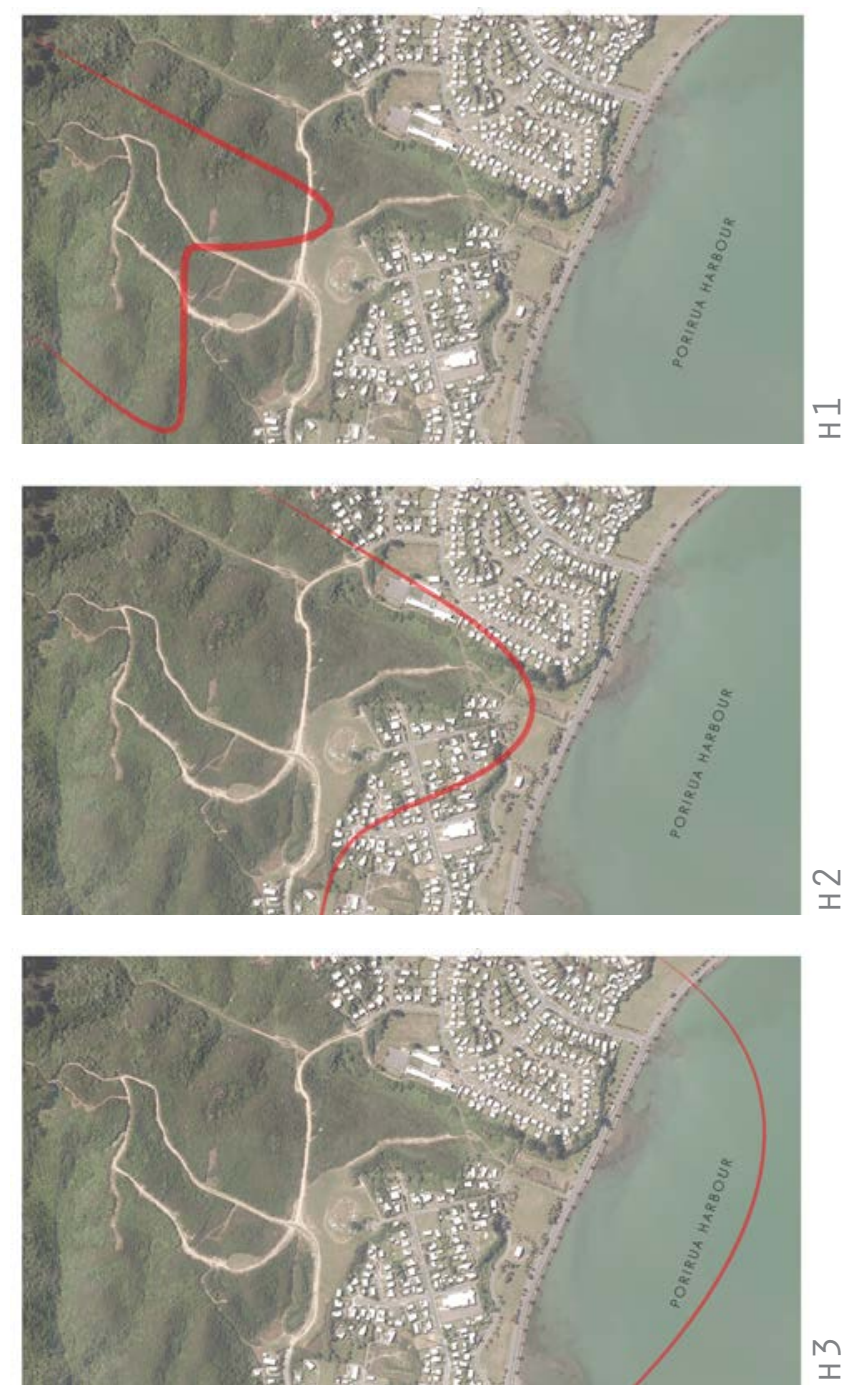
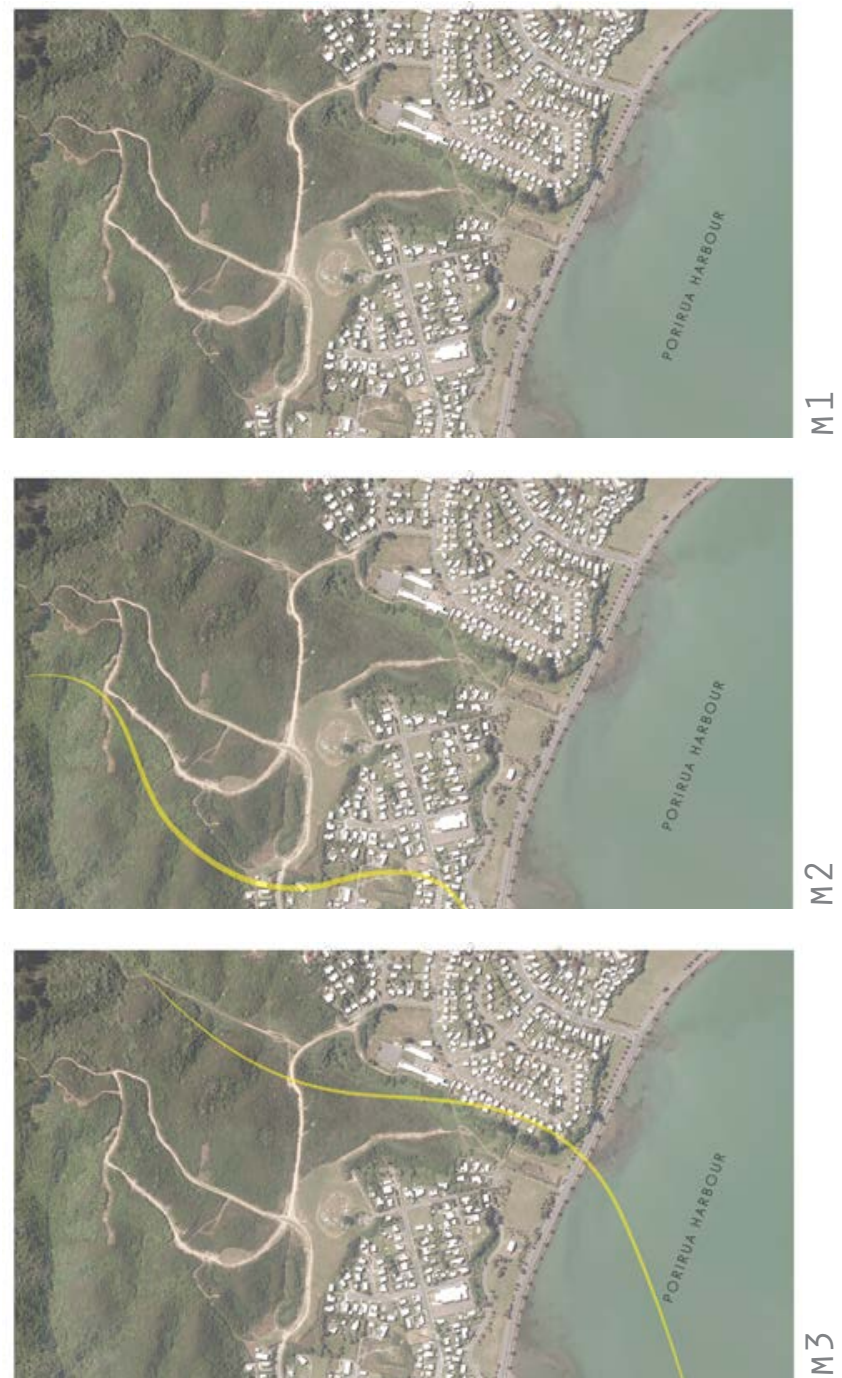
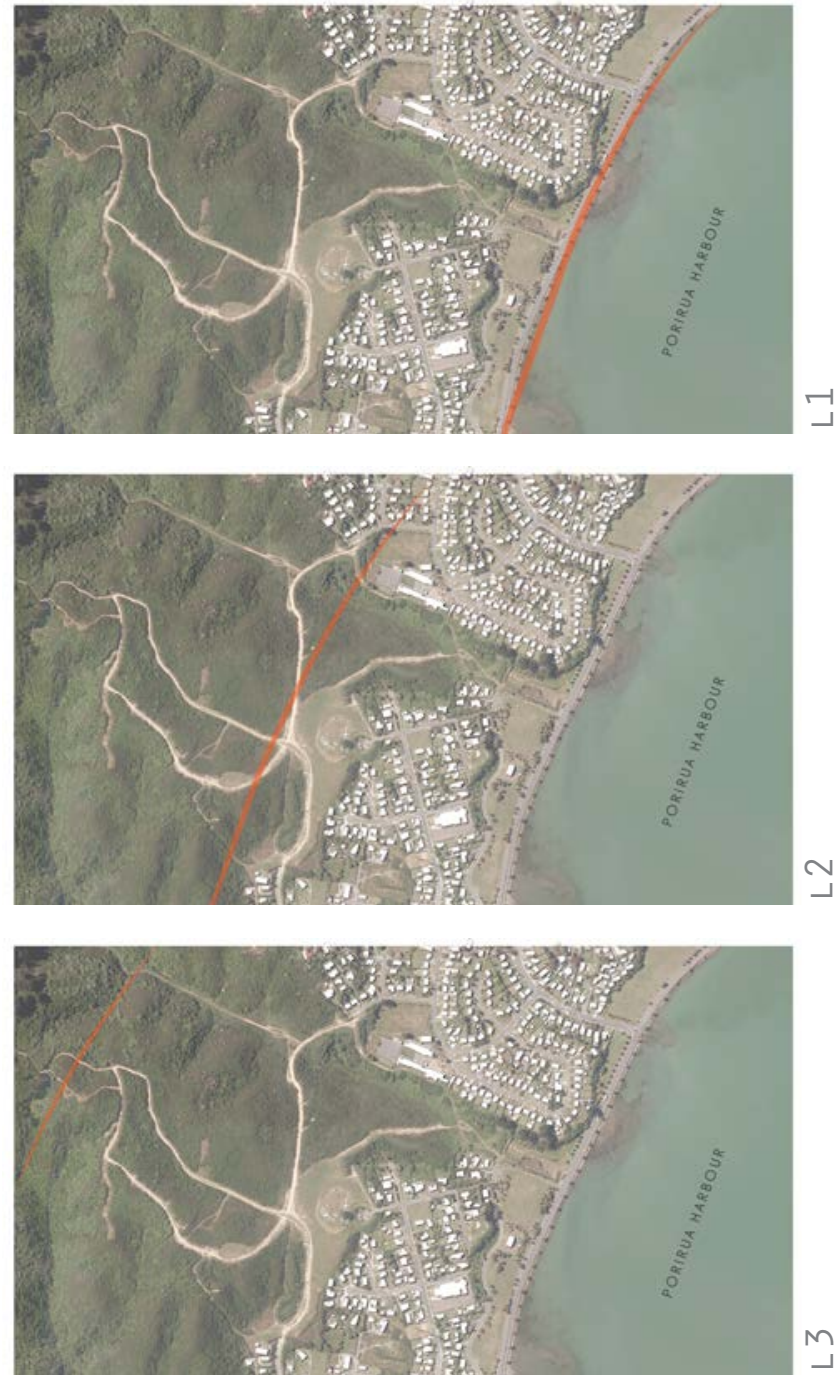

Above Fig 76. Windflow Scenario Model Projections (Authors own).

Screenshots of projection videos that showed mock scenarios and windflow simulations on top of the 1:1000 model. 
SITE MODEL

SOLAR PROJECTIONS
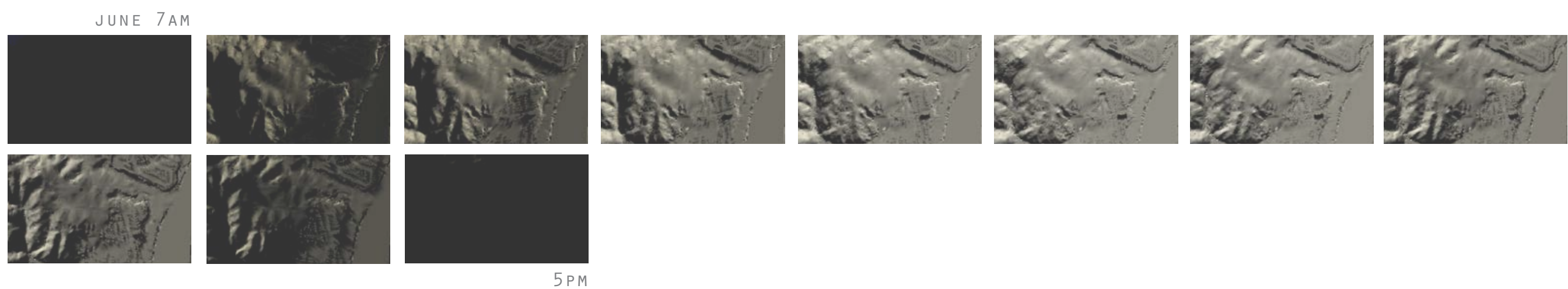

DECEMBER 4 AM
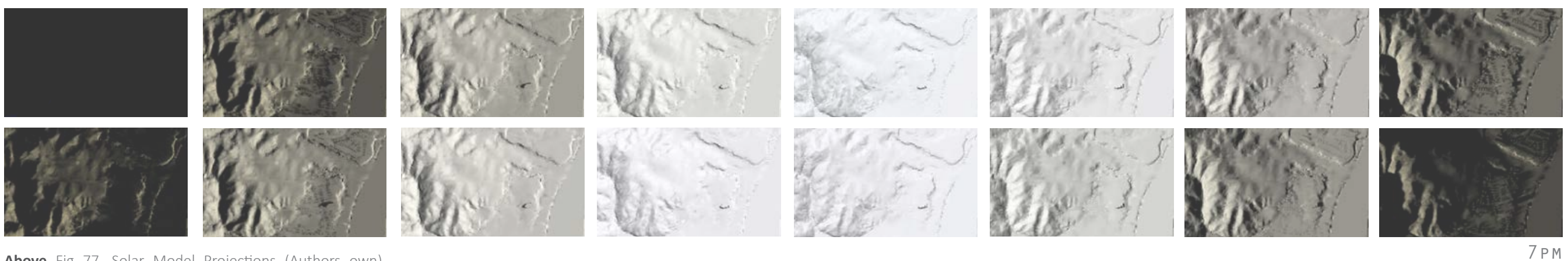

Above Fig 77. Solar Model Projections (Authors own). Photos of the solar projections overlayed on the site model. 


\section{MACRO \\ WATER RUNOFF}

MACRO CLIMATE

ANALYSIS (WATER)

water runoff (rainfall), tsunami zones, flood prone areas

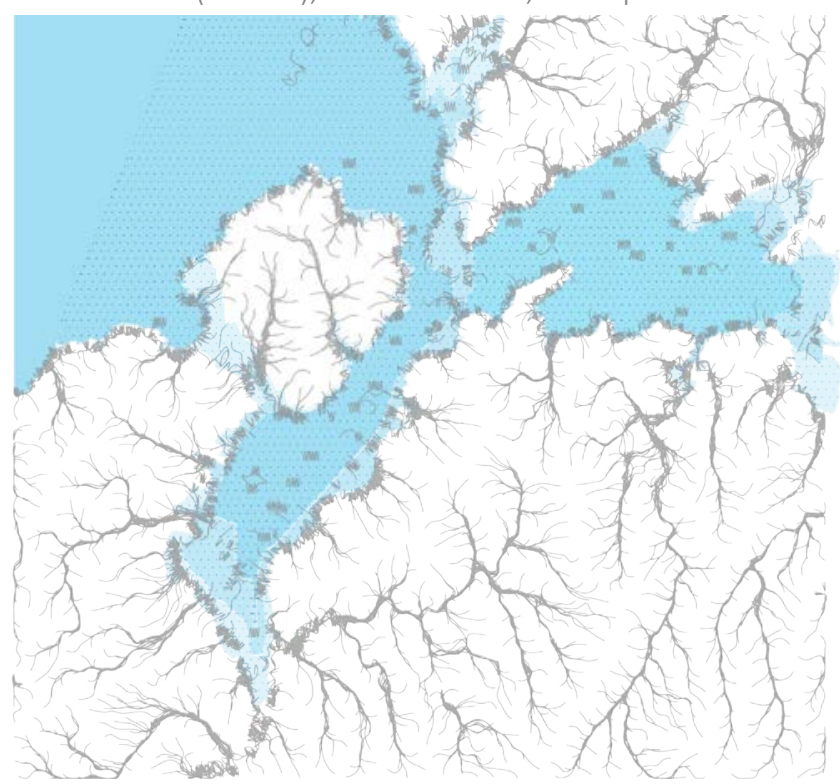

Fig 78. Macro Water Runoff Loop (Authors own)
LOOP 01

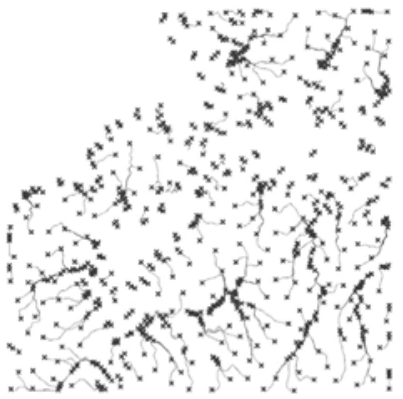

LOOP 300

sis

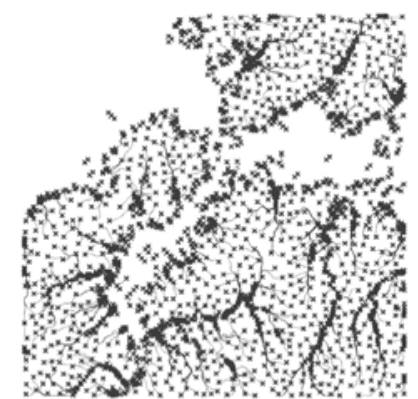

LOOP 1000
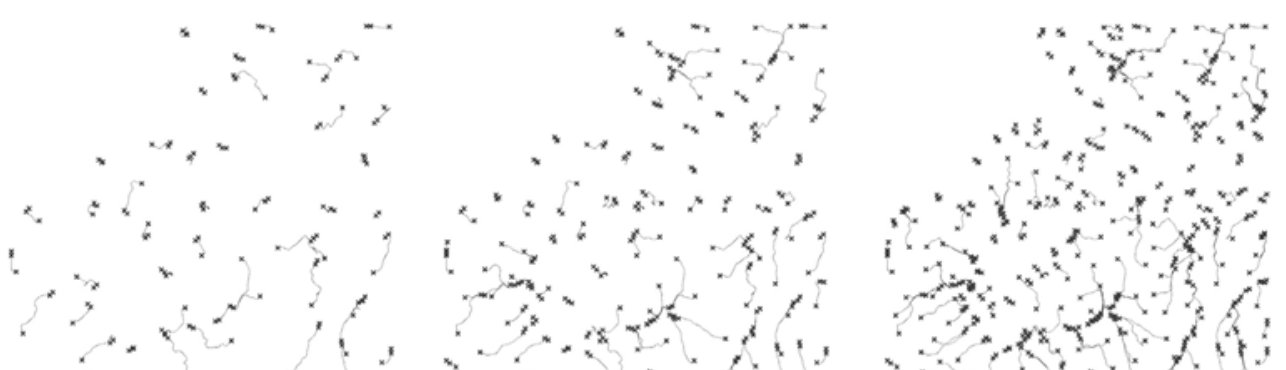

LOOP 50

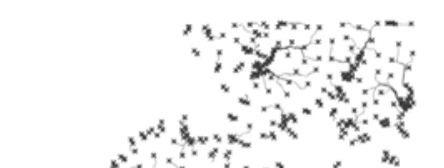

and
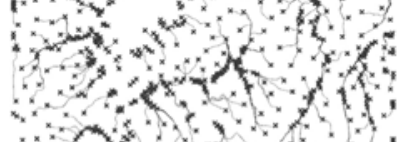

LOOP 400

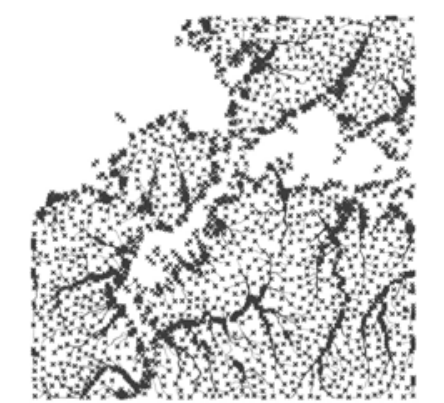

LOOP 1250

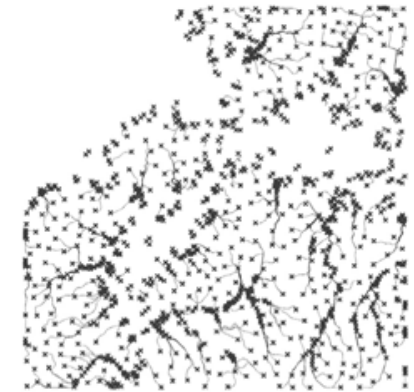

LOOP 500

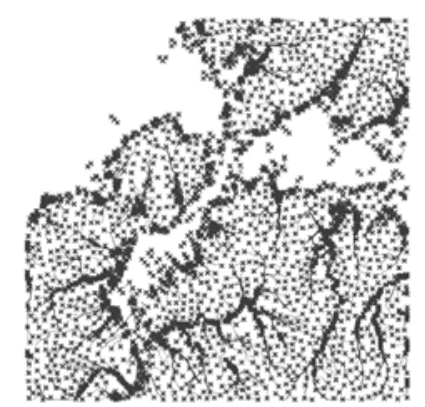

LOOP 1500

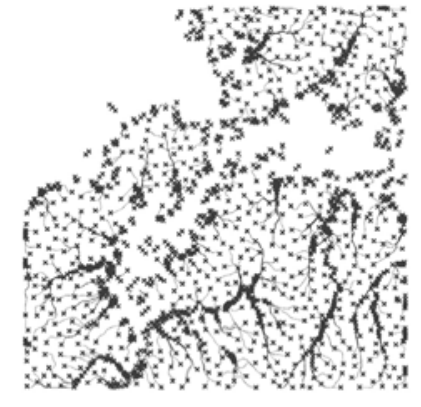

LOOP 750

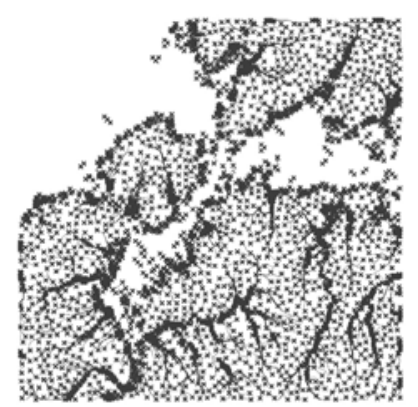

LOOP 1750 


\section{MICRO \\ WATER RUNOFF}

I N I T I A L

RANDOM

POINT CLOUD

major structure of

landscape is evident

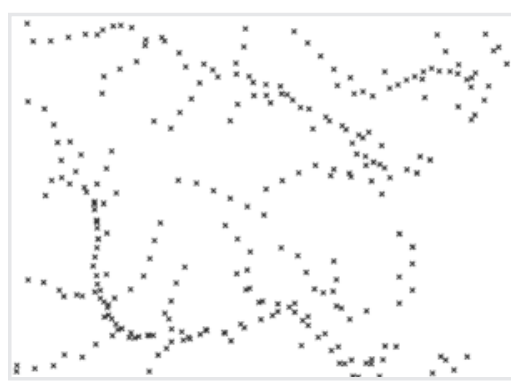

LEAD ING

POINTS AFTER

50 LOOPS

most points have

settled in the major

water courses

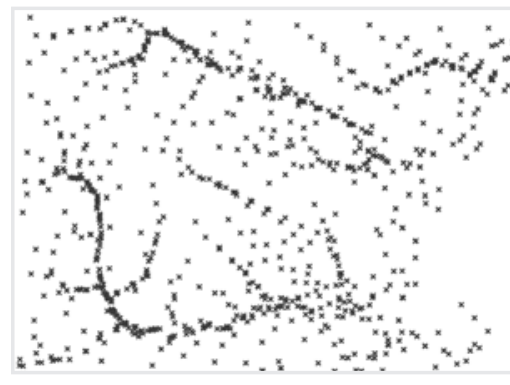

MICRO CLIMATE ANALYSis (WATER)

water runoff (rainfall), tsunami zones, flood prone areas

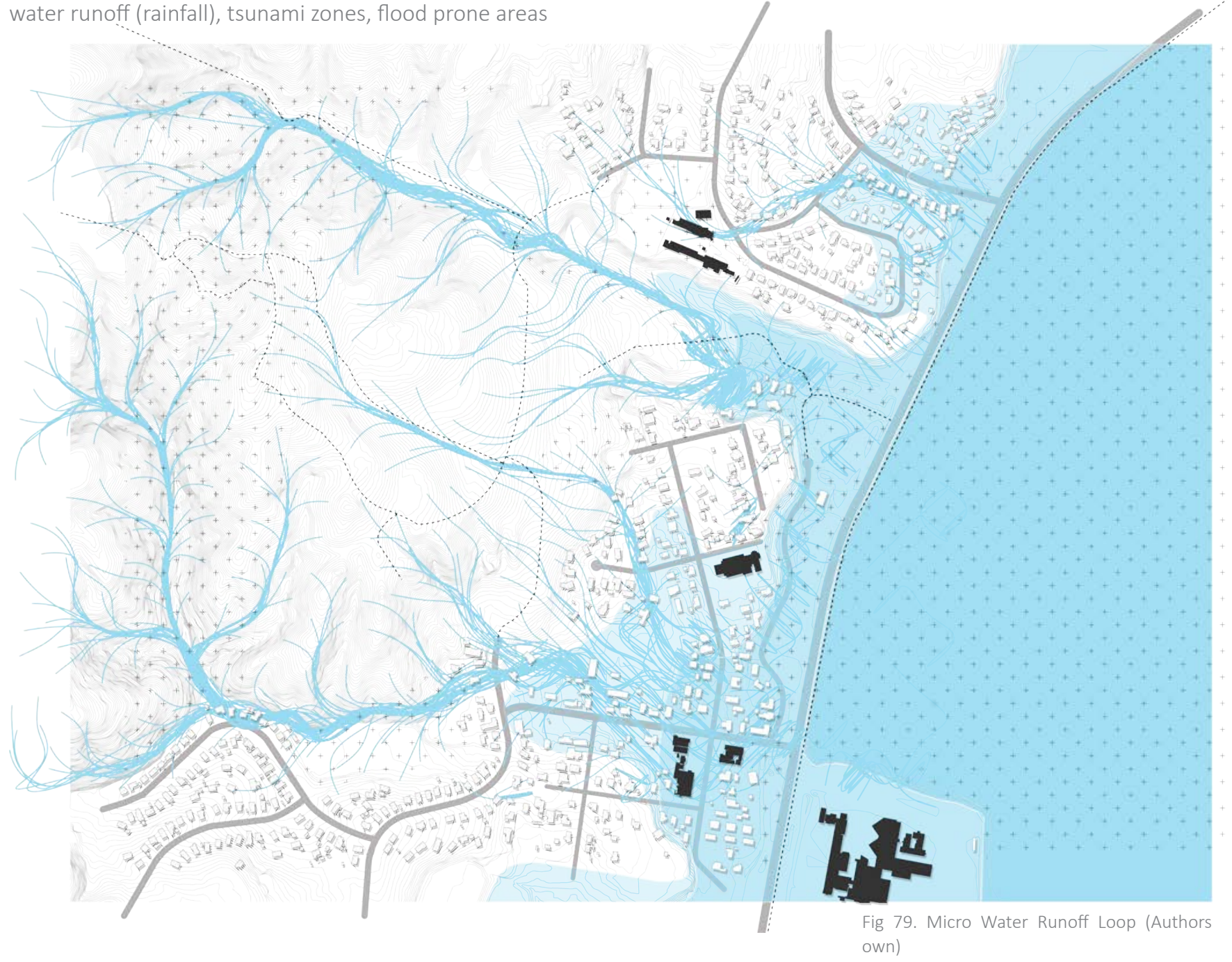




\section{MACRO \\ VEGETATION}

The Porirua environment is a rich podocarp/broadleaf forested landscape residing in complex hilly terrain with a strong coastal influence. Turbulent winds create localised micro climates, making the area generally warm and moist. On higher slopes northern rata and rimu forests cover the hillsides and kowhai and ngaio fringing the dry harbour banks. The heritage trees for this area were predominantly kahikatea and rimu.

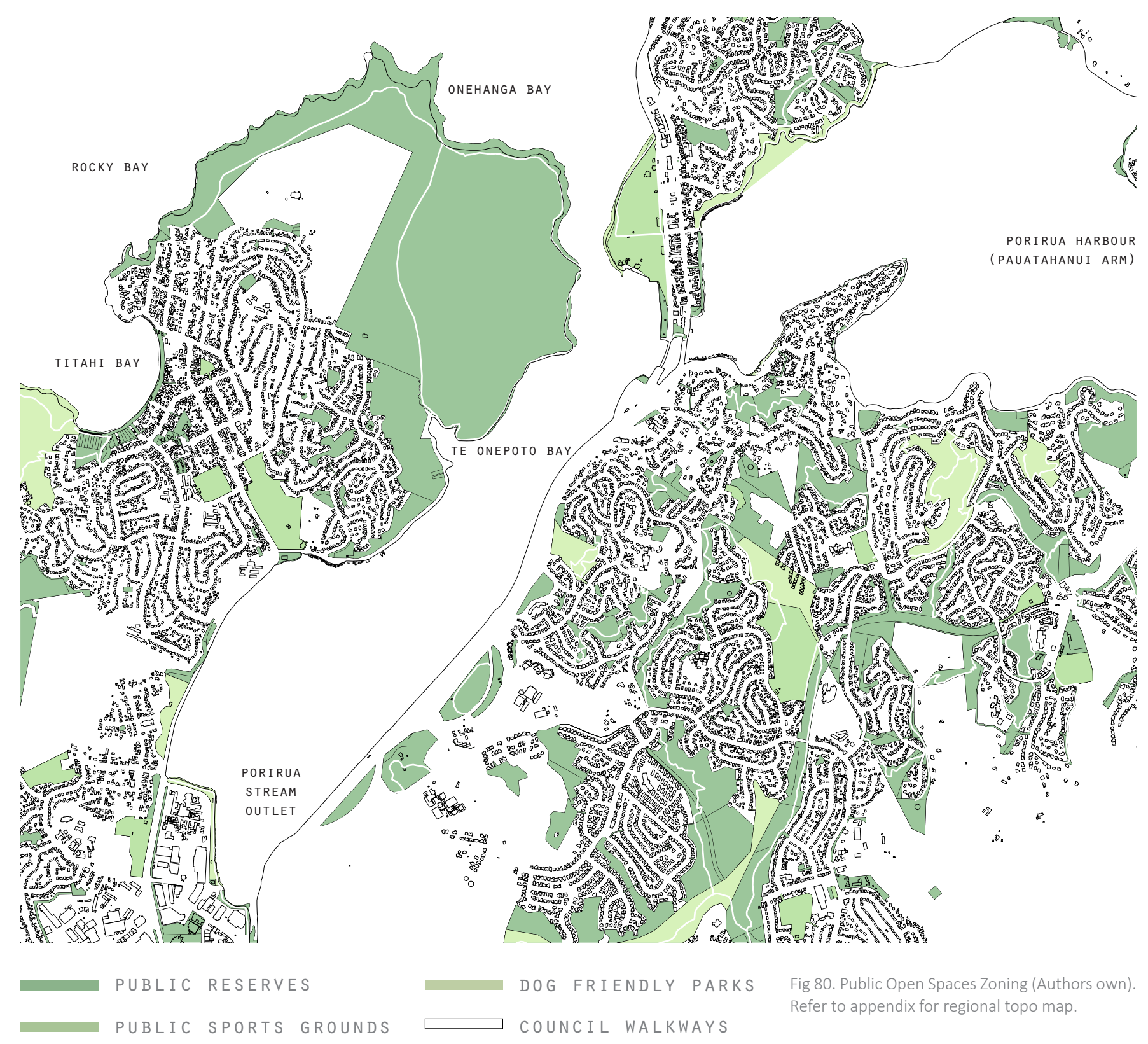




\section{MICRO}

\section{VEGETATION}

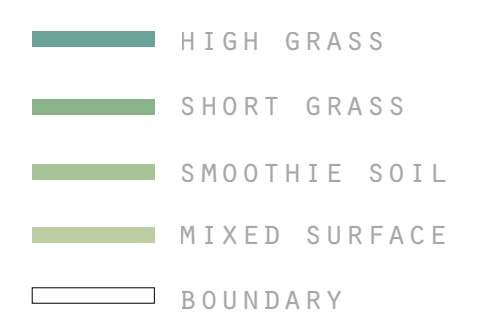

NGATI TOA LANDHOLDINGS

401,180 M2

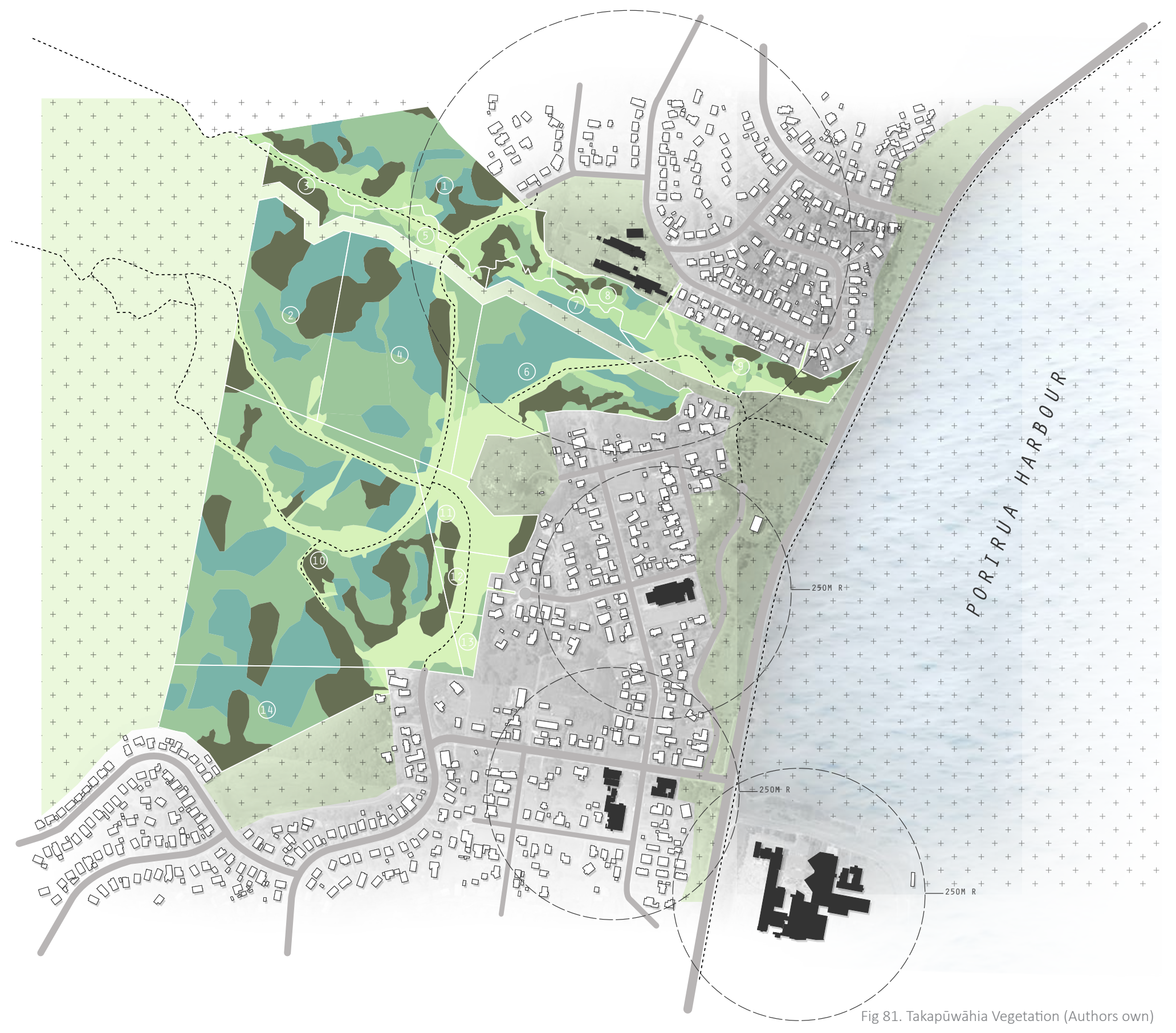




\section{TREE PALETTE}
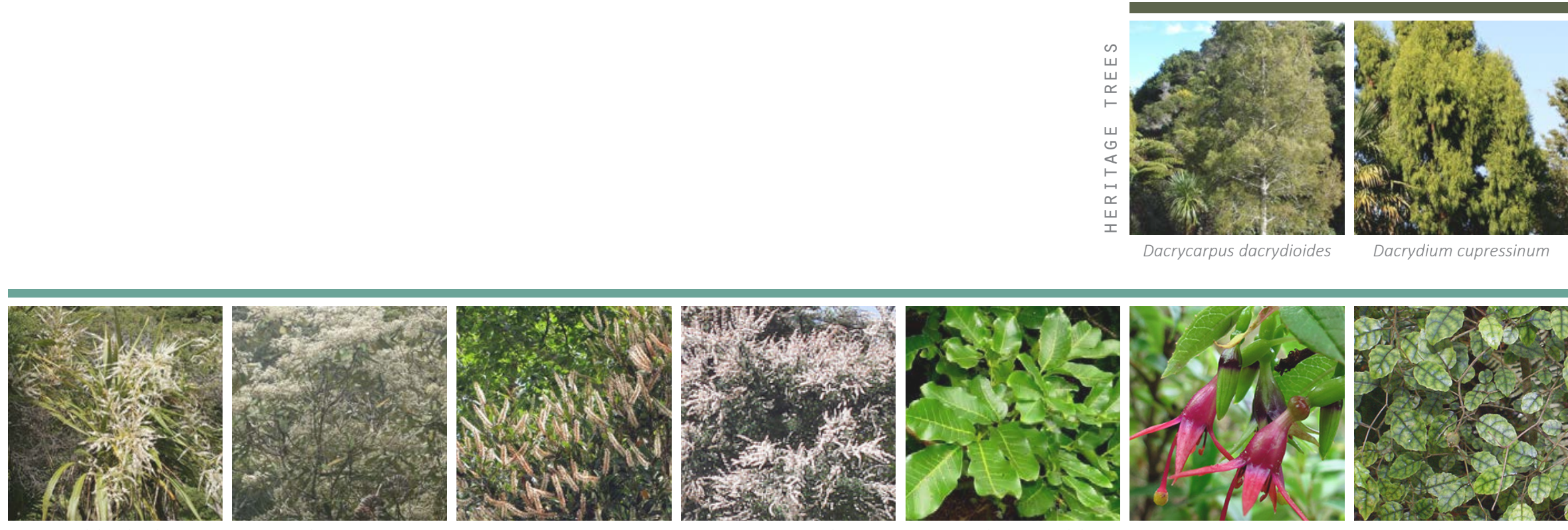

Dacrydium cupressinum

Cordyline banksii

Olearia rani

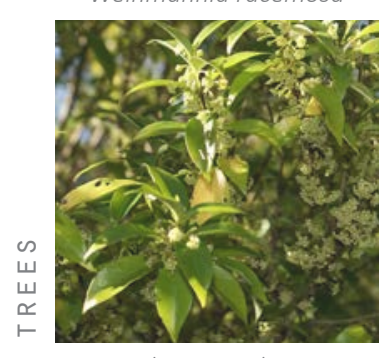

Hedycarya arborea

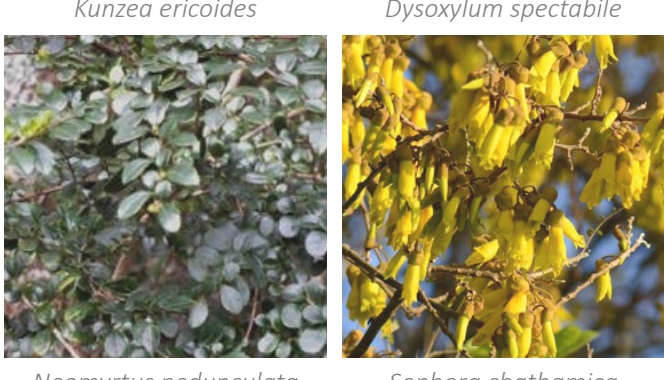

Neomyrtus pedunculata
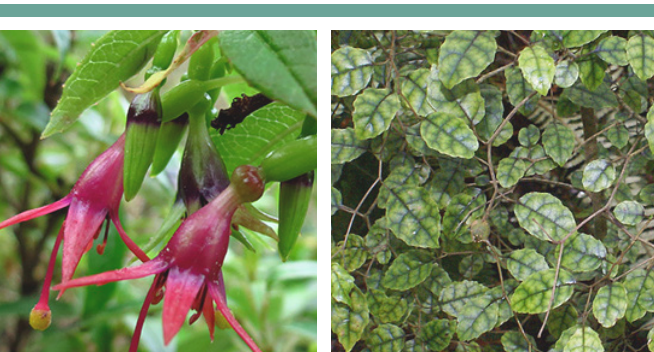

Carpodetus serratus

Fuchsia excorticate

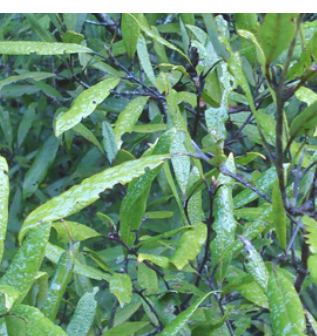

Beilschmiedia tawa

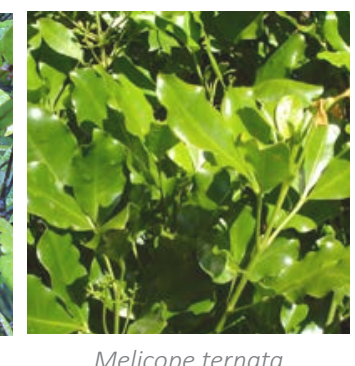




\section{PLANT PALETTE}
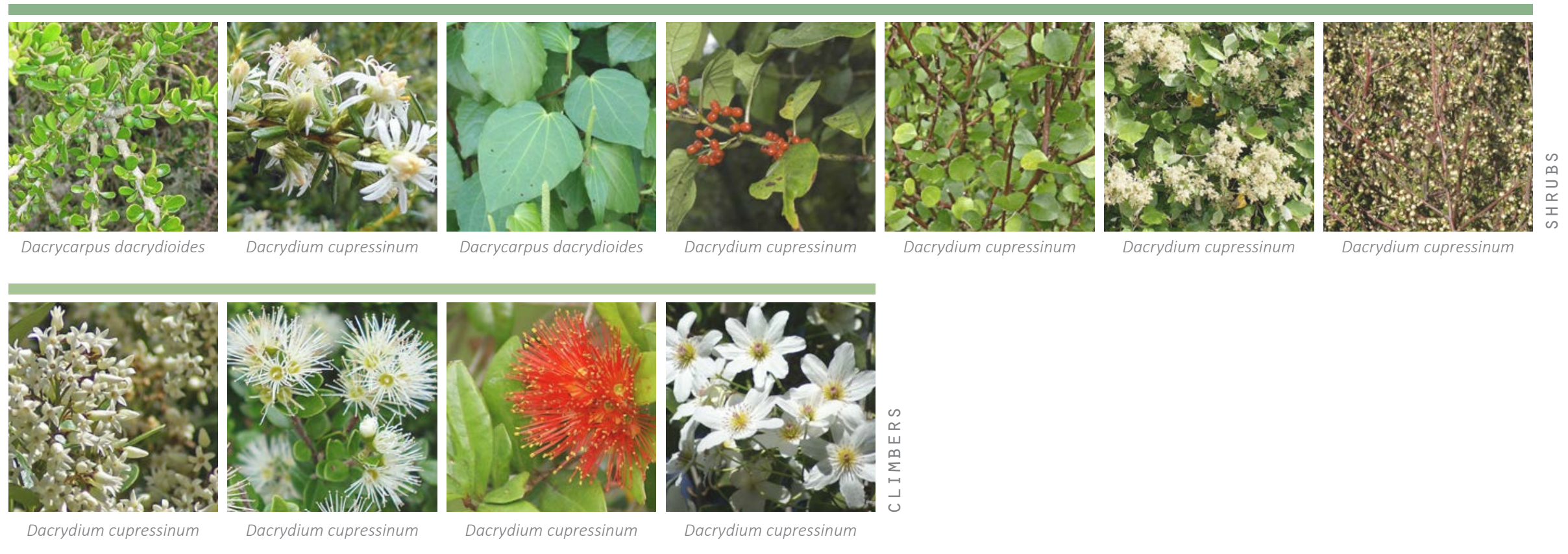

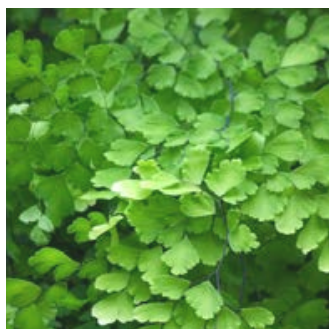

Dacrydium cupressinum

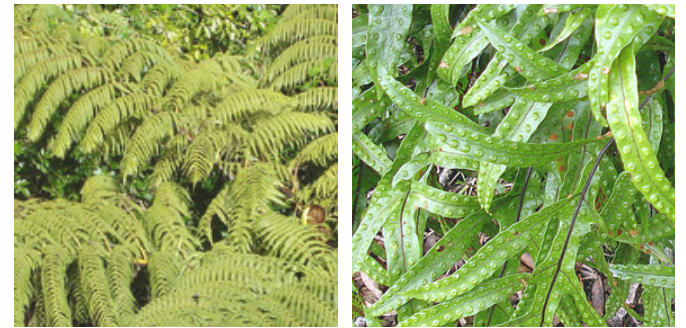

Dacrydium cupressinum

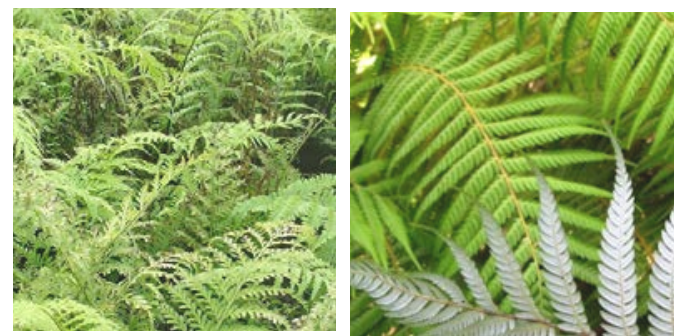

Dacrydium cupressinum

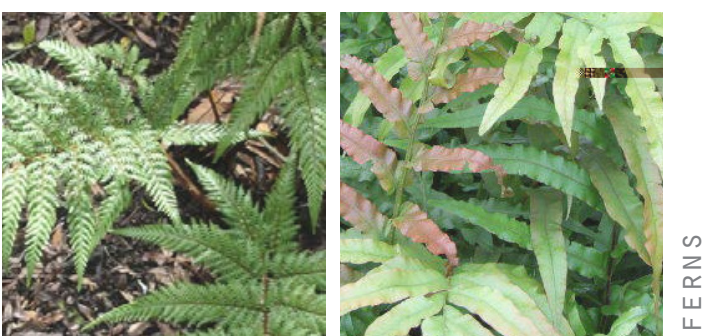

Dacrydium cupressinum

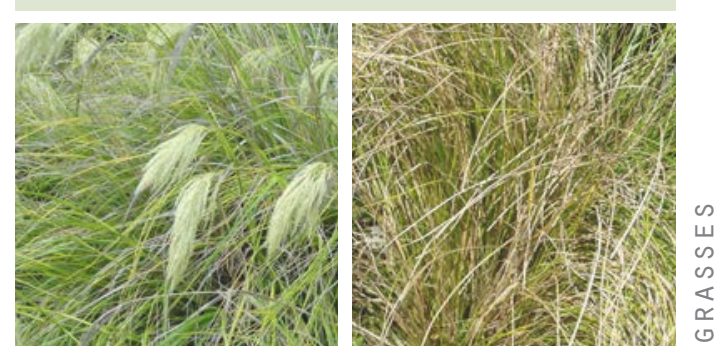

Fig 83. Plant Palette (Authors own) 


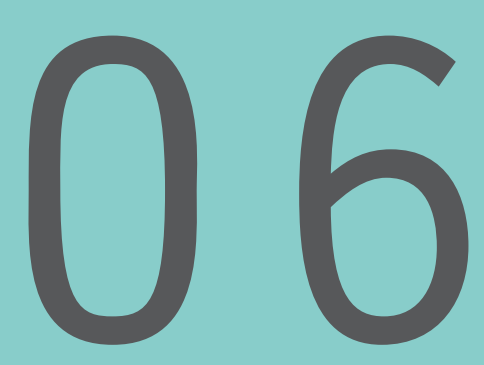

DESIGN

INVESTIGATIONS

This section begins to look at how the developed

method can be used to investigate design solutions

for site with response to cultural values, development

impacts and mitigation. 


\section{DESIGN INVESTIGATIONS}

This design investigation section brings together the research findings accumulated during the entire testing of the digital landscape system. The information gathered has been organized through a series of design iterations in order to display the design evolution from conceptual, simulated, and integration of cultural values. Two frameworks and four design concepts for site conditions were developed where data simulations have occurred and been implemented to address and help mitigate some of the site issues specified By exploring and developing the methodology, design ideas have emerged as options start addressing certain areas of site.
The presented conceptual designs address the site specific issues surrounding flooding- wetlands, sea level rise- coastal stabilisation, and lack of public connections- bush and stream walkways. Each site condition was able to test the fundamental components of the digital landscape system through the input of data. Through these iterations the research was able to gain a broad understanding of spaces and how they react whilst enhancing the sense of interactive spatial experience through the building of a realistic landscape environments. These designed environments were used to measure the fluidity of immersion through reflection and critique, and could prompt tentative experiments to initiate discussion surrounding the advancements of land management. The concluding concepts encompass elements of each of the systems components and proves how this approach could be used as a new interwoven workflow for designers and Iwi members within the field of landscape architecture.

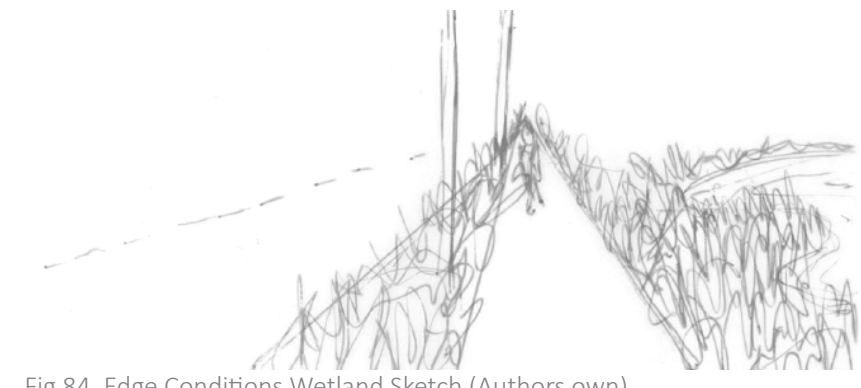

Fig 84. Edge Conditions Wetland Sketch (Authors own)

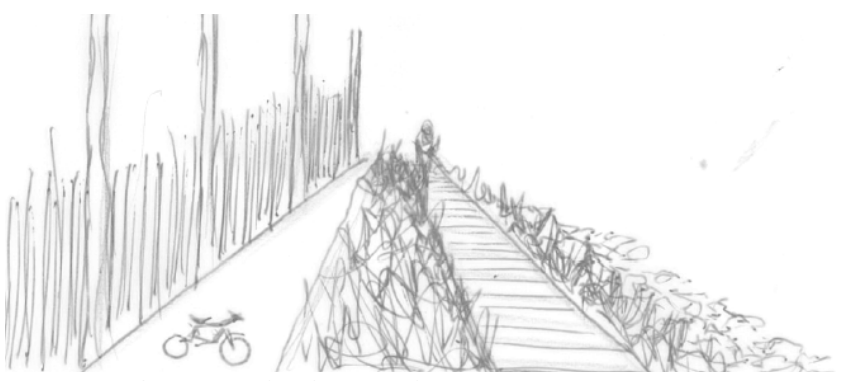

Fig 85. Significant Sites (Authors own) 


\section{SIGNIFICANT SITES}

Four sites within Takapūwāhia have been identified by Ngāti Toa Rangatira as key locations to build upon within the research. The purpose of referencing these significant sites is to re-invent the approach toward the hybridisation of conservation and occupational spaces that are of importance to the local Iwi. These locations should consider the role of the wider designed ecological links and recreational trails as a frameworks for enabling design-led concepts and experimentations which engage with traditional aims and goals to ensure these sites are sustained for future generations. The purpose of interconnecting these sites through a design was to create a more efficient use of the sites assets, giving locals a reason to reflect and use them on a day to day basis with full integration as a means of access.

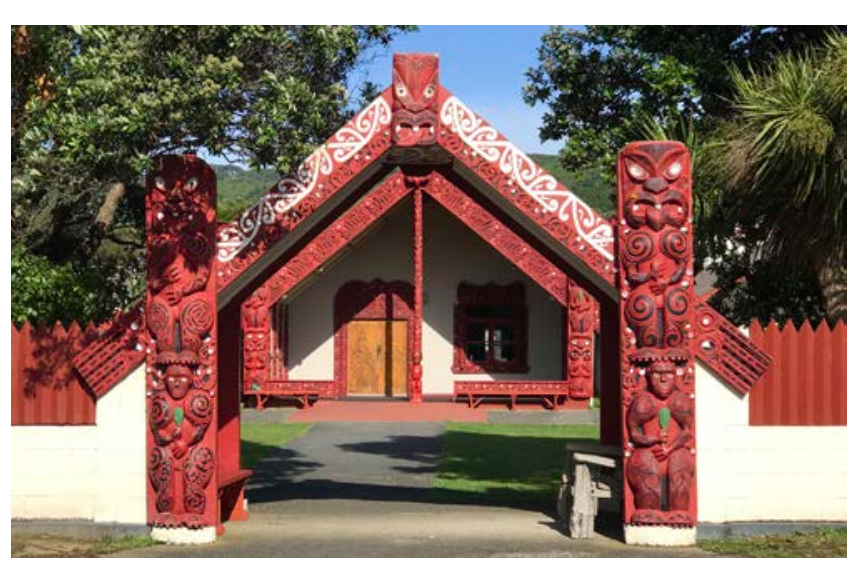

TAKAPUWAHIA MARAE

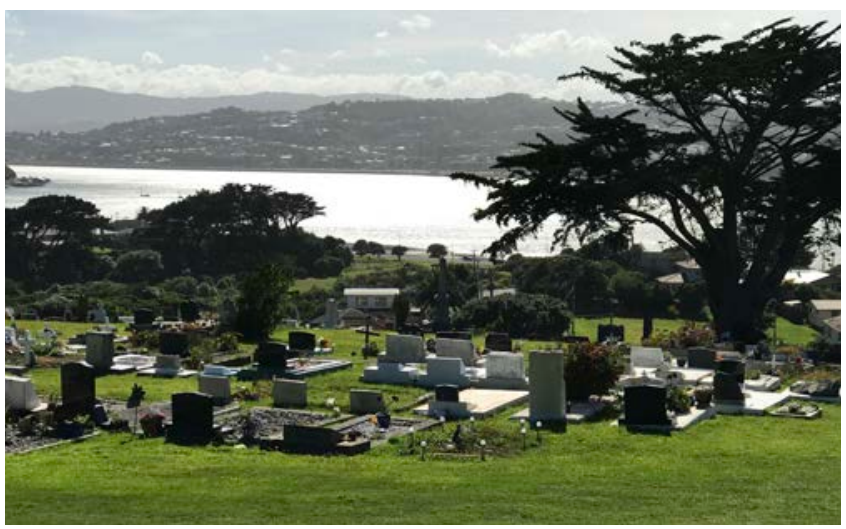

TAKAPUWAHIA CEMETERY Fig 86. Significant Sites (Authors own)

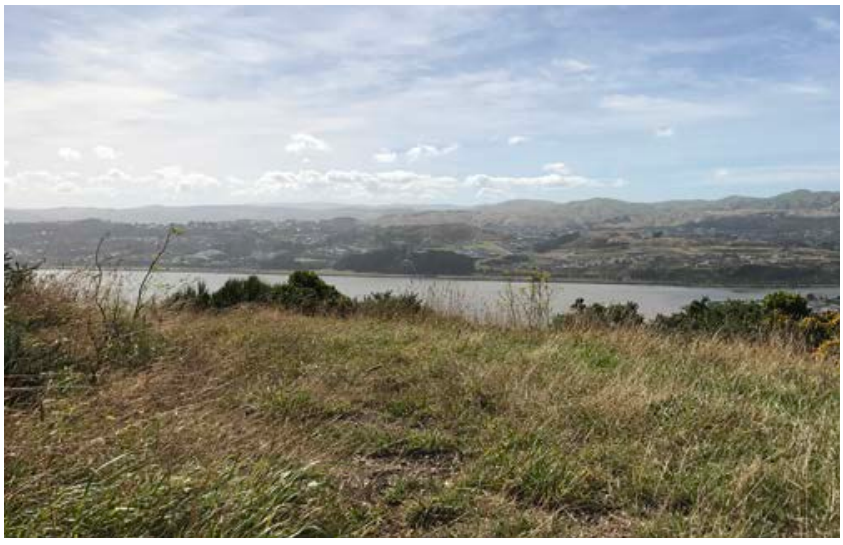

LAND HOLDING HIGH POINT

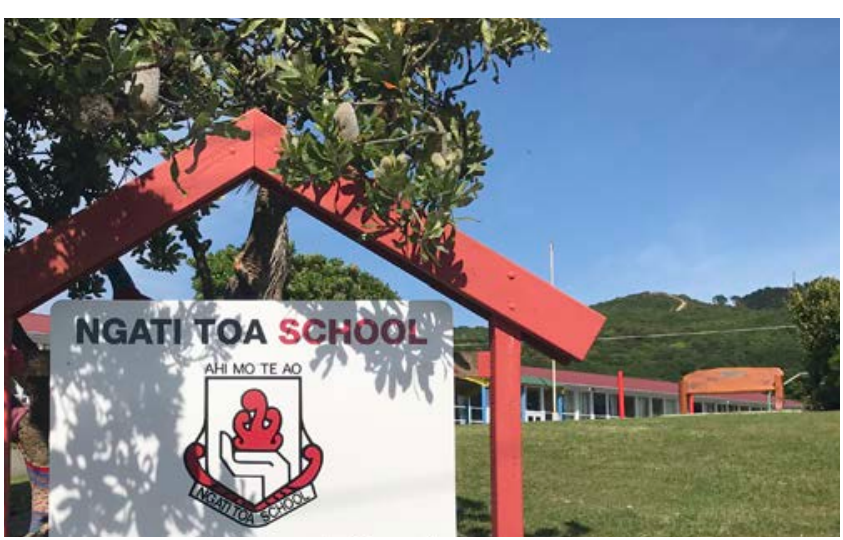

NGATI TOA SCHOOL 

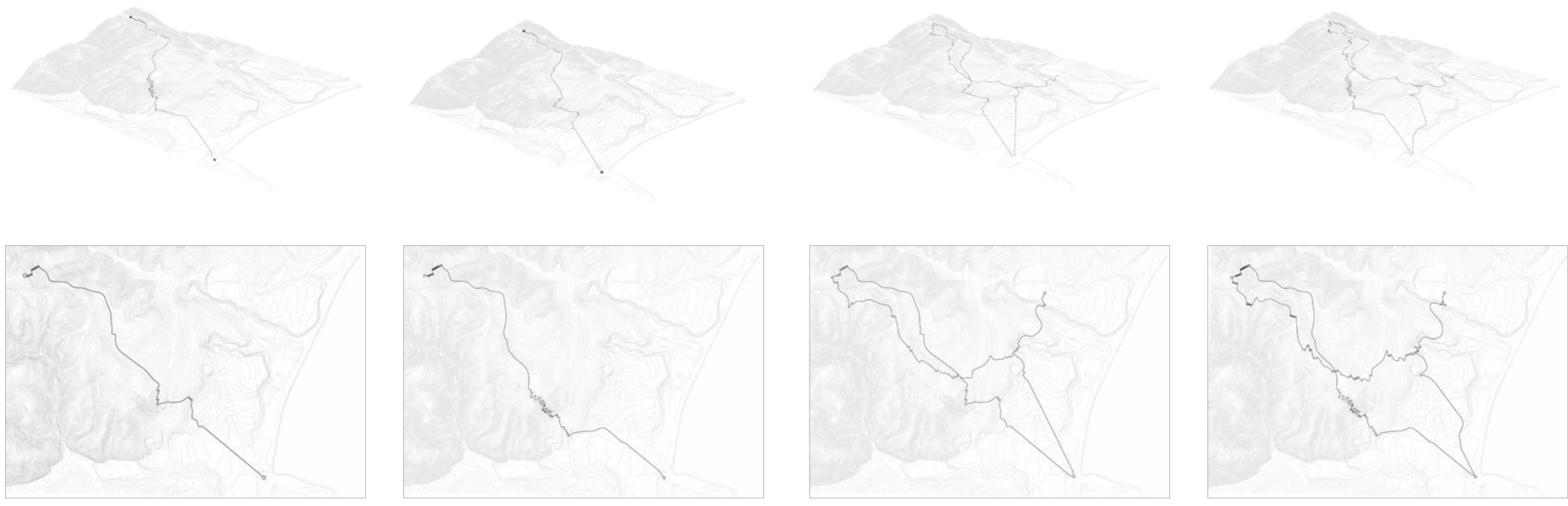

Above Fig 87. Trails to Significant Sites (Authors own). This site perspective illustrates the trail paths from around site. 

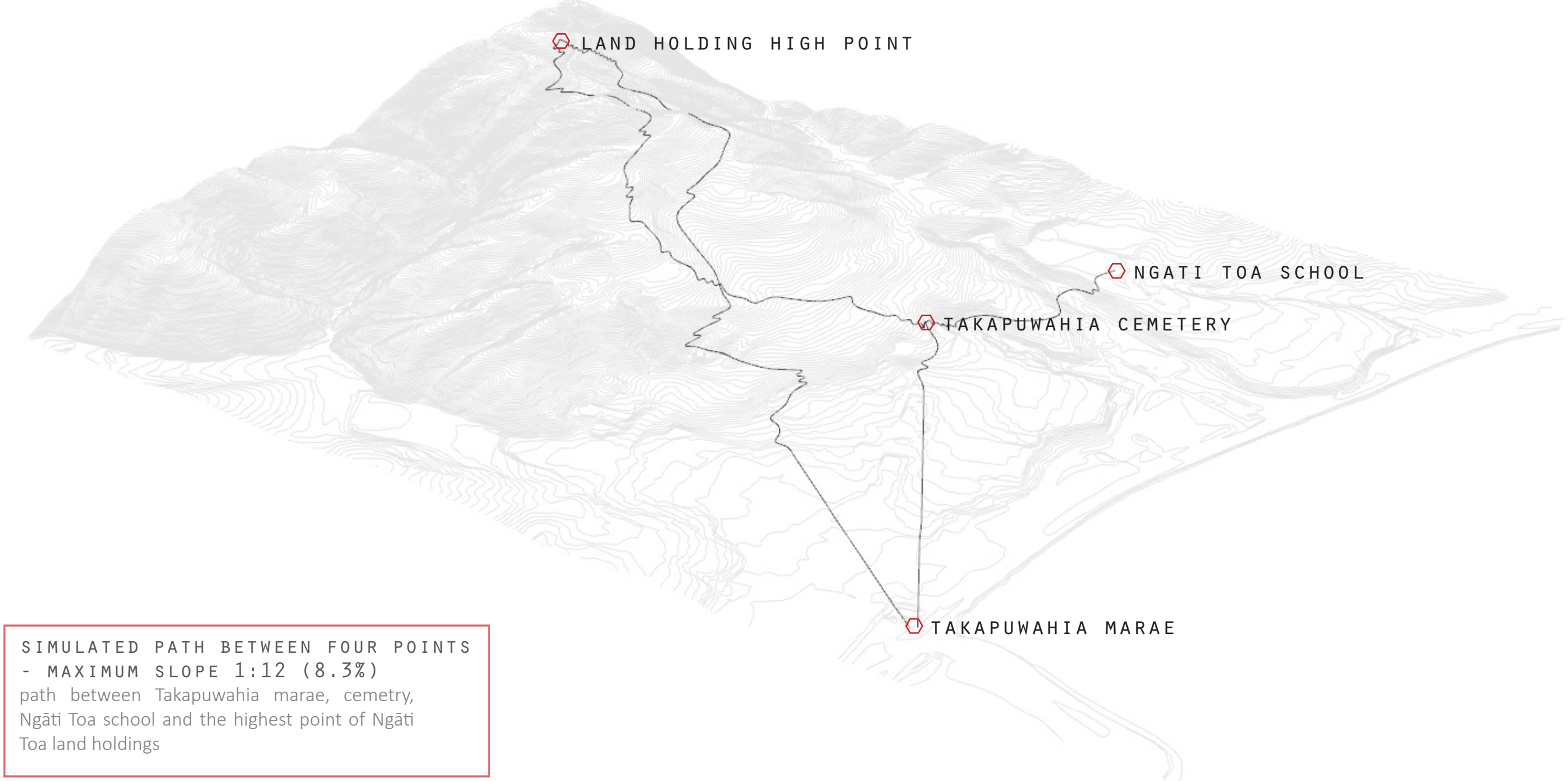

NOT SUITED 

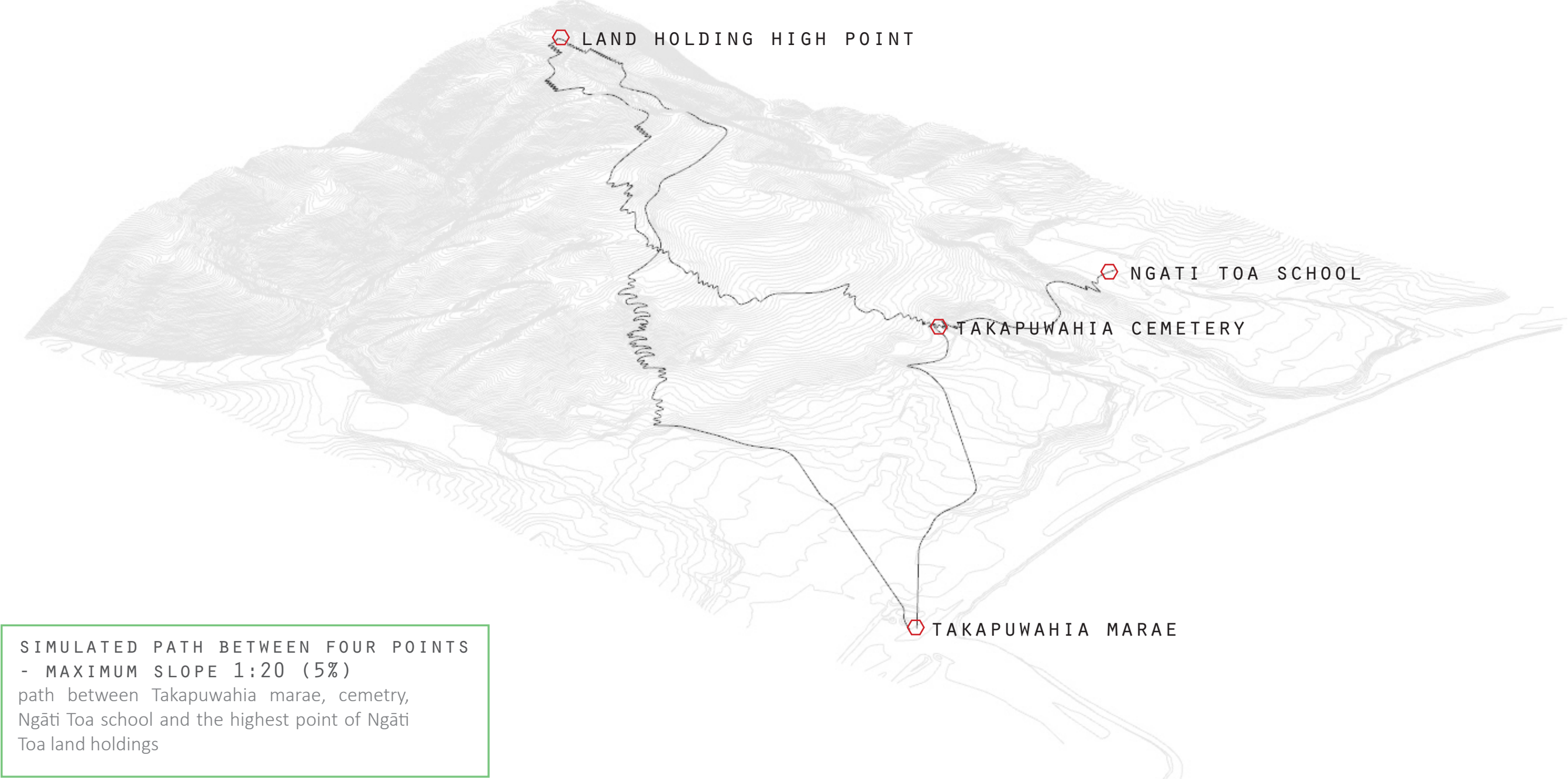

PREFERRED OPTION 


\section{CONDITION ZONING}

It is important to make note of these definitive 'features' within each environment in order to instigate interest from local iwi and drive occupational outcomes and solutions. Programmatic options that align with ecology, sustainable use, and management can then be determined and applied within a more intimate context through the use of this methodology.

Through this process the research was able to identify and define four key environments of which design conditions could be applied and built upon. In terms of design the research was able to generate options deemed appropriate for recreational intervention and then input specific land use around this as a frameworks to work in conjunction with an overall environmental and amenity benefit to the local community.

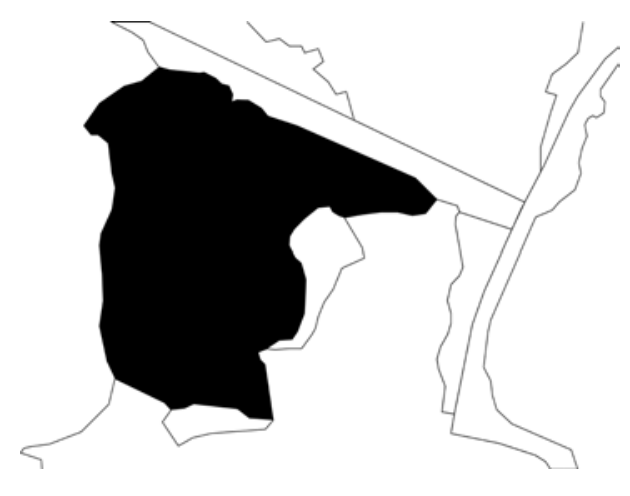

\section{B U S H}

Regenerative Bush

Remnant Planting

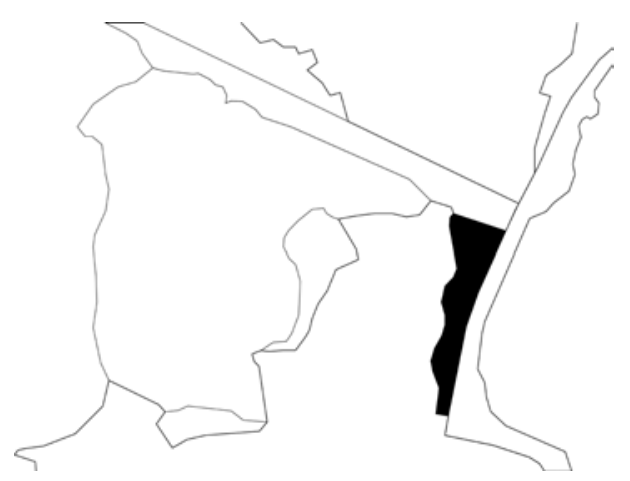

WETLAND

Flood Control

Botanical Nursery

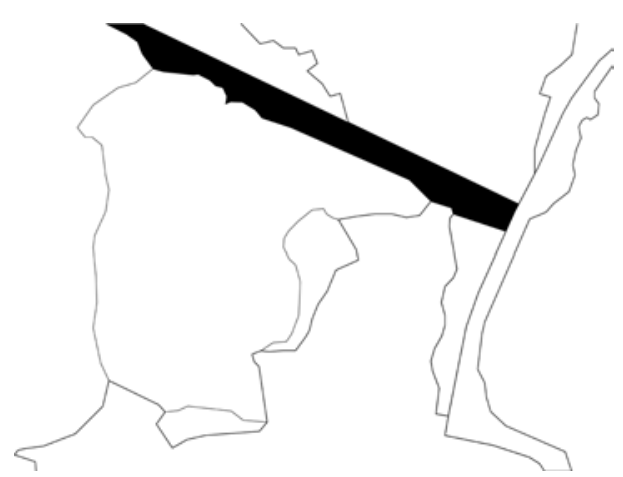

\section{S TREAM}

Bank Stabilisation

Water Storage

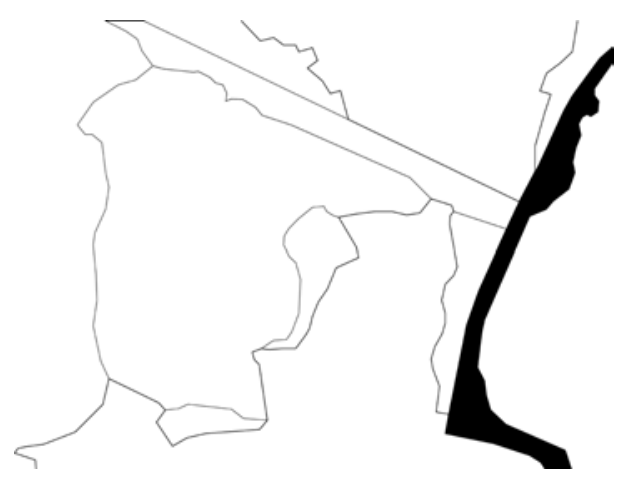

COASTAL

Coastal Protection

Wind/Erosion

Fig 90. Condition Zoning (Authors own) 


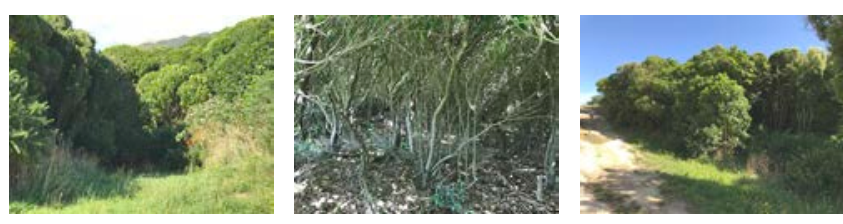

EXISTING BUSH

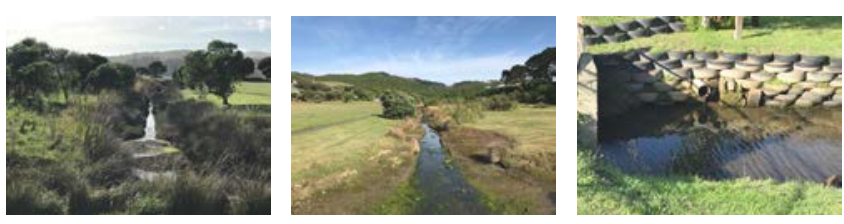

EXISTING STREAM

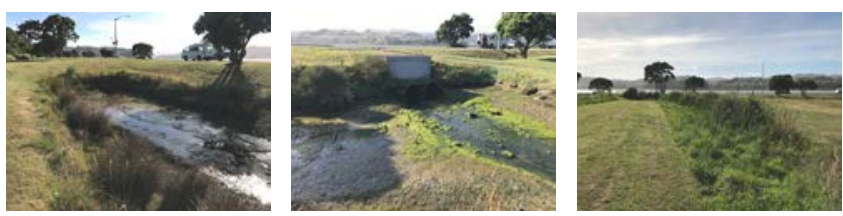

EXIS ITNG WETLANDS

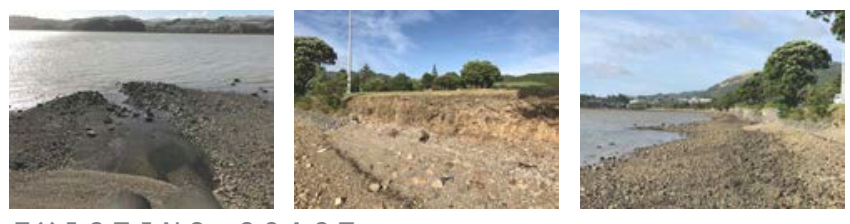

EXISTING COAST

Above Fig 91. Existing Zoning (Authors own). This

site perspective illustrates the elevation from

coast to ridge.

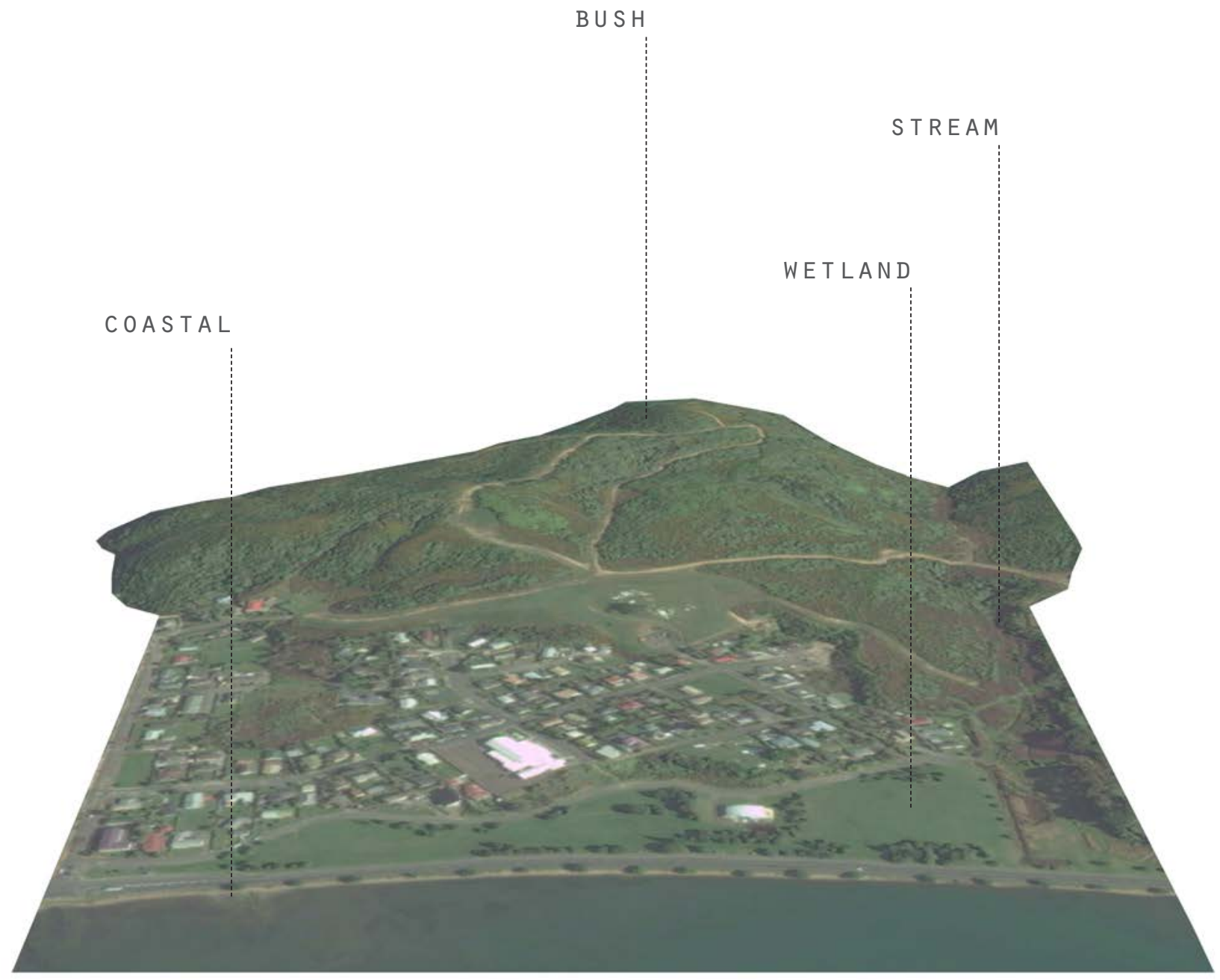




\section{RECREATION STRATEGY}

WALKWAYS

MARKER SITES

The amount of restoration needed to reinstate the natura ecologies which once occupied this piece of land was essential to the research to provide a baseline to build upon and help to identify areas for other potential interventions The recreation frameworks is used as a connector of significant spaces and is designed to provide a safe and navigable pathway for users to venture through the site. The path is a 1:20 gradient between all four sites and is positioned to pass through four different conditions on site. The main purpose behind this crossover was to ensure that users would experience all the different elements offered.

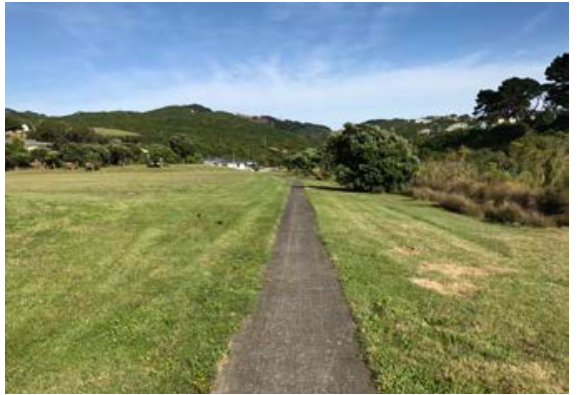

Fig 92. Exisitng Walkways (Authors own)

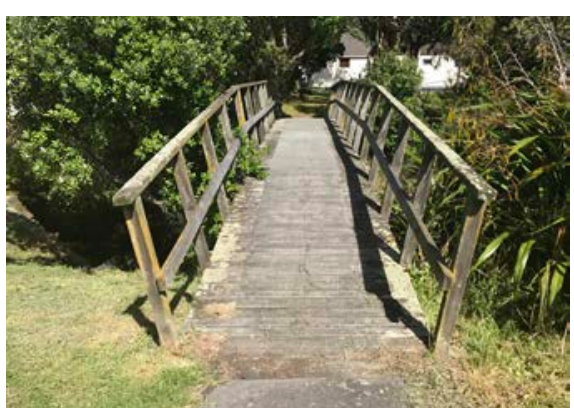

Fig 93. Exisitng Footbridge (Authors own)

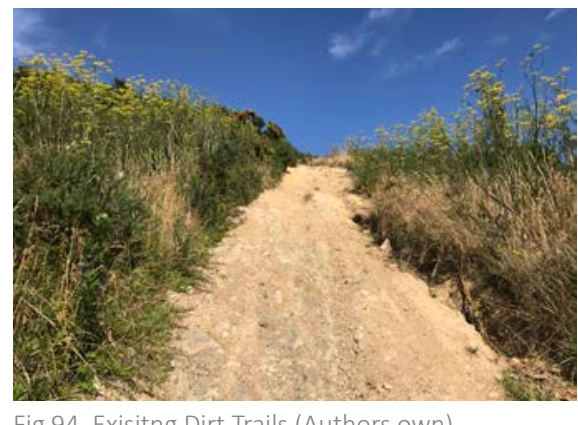

Fig 94. Exisitng Dirt Trails (Authors own)

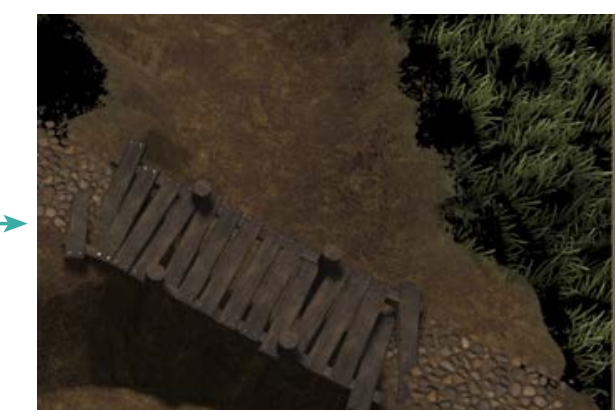

Fig 95. Landscape Material not Height Blended (Detocroix, 2014)

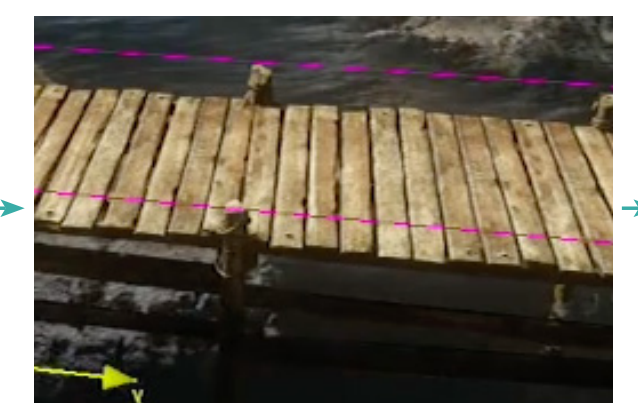

Fig 96. Footbridge Texturing and

Reflection (Detocroix, 2014)

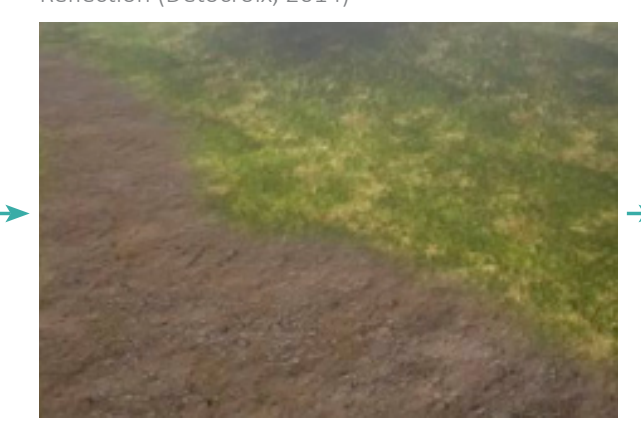

Fig 97. Ue4 Dirt Trail 1:20 Gradient (Vea Games, 2015)

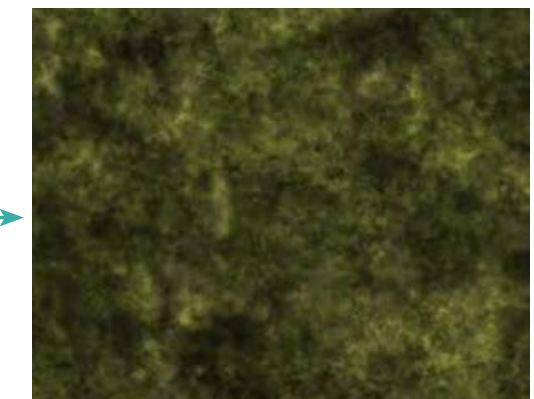

Fig 98. Ue4 Grass Texture (Authors own)

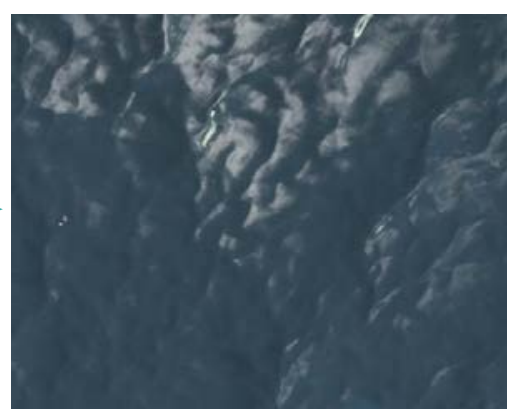

Fig 99. Ue4 Water Texture (Authors own)

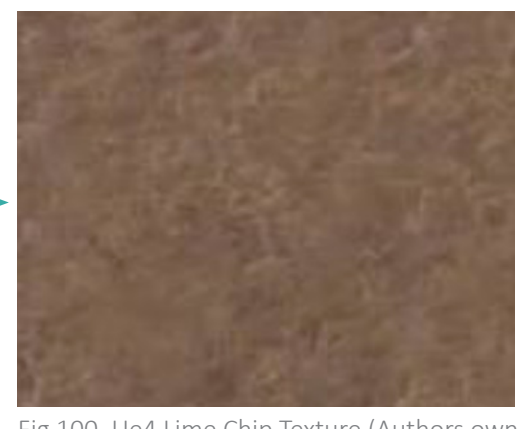

Fig 100. Ue4 Lime Chip Texture (Authors own)

TRANSLATING RECREATION ELEMENTS TO 3D MODELS 


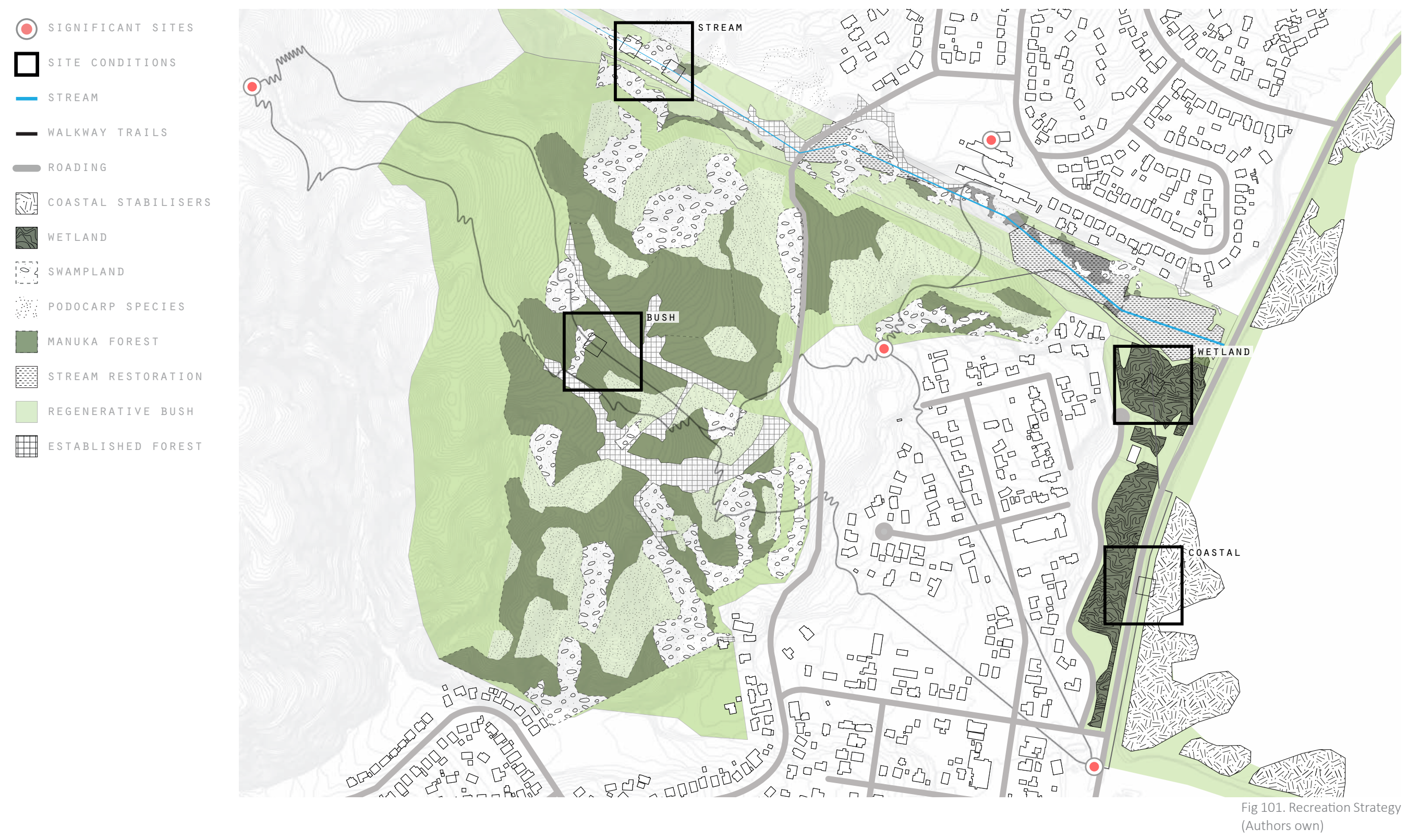




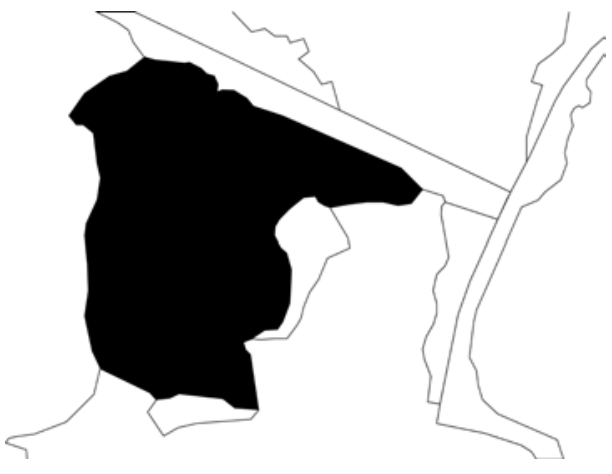

TYPICAL CONDITION $\mathrm{BUSH}$

Regenerative Bush Remnant Planting

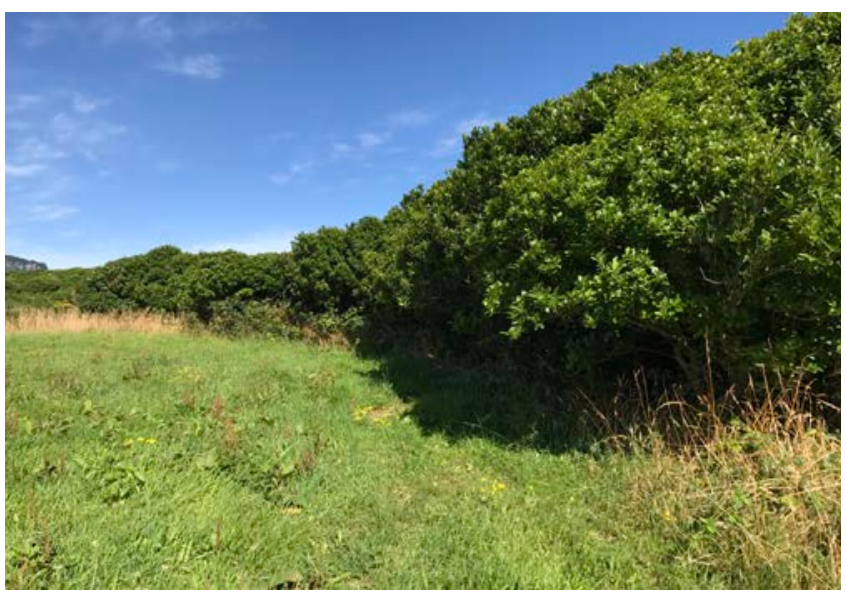

Fig 102. Existing Bush Edge Condition (Authors Own)

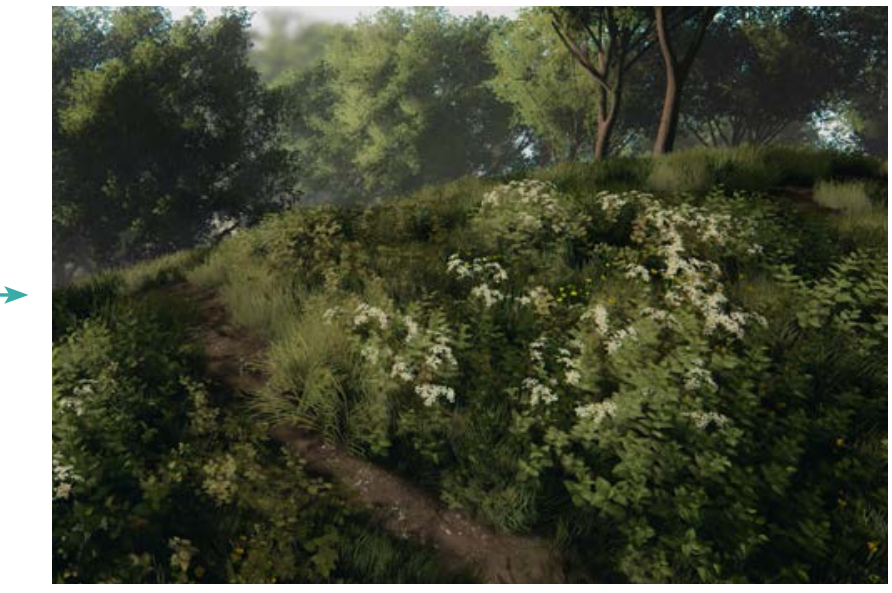

Fig 103. Foliage Environment (Patron, 2014)

PROPOSED SITE CONDITIONS IN UE4

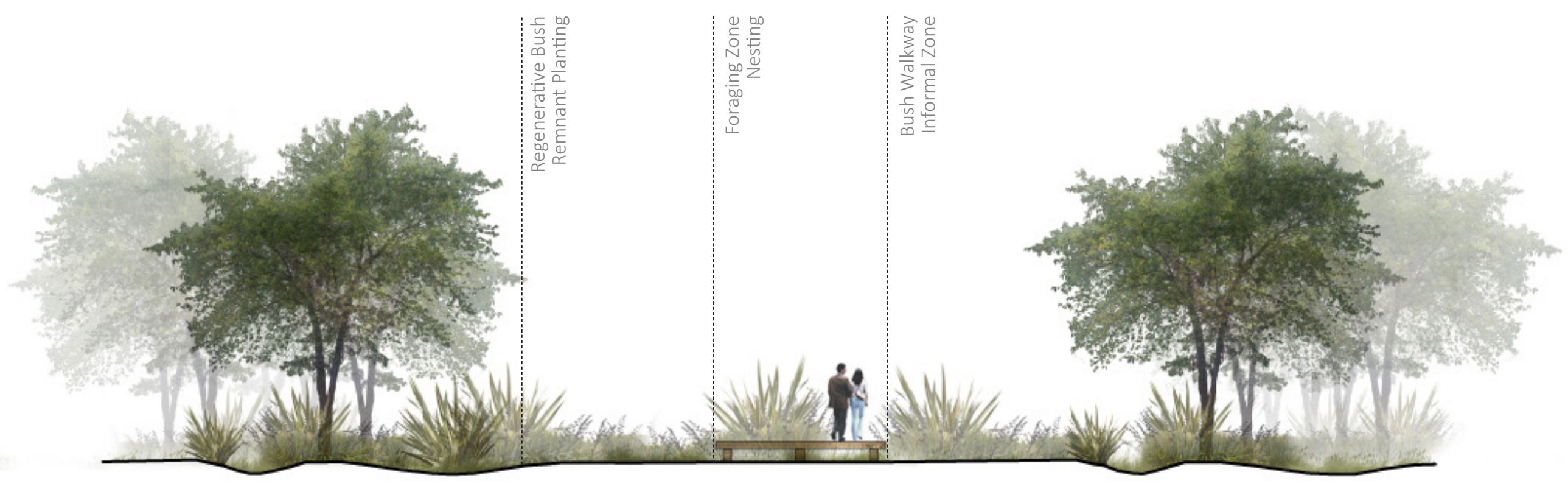

Fig 104. Bush Section 1:200 (Authors own) 


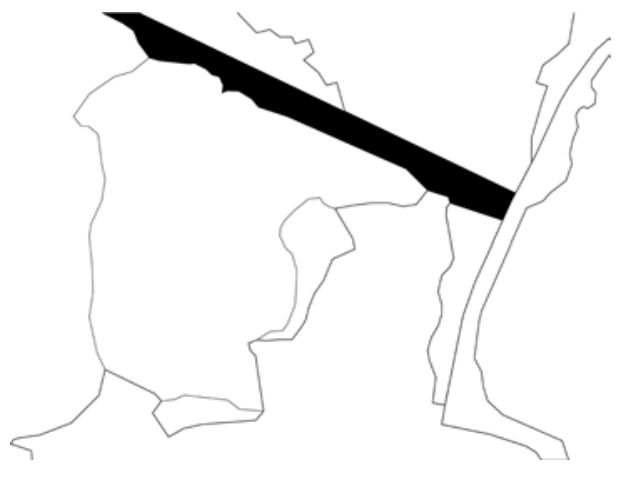

TYPICAL CONDITION STREAM

Bank Stabilisation

Water Storage

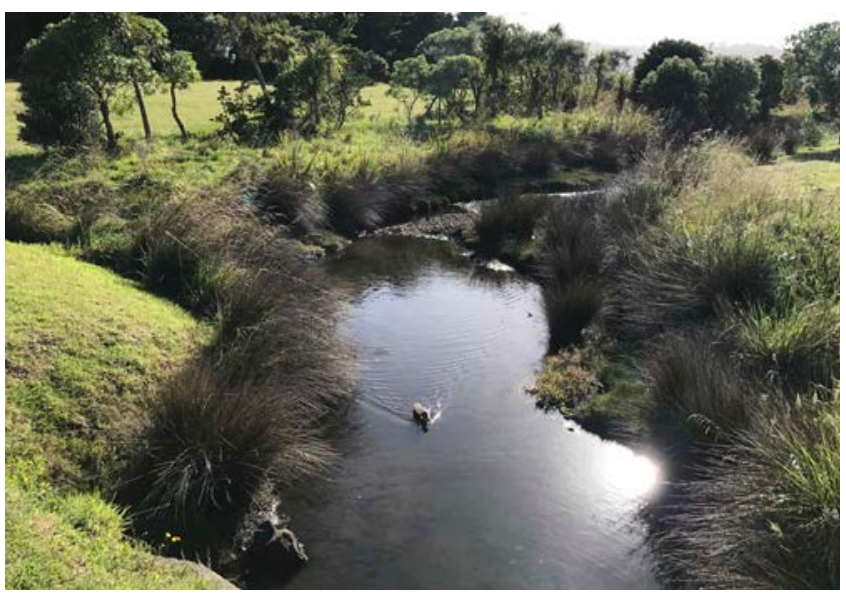

Fig 105. Existing Stream Condition (Authors own)

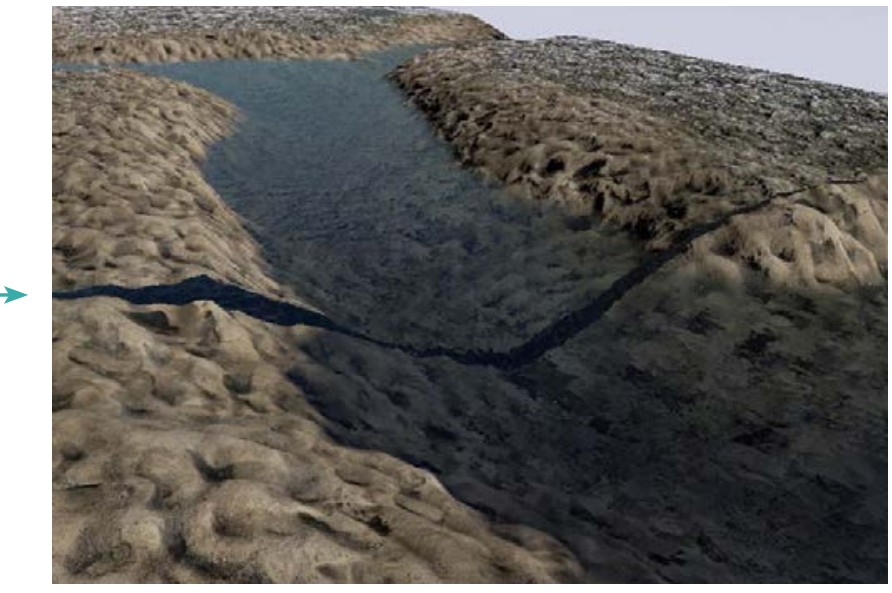

Fig 106. Difference in Landscape Height (Murray, 2015)

PROPOSED SITE CONDITIONS IN UE4

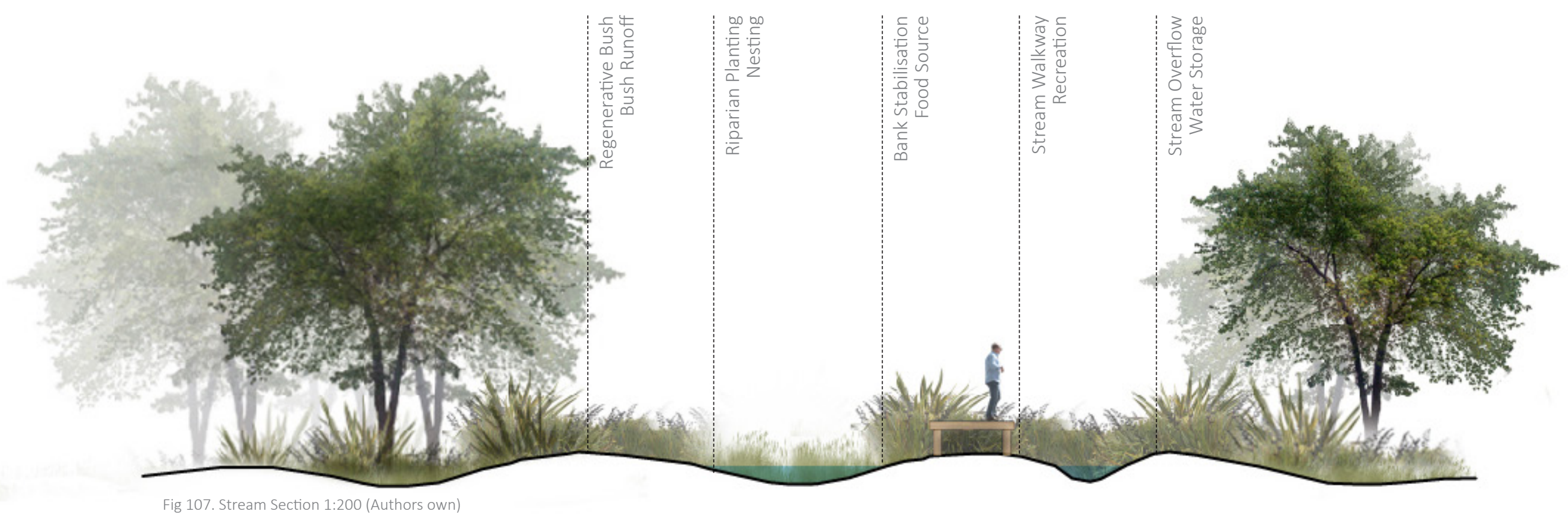




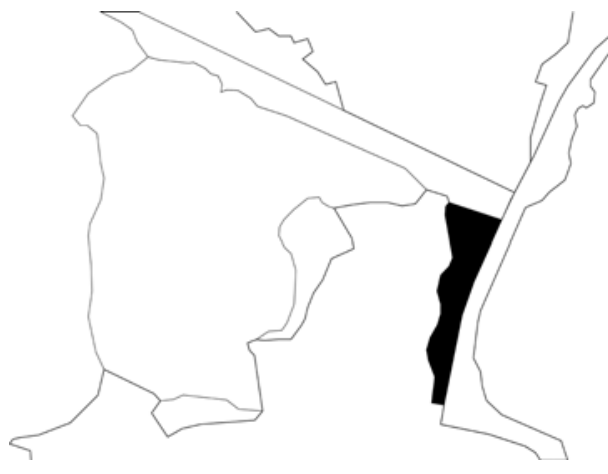

TYPICAL CONDITION

WETLAND

Flood Control

Botanical Nursery

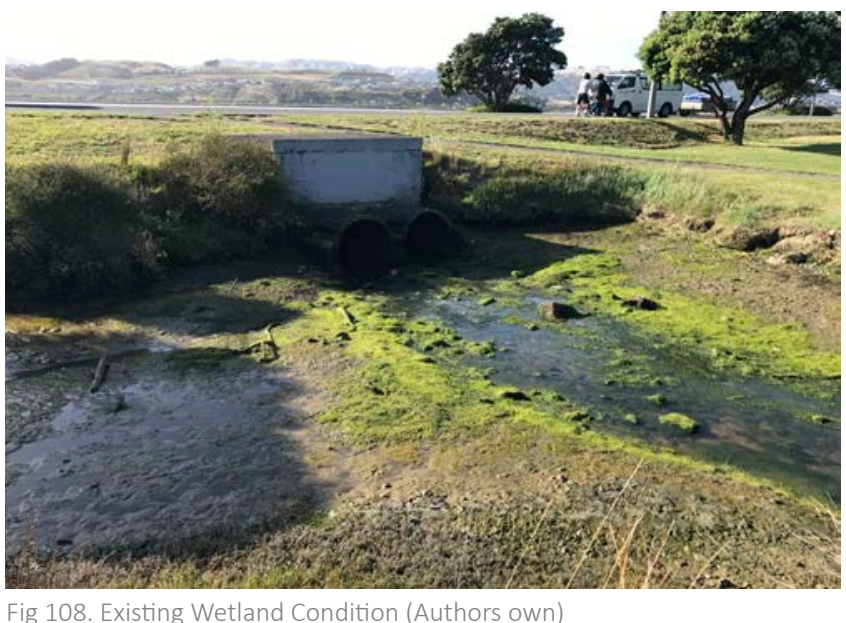

PROPOSED SITE CONDITIONS IN UE4

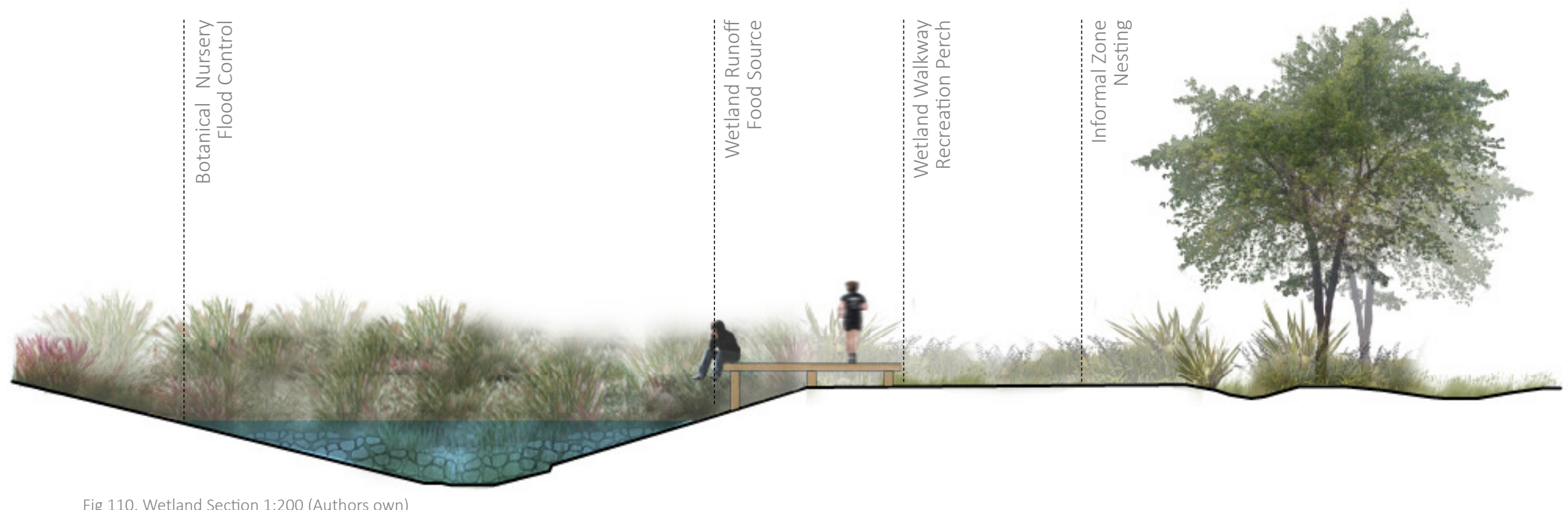

Fig 110. Wetland Section 1:200 (Authors own) 


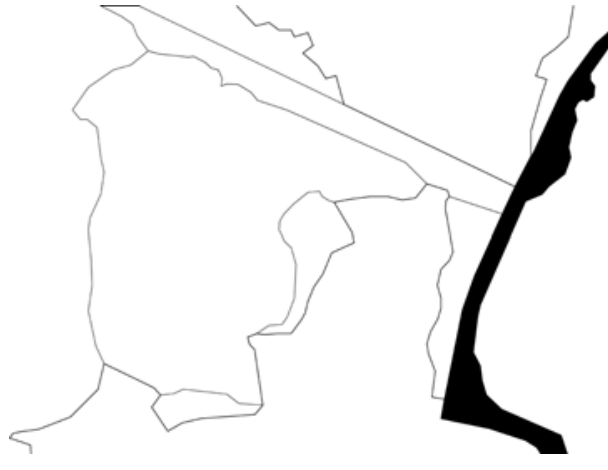

TYPICAL CONDITION COASTAL

Coastal Protection

Wind/Erosion

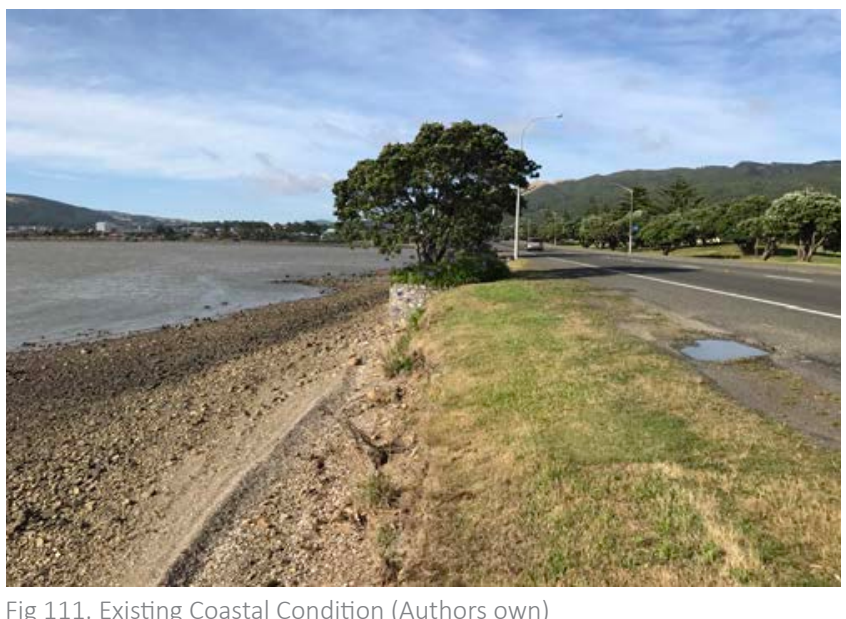

Fig 111. Existing Coastal Condition (Authors own)

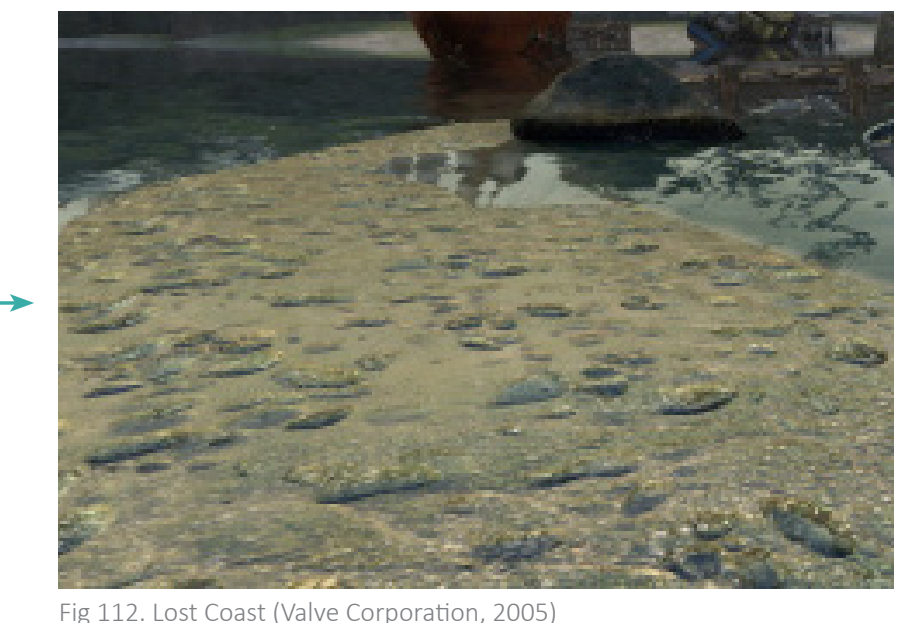

PROPOSED SITE CONDITIONS IN UE4

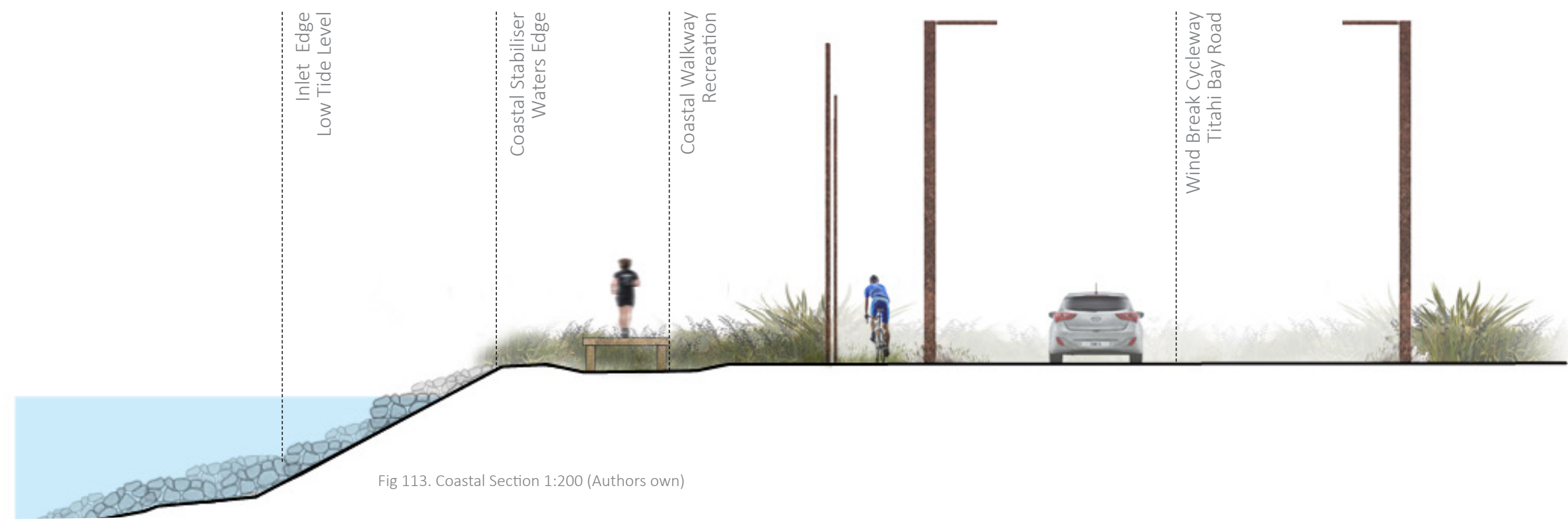




\section{INFRASTRUCTURE STRATEGY}

I W I HOUSING

ROADING NETWORK

Areas with potential for Iwi development were explored such as housing locations. This type of development was outlined by Ngāti Toa Rangatira as a high priority strategy for economic gain given the current Wellington housing market. This design was made as a basic frameworks for the Iw based off some of the simulations (water runoff and solar analysis) run on various digital platforms. The research was able to determine what proportion of the site was needed for restoration effects and the balance available for future development. Attention is drawn to the road transitions that run parallel to the urban development and was tested in the 3D environment ensuring these crossovers between spaces were well considered.

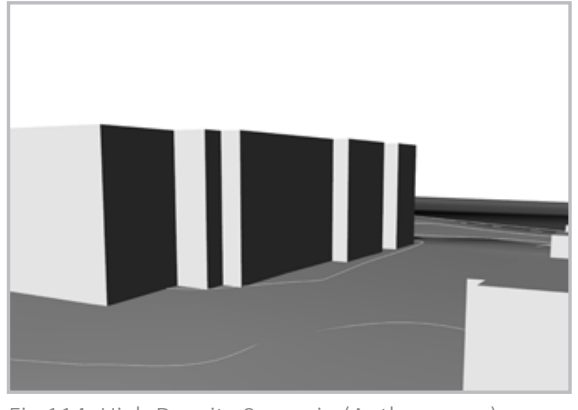

Fig 114. High Density Scenario (Authors own)

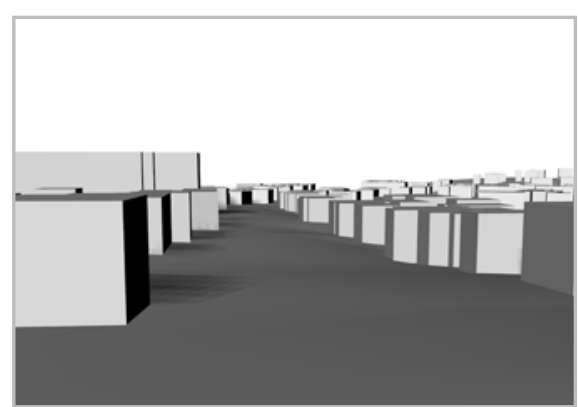

Fig 115. Medium Density Scenario (Authors own)

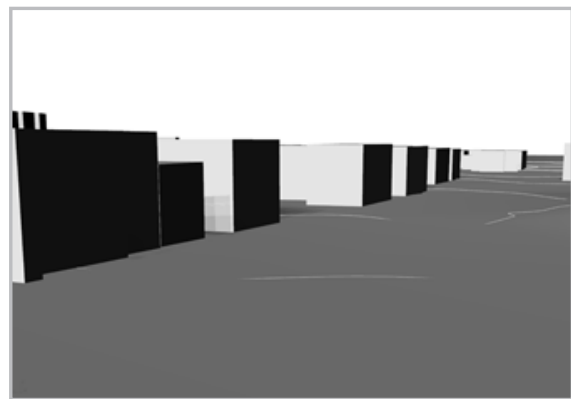

Fig 116. Low Density Scenario (Authors own)

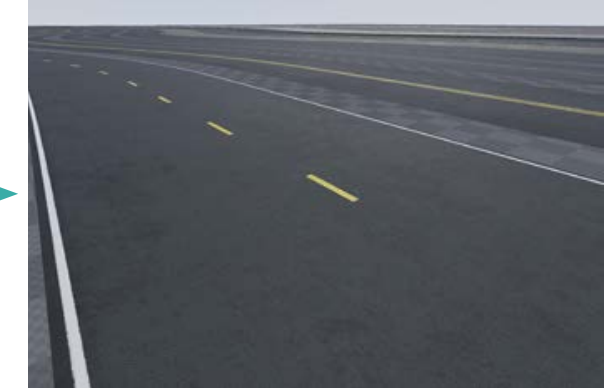

Fig 117. Ue4 Main Roads (Authors own)
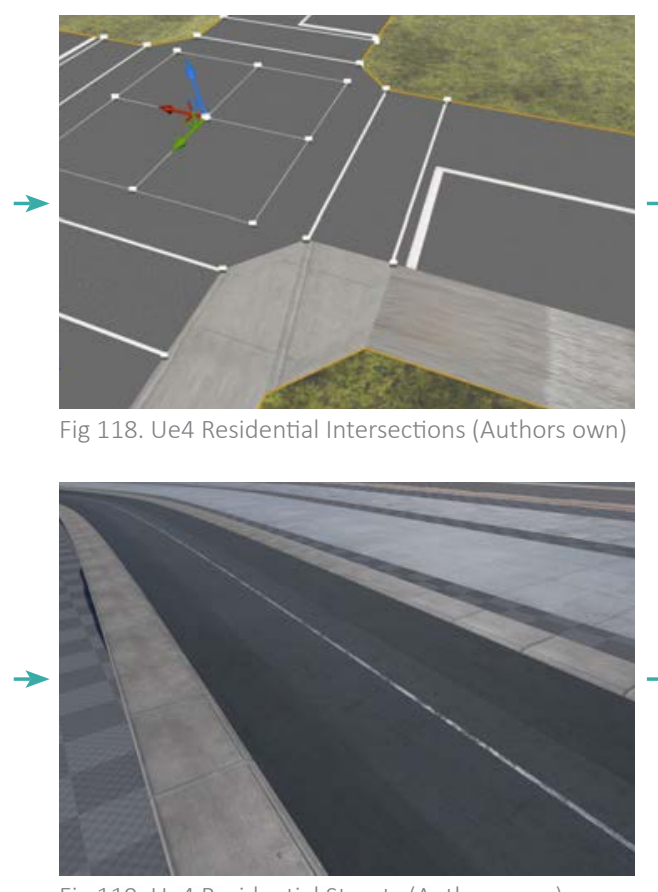

ig 119. Ue4 Residential Streets (Authors own)

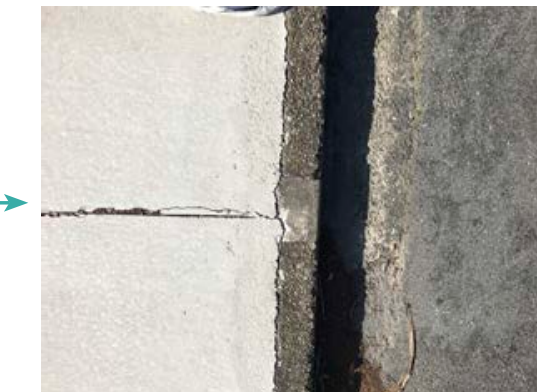

Fig 120. ReMake Concrete Paving (Authors own)
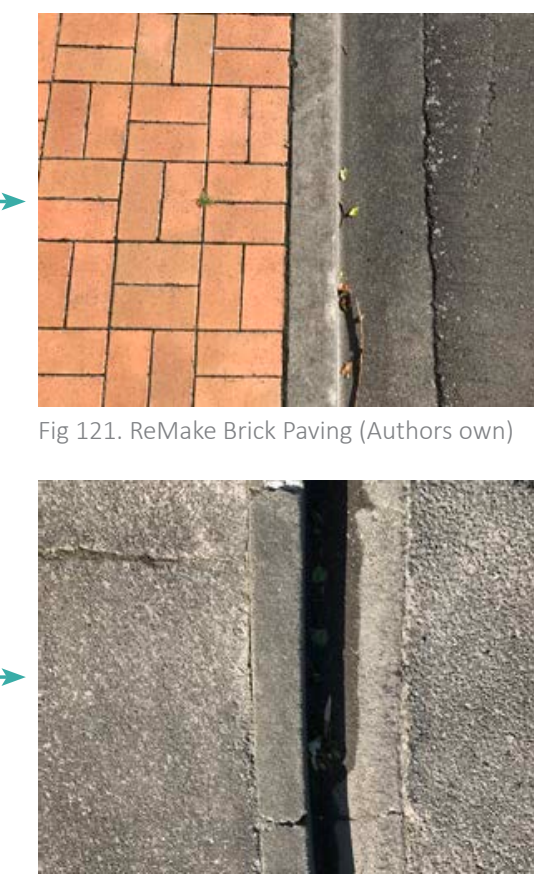

Fig 122. ReMake Aggregate Paving (Authors own)

TRANSLATING RECREATION ELEMENTS TO 3D MODELS 

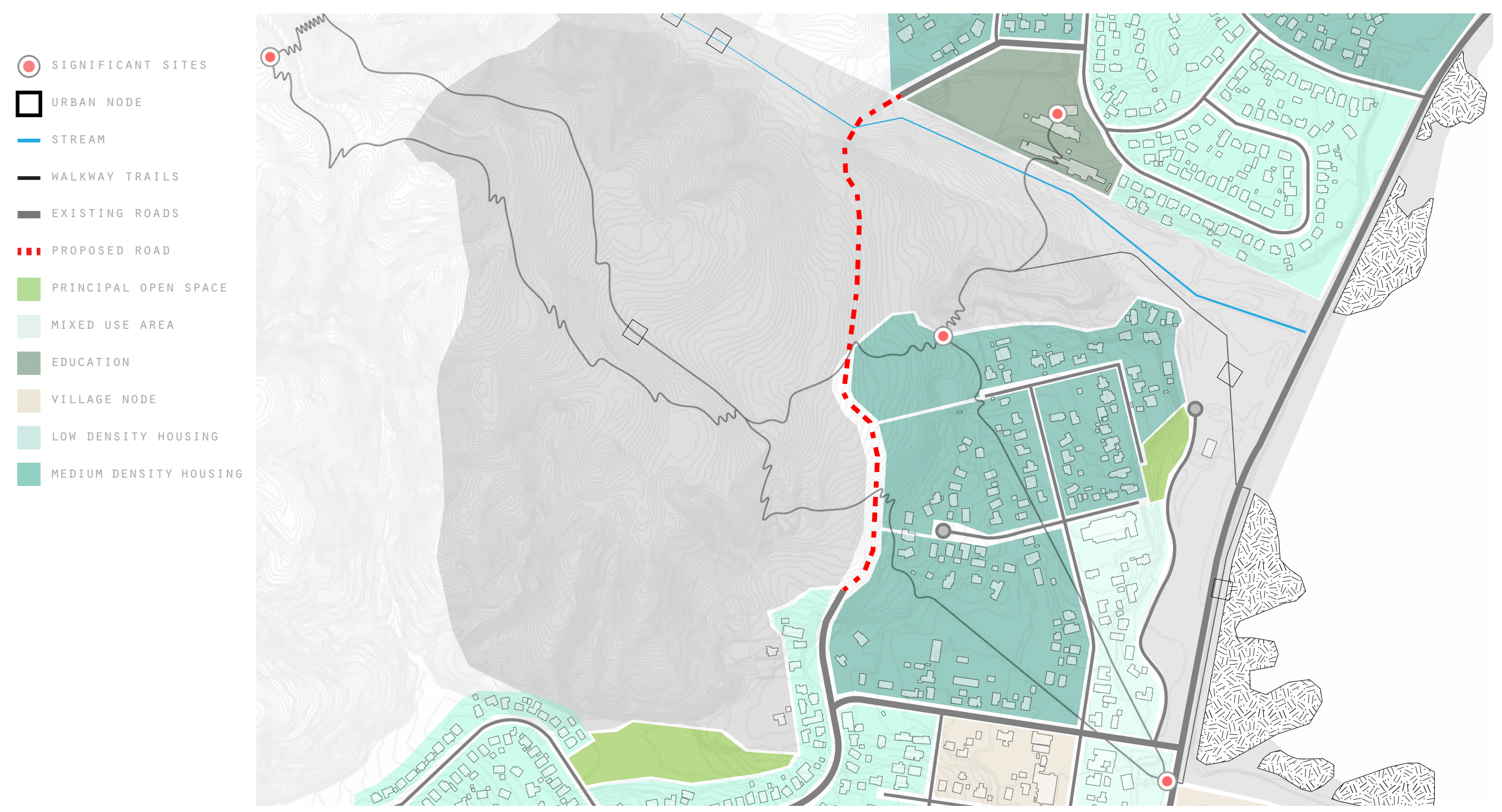


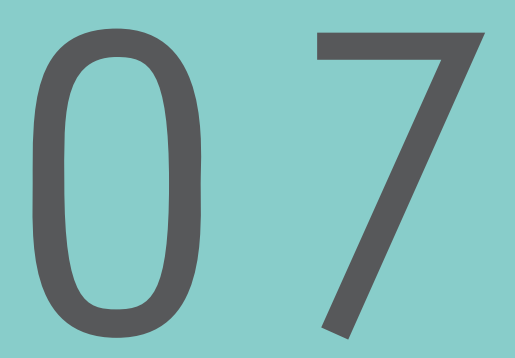

DESIGN RESPONSE

This section demonstrates how the developed method can be applied to simulate a design response. The design response is focused around mitigation and site specific impact analysis. 


\section{DESIGN RESPONSE}

The underpinning intent of this research is to engage with landscape architecture through a digital approach that enables the collaboration between iwi and designers through the use of digital tools, creating a new type of work flow approach within the discipline.

The resulting landscape interventions have been developed by carefully fusing traditional and digital techniques for producing and analysing design. These new methods test how two separate groups can combine understandings of the landscape through a digital process in order to realise development potentials and sustainable management of resource.

The final design for the Takapūwāhia shows how to reintegrate the natural environment with community enabling educative digital and experiential responses to a new environment design that can enhance Ngāti Toa Rangatira's values, identity, and future development aspirations.

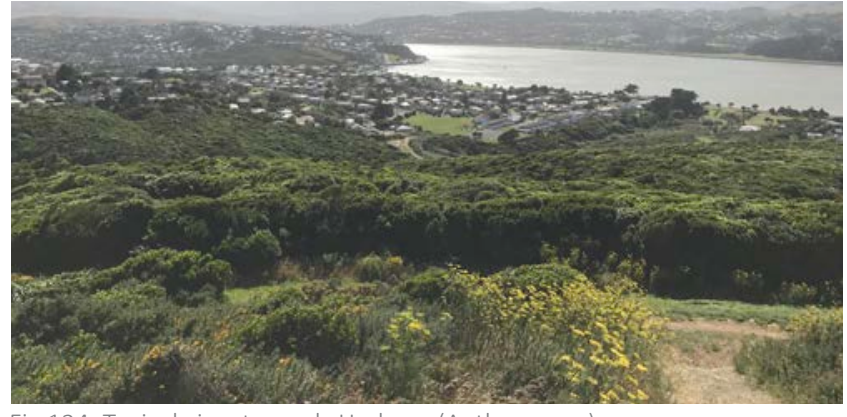

Fig 124. Typical view towards Harbour (Authors own)

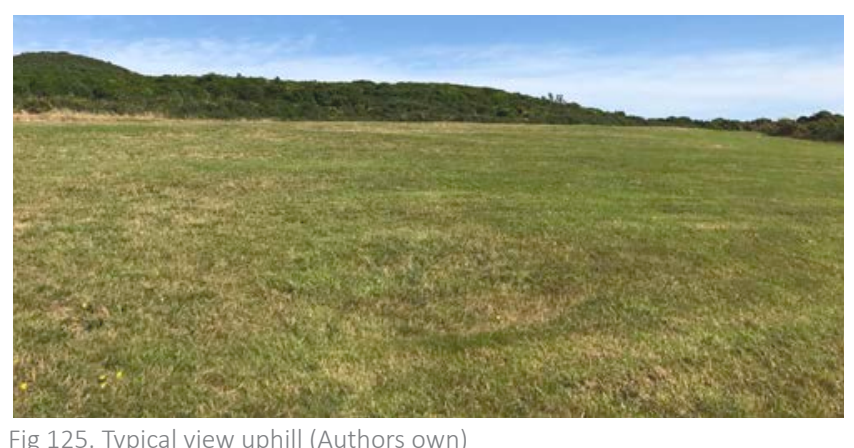

Fig 125. Typical view uphill (Authors own)

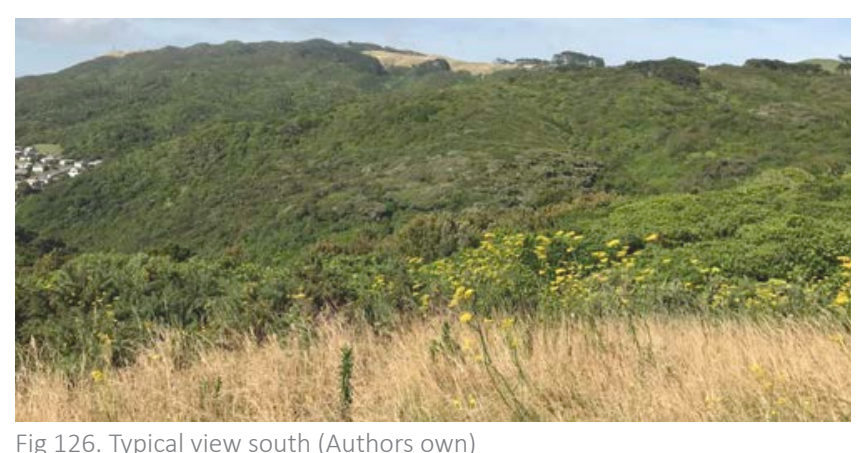

Fig 126. Typical view south (Authors own)

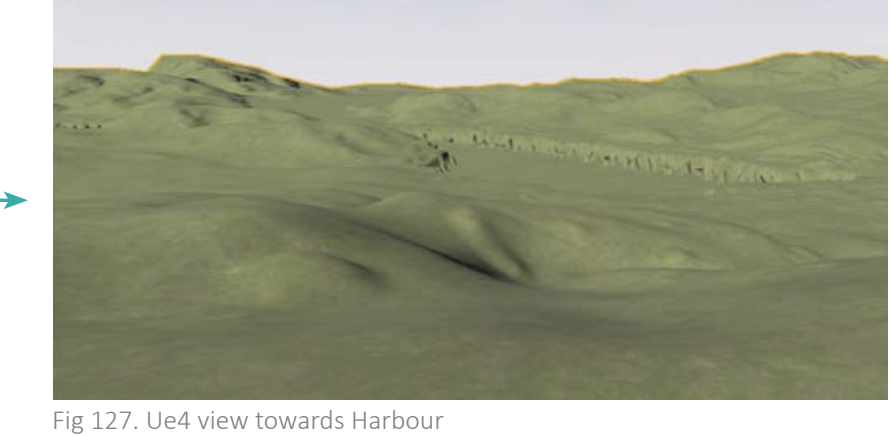

(Authors own)

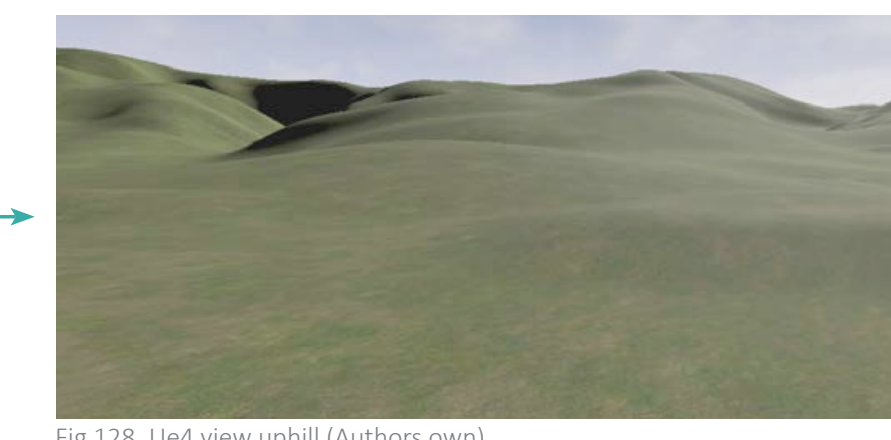

Fig 128. Ue4 view uphill (Authors own)

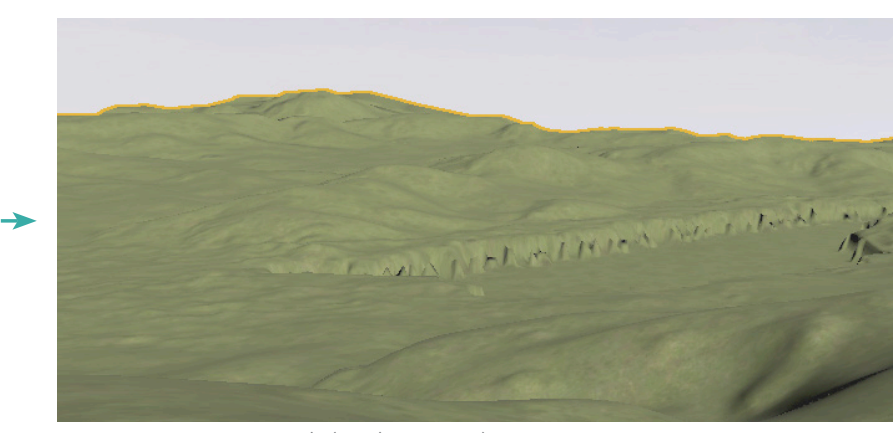

Fig 129. Ue4 view south (Authors own)

TRANSLATING EXISTING LANDFORM TO 3D MODEL 


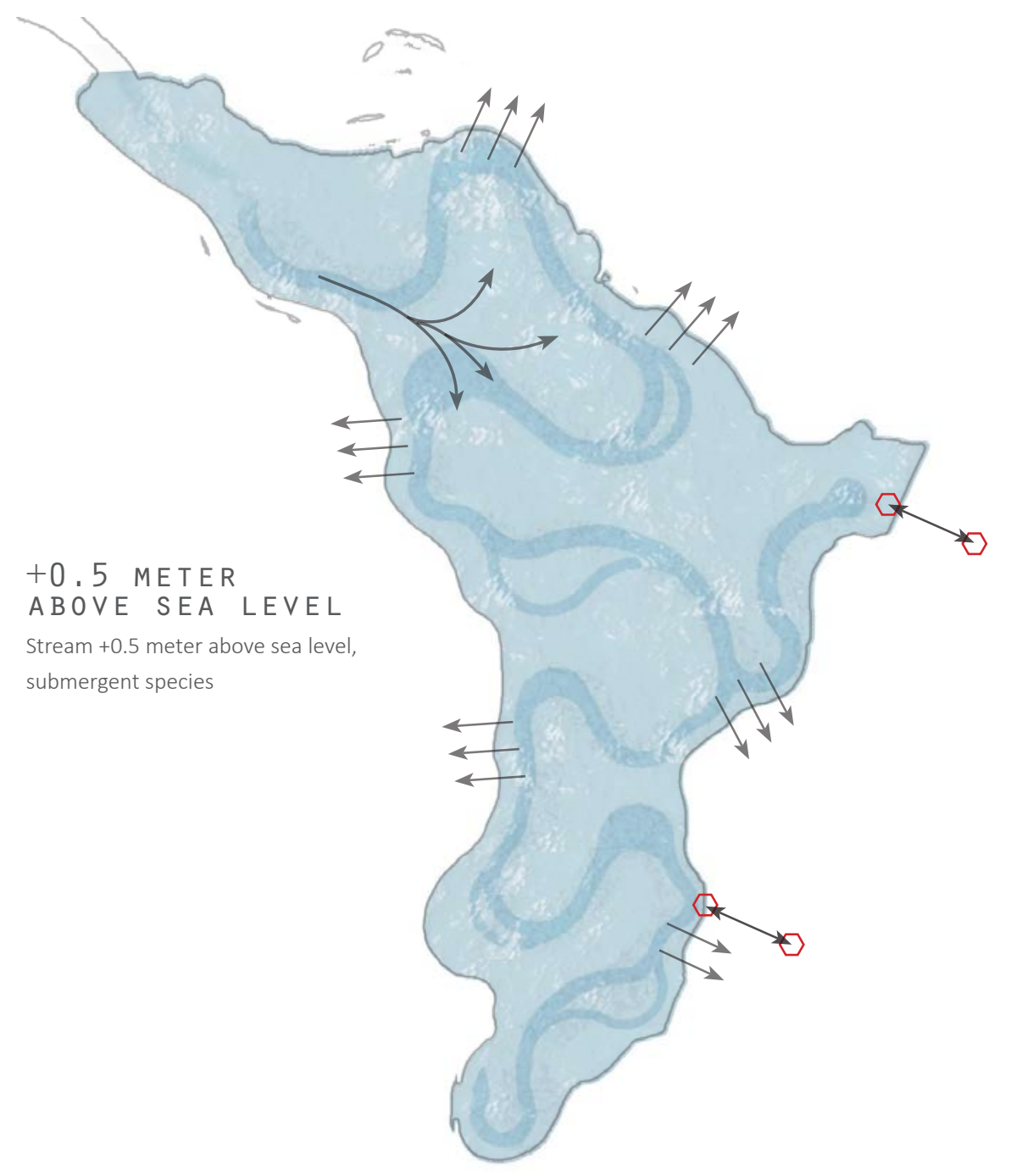

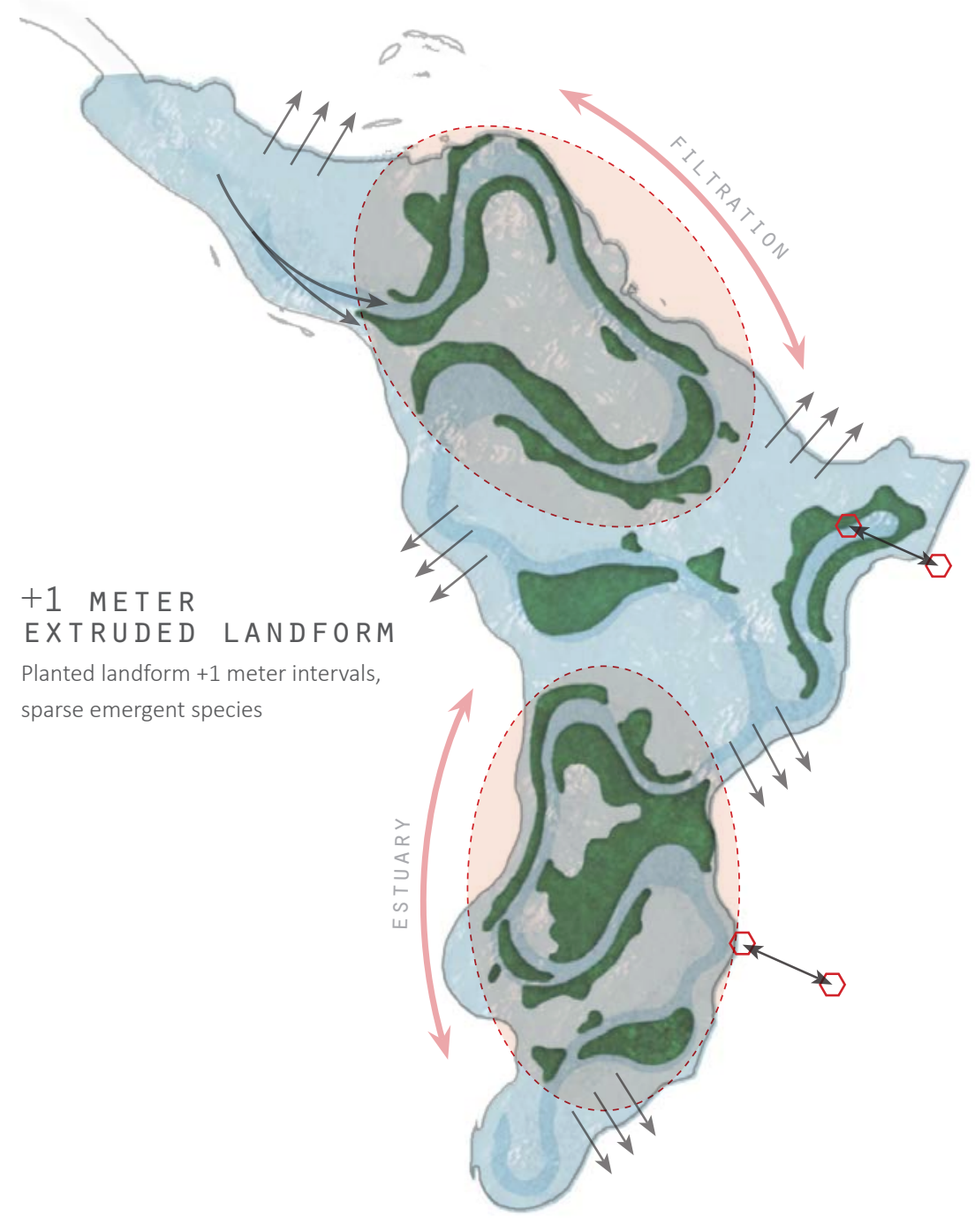




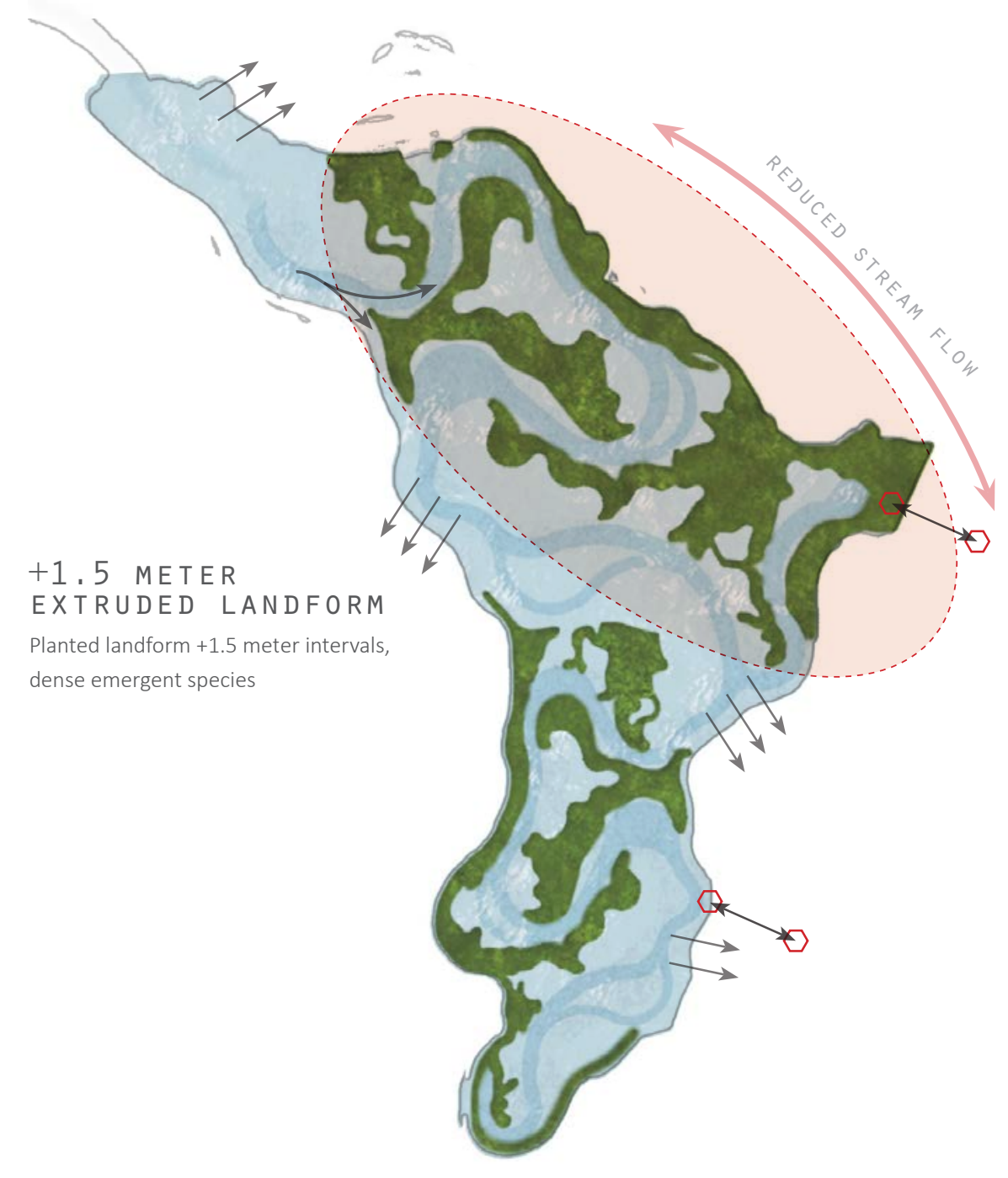

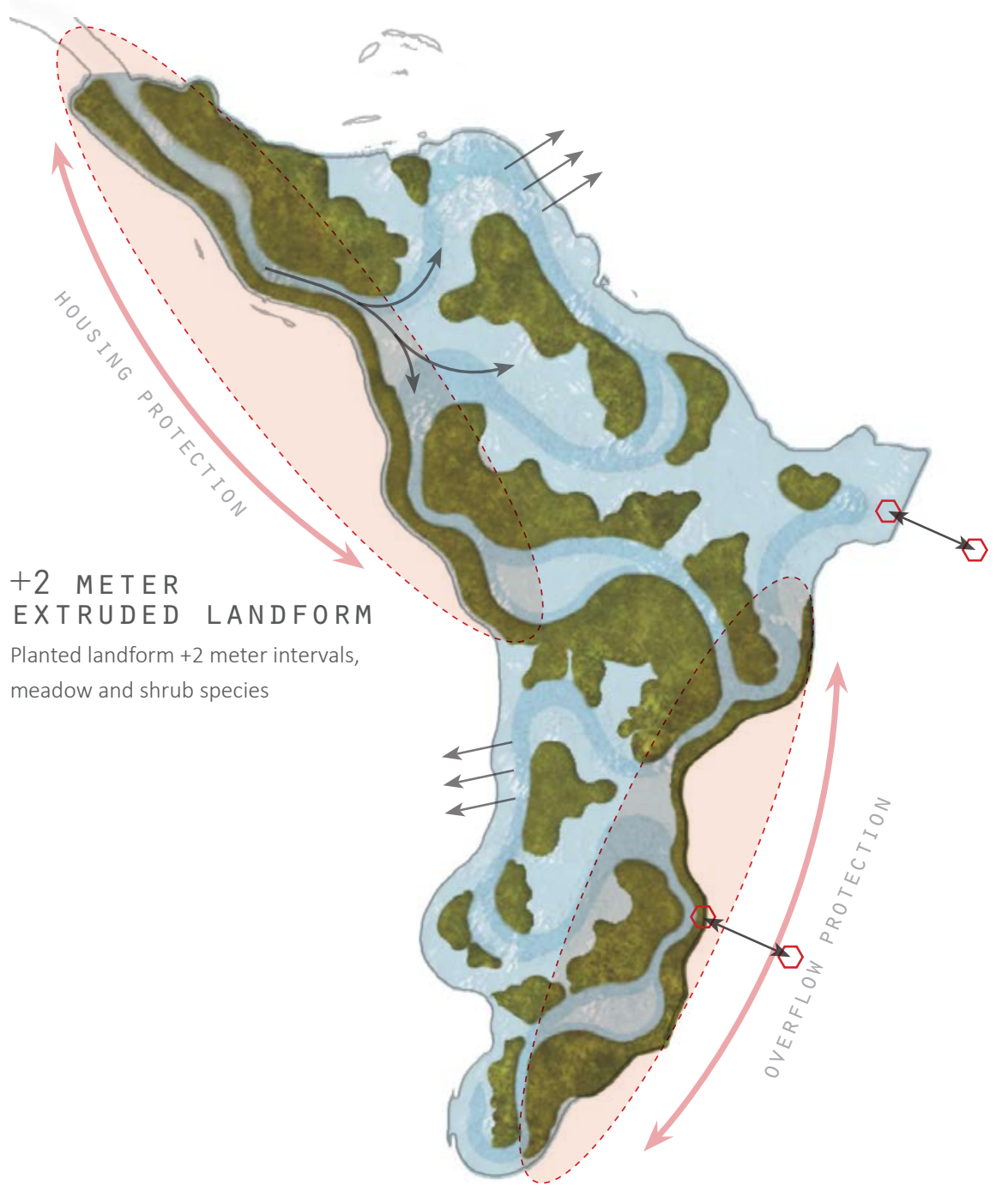

$0 \quad 15 \quad 30$ 
+0.5 METER

ABOVE SEA LEVEL

Stream +0.5 meter above sea level, submergent species

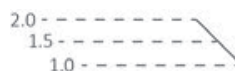

$1.0 \cdot \cdots-1-1$

Community members have identified flooding as an issue

for some properties in Takapūwāhia. This issue affects the kaumātua flats and has potential to impact other properties in the community and pose a health risk

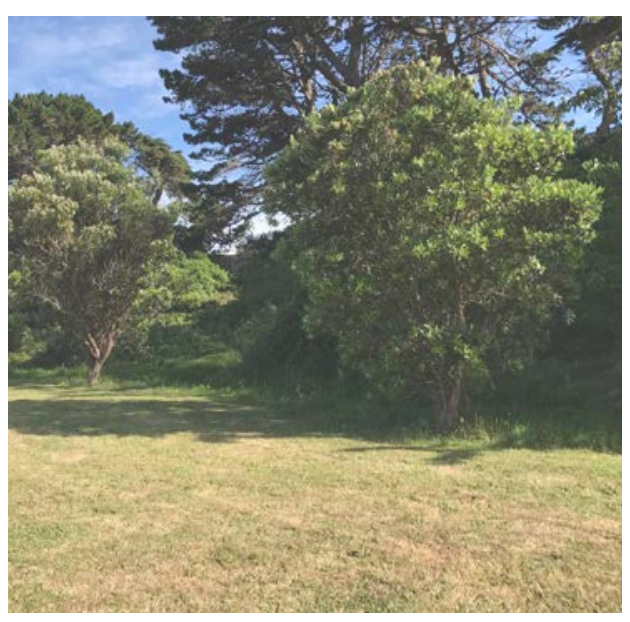

Above Fig 134. Existing land showing boundary extents on Northside (Authors own).

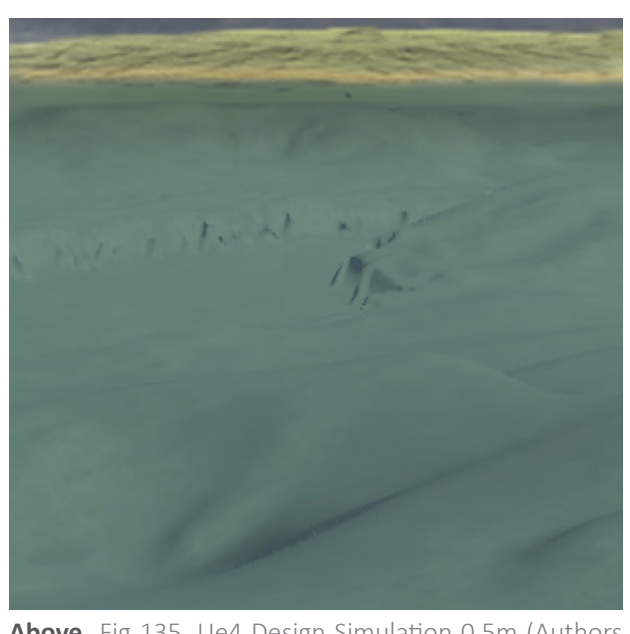

Above Fig 135. Ue4 Design Simulation 0.5m (Authors own)

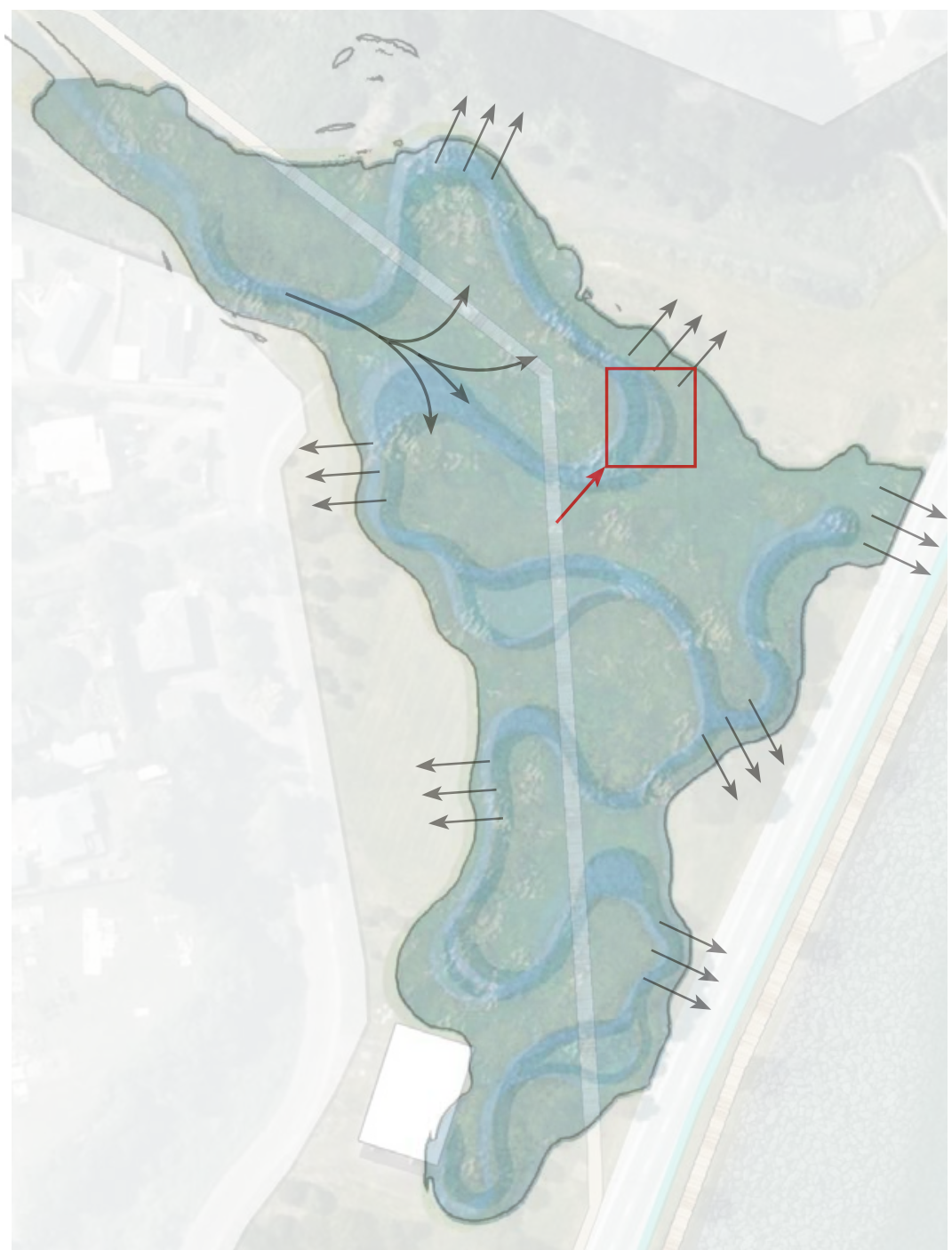

Above Fig 136. Ue4 Design Simulation 0.5m Plan (Authors own)

3D ENVIRONMENT ANALYSIS 
+1 METER

\section{EXTRUDED LANDFORM}

Planted landform +1 meter intervals,sparse emergent species

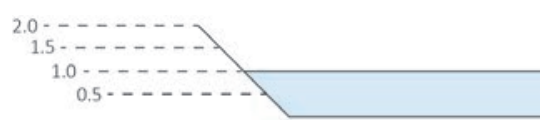

This design is situated primarily on land reclaimed from the original harbour following the shoreline footpath along Titah Bay Main Road spanning the length of the reserve. This is the main daily route for many families and school children and offers potential for interaction with restoration initiatives along the harbour.

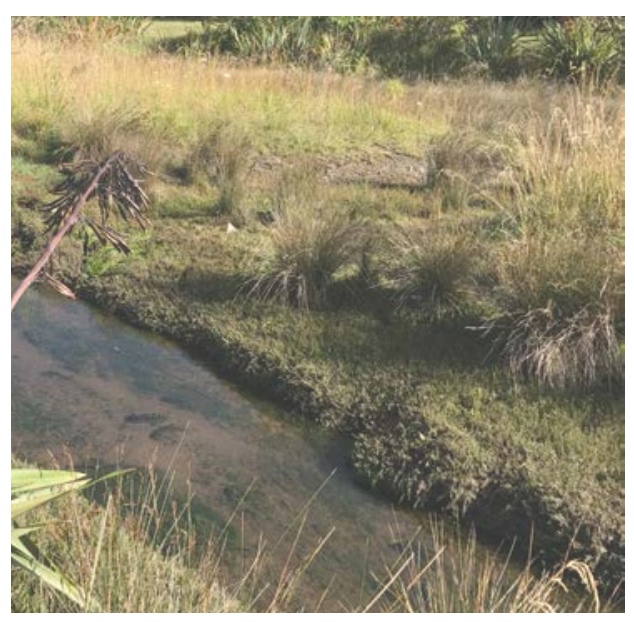

Above Fig 137. Existing land showing central body of stream (Authors own).

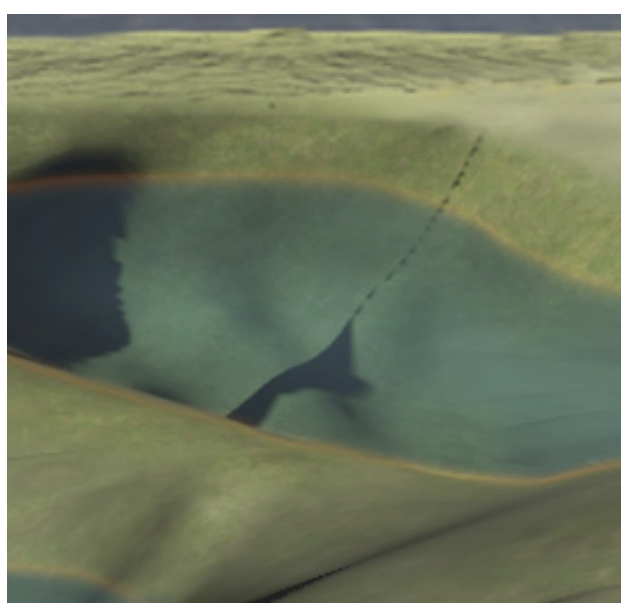

Above Fig 138. Ue4 Design Simulation 1.0m (Authors own

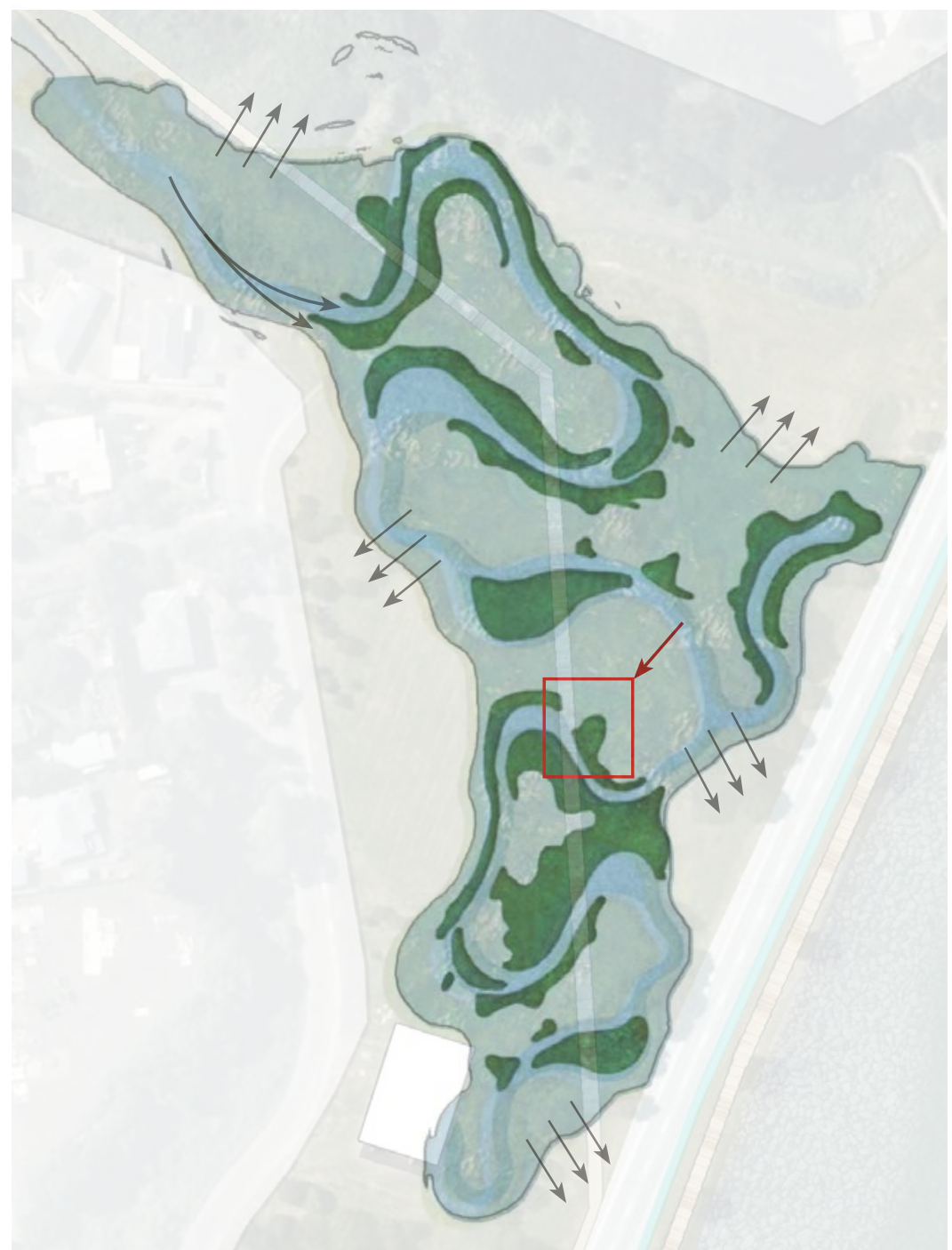

Above Fig 139. Ue4 Design Simulation 1.0m Plan (Authors own) 


\section{+1.5 METER}

EXTRUDED LANDFORM

Planted landform +1.5 meter intervals, dense emergent species

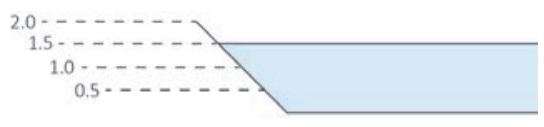

Coastal wetland restoration in this area allows the community and other environmental interests to invest toward the restoration of the Takapūwāhia coast and wetland systems.

The crossing structure has the ability to engage at water level to allow pedestrian intervention particularly school children. This could be further explored with schools where students could be involved in an environmental management program to track the water quality of streams and numbers of species.

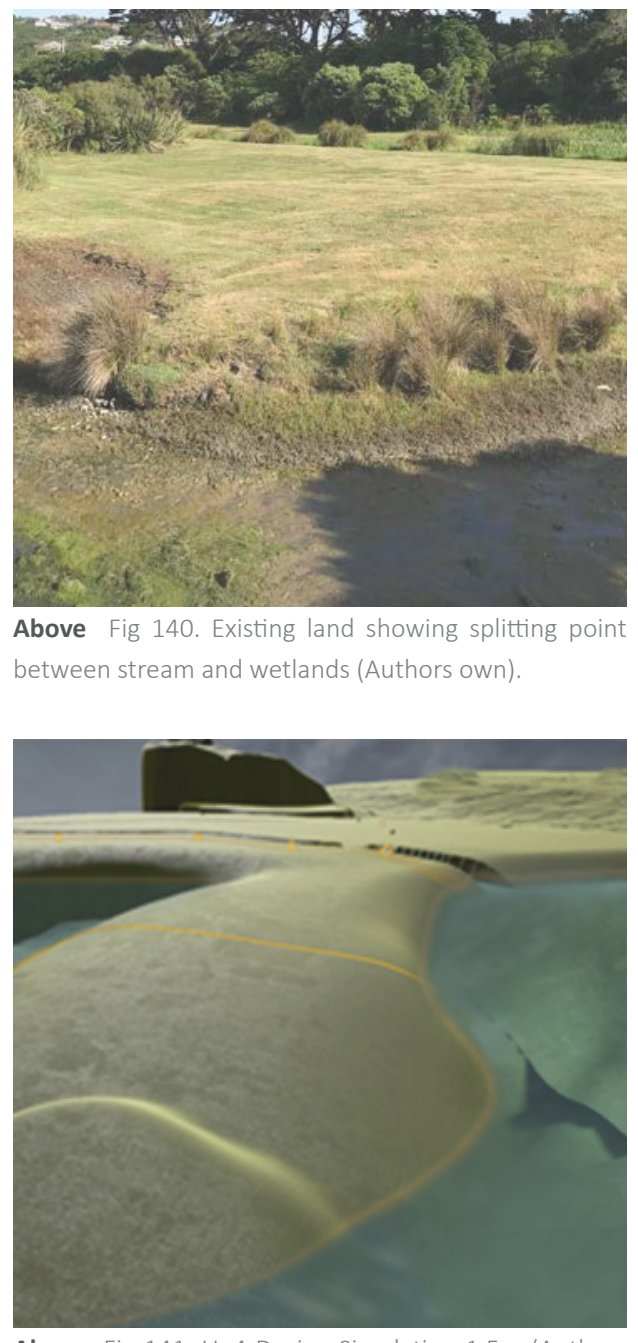

Above Fig 141. Ue4 Design Simulation 1.5m (Authors own)

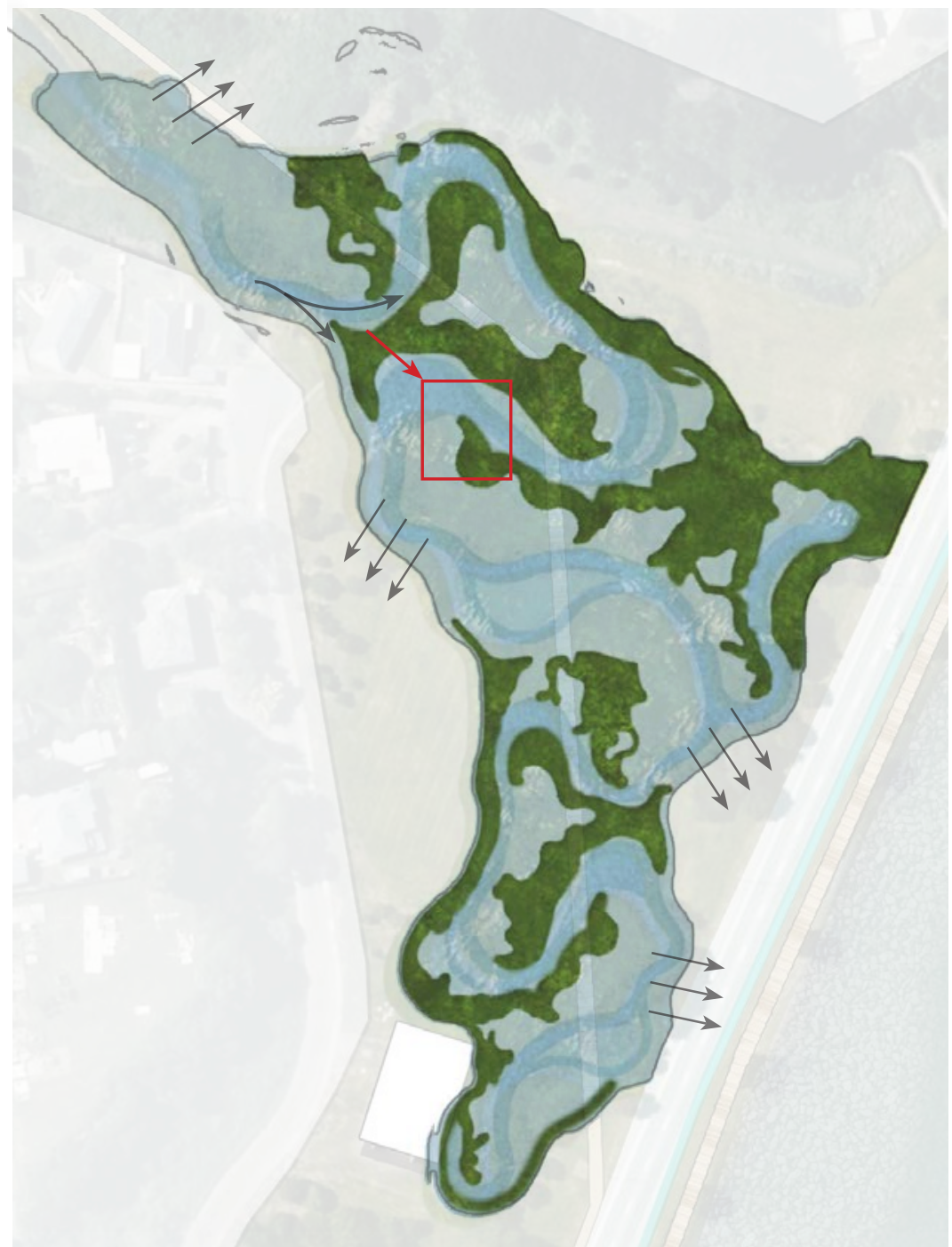

Above Fig 142. Ue4 Design Simulation 1.5m Plan (Authors own)

3D ENVIRONMENT ANALYSIS 


\section{+2 METER}

EXTRUDED LANDFORM

Planted landform +2 meter intervals, meadow and shrub species

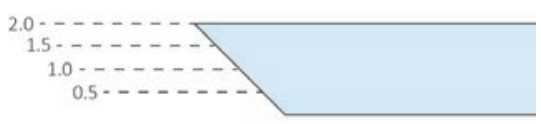

These areas have degraded environmentally so it is important to find ways to aid restoration. The soil in this area is fertile and the relatively low lying plant species situated around these water bodies allows good sun and regulated wind flow for the establishment of new plants. The wetland environment would also provide good nesting and shelter for a variety of native fauna.

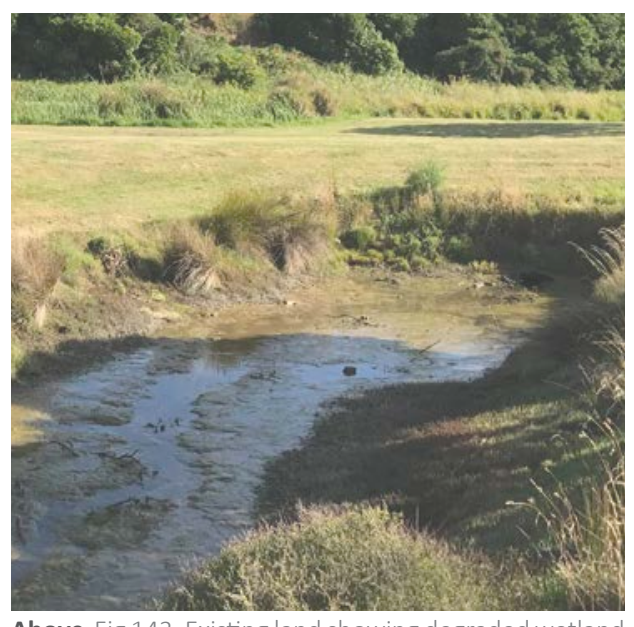

Above Fig 143. Existing land showing degraded wetland environment (Authors own).

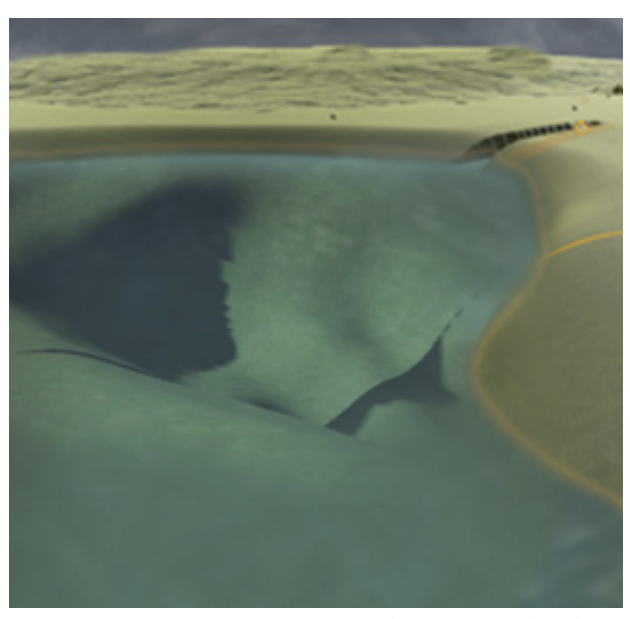

Above Fig 144. Ue4 Design Simulation 2.0m (Authors own)

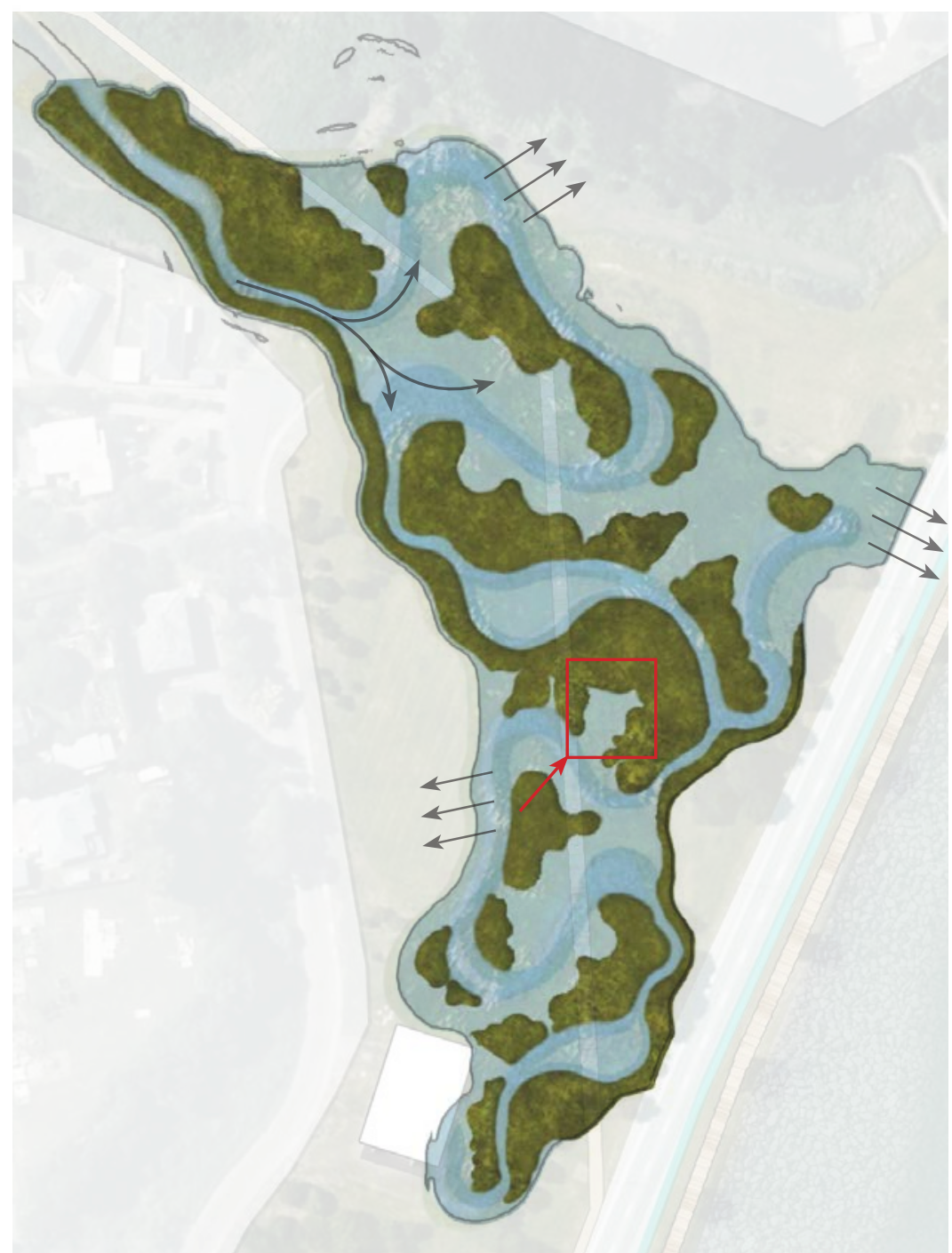

Above Fig 145. Ue4 Design Simulation 2.0m Plan (Authors own) 


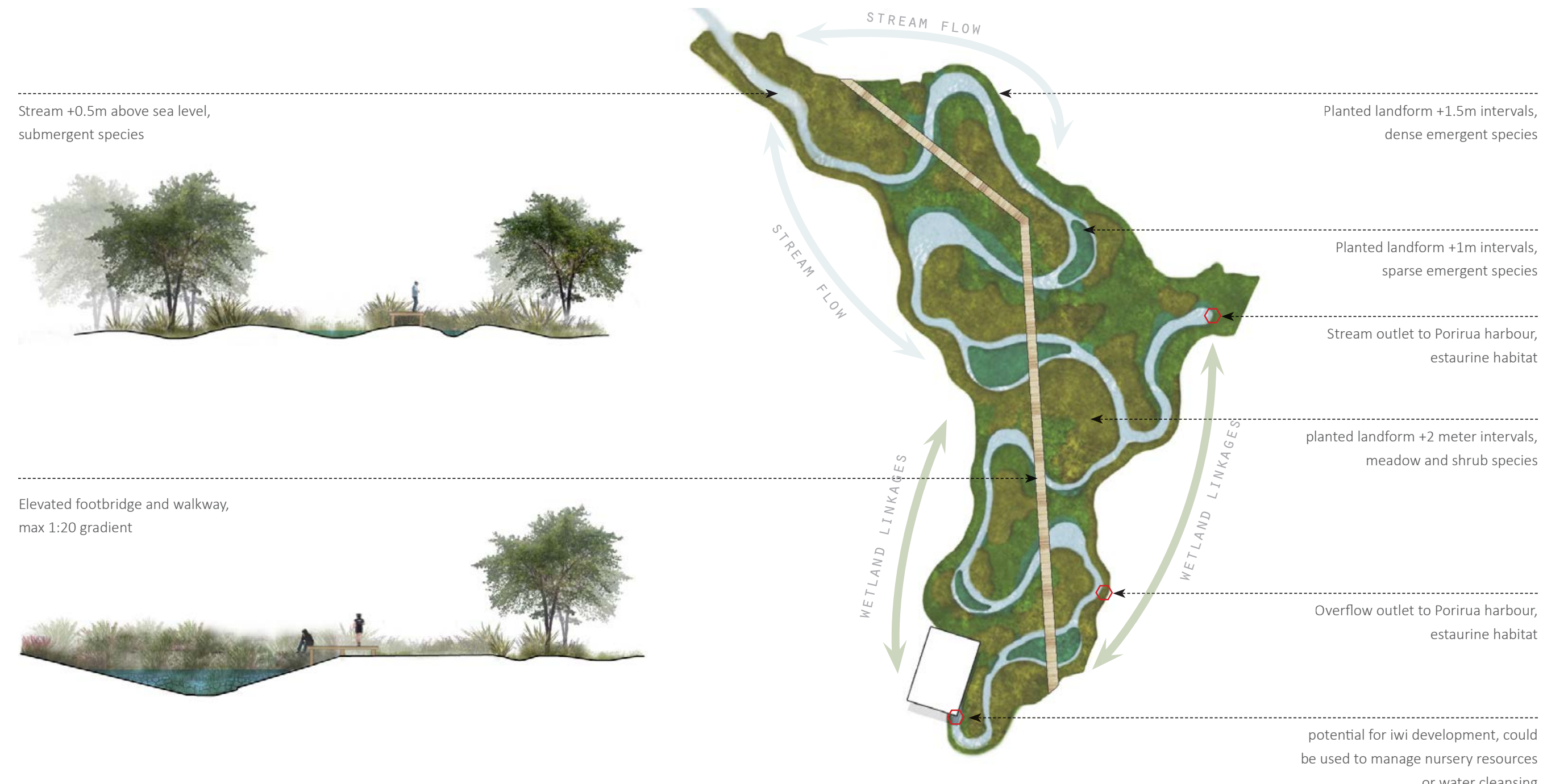

SITE REQUIREMENTS FOR

FLOOD MITIGATION AND WATER PURIFICATION

$0 \quad 15 \quad 30$ 


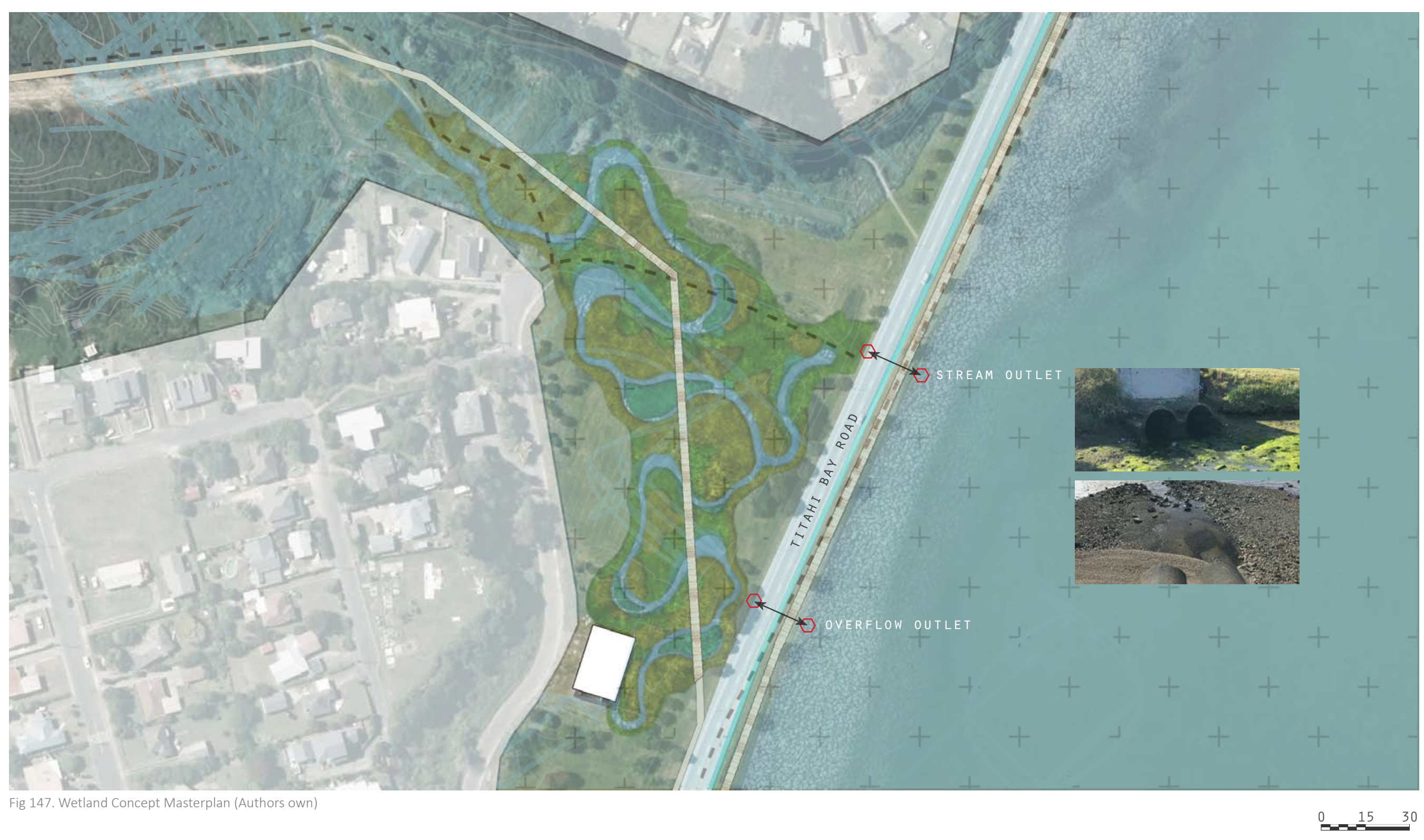


08

DISCUSSION \&

CONCLUSION 


\section{DISCUSSION}

This research explored issues surrounding land management for Māori heightened by growing concerns around climate change and population pressures on natural systems. Because Māori have lost much of their traditional kaitiaki control over their lands and wider customary interests they rely heavily on government agencies and local councils to manage these resources. For Māori the relationship to land ties to strong cultural, spiritual, and genealogical values that are interconnected and embedded.

The research considered these factors and looked for alternatives to the traditional land management approach and found the more integrative hybridised models using new digital tools as being at the forefront. The intent of the research was to develop a method that was transparent and engaging for Māori communities as well as having the flexibility to pull in a diverse array of data.

The methodology was developed into main three main parts; Fieldwork, interactive digital landscape system, and design simulation.
Fieldwork was executed through the GIS mobile data collection app which showed good promise as a tool for capturing point data, and cumulative data over time. It showed particular potential as a tool that communities could use on a day-to-day basis, with an easy to use interface and simple administration

The interactive digital landscape system was developed with photogrammetry capture methods and grasshopper scripting. The terrestrial site specific photogrammetry showed how quality visual data is important if detailed representative simulations of real environments are required.

Design simulations were tested in two separate games engines, where they were evaluated to determine how these platforms would perform and integrate the data input streams. UE4 was chosen over Unity because of the simpler workflow system for designers and an intuitive interface for users to navigate. The simulation accuracy within this was high but heavily reliant on quality data.
As modes of photogrammetry capture improves the translation between different digital platforms will be able to portray higher realism in game engine visualisations.

The design response focused around the Takapūwāhia wetland showed positive potential even with the limited data capture available for this part of the research. Modelling flooding patterns was particularly effective in testing scenarios for further housing development of the wider area and demonstrated detailed site specific information for determining potential planting zones to enhance the wetlands. 
EXISTING SITE ENVIRONMENT

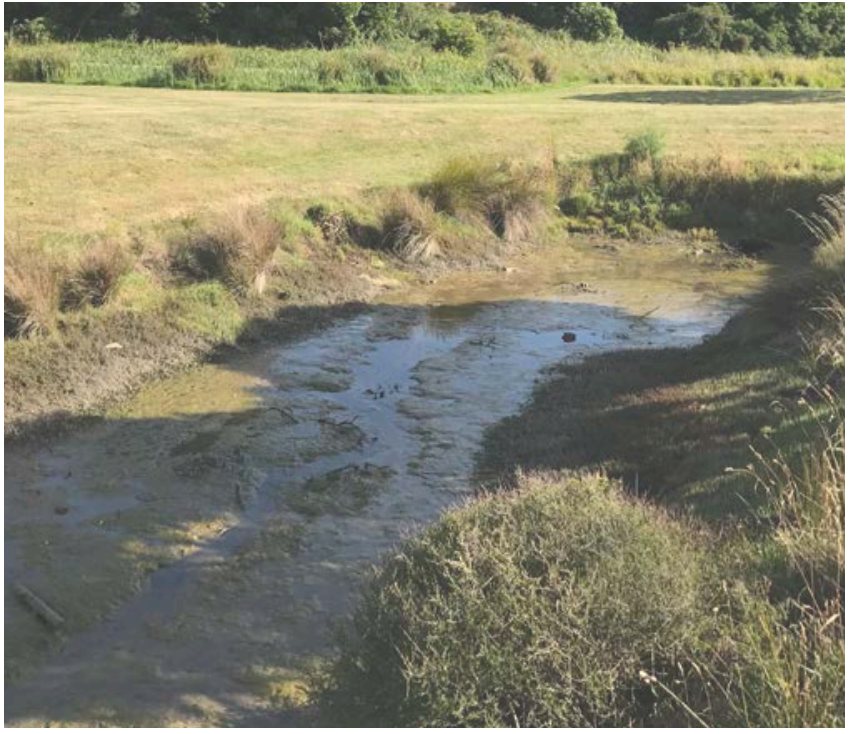

Fig 148. Comparison of Methodology stages (Authors own)
UE4 LANDSCAPE FLOODING SIMULATION

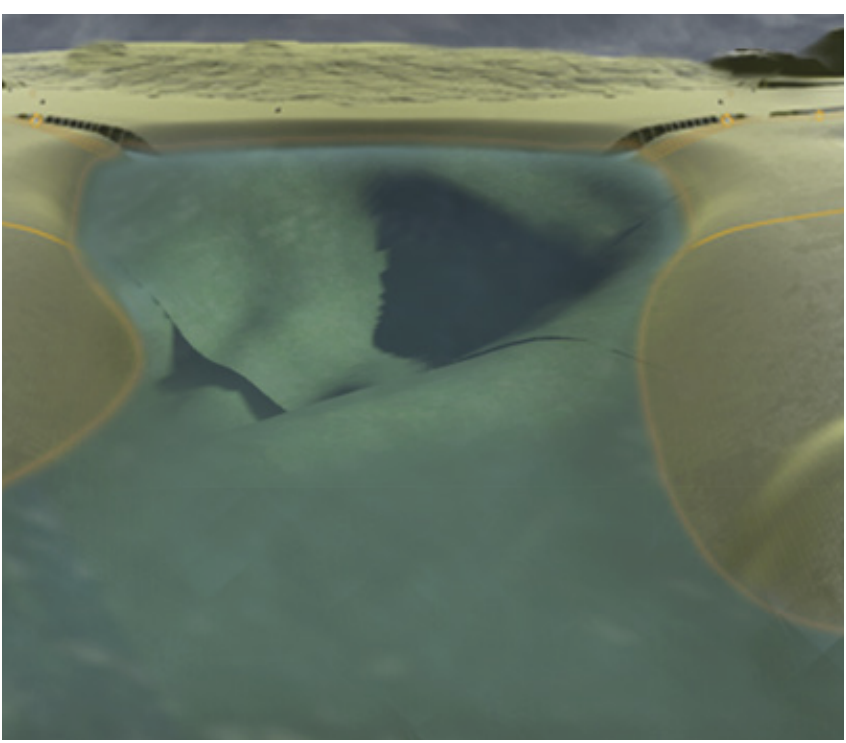

TEXTURING \& PHOTOGRAMMETRY APPLICATION

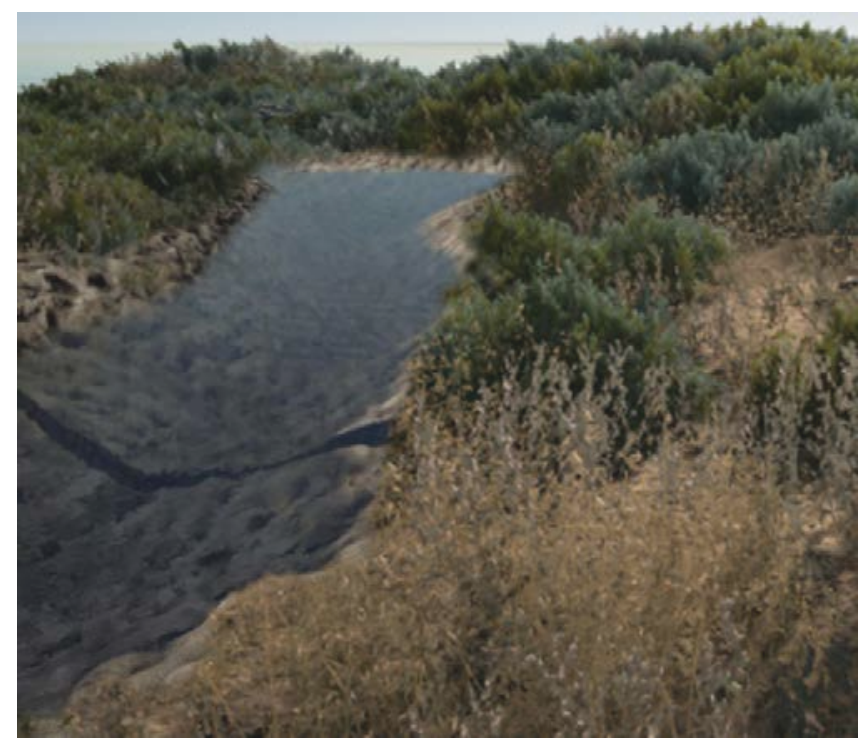

08 


\section{CONCLUSION}

While this type of research is only beginning to become more commonplace through the ubiquity and exposure to digital tool use in relation to Māori kaupapa, its potential is becoming evident as a valuable collaboration method. At the final stages of writing the thesis, the relationship with Ngāti Toa Rangatira has started to gain momentum.

As a test case for a more in-depth study the thesis provides a preliminary model for how ecology and development needs might be evaluated using a digital methodology that allows the capture, analysis, and assessment of data in an easy to understand visual format where iwi can express their cultural values and world view. Furthermore it has shown how digital tools can enable an open collaborative process with single and multiple groups of mana whenua, stakeholders and general community. There is also the potential for other indigenous groups globally to adopt similar attitudes to the tools as a means to effectively manage their relationship to land holdings and general land assets and environment.
Due to the scope of the research, sufficient detail through design testing was not achieved as originally intended. However, the methodology testing and pilot studies have given the opportunity to depict and attempt theoretic scenarios. The research has provided insight into how digital systems may be applied in the field of landscape architecture and that this process can extend into land management proved as an enhanced approach over traditional design methods. Likewise due to the time frame constraints and setbacks occurring with iwi collaboration, the detailing of specific design elements in each intervention were left unexamined to the full extent in the aim to resolve and reflect on probable possibilities.

This research is a journey that is just at the beginning of unlocking new techniques and ways of empowering communities through collaborative design tools. Maori bring a vast amount of cultural knowledge to the table which is why the research has been left open for discussion, and potentially further research. If we were to sum up the conclusions drawn from the pilot studies, developed systems and investigation outlined, it would be that the future approach to land management initiatives must be linked more effectively to digital techniques and tools to ensure a transparent knowledge base among iwi and outside stakeholders. Underlining this new approach is the affordance toward necessity and the form of complementary and dual functioning implementations. 


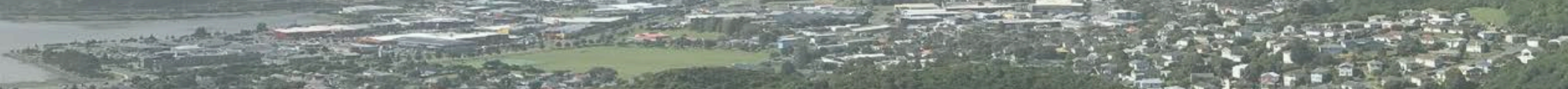

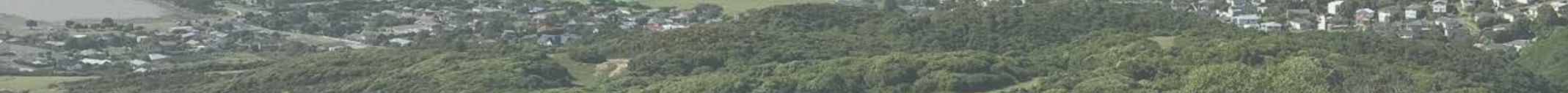

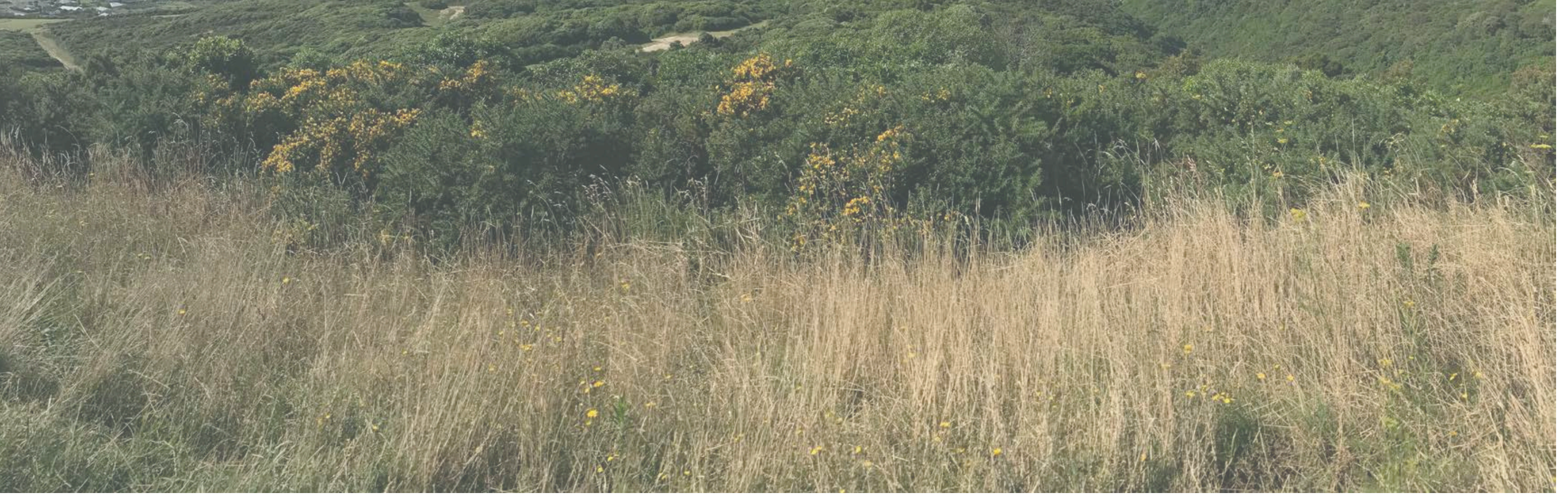




\section{GLOSSARY}

\section{TRANSLATION FROM}

MAORI TO ENGLISH

Atua - God; spirit; supernatural being

Tangata whenua - First people of the land (Tangata being; whenua = land).

Arohatanga - (the notion of care, respect, love, compassion)

Hapu - Subtribe; pregnant

Hinewaoriki - Mother of the kahikatea tree (Podocarpus dacrydioids) and of the matai tree

(P. taxifolia).

Iwi - extended kinship group, tribe, people- often refers to a large group of people descended from a common ancestor and associated with a distinct territory

Kaitiaki - (Verb) to guard; to protect (Noun) guardian; protector

Kaitiakitanga - (environmental guardianship)

Mana - Authority; power; prestige; influence

Mana Whenua - (authority over land and resources)

Manaakitanga - (acts of giving and caring for)

Māori - indigenous people of New Zealand

Mauri - Spiritual life force

Mumuhunga - Mother of the totara tree (Podocarpus to tara)

Papatuanuku - Earth Mother

Parauri - Mother of the tui bird (Prosthemadera novaeseelandiae) .

Rangatira - Chief; either male or female

Rangatiratanga - The exercise or expression of chiefly authority; power; mana.

Ranginui; Ranginui e tu iho nei - Sky Father

Rohe - Tribal area or region

Tane mahuta - Tane, god/guardian of the standing forest

Taonga - Valued, treasured possessions (material, or nonmaterial).

Tapu - Restricted, sacred

Te Ao Hurihuri- The changing world

Te Ao Marama - The full light of day; the cosmogonical realm of being

Te Kore - The void; the cosmogonical realm of potential being

Te Po - The night realm; the cosmogonical realm of becoming

Tikanga - (customary practice, values, protocols)

Tino Rangatiratanga - (self-determination)

Tohunga - Person with superior knowledge or learning in a particular area.

Tupuna - Ancestor; also grandparents, male or female

Urupa - Cemetery

Wairuatanga - (a spiritual dimension)

Wananga (waananga) - Maori school of learning

Whakakotahitanga - (respect for individual differences and participatory inclusion for decision-making)

Whakapapa - (ancestral lineage, genealogical connections, relationships, links to ecosystems)

Whanau - Family; extended family

Whānaungatanga - (family connections)

Whenua - Land; placenta; generic term for Papatuanuku

IN PARENTHESES, THE WORD SPELT IS PRONOUNCED IF A LONG VOWEL WAS PRESENT. THIS IS SOMETIMES DENOTED BY A MACRON. 


\section{LIST OF FIGURES}

all images are authors own unless otherwise stated. REFER TO BIBLIOGRAPH FOR FULL IMAgE REFERENCE LINKS.

\section{Fig 1. Annual Temperature Porirua}

Fig 2. Annual Rainfall Porirua

Fig 3. Annual Gale Days Porirua

Fig 4. Annual Rain Days Porirua

Fig 5. Takapūwāhia North Panorama

Fig 6. Annual Wind Speed NZ - niwa.co.nz

Fig 7. Annual Mean Temperature NZ - niwa.co.nz

Fig 8. Annual Soil Moisture Deficit NZ - niwa.co.nz

Fig 9. Annual Sun Hours NZ - niwa.co.nz

Fig 10. Annual Rainfall NZ - niwa.co.nz

Fig 11. Aerial Perspective - Ian McHarg "Design with Nature"

Fig 12. Performance Analysis - Ian McHarg "Design with Nature"

Fig 13. Bathymetric Diagram Porirua

Fig 14. Plain Windflow Projections

Fig 15. Action Against Oil Drilling Intensifies - archive.indymedia.org.nz

Fig 16. Takapūwāhia Boundary

Fig 17. Porirua Harbour - upload.wikimedia.org

Fig 18. Historic Catch - Takapūwāhia Community Strategy 2014 (Page 9)

Fig 19. Historic Water Simulation

Fig 20. Ngāti Toa Rangatira c.1944 Aerial, c.1954 Perspective - pcc.govt.nz

Fig 21. Maori at Takapūwāhia village, c1909 - pcc.govt.nz

Fig 22. Takapūwāhia Marae - Ibonshor.files.wordpress.com

Fig 23. Te Aro Pā Sketch - resources.stuff.co.nz

Fig 24. Te Aro Pā - resources.stuff.co.nz

Fig 25. Wellington Residential Median Sale Prices - westpac.co.nz
Fig 26. Urban Sale Listings - listings.jonette.co.nz

Fig 27. Urban Rental Listings - listings.jonette.co.nz

Fig 28. State Housing - teara.govt.nz

Fig 29. Kitset Housing - pcc.govt.nz

Fig 30. Whitireia Park - wysiwygpurple.files.wordpress.com

Fig 31. Village Footbridge

Fig 32. Takapūwāhia Trail

Fig 33. Porirua Markets - resources.stuff.co.nz

Fig 34. Ecology VIM - greenlab.cirad.fr

Fig 35. Game Visualisation - Iviz.org

Fig 36. Te Aro Pā in the 1840's - teara.govt.nz

Fig 37. Te Aro Pā Today - heritage.org.nz

Fig 38. Māori Origins

Fig 39. Core Māori Values - Te Aranga Māori Design Principles 2008 (Page 9)

Fig 40. Research Icons

Fig 41. Research Response

Fig 42. Partnership

Fig 43. Takapūwāhia Section

Fig 44. Takapūwāhia Fieldwork

Fig 45. Māra Kai - Takapūwāhia Community Strategy 2014 (Page 21)

Fig 46. MDC Collection Forms

Fig 47. Photogrammetry Flight Zones

Fig 48. Pilot Study Photo Slides

Fig 49. Photogrammetry Screenshots

Fig 50. Poor Photo Angles Diagram 
Fig 51. Photogrammetry Model Oruaiti Pā

Fig 52. Textures Oruaiti Pā

Fig 53. Correct Photo Angles Diagram

Fig 54. Textures Palmer Bay

Fig 55. Photogrammetry Model Palmer Bay

Fig 56. Porirua Region Ue4

Fig 57. ReMake Modelling Screenshots

Fig 58. Pilot Study Screenshots Unity

Fig 59. Unity Workflow Interface

Fig 60. Ue4 Workflow Diagram

Fig 61. Terrain Surface Variations

Fig 62. Refined Grasshopper Scripts

Fig 63. Design Experiments Ue4

Fig 64. Game Interface Ngāti Toa

Fig 65. Climate Simulation Aerial Pilot Study

Fig 66. Climate Simulation 1st Person Pilot Study

Fig 67. Interactive Storytelling Aerial Pilot Study

Fig 68. Interactive Storytelling 1st Person Pilot Study

Fig 79. Modelling Collage 1

Fig 70. Modelling Collage 2

Fig 71. Modelling Collage 3

Fig 72. Land Surveying Existing Bush

Fig 73. Land Surveying Existing Wetland

Fig 74. Land Surveying Existing Stream

Fig 75. Land Surveying Existing Coast

Fig 76. Windflow Scenario Model Projection

Fig 77. Solar Model Projections

Fig 78. Macro Water Runoff Loop

Fig 79. Micro Water Runoff Loop
Fig 80. Public Open Spaces Zoning

Fig 81. Takapūwāhia Vegetation

Fig 82. Tree Palette

Fig 83. Plant Palette

Fig 84. Edge Conditions Coastal Sketch

Fig 85. Edge Conditions Wetland Sketch

Fig 86. Significant Sites

Fig 87. Trails to Significant Sites

Fig 88. Simulated Path 1:12

Fig 89. Simulated Path 1:20

Fig 90. Condition Zoning

Fig 91. Exisitng Zoning

Fig 92. Existing Walkways

Fig 93. Existing Footbridge

Fig 94. Existing Dirt Trail

Fig 95. Landscape Material not Height Blended - answers.unrealengine.com

Fig 96. Footbridge Texturing and Reflection - answers.unrealengine.com

Fig 97. Ue4 Dirt Trail 1:20 Gradient - 80.Iv

Fig 98. Ue4 Grass Texture

Fig 99. Ue4 Water Texture

Fig 100. Ue4 Lime Chip Texture

Fig 101. Recreation Strategy

Fig 102. Existing Bush Edge Condition

Fig 103. Foliage Environment - i.imgur.com

Fig 104. Bush Section 1:200

Fig 105. Existing Stream Condition

Fig 106. Difference in Landscape Height - answers.unrealengine.com

Fig 107. Stream Section 1:200

Fig 108. Existing Wetland Condition 
Fig 109. Landscape Auto Material Pack - cgrecord.net

Fig 110. Wetland Section 1:200

Fig 111. Exisitng Coastal Condition

Fig 112. Lost Coast - techreport.com

Fig 113. Coastal Section 1:200

Fig 114. High Density Scenario

Fig 115. Medium Density Scenario

Fig 116. Low Density Scenario

Fig 117. Ue4 Main Roads

Fig 118. Ue4 Residential Intersections

Fig 119. Ue4 Residential Streets

Fig 120. ReMake Brick Paving

Fig 121. ReMake Concrete Paving

Fig 122. ReMake Aggregate Paving

Fig 123. Infrastructure Strategy

Fig 124. Typical view towards Harbour, Takapūwāhia

Fig 125. Typical view uphill, Takapūwāhia

Fig 126. Typical view South, Takapūwāhia

Fig 127. Ue4 view towards Harbour, Takapūwāhia

Fig 128. Ue4 view uphill, Takapūwāhia

Fig 129. Ue4 view South, Takapūwāhia

Fig 130. Water Simulation $0.5 \mathrm{~m}$

Fig 131. Water Simulation 1.0m

Fig 132. Water Simulation $1.5 \mathrm{~m}$

Fig 133. Water Simulation $2.0 \mathrm{~m}$

Fig 134. Existing land showing boundary extents on Northside

Fig 135. Ue4 Design Simulation 0.5m

Fig 136. Ue4 Design Simulation 0.5m Plan

Fig 137. Existing land showing central body of stream
Fig 138. Ue4 Design Simulation 1.0m

Fig 139. Ue4 Design Simulation 1.0m Plan

Fig 140. Existing land showing splitting point between stream and wetlands

Fig 141. Ue4 Design Simulation 1.5m

Fig 142. Ue4 Design Simulation 1.5m

Fig 143. Existing land showing degraded wetland environment

Fig 144. Ue4 Design Simulation 2.0m

Fig 145. Ue4 Design Simulation 2.0m Plan

Fig 146. Wetland Design Strategy

Fig 147. Wetland Concept Masterplan

Fig 148. Comparison of Methodology stages

Fig 149. Panorama facing East

Fig 150. Ngāti Toa Vision Statement- Takapūwāhia Community Strategy 2014 (Page 13)

Fig 151. Public Transport Porirua (PCC, Porirua Transportational Strategy, 2012, Page 35).

Fig 152. Takapūwāhia Street Names (Google Maps, 2017).

Fig 153. Porirua Network (PCC, Recreation + Open Space Strategy, 2012, Page 21).

Fig 154. Strategy Context (PCC, Recreation + Open Space Strategy, 2012, Page 5).

Fig 155. A comparison of Features. (Wilder, O'Meara, Monti, \& Nabhan, 2016, Page 3).

Fig 156. Wetland System (Takapūwāhia Community Strategy 2014, Page 19).

Fig 157. Traditional Knowledge and Beliefs (Harmsworth and Awatere, Page 275).

Fig 158. Māori outcome goals and classes (Harmsworth and Awatere, Page 280)

Fig 159. Porirua Regional Topo Map (NZ Topo Map, 2017).

Fig 160. GIS Mobile Data Collection - Server Mapping View.

Fig 161. Water Runoff Script

Fig 162. Heightmap Surface Script

Fig 163. Pathfinder Script 


\section{BIBLIOGRAPHY}

Aotearoa Independent Media Centre. (2011). Action Against Oil Drilling Intensifies. Retrieved from http://archive.indymedia.org.nz/article/79531/action-against-oil-drilling-intensifies.html

Aboriginal Health Tour. (2013). Takapūwāhia Marae. Retrieved from https://Ibonshor. wordpress.com/2013/09/30/te-runanga-o-ngati-toa-rangatira-takapuwahla-friday-september-27th/

Appleyard, D. (1977). Understanding Professional Media: Issues, Theory, and a Research Agenda. (I. Altman, \& J. Wohlwill, Eds.) Human Behaviour and Environment, Vol. 1, 43-88

Buck, P. (1950). The Coming of the Māori. Wellington: Whitcombe and Tombs Ltd. Butt, N., Epps, K., Overman, H., Iwamura, T., \& Fragoso, J. (2015). Assessing Carbon Stocks using Indigenous Peoples field measurements in Amazonian Guyana. Forest Ecology and Management, 338, 191-199.

Detocroix . (2014). Footbridge Texturing and Reflection. Retrieved from https:// answers.unrealengine.com/storage/temp/21494-screenshot+2014-11-18+10.05.16. png

Detocroix . (2014). Landscape material not height blended correctly. Retrieved from https://answers.unrealengine.com/storage/temp/21493-screenshot+2014-11-18+10.05.16.png

DOC. (1994). Māori Conservation Ethic: a Ngāti Kahungunu Perspective. Wellington: Department of Conservation.
Coster, D. (2016). Te Aro Pā Sketch. Retrieved from https://resources.stuff. co.nz/content/dam/images/1/a/s/1/t/y/image.related.StuffLandscapeSixteenByNine.620x349.1arrti.png/1459815719407.jpg

Google Maps. (2017). Takapūwāhia Street Names. Retrieved from https:// www.google.com/maps/place/Takapuwahia,+Porirua+5022,+New+Zealand /@-41.1200247,174.8211391,15z/data=!3m1!4b1!4m5!3m4!1s0x6d3f53a6a708bee5:0x500ef6143a2f2fo!8m2!3d-41.1250918!4d174.8332753?hl=en

Harmsworth, G., \& Awatere, S. (n.d.). Indigenous Māori Knowledge and Perspectives of Ecosystems. Landcare Research. 275-280.

Herlihy, P. (2003). Participatory Research Mapping of Indigenous Lands in Darien, Panama. Human Organization, 62, 315-331.

Heke, N. (2008). Te Aro Pā Today. Retrieved from http://www.heritage.org.nz/content/images/register/7771a_lg.jpg?w=622\&h=350\&scale=both

Jackson, J. (1984). Discovering the Vernacular Landscape. New Haven: Yale University Press.

Luzar, J., Silvius, K., Overman, H., Giery, S., Read, J., \& Fragoso, J. (2011). Large-scale Environmental Monitoring by Indigenous Peoples. BioScience Oxford Journals, 61, 771-781.

Maidment, R., \& Bronstein, R. (1973). Simulation Games: Design and Implementation. 19-28.

Marsden, M. (1975). God, Man and Universe: A Māori View. Wellington: Hicks Smith \& Sons Ltd. 
McHarg, I. (1995). Aerial Perspective. Retrieved from https://static1.

squarespace.com/static/52c2e989e4b0c7e767966d1a/t/576427a28419c-

28ad942aa90/1466181599730/

McHarg, I. (1995). Design with Nature. New Jersey: John Wiley \& Sons, Inc.

McHarg, I. (1995). Performance Analysis. Retrieved from https://s-media-cache-ak0. pinimg.com/236x/6b/c0/80/6bc08080ef170d062854e01388900d84.jpg

Meason, G. (1828). On The Landscape Architecture of the Great Painters of Italy. Retrieved 07 06, 2016, from https://archive.org/details/onlandscapearchi00meas. Mielants, H., \& Mielants, E. (n.d.). The importance of Simulation as a Mode of Analysis. Sociology \& Anthropology, 310-311.

Murray, C. (2015). Difference in Landscape Height. Retrieved from https://answers. unrealengine.com/storage/temp/32780-cap39.jpg

NICOGGRAPH. (2013). Ecology VIM. Retrieved from http://greenlab.cirad.fr/Prize. htm

NIWA. (2017). Annual Mean Temperature NZ. Retrieved from https://www.niwa. co.nz/static/climate/monthtodatetemp.png?1234

NIWA. (2017). Annual Rainfall NZ. Retrieved from https://www.niwa.co.nz/static/ climate/monthtodatesun.png?1234

NIWA. (2017). Annual Soil Moisture Deficit NZ. Retrieved from https://www.niwa.

co.nz/static/climate/smd_map.png?1234
NIWA. (2017). Annual Sun Hours NZ. Retrieved from https://www.niwa.co.nz/static/ climate/monthtodaterain.png?1234

NIWA. (2017). Annual Wind Speed NZ. Retrieved from http://www.climateoutcome. kiwi.nz/uploads/1/7/4/3/17431675/7271562_orig.png

Norman, E. Te Aro Pā in the 1840's. Retrieved from http://www.teara.govt.nz/en/ artwork/13194/te-aro-pa

NZ Topo Map. (2017). Porirua Regional Topo Map. Retrieved from http://www. topomap.co.nz/NZTopoMap/nz42734/PORIRUA/

O.Riedl, M., \& Bulitko, V. (n.d.). Interactive Narrative: An Intelligent Systems Approach. Al Magazine, 11.

Pacheco-Vega, R. (2014, June 12). On the Importance and Relevance of Fieldwork. Retrieved 07 02, 2016, from Raul Pacheco.

Pataka Museum Collection. Maori at Takapūwāhia village, c1909. Retrieved from http://www.pcc.govt.nz/About-Porirua/Porirua-s-heritage/Porirua-s-suburbs/ Porirua-City-Centre--Elsdon-and-Takapuwahia/Historic-site--Takapuwahia-Village

Pataka Museum Collection. Ngāti Toa Rangatira c.1944 Aerial, c.1954. Retrieved from http://www.pcc.govt.nz/About-Porirua/Porirua-s-heritage/Porirua-s-suburbs/ Porirua-City-Centre--Elsdon-and-Takapuwahia/History-of-Porirua-City-Centre 
PCC. (2012). Porirua Transportational Strategy. Porirua: Porirua City Council.

PCC. (2012). Recreation + Open Space Strategy. Porirua: Porirua City Council.

PCC. (n.d.). Historic site: Takapuwahia Village. Retrieved 08 02, 2016, from Porirua City Council.

Pje Patron. (2014). Foliage Environment. Retrieved from http://i.imgur.com/gpd-

vXrS.png

Pōmare, M. (2005, February 08). Ngāti Toarangatira. Retrieved February 12, 2017, from Te Ara- the Encyclopedia of New Zealand.

Porirua City Council. (2010). Kitset Housing. Retrieved from http://www.pcc.govt.

nz/About-Porirua/Living-in-Porirua-City/Housing

Rangatira, N. T. (2010). Treaty Information- Overview of Ngāti Toa Claims. Retrieved 0215,2017

Rangatira, N. T. (2012). Deed of Settlement of Historical Claims Treaty of Waitangi Settlement. Wellington: Toa Rangatira Trust \& The Crown.

Rigney, R. (2013). Game Visualisation. Retrieved from https://www.wired.

com/2013/09/valley-benchmark/

Schwimmer, E. (1966). The World of the Māori. Wellington: A.H. \& A.W. Reed.

Sheppard, S. (2008). Local Climate Change Visioning: A New Process for Community Planning and Outreach Using Visualization Tools. Plan Canada.
Sheppard, S., Shaw, A., Flanders, D., \& Burch, S. (2008). Can Visualisation Save the World? - Lessons for Landscape Architects from Visualizing. Beitraege, 17.

Steering Committee. (2008, April 08). Te Aranga Māori Cultural Landscape Strategy. Retrieved 06 07, 2016, from Te Aranga.

Takapūwāhia- He Rautaki ā-hāpori. (2014). Porirua: Te Rūnanga o Toa Rangatira Inc. Te Puni Kōkiri. (2016, December 22). Māori Housing Network. Retrieved 02 15, 2017

Timutimu, R. (2014). State Housing. Retrieved from http://www.maoritelevision. com/sites/default/files/styles/news_article_full/public/news_article/BUG\%2OHOUSING\%2OHOUSING.png?itok=mxrQCtci

TVNZ, W. (Director). (2014). The Fight for the Return of the Burial Grounds of Ngāti Te Ata [Motion Picture].

Valve Corporation. (2005). Lost Coast. Retrieved from https://upload.wikimedia.org/ wikipedia/en/8/89/Lost_Coast_HDR_comparison.png

Vea Games. (2015). Dirt Trail Edge Condition. Retrieved from https://80.Iv/articles/ autometic-landscape-material-for-ue4/

Vea Games. (2016). Landscape Auto Material Pack. Retrieved from http://1 bp.blogspot.com/-uLy9xnurYXA/VkGUJ4aWmNI/AAAAAAABeKo/MEh6dCg73zw/ w1200-h630-p-k-nu/Landscape\%2BAuto\%2BMaterial\%2BPack\%2Bfor\%2BUnreal\%2BEngine\%2B4\%2Bby\%2BVEA\%2BGames.jpg 
Westpac. (2013). Wellington Residential Median Sale Prices. Retrieved from https:// www.westpac.co.nz/assets/images/Wellington-heat-map.jpg

Wellington Rental Market Analysis. (2016). Urban Rental Listings. Retrieved from http://listings.jonette.co.nz/blog/wellington-urban-shortage.html

Wellington Rental Market Analysis. (2016). Urban Sale Listings. Retrieved from http://listings.jonette.co.nz/blog/wellington-urban-shortage.html

Whitfield, D. (2016). Porirua Markets. Retrieved from https://resources.stuff. co.nz/content/dam/images/1/9/i/t/w/m/image.related.StuffLandscapeSixteenByNine.620x349.194s26.png/1454298906320.jpg

Wiki, R. (1994). Unpublished Submission to Northland Regional Council. Northland: Ngati Rehia.

Wilder, B., O'Meara, C., Monti, L., \& Nabhan, G. (2016). The Importance of Indigenous Knowledge in Curbing the loss of Language and Biodiversity. BioScience Advance.

Winter, C. (2015). Te Aro Pā Sketch. Retrieved from https://resources.stuff. co.nz/content/dam/images/1/7/c/8/z/z/image.related.StuffLandscapeSixteenByNine.620x349.17avzf.png/1444254016657.jpg

Wojtas, A. (2009). Porirua Harbour. Retrieved from https://upload.wikimedia.org/ wikipedia/commons/8/80/Porirua_Harbour.jpg
Wysiwygpurple's Blog. (2016). Whitireia Park. Retrieved from https://wysiwygpurple.files.wordpress.com/2016/02/img_7998.jpg

Zube, E., Sell, J., \& Taylor, J. (1982). Landscape Perception: Research, Application, and Theory. Landscape Planning, Vol. 9, 1-33. 


\section{APPENDIX}

Tirohanga Whakamua - Vision

Takapūwāhia Marae will continue to function as the cultural and spiritual centre of the Iwi, and the ability of whānau to practise traditional customs within the community will be enhanced.

Descendants of Ngāti Toa will be empowered to continue to live at Takapüwähia, and a safe environment will be fostered for whānau and tamariki.

Te Reo Māori will be fostered amongst families and shown value in the community in tangible ways. Takapūwāhia will be a creative and educated community, and opportunities for higher education will be encouraged

"A healthy harbour and waterways"1 - Te Awarua o Porirua will be restored to health as much as possible, and connectivity between Takapūwähia and Te Awarua o Porirua will be improved for the community. "Future generations will be enabled to interact with the harbour in traditional ways"2

The natural environment within the community will be preserved and enhanced wherever possible. Takapüwähia will return to a self-sufficient and self-reliant community.

The cultural and environmental history of Takapüwähia and Te Awarua o Porirua Harbour will be preserved and retold from a Ngāti Toa Rangatira perspective. This viewpoint should also be reflected in all PCC public documents containing historic or cultural information

Above Fig 150. Ngāti

Toa Vision Statement

(Takapūwāhia Community

Strategy 2014, Page 13).
Whilst not public transport, it is also of note that the rail line parallel to State Highway 1 also operates as the main freight line to/from Wellington, and as such removes significant volumes of freight from State Highway 1 and possibly Porirua, each year.

Bus Network

Public bus services are provided by Mana Coach Services under subsidy from GWRC Services primarily provide connectivity between Porirua East, Whitby, Titahi Bay and the central city / railway station, with some services operating to/from the Wellington CBD (but not beyond). (Refer Figure 4.1.)

\section{Opportunities}

The statistical information presented in Section 2, and feedback from the consultation exercise identify a number of core issues which provide the rationale for public transportation in Porirua:

- $75 \%$ of trips made are by motor vehicle, one third of these trips are under $2 \mathrm{kms}$ in length and two-thirds are less than $6 \mathrm{kms}$ many of these trips could be made by public transport, walking and cycling (New Zealand Travel Survey);

- walking accounts for $20 \%$ of all household travel trips, and $25 \%$ of walking trips are made by children, young people and seniors reflecting the lack of access to a car (NZTS);

- an ageing population, in which mobility provision through walking facilities will become increasingly important;

- low levels of vehicle ownership in some parts of the City;

- access by public transportation to new development areas (for example, Aotea Block);

- need to improve bus/rail interchange facilities (accessibility, standard);

- the needs of the mobility-impaired;

- the need for all suburban centres to have easy and safe walking/cycling access to the Porirua CBD and public transportation routes;

- the need to minimise east-west severance arising from State Highway 1 and the railway line;

- the possibility of direct bus services between Porirua and the Wellington city centre;

- the efficiency of school bus services in rural areas; and

- the adequacy of 'park \& ride' facilities at railway stations.

Above Fig 151. Publi

Transport Porirua (PCC, Porirua

Transportational Strategy, 2012

Page 35) 

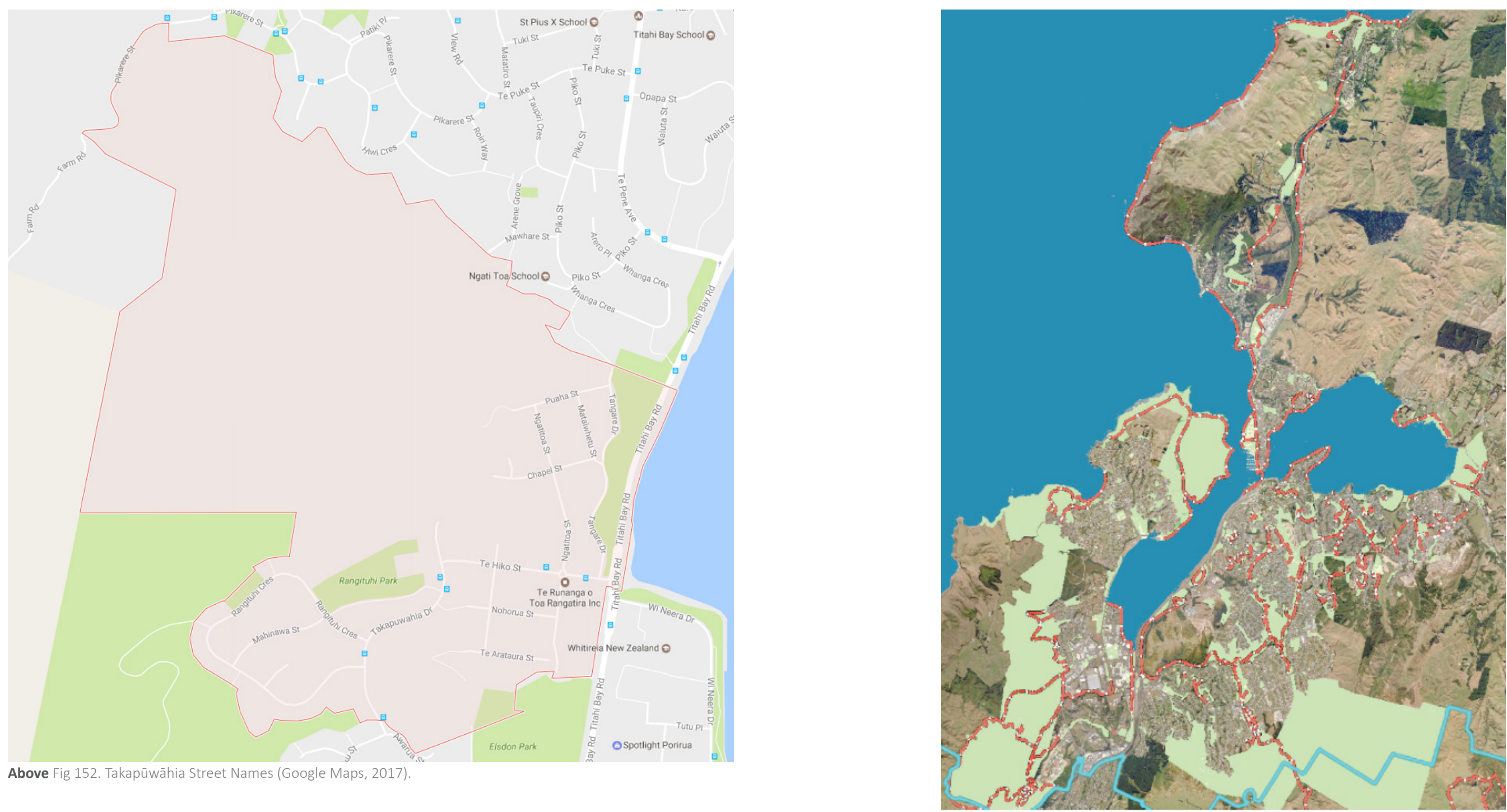

Above Fig 153. Porirua Network

(PCC Recreation + Open Space

KEY:

Strategy, 2012, Page 21).

Parks

- Recreation Pathways 


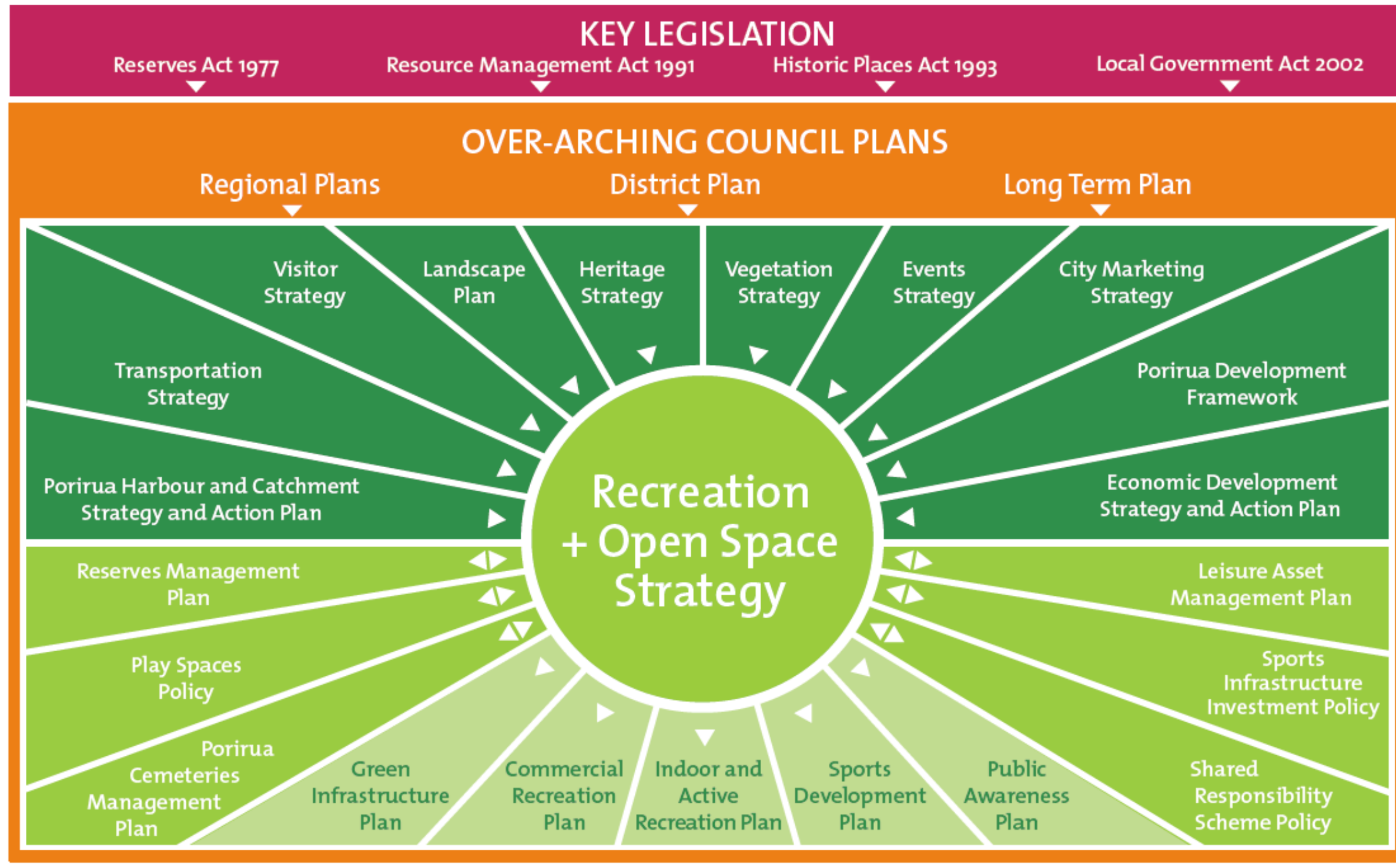

KEY: Council Strategies, Frameworks and Plans

Leisure Asset Plans and Policies

Proposed Plans

Above Fig 154. Strategy Context

(PCC, Recreation + Open Space

Strategy, 2012, Page 5). 


\begin{tabular}{|c|c|c|c|}
\hline Characteristics & Western science & Citizen science & TEK \\
\hline Goals & $\begin{array}{l}\text { Seeking universals and testing } \\
\text { theories throushe experiments, the } \\
\text { analysis of data, and models }\end{array}$ & $\begin{array}{l}\text { Offering local data to those seeking } \\
\text { universals and te sting theories }\end{array}$ & $\begin{array}{l}\text { Usually offering data and pattern } \\
\text { analysis specific to or bounded by a } \\
\text { culturally defined space and time }\end{array}$ \\
\hline Participants & $\begin{array}{l}\text { Largely done by academically trained } \\
\text { professionals and technicians, some } \\
\text { of them naturalists }\end{array}$ & $\begin{array}{l}\text { Largely done by enlieghtened/ } \\
\text { comminted amateurt naturalists, } \\
\text { often trained in other professions }\end{array}$ & $\begin{array}{l}\text { Largely done by "proto-professional" } \\
\text { naturalists: foragers, huntersi, } \\
\text { fishers, farmers, and shamans }\end{array}$ \\
\hline Communication & $\begin{array}{l}\text { Primarily transmitted through written } \\
\text { works, graphs, and formal oral } \\
\text { presentations }\end{array}$ & $\begin{array}{l}\text { Primarily transmitted through } \\
\text { field notes, social media, online } \\
\text { databases and informal oral } \\
\text { presentations }\end{array}$ & $\begin{array}{l}\text { Primanily transmitted orally in an } \\
\text { indigenous language and also } \\
\text { through song, story, maps, and art }\end{array}$ \\
\hline Framework & $\begin{array}{l}\text { Done by indididuals, small teams, or } \\
\text { cybernetworks for universal benefit }\end{array}$ & $\begin{array}{l}\text { Done for pleasure by individuals or } \\
\text { cohorts of volunteer participants in } \\
\text { informal networks often guided by } \\
\text { professionals }\end{array}$ & $\begin{array}{l}\text { Done in multigenerational } \\
\text { communuities primarily for the } \\
\text { community }\end{array}$ \\
\hline Worldview & $\begin{array}{l}\text { In most cases, wary of spirtual } \\
\text { dimensions and ambivalent on the } \\
\text { ethical-moral context }\end{array}$ & $\begin{array}{l}\text { Variable in directly addressing } \\
\text { spiritual, moral, and ethical } \\
\text { dimensions, depending on the } \\
\text { community }\end{array}$ & $\begin{array}{l}\text { Seamlessly linked to spiritual } \\
\text { dimensions and ethical-moral } \\
\text { considerations }\end{array}$ \\
\hline Methodological concerns & $\begin{array}{l}\text { Insists on separation of object- } \\
\text { subject }\end{array}$ & $\begin{array}{l}\text { Ambivalent on object-subject } \\
\text { dichotomy }\end{array}$ & Less object-subject dichotomy \\
\hline Location/Scale & $\begin{array}{l}\text { Increasingly done irrespective of } \\
\text { place or focused on model systems }\end{array}$ & $\begin{array}{l}\text { Preferably affectionately done as } \\
\text { place-based inquiry }\end{array}$ & $\begin{array}{l}\text { Embedded in cultural cosmology } \\
\text { specific to place }\end{array}$ \\
\hline
\end{tabular}

Above Fig 155. A

comparison of Features

(Wilder, O'Meara, Monti,

\& Nabhan, 2016, Page 3).

\section{Hukatai Stream - Wetland System at Takapūwähia}

Reserve

Overoiezo

Hukatai Stream is in a stage of severe degradation. However, some fish populations continue to live in the stream however. The area of stream at

Takapūwāhia Reserve has been identified as an area where significant ecological restoration can occur.

Due to the many constraints placed on the Onepoto Arm of Te Awarua 0 Porirua Harbour the potential for significant restoration at areas of the shoreline is severely limited. State Highway 1 stretches along the western length of the inlet while the eastern and southern sides are likewise constrained by the Titahi Bay Main Road and Porirua CBD. These developments are situated primarily on land reclaimed from the original

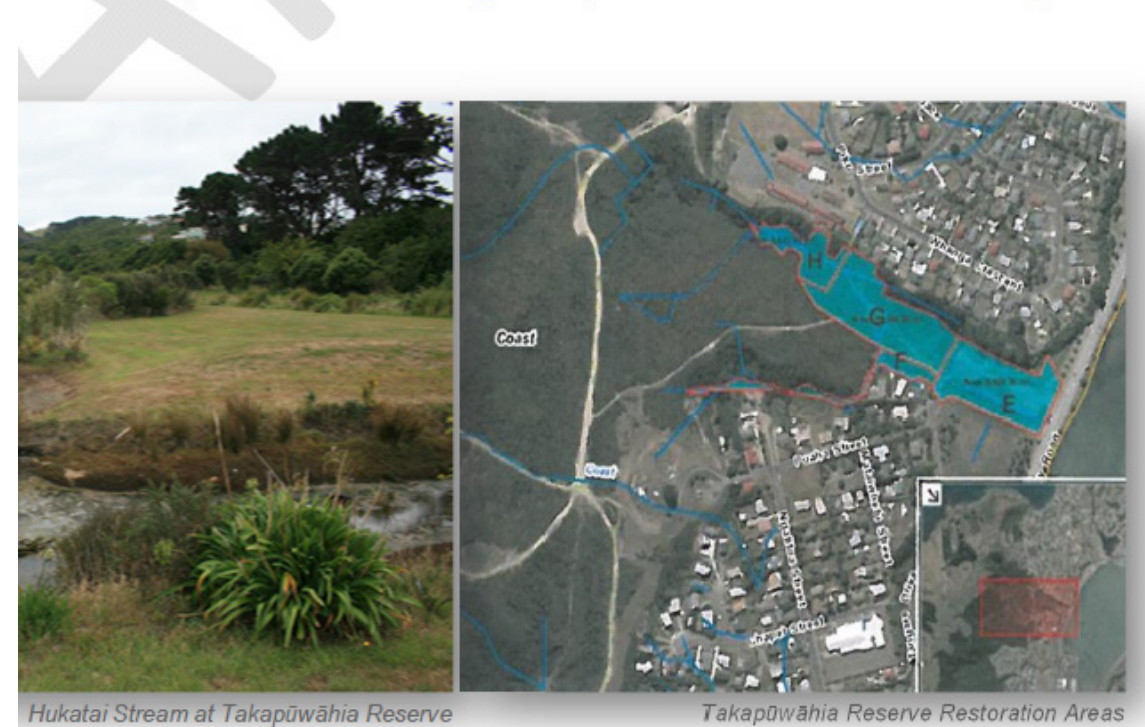

Above Fig 156. Wetland System (Takapūwāhia

Community Strategy 2014, Page 19). 


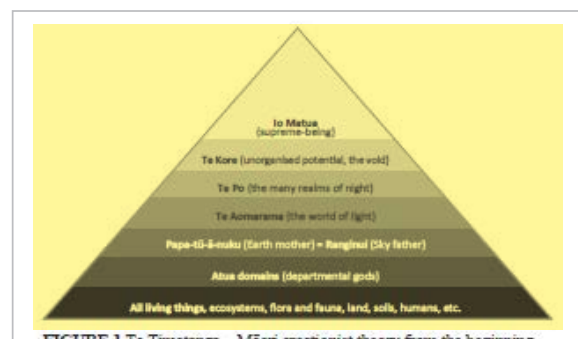

FGGRE 1 Te Timatanga - Maori creanionist theory from the beginning In a plan carried out by the children to create light and flourish.
the parents were prised apart. The separation of the parents led to Ranginui (the Sky father) forming the sky, resulting in the rain as he continued to weep for his separated wife Papa-ti-a-a-
muku (the Earth mother), and Papa-ti-a--nulu forming the land to provide sustained nourishment for all her children. As part of this ancesty, a large number of responsiblitites and obligaton of people, communities, and natural resources

It is within this context of cosmology and knowledge that Märi can form a perspective of ecosystems and ecosystem services and make sense of existing and emergng non-Mäon scientific and ecological terms, concepts and knowledge forms. Maon language and oral tadition are imperative in unlocking tive, therefore, an understanding of ecosystems starts with Menor language translation and whakapapa

MĀTAURANGA MĀORI

Mātauranga Mãoni (Barlow 1993; Dunie 1998; Harmsworth 1998; Hamsworth et al. 2002, Mead 2003; Wattang Inbunal 20rspective ens the basis for the Mong world view and is a ophy, beliefs, language, methods, technology and practice There are mumerous definitions of mâtauranga Māori. One of the more generally accepted is Marsden's (1988), which defines it, in a traditional context, as "the knowledge, comprehension or understanding of every ling visiole or misisle that exists across the universe, tiis includes all Maon knowledge systems or ways of moring beyoud the strictly tontivonl (ie locked in the post).

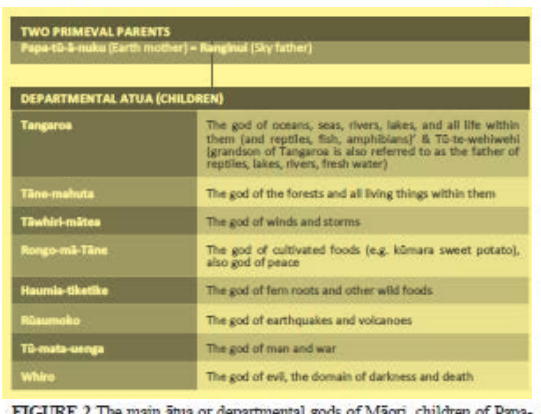

gods of Märn, childten of Papp-

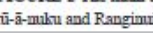

mātauranga Māori has grown into many contemporary forms (e.g. histoncal, local and regional indigenous hnowledge (e.

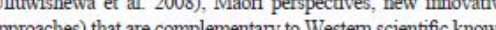
dge; a view consistent with many recent Māoni authors wib regard Māor knowledge as a dynamic and evolving knowledge form that represents more than the past (Harmsworth 1997; Dune 1998; Harmssworth et al 2002, 2011; Morgan 2003, 20066, 2007,

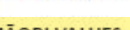

Māori values (Henare 1988, 2001; Marsden 1988: Marscen and Henare 1992; Barlow 1993; Harmsworth 1997; Mead 2003) are denved from the tradition Măori. Values can be defined as instruments through which Mani make sense of, experience, and interpet their enironmet (n)

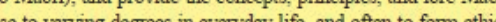
and principles. This can govem responsibilities and the relationhips Maon have with the environment and the way they ma. decisions. Important Māori values (see glossary) include: tikang (customary practice, values, protocols); whakapapa (ancestris ineage, genealogical connections, relationships, inks to ecosys(uns), fio rangatitanga (self-detemination); mana when

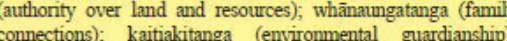
manaakitanga (acts of giving and caring for); whakkakotahitang consensus, respect for individual differences and participator mclusion for decision-making); arohatanga (the notion of care, respect, love, compassion); wairuatanga (a spintual dimension) Maon values can therefore be transtated into, and provide a bass conturt of what is significant and how to prioritise values (i.e. among naturar resources, solls, siguificant cultural sites, sigunificant biodiver sty habitats and species, iconic cultural plant and animal species).

KEY MĀORI ENVIRONMENTAL CONCEPTS

The Mãori values listed above underlie important Mãori envi1993; Durie 1994; Kawharu 2000; Harmsworthen al 2002; Mea 2003; Awatere et al 2011) and form the basis for Mãori perspectives when seeking to assess and understand ecosystems. Some of the key environmental concepts are:

Whakapapa - comection, lineage, or genealogy between humans and ecosystems and all flora and fauma. Mäori seel to understand the total environment or whole system and systems, and their perspective today is holistic and integrated Kaitakitanga - stewardship or guardianship of the environment, an active rather than passive relationship (Marsden and Henare 1992; Roberts et al. 1995)

Mana - having authority or control over the management of natural resources

- whole-of-landscape approach, understanding and mannging interconnected resources and ecosystems from
the mountains to the sea (the Mãori concept of integrated catchment management)

Taonga tulu hu ho-intergenerational protection of highly valued taonga, passed on from one generation to the next, in a caring and respectful mamer

Above Fig 157. Traditional Knowledge and

Beliefs (Harmsworth and Awatere, Page 275).

\begin{tabular}{|c|c|c|c|}
\hline Outcome classes & Outcome goals & Indicators & Examples \\
\hline \multirow[t]{2}{*}{ 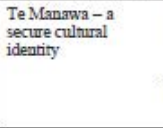 } & $\begin{array}{l}\text { Positive Maori participation in } \\
\text { scciery as Marori }\end{array}$ & 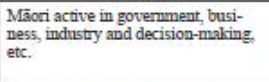 & 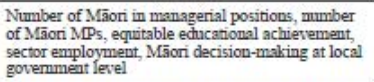 \\
\hline & $\begin{array}{l}\text { Positive Mäori participation in Mäori } \\
\text { sociery }\end{array}$ & $\begin{array}{l}\text { Mäori active in their commnnmities, } \\
\text { whănanu marae }\end{array}$ & 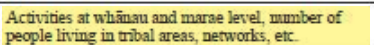 \\
\hline \multirow[t]{3}{*}{$\begin{array}{l}\text { Te Kähui-collective } \\
\text { Mâori synergies }\end{array}$} & Vibrant Mäori conmumities & 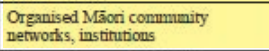 & $\begin{array}{l}\text { Märi conmumity standerds of living, number of } \\
\text { marae \& c conätion }\end{array}$ \\
\hline & Enhanced Whänau capaccities & Strong and supportive fanulles & Levels of Märi well-being \\
\hline & 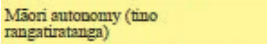 & Mäori practising self-determination & 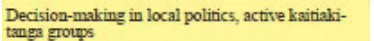 \\
\hline \multirow[t]{2}{*}{ 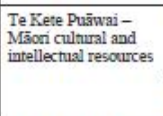 } & Te reo Mäori in nuliple domains & Lrcressed use of Măori langugage & $\begin{array}{l}\text { Nimber of fluent Miarori speakes by iwi and nation- } \\
\text { ally, use of te reo Majori in sociery }\end{array}$ \\
\hline & $\begin{array}{l}\text { Parctice of Mäori culture hrowledge, } \\
\text { and values }\end{array}$ & $\begin{array}{l}\text { Maori values and matanurangaga Mäori } \\
\text { being used across instintions }\end{array}$ & $\begin{array}{l}\text { Maori knoviledge systems developed and being } \\
\text { regulariy used }\end{array}$ \\
\hline \multirow[t]{4}{*}{$\begin{array}{l}\text { Te Ao Turoa - the } \\
\text { Mario estate }\end{array}$} & Regeneratad Măori land basse & Area of Maori land and resourres & Märi registered land area quaunified \\
\hline & $\begin{array}{l}\text { Guarauteed Mäori access to clean } \\
\text { and bealthy enviroument }\end{array}$ & 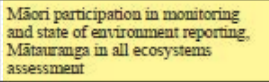 & 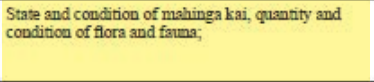 \\
\hline & & & abumdance preseace abseace of taonga species \\
\hline & $\begin{array}{l}\text { Resource sustainabblity and } \\
\text { accessibility }\end{array}$ & 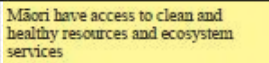 & $\begin{array}{l}\text { State and condition of nantral resources in tribal } \\
\text { areas }\end{array}$ \\
\hline
\end{tabular}

TABLE 4 An ecosystem services classification frmmework of provisioning, regulating, cultural and supporting services showing the 33 main service sub-

\begin{tabular}{|c|c|c|}
\hline & & \\
\hline \multirow{6}{*}{$\begin{array}{l}\text { Total value of } \\
\text { cecosystem services }\end{array}$} & \multirow[t]{2}{*}{ Direct use values } & Provisioning services \\
\hline & & $\begin{array}{l}\text { Regulating services } \\
\text { Cultral services }\end{array}$ \\
\hline & $\begin{array}{l}\text { Indirect use } \\
\text { values }\end{array}$ & 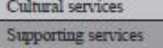 \\
\hline & \multirow[t]{3}{*}{ Passine talues } & Option values \\
\hline & & $\begin{array}{l}\text { Existence values } \\
\end{array}$ \\
\hline & & Bequest values \\
\hline
\end{tabular}

Above Fig 158. Māori outcome goals and classes (Harmsworth and Awatere, Page 280) 


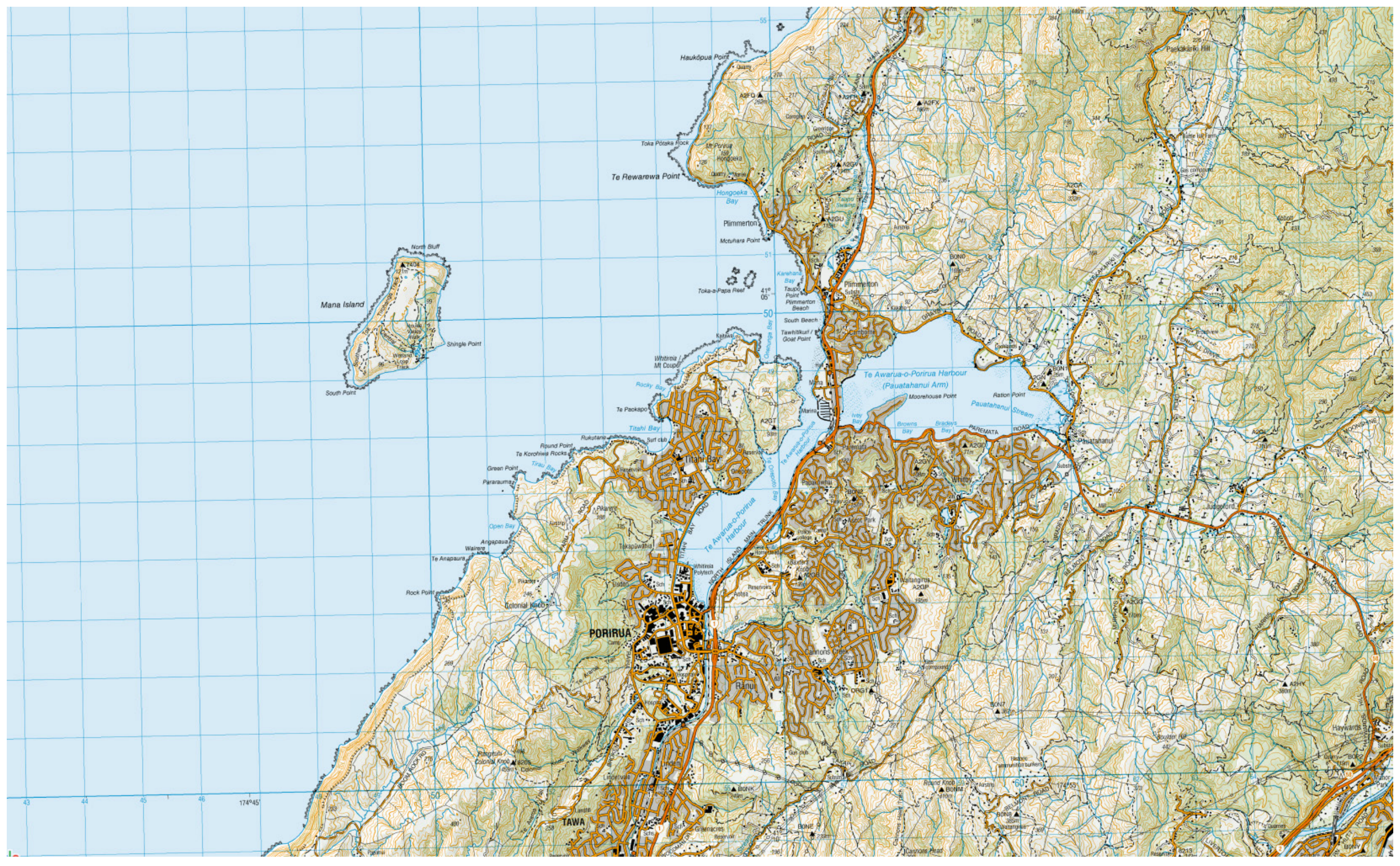

Above Fig 159. Porirua Regional Topo Map (NZ Topo Map, 2017). 
h Takapuwahia Trees Map Data share Report To CSV

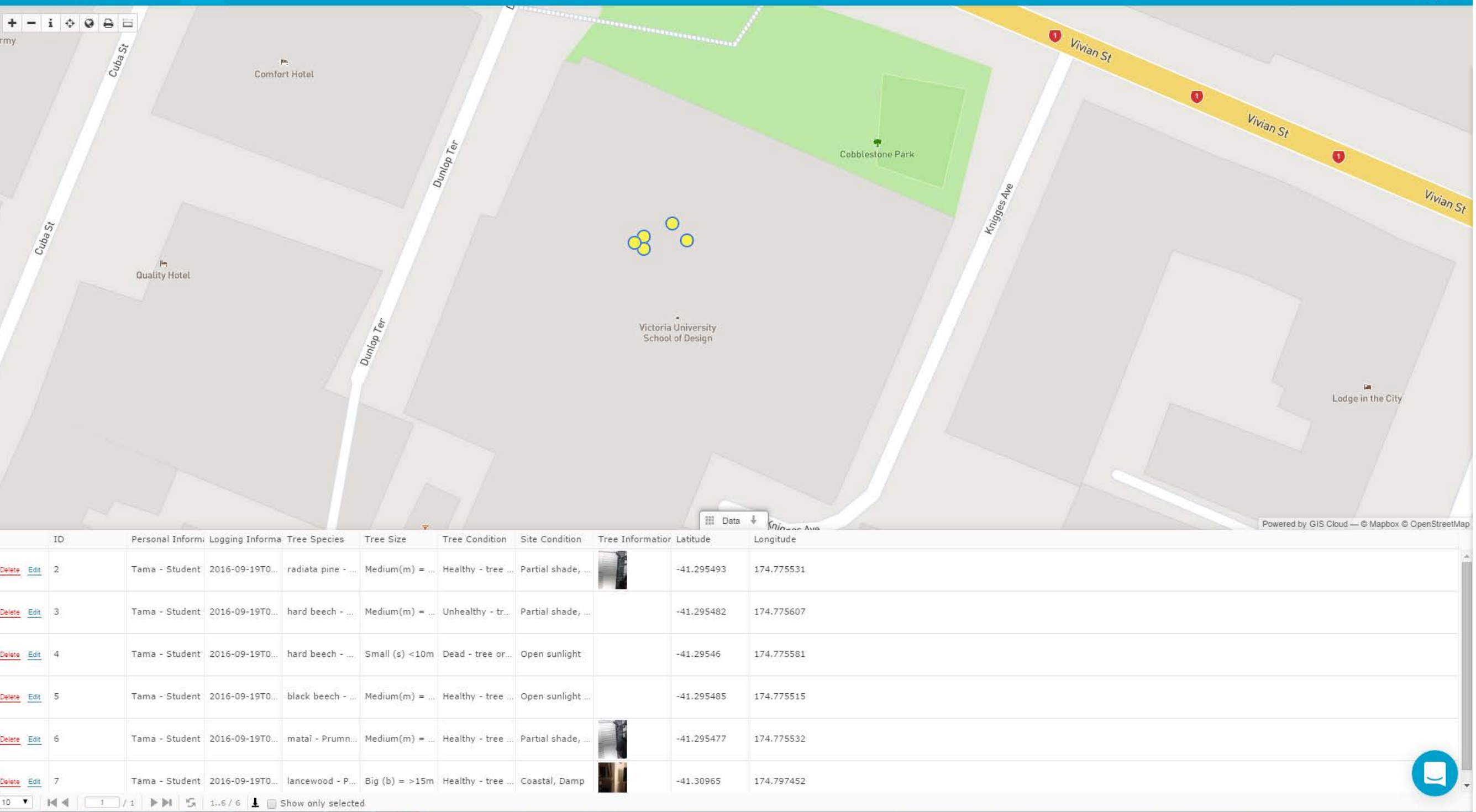




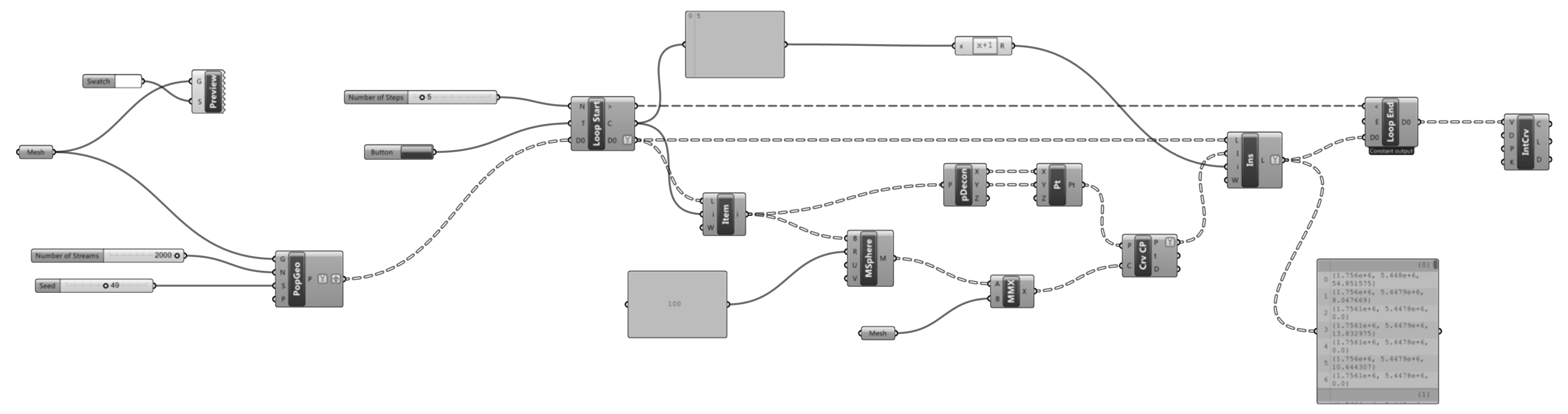

WATER RUNOFF SCRIPT

Above Fig 161. Water Runoff Script (Authors 


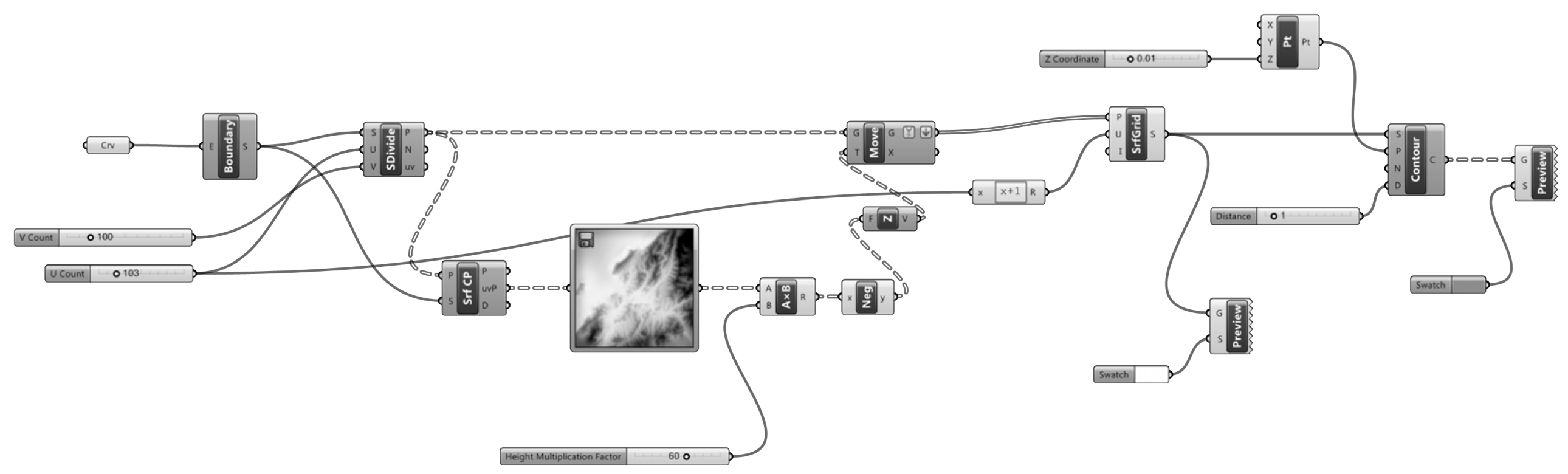

HEIGHTMAP SURFACE SCRIPT

Above Fig 162. Heightmap Surface Script

(Authors own) 


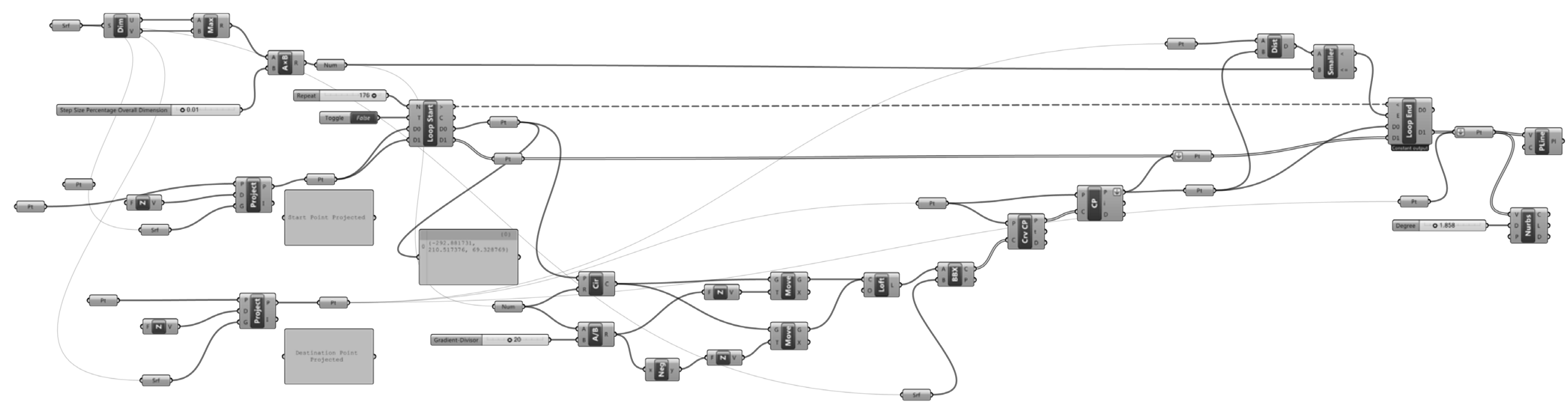

PATHFINDER SCRIPT

Above Fig 163. Pathfinder Script (Authors own) 
